UNIVERSIDADE DE SÃO PAULO

ESCOLA DE COMUNICAÇÕES E ARTES

Luciana Hiromi Yamada da Silveira

\title{
Modelo de caracterização de infográficos \\ Uma proposta para análise e aplicação jornalística
}





\section{Modelo de caracterização de infográficos Uma proposta para análise e aplicação jornalística}

Dissertação apresentada à Escola de Comunicações e Artes da Universidade de São Paulo para obtenção do título de Mestre em Ciências da Comunicação.

Área de Concentração: Estudo dos Meios e da Produção Mediática

Orientador: Prof. Dr. José Coelho Sobrinho 
Silveira, Luciana Hiromi Yamada da

Modelo de caracterização de infográficos: uma proposta para análise e aplicação jornalística / Luciana Hiromi Yamada da Silveira. - São Paulo: L. H. Y. Silveira, 2010. 175 p.

Dissertação (Mestrado) - Departamento de Jornalismo e Editoração/Escola de Comunicações e Artes/USP.

Orientador: Prof. Dr. José Coelho Sobrinho.

Bibliografia

1. Comunicação visual 2. Jornalismo 3. Design gráfico 4. Linguagem jornalística 5. Análise de conteúdo I. Coelho Sobrinho, José II. Título.

CDD 21.ed. - 070

Autorizo a reprodução e divulgação total ou parcial deste trabalho, por qualquer meio convencional ou eletrônico, para fins de estudo e pesquisa, desde que citada a fonte. 


\section{FOLHA DE APROVAÇÃO}

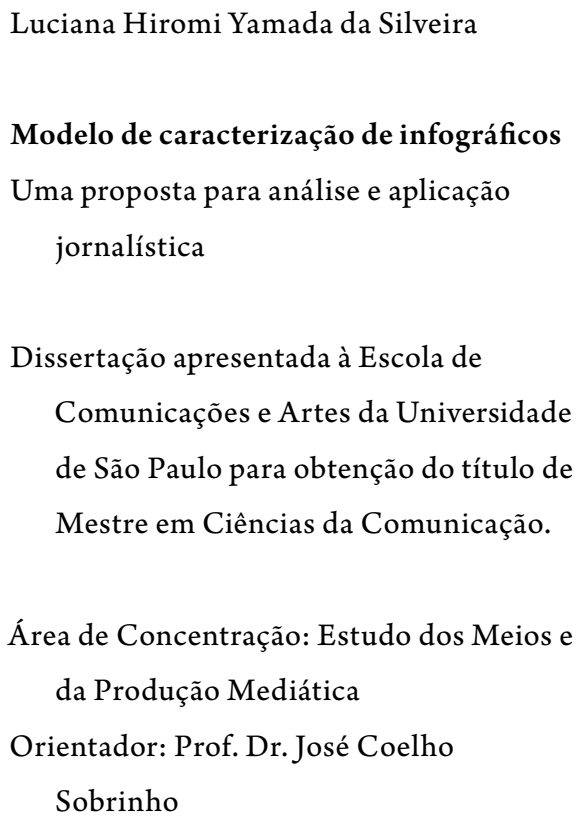

Aprovado em:

\section{Banca Examinadora}

Prof. Dr.

Instituição:

Assinatura:

Prof. Dr.

Instituição:

Assinatura:

Prof. Dr.

Instituição:

Assinatura: 

Dedicatória

Aos jormats de 2001

Aos jormats e jornots

de 2007 e 2008 

Ao professor José Coelho Sobrinho, pela orientação e pelo incentivo.

À Capes, pela concessão de bolsa de mestrado para o desenvolvimento do trabalho.

À biblioteca da ECA e às secretarias de pós-graduação da ECA e do CJE, pela ajuda sempre providencial.

À minha família: meus pais Roque e Lúcia, minha irmã Leda, meu irmão Lauro e minha cunhada Anapaula - todos responsáveis por manter o estresse em níveis aceitáveis.

Aos amigos Lígia, Liuca, Marcela, Naila, Gustavo, Jonathan, Juliano e Shimizu - incluídos à força em minha segunda passagem ecana. 

SILVEIRA, Luciana Hiromi Yamada da. Modelo de caracterização de infográficos: uma proposta para análise e aplicação jornalística. 2010. 175 p. Dissertação (Mestrado) - Escola de Comunicações e Artes, Universidade de São Paulo, São Paulo, 2010.

O infográfico é uma ferramenta jornalística marcada pela quebra da linearidade do texto escrito e pela organização gráfica do conteúdo, com o objetivo de promover interesse e compreensão. Nos últimos anos, diagramas menos ilustrativos e mais analíticos vêm marcando um período de mudanças em sua produção. Esta pesquisa propõe um modelo para caracterização e avaliação de infográficos em contextos acadêmicos e jornalísticos, com a finalidade de orientar sua produção. O modelo foi testado como guia de análise de conteúdo, gerando conjunto de dados sobre o uso do recurso em veículos noticiosos brasileiros.

Palavras-chave: Comunicação visual. Jornalismo. Design gráfico. Linguagem jornalística. Análise de conteúdo. 

SILVEIRA, Luciana Hiromi Yamada da.

Characterization model for infographics: a proposal for analysis and application to journalism. 2010. 175 p. Dissertation (Master's degree) - Escola de Comunicações e Artes, Universidade de São Paulo, São Paulo, 2010.

Infographics are journalistic tools distinguished by the non-linearity of the written text and the graphic organization of its content, aiming to increase the reader's interest and understanding. In recent years infographics prioritizing analysis over decoration have been signalizing a transitional period in its production. This research proposes a model for characterization and evaluation of infographics for both academic and journalistic contexts, seeking to aid its production. The model has been tested as codebook for content analysis, generating data regarding their usage in Brazilian newspapers and magazines.

Keywords: Visual communication. Journalism. Graphic design. Journalistic language. Content analysis. 



\section{LISTA DE FIGURAS}

\begin{tabular}{|c|c|c|c|}
\hline & Página & Título ou descrição & Fonte \\
\hline Fig. 2-1 & 22 & Um jogo comunicativo & $\begin{array}{l}\text { Produzido por Luciana Silveira; ícones do item } 1 \text { utilizam a } \\
\text { fonte Little Big Man (www.fontenvironment.com) }\end{array}$ \\
\hline Fig. 2-2 & 26 & $\begin{array}{l}\text { Do alfabeto fenício ao } \\
\text { latino }\end{array}$ & $\begin{array}{l}\text { Adaptado de Evolution of Alphabets, de Robert Fradkin - } \\
\text { University of Maryland (www.terpconnect.umd.edu/ } \\
\sim \text { rfradkin/alphapage.html) }\end{array}$ \\
\hline Fig. 2-3 & 28 & $\begin{array}{l}\text { Bibliae pauperum holandesa } \\
\text { do século } 15\end{array}$ & $\begin{array}{l}\text { Extraído da capa de The Bible of the Poor (facsimile de bibliae } \\
\text { pauperum do século 15), de Labriola e Smeltz }\end{array}$ \\
\hline Fig. $2-4$ & 31 & Blissymbolics & $\begin{array}{l}\text { Adaptado de Lesson One: An Introduction to Blissymbols, de } \\
\text { Douglas Crockford (www.blissym.com) }\end{array}$ \\
\hline Fig. 2-5 & 31 & IsOTYPE & $\begin{array}{l}\text { Traduzido de diagrama de Twyman (1975) adaptado em Otto } \\
\text { Neurath e o legado do Isoty PE (InfoDesign Revista Brasileira } \\
\text { de Design da Informação 5), de Ricardo Cunha Lima }\end{array}$ \\
\hline Fig. 2-6 & 32 & Movimentos sacádicos & $\begin{array}{l}\text { DOVES: A Database of Visual Eye Movements, Laboratory for } \\
\text { Image \& Video Engineering - University of Texas } \\
\text { (http://live.ece.utexas.edu/research/doves) } \\
\text { e } \\
\text { The science of word recognition, de Kevin Larson } \\
\text { (www.microsoft.com/typography/ } \\
\text { ctfonts/WordRecognition.aspx) }\end{array}$ \\
\hline Fig.2- 7 & 33 & Homúnculo de Penfield & $\begin{array}{l}\text { Reprodução de The cerebral cortex of man: a clinical study of } \\
\text { localization offunction, de Penfield e Rasmussen }\end{array}$ \\
\hline Fig. 2-8 & 34 & $\begin{array}{l}\text { As vias do sistema de } \\
\text { percepção visual }\end{array}$ & Adaptado de Ramachandran (2002) \\
\hline Fig. 2-9 & 36 & Árvore da Vida & $\begin{array}{l}\text { Reprodução de pôster da BBC/The Open University } \\
\text { (www.open2.net/darwin/poster.html) }\end{array}$ \\
\hline Fig. 3-1 & 40 & O papel do jornal & $\begin{array}{l}\text { Reprodução de pôster criado por Pedro Monteiro } \\
\text { (www.whatype.wordpress.com/2009/03/02/ } \\
\text { the-end-of-print-we-think-not/) }\end{array}$ \\
\hline Fig. 3-2 & 43 & Leituras medidas & $\begin{array}{l}\text { Adaptado de gráfico de Mário Kanno (2008), com dados do } \\
\text { Instituto Poynter (2007) }\end{array}$ \\
\hline Fig. 3-2 & 44 & A TV no jornal impresso & Foto de www.flickr.com/photos/nimbupani/1389798942/ \\
\hline Fig. 3-3 & 45 & A informação visual & $\begin{array}{l}\text { Reprodução de primeira página do jornal } \\
\text { The Independent (21/jul./2006) }\end{array}$ \\
\hline
\end{tabular}




\begin{tabular}{|c|c|c|c|}
\hline & Página & Título ou descrição & Fonte \\
\hline Fig. 4-1 & 49 & Exportações e importações & $\begin{array}{l}\text { Traçado de Spence e Weiner (2005) sobreposto a gráfico de } \\
\text { Playfair (1801); reprodução colorida extraída de errata digital } \\
\text { (www.psych.utoronto.ca/ users/spence/Research_WP.html) }\end{array}$ \\
\hline Fig. 4-2 & 50 & Percepção gráfica & Adaptados de Cleveland (1994) \\
\hline Fig. 4-3 & 51 & Chart junk & Extraído de Tufte (2007) \\
\hline Fig. 4-4 & 52 & Tratamento de dados & Extraído de Bertin (1986) \\
\hline Fig. 4-5 & 53 & $\begin{array}{l}\text { O que é preciso para ser um } \\
\text { designer da informação? }\end{array}$ & Tradução de ilustração de Holmes para Heller (2006) \\
\hline Fig. 4-6 & 54 & Como o leitor lê & $\begin{array}{l}\text { Extraído de Mário Kanno (2008), com dados do Instituto } \\
\text { Poynter (2007) }\end{array}$ \\
\hline Fig. 5-1 & $61-70$ & História da infografia & $\begin{array}{l}\text { Produzido por Luciana Silveira; ver Lista complementar de } \\
\text { figuras para créditos de imagens }\end{array}$ \\
\hline Fig. 5-2 & 71 & $\begin{array}{l}\text { Público e graus de } \\
\text { abstração }\end{array}$ & $\begin{array}{l}\text { Colagem com gráfico oficial do CERN e infográfico da revista } \\
\text { New Scientist (set./2008) }\end{array}$ \\
\hline Fig. 5-3 & 72 & Ilusão de óptica & Extraído de Ramachandran (2002) \\
\hline Fig. 5-4 & 75 & A regra $<6><6>$ & Traduzido de Roam (2008) \\
\hline Fig. 5-5 & 77 & $\begin{array}{l}\text { A infografia analítica em } \\
\text { The New York Times } \\
\text { (og/nov./2006) }\end{array}$ & Reprodução de página do jornal \\
\hline Fig. 6-1 & 80 & Modelo tipológico & Adaptado de Teixeira (2007) \\
\hline Fig. 6-2 & 83 & A fórmula tripartida & Adaptado de Mijksenaar (1997) \\
\hline Fig. 6-3 & 84 & Informação e design & Traduzido de McCandless (2009) \\
\hline Fig. 6-4 & 91 & O fim da Aids? & Reprodução de página da revista Galileu (abr./2009) \\
\hline
\end{tabular}




\section{LISTA COMPLEMENTAR DE FIGURAS}

\begin{tabular}{|c|c|c|c|}
\hline & Página & Título ou descrição & Fonte \\
\hline Fig. 5-1.1 & 61 & $\begin{array}{l}\text { "March of progress" } \\
\text { (evolução humana) }\end{array}$ & $\begin{array}{l}\text { Reprodução de ilustração de F. Clark Howell para a série LIFE } \\
\text { Nature Library (1965) }\end{array}$ \\
\hline Fig. 5-1.2 & 61 & Pinturas pré-históricas & Retirado de EuroPreArt (www.europreart.net) \\
\hline Fig. 5-1.3 & 61 & Tábuas de Tărtăria & $\begin{array}{l}\text { Reprodução de ilustração adaptada de Vassar (autoria } \\
\text { desconhecida) }\end{array}$ \\
\hline Fig. 5-1.4 & 61 & $\begin{array}{l}\text { Mapa ucraniano (c.10.00o } \\
\text { a.C.) }\end{array}$ & $\begin{array}{l}\text { Reprodução de imagem do EMuseum - Minnesota State } \\
\text { University (www.mnsu.edu/emuseum/) }\end{array}$ \\
\hline Fig. 5-1.5 & 61 & Mapa turco (6200 a.C.) & $\begin{array}{l}\text { Extraído de Milestones in the History of Thematic } \\
\text { Cartography,Statistical Graphics, and Data Visualization, de } \\
\text { Friendly e Denis - York University (www.math.yorku.ca/ } \\
\text { SCS/Gallery/milestone) }\end{array}$ \\
\hline Fig. 5-1.6 & 62 & Alfabeto fenício & Adaptado de Higounet (2003) \\
\hline Fig. 5-1.7 & 62 & Alfabeto grego & Adaptado de Higounet (2003) \\
\hline Fig. 5-1.8 & 62 & $\begin{array}{l}\text { Mapa-múndi de } \\
\text { Anaximander de Mileto }\end{array}$ & $\begin{array}{l}\text { Extraído de Milestones in the History of Thematic } \\
\text { Cartography,Statistical Graphics, and Data Visualization, de } \\
\text { Friendly e Denis - York University (www.math.yorku.ca/ } \\
\text { SCS/Gallery/milestone) }\end{array}$ \\
\hline Fig. 5-1.9 & 62 & Alfabeto latino & Adaptado de Higounet (2003) \\
\hline Fig. 5-1.10 & 62 & $\begin{array}{l}\text { Diagrama de propriedades } \\
\text { euclideanas }\end{array}$ & $\begin{array}{l}\text { Fotografia do acervo do museu da University of Pennsylvania; } \\
\text { extraído de One of the oldest extant diagrams from Euclid, de } \\
\text { Bill Casselman - University of British Columbia } \\
\text { (www.math.ubc.ca/ cass/) }\end{array}$ \\
\hline Fig. 5-1.11 & 62 & $\begin{array}{l}\text { Mapa de disseminação da } \\
\text { escrita }\end{array}$ & Adaptado de Horcades (2004) \\
\hline Fig. 5-1.12 & 62 & $\begin{array}{l}\text { Ilustração de De materia } \\
\text { medica, de Dioscórides }\end{array}$ & $\begin{array}{l}\text { Reprodução de facsimile (1998) de manuscrito do ano 512; } \\
\text { o manuscrito pertence à Biblioteca Nacional da Áustria, em } \\
\text { Viena }\end{array}$ \\
\hline Fig. 5-1.13 & 63 & $\begin{array}{l}\text { Tábua de concordância do } \\
\text { Livro de Kells }\end{array}$ & $\begin{array}{l}\text { Reprodução de The Book of Kells - a hypertext work, de } \\
\text { Samantha Gorman (www.almitras.com) }\end{array}$ \\
\hline Fig. 5-1.14 & 63 & Escrita carolíngea & Extraído de Higounet (2003) \\
\hline Fig. 5-1.15 & 63 & $\begin{array}{l}\text { Diagrama do universo } \\
\text { segundo Macrobius }\end{array}$ & Reprodução de diagrama em domínio público \\
\hline Fig. 5-1.16 & 63 & Diagrama de astronomia & Extraído de Tufte (2007) \\
\hline
\end{tabular}




\begin{tabular}{|c|c|c|c|}
\hline & Página & Título ou descrição & Fonte \\
\hline Fig. 5-1.17 & 63 & $\begin{array}{l}\text { Mapa do Livro das } \\
\text { Curiosidades }\end{array}$ & $\begin{array}{l}\text { Reprodução de Biblioteca Bodleian - University of Oxford } \\
\text { (www.bodley.ox.ac.uk/bookofcuriosities) }\end{array}$ \\
\hline Fig. 5-1.18 & 64 & $\begin{array}{l}\text { Algarismos indo-arábicos } \\
\text { incorporados à escrita } \\
\text { europeia }\end{array}$ & $\begin{array}{l}\text { Reprodução de Histoire des Mathématiques, de Jean-Étienne } \\
\text { Montucla (1758) }\end{array}$ \\
\hline Fig. 5-1.19 & 64 & Bibliae pauperum & $\begin{array}{l}\text { Extraído da capa de The Bible of the Poor (facsimile de bibliae } \\
\text { pauperum do século 15), de Labriola e Smeltz }\end{array}$ \\
\hline Fig. 5-1.20 & 64 & Bíblia de Gutenberg & $\begin{array}{l}\text { Reprodução de cópia pertencente ao Harry Ranson Center } \\
\text { - University of Texas (www.hrc.utexas.edu/exhibitions/ } \\
\text { permanent/gutenberg/) }\end{array}$ \\
\hline Fig. 5-1.21 & 64 & Árvore das Afinidades & Extraído de Peltzer (1992) \\
\hline Fig. 5-1.22 & 64 & $\begin{array}{l}\text { De Humani Corporis } \\
\text { Fabrica }\end{array}$ & $\begin{array}{l}\text { Reprodução de Vesalius (1543); facsimile organizado por } \\
\text { Saunders e O’Malley (2003) }\end{array}$ \\
\hline Fig. 5-1.23 & 65 & Mapa-múndi de Mercator & Extraído de página da University of Essex (www.essex.ac.uk/) \\
\hline Fig. 5-1.24 & 65 & Theatrum Orbis Terrarum & $\begin{array}{l}\text { Extraído do site do museu Plantin-Moretus, na Antuérpia } \\
\text { (http://museum.antwerpen.be/plantin_moretus/) }\end{array}$ \\
\hline Fig. 5-1.25 & 65 & $\begin{array}{l}\text { Jornal holandês com } \\
\text { ilustrações }\end{array}$ & Extraído de Müller-Brockmann (2001) \\
\hline Fig. 5-1.26 & 65 & $\begin{array}{l}\text { Gráfico de longitude } \\
\text { (Toledo-Roma) }\end{array}$ & Extraído de Tufte (2007) \\
\hline Fig. 5-1.27 & 65 & $\begin{array}{l}\text { Mapa meteorológico de } \\
\text { Halley }\end{array}$ & Extraído de Tufte (2007) \\
\hline Fig. 5-1.28 & 66 & Mapa do Daily Courant & Extraído de Cairo (2008) \\
\hline Fig. 5-1.29 & 66 & Mapa do Daily Post & Extraído de Peltzer (1992) \\
\hline Fig. 5-1.30 & 66 & $\begin{array}{l}\text { Carte chronologique, de } \\
\text { Jacques Barbeu-Dubourg }\end{array}$ & $\begin{array}{l}\text { Extraído de Milestones in the History of Thematic } \\
\text { Cartography,Statistical Graphics, and Data Visualization, de } \\
\text { Friendly e Denis - York University (www.math.yorku.ca/ } \\
\text { SCS/Gallery/milestone) }\end{array}$ \\
\hline Fig. 5-1.31 & 66 & $\begin{array}{l}\text { Ilustração do Pennsylvania } \\
\text { Gazette }\end{array}$ & Extraído de De Pablos (1999) \\
\hline Fig. 5-1.32 & 66 & $\begin{array}{l}\text { Commercial and Political } \\
\text { Atlas }\end{array}$ & Extraído de Playfair (2005) \\
\hline Fig. 5-1.33 & 66 & Diagrama do Times & Extraído de Peltzer (1992) \\
\hline Fig. 5-1.34 & 67 & $\begin{array}{l}\text { Primeira página da } \\
\text { primeira edição da Gazeta } \\
\text { do Rio de Janeiro } \\
\text { (10/set./1808) }\end{array}$ & $\begin{array}{l}\text { Reprodução extraída de Revista de História da Biblioteca } \\
\text { Nacional (2008) }\end{array}$ \\
\hline Fig. 5-1.35 & 67 & $\begin{array}{l}\text { Fotografia de Niépce de } \\
1827 \text { (tentativas anteriores } \\
\text { não existem mais) }\end{array}$ & $\begin{array}{l}\text { Reprodução de LIFE: } 100 \text { Photographs that changed the world } \\
(2003)\end{array}$ \\
\hline
\end{tabular}




\begin{tabular}{|c|c|c|c|}
\hline & Página & Título ou descrição & Fonte \\
\hline Fig. 5-1.36 & 67 & $\begin{array}{l}\text { Mapa coroplético de } \\
\text { Guerry e Balbi }\end{array}$ & $\begin{array}{l}\text { Extraído de Milestones in the History of Thematic } \\
\text { Cartography,Statistical Graphics, and Data Visualization, de } \\
\text { Friendly e Denis - York University (www.math.yorku.ca/ } \\
\text { SCS/Gallery/milestone) }\end{array}$ \\
\hline Fig. 5-1.37 & 67 & $\begin{array}{l}\text { História ilustrada de } \\
\text { Töpffer }\end{array}$ & $\begin{array}{l}\text { Reprodução publicada em http://leonardodesa. } \\
\text { interdinamica.net/ comics/lds/vb/VieuxBoiso1.asp }\end{array}$ \\
\hline Fig. 5-1.38 & 67 & Código morse & Montagem própria do alfabeto latino em código morse \\
\hline Fig. 5-1.39 & 67 & Mapa estatístico de Minard & $\begin{array}{l}\text { Reprodução de Des chiffres et des cartes: la cartographie } \\
\text { quantitative au XIXè siècle, de Gilles Palsky }\end{array}$ \\
\hline Fig. 5-1.40 & 68 & $\begin{array}{l}\text { Layout de teclado } \\
\text { QWERTY }\end{array}$ & Reproduçao de patente de Christopher Sholes (1878) \\
\hline Fig. 5-1.41 & 68 & $\begin{array}{l}\text { Rascunho de tabela } \\
\text { periódica de Mendeleev }\end{array}$ & $\begin{array}{l}\text { Extraído de boletim do Instituto de Física da UFRGS } \\
\text { (www.ufrgs.br/) }\end{array}$ \\
\hline Fig. 5-1.42 & 68 & $\begin{array}{l}\text { Mapa meteorológico do } \\
\text { Times (15/abr./1875) }\end{array}$ & Extraído de Peltzer (1992) \\
\hline Fig. 5-1.43 & 68 & $\begin{array}{l}\text { Gráfico ilustrado de } \\
\text { Mulhall }\end{array}$ & $\begin{array}{l}\text { Extraído de Data Graphics, de Robert W. Glen - University of } \\
\text { Tennessee (http://web.utk.edu/ glenn/) }\end{array}$ \\
\hline Fig. 5-1.44 & 68 & Impressão off-set & Extraído de Finberg; Itule (1989) \\
\hline Fig. 5-1.45 & 69 & $\begin{array}{l}\text { Infográfico do New York } \\
\text { Times (o1/fev./1917) }\end{array}$ & Extraído de De Pablos (1999) \\
\hline Fig. 5-1.46 & 69 & $\begin{array}{l}\text { Capa da revista Survey } \\
\text { Graphic (jan./1938) }\end{array}$ & $\begin{array}{l}\text { Reprodução extraída de IsOTYPE Institute } \\
\text { (www.fulltable.com/iso/) }\end{array}$ \\
\hline Fig. 5-1.47 & 69 & Gráfico Isoty PE & Reprodução adaptada de Neurath e Arntz \\
\hline Fig. 5-1.48 & 69 & $\begin{array}{l}\text { Mapa de Henry Beck para } \\
\text { o metrô de Londres }\end{array}$ & Extraído do site da BBC (www.bbc.co.uk/) \\
\hline Fig. 5-1.49 & 69 & $\begin{array}{l}\text { Infográfico do jornal } \\
\text { Chicago Daily Tribune (1939) }\end{array}$ & Extraído de Finberg; Itule (1989) \\
\hline Fig. 5-1.50 & 69 & Blissymbolics & $\begin{array}{l}\text { Adaptado de Blissymbolics Communication International } \\
\text { (www.blissym.com) }\end{array}$ \\
\hline Fig. 5-1.51 & 69 & Diagramas - Arpanet & $\begin{array}{l}\text { Diagramas de Alex McKenzie extraídos de } \mathrm{W}_{3} \mathrm{C} / \mathrm{UK} \\
\text { (www.w3c.rl.ac.uk/) }\end{array}$ \\
\hline Fig. 5-1.52 & 70 & IBM $_{5150}$ & $\begin{array}{l}\text { Foto extraída de } \\
\text { http://en.wikipedia.org/wiki/File:IBM_original_PC.jpg }\end{array}$ \\
\hline Fig. 5-1.53 & 70 & Macintosh $128 \mathrm{~K}$ & $\begin{array}{l}\text { Foto extraída de http://en.wikipedia.org/wiki/ } \\
\text { File:Macintosh_128k_transparency.png }\end{array}$ \\
\hline Fig. 5-1.54 & 70 & USA Today (25/set./1982) & Reprodução de capa do jornal \\
\hline Fig. 5-1.55 & 70 & $\begin{array}{l}\text { Infográfico sobre Guerra } \\
\text { do Golfo - Folha de S. } \\
\text { Paulo (1991) }\end{array}$ & Extraído de Pereira (2006) \\
\hline Fig. 5-1.56 & 70 & $\begin{array}{l}\text { Infográfico premiado do } \\
\text { site do New York Times }\end{array}$ & Reprodução de gráfico interativo do site www.nytimes.com \\
\hline
\end{tabular}




\section{LISTA DE TABELAS}

\begin{tabular}{l|r|l} 
& \multicolumn{2}{|c|}{ Tágítulo ou descrição } \\
\hline Tab. 6-1 & 81 & Critérios de Independência \\
\hline Tab. 6-2 & $81-82$ & Critérios de Especificidade \\
\hline Tab. 6-3 & $85-86$ & Critérios de Integridade \\
\hline Tab. 6-4 & 87 & Critérios de Usabilidade \\
\hline Tab. 6-5 & $88-89$ & Critérios de Aparência \\
\hline Tab. 6-6 & $89-90$ & Critérios de Conteúdo \\
\hline Tab. 6-7 & $92-94$ & Exemplo de aplicação de modelo de caracterização \\
\hline Tab. 7-1 & 98 & Corpo de pesquisa \\
\hline Tab. 7-2 & 99 & Formulário de análise - identificação \\
\hline Tab. 7-3 & 100 & Formulário de análise - caracterização \\
\hline Tab. 7-4 & 100 & Exemplo de formulário de análise \\
\hline Tab. 7-5 & 107 & Eixos subordinado-independente e enciclopédico-específico (geral) \\
\hline Tab. 7-6 & 110 & Eixos subordinado-independente e enciclopédico-específico (revistas) \\
\hline Tab. 7-7 & 110 & Eixo estetizante-analítico (geral) \\
\hline Tab. 7-8 & 112 & Eixo estetizante-analítico (revistas) \\
\hline Tab. 7-9 & $114-115$ & Editorias \\
\hline
\end{tabular}




\section{LISTA DE GRÁFICOS}

\begin{tabular}{l|r|l}
\multicolumn{2}{|l}{ Página } & \multicolumn{2}{l}{ Título ou descrição } \\
\hline Grf. 7-1 & 101 & Representação gráfica de exemplo de aplicação de modelo \\
\hline Grf. 7-2 & 104 & Representação gráfica de resultados por edição - Agora São Paulo \\
\hline Grf. 7-3 & 104 & Representação gráfica de resultados por edição - Diário de São Paulo \\
\hline Grf. 7-4 & 105 & Representação gráfica de resultados por edição - O Estado de S. Paulo \\
\hline Grf. 7-5 & 105 & Representação gráfica de resultados por edição - Folha de S. Paulo \\
\hline Grf. 7-6 & 106 & Representação gráfica de resultados por edição - Jornal da Tarde \\
\hline Grf. 7-7 & 106 & Representação gráfica de resultados por edição - Época \\
\hline Grf. 7-8 & 107 & Representação gráfica de resultados por edição - Veja \\
\hline Grf. 7-9 & 108 & Representação gráfica dos eixos subordinado-independente e enciclopédico-específico \\
\hline Grf. 7-10 & 109 & Representação gráfica dos eixos subordinado-independente e enciclopédico-específico por \\
& 109 & Representação gráfica dos eixos subordinado-independente e enciclopédico-específico por \\
\hline Grf. 7-11 & 111 & Representação gráfica do eixo estetizante-analítico (jornais x revistas) \\
\hline Grf. 7-12 & 111 & Representação gráfica do eixo estetizante-analítico por título (jornais) \\
\hline Grf. 7-13 & 112 & Representação gráfica do eixo estetizante-analítico por título (revistas) \\
\hline Grf. 7-14 & 113 & Representação detalhada do eixo estetizante-analítico \\
\hline Grf. 7-15 & $115-116$ & Representação gráfica do eixo estetizante-analítico por editoria \\
\hline Grf. 7-16 & Representação gráfica de variação temporal (jornais e revistas) \\
\hline Grf. 7-17 & & título (revistas) \\
\hline
\end{tabular}





\section{SumÁRIO}

\begin{tabular}{|c|c|}
\hline \multirow{2}{*}{\multicolumn{2}{|c|}{ 2 Introdução }} \\
\hline & \\
\hline 2.1 Comunicação e sentidos & 23 \\
\hline 2.1.1 Sistemas de escrita & 24 \\
\hline 2.1.2 A reprodução da imagem & 27 \\
\hline 2.1.3 Palavras e imagens & 29 \\
\hline 2.2 Aspectos fisiológicos e cognitivos & 30 \\
\hline 2.3 Narrativas & 35 \\
\hline 3 Estilo no jornalismo & 37 \\
\hline 3.1 O papel do jornalismo hoje & 37 \\
\hline 3.2 O estilo jornalístico & 39 \\
\hline 3.3 A imagem no jornalismo & 43 \\
\hline 4 Informação pelo design & 47 \\
\hline 4.1 Princípios do design da informação & 48 \\
\hline 4.2 O design gráfico e o design da informação no jornalismo & 54 \\
\hline 5 Uma visão sobre infográficos & 57 \\
\hline 5.1 História e evolução & 57 \\
\hline 5.2 Conceituação & 60 \\
\hline 5.3 Classificações de infográficos & 74 \\
\hline 5.3.1 Reportagem infográfica: independente e específica & 76 \\
\hline 5.3.2 Estetizantes e analíticos & 76 \\
\hline 6 Modelo de caracterização de infográficos & 79 \\
\hline 6.1 Caracterização de peças infográficas & 79 \\
\hline 6.1.1 Eixo subordinado-independente & 80 \\
\hline 6.1.2 Eixo enciclopédico-específico & 81 \\
\hline 6.1.3 Eixo estetizante-analítico & 82 \\
\hline 6.2 Exemplo de aplicação de caracterização & 90 \\
\hline 7 Análise de infográficos & 97 \\
\hline 7.1 Definição do corpo de pesquisa & 97 \\
\hline 7.1.1 Materiais analisados & 98 \\
\hline 7.2 Procedimento & 99 \\
\hline 7.2.1 Guia de análise & 99 \\
\hline 7.2.2 Formulário de análise & 99 \\
\hline 7.2.3 Hipóteses & 101 \\
\hline 7.2.4 Representação visual do processo de análise de conteúc & \\
\hline
\end{tabular}




\begin{tabular}{|c|c|}
\hline 7.3 Resultados & 104 \\
\hline 7.3.1 Eixos subordinado-independente e enciclopédico-específico & 107 \\
\hline 7.3.2 Eixos estetixante-analítico & 110 \\
\hline 7.3 .3 Editorias & 114 \\
\hline 7.3.4 Variação temporal & 116 \\
\hline 8 Considerações finais & 117 \\
\hline 8.1 Resultados da análise de conteúdo & 117 \\
\hline 8.2 Aplicação do modelo em contexto de produção & 119 \\
\hline Referências bibliográficas & 121 \\
\hline Índice & 129 \\
\hline Apêndice & 133 \\
\hline
\end{tabular}




\section{INTRODUÇÃO}

A pesquisa apresentada é resultado de uma série de modificações que empurraram seu início para pontos anteriores à proposta original. A análise de infográficos gerou a necessidade de criação de um método; a criação do método exigiu a pesquisa histórica e definição de conceitos da área; finalmente, a conceituação da própria infografia não poderia ocorrer sem revisão teórica abordando as várias áreas do conhecimento que formam sua base.

Assim, o primeiro capítulo retorna a observações sobre as formas utilizadas pelo homem para se comunicar - especificamente a escrita (verbal) e a visual. Essas duas formas nasceram juntas, em evolução agora explicada pelos estudos da paleografia, e se modificaram com técnicas e tecnologias que afetaram de modos diferentes cada tipo de comunicação. Essas duas formas também nascem juntas no desenvolvimento de nossas habilidades cognitivas, $o$ que levou a pesquisa a uma incursão por essas ciências.

Duas áreas do conhecimento se destacaram pela proximidade com o estudo do infográfico: o jornalismo e o design da informação.

O segundo capítulo, sobre jornalismo, levanta informações sobre o contexto no qual infográficos são publicados. Reforçado pelos manuais de redação, o estilo do texto jornalístico se cristalizou no século 20 segundo princípios de clareza, precisão e objetividade. Esses mesmos princípios também se refletem na relação do jornalismo com o conteúdo imagético - da preferência pela fotografia por seu valor documental ao uso de gráficos quantitativos por sua qualidade de exatidão. Mas a influência do jornalismo não se restringe ao estilo. Por isso, é apresentada também uma reflexão sobre o que o diferencia das outras práticas de comunicação.

No terceiro capítulo, sobre design da informação, encontrou-se um campo científico novo e, por isso, é feita uma busca por definições e teorias, amparada em nomes-chave como Edward Tufte e William Cleveland.

Finalmente, o quarto capítulo é dedicado ao aprofundamento da conceituação do infográfico, utilizando a perspectiva história para enfatizar as relações e caminhos que deram forma à infografia. Assim, define-se o infográfico como uma construção narrativa que faz uso da não-linearidade para imprimir ritmo diferenciado de leitura e construir significados. Também são abordadas nesse capítulo algumas propostas de tipificação encontradas em trabalhos anteriores, como os de autoria de Cairo (2008) e de Teixeira (2007), mas que não apresentaram estudos sobre a construção de critérios de classificação.

A partir dessas propostas, é desenvolvido no quinto capítulo um modelo para orientar a caracterização e avaliação de infográficos. Esse modelo faz adaptações em teorias do design e estabelece eixo estetizante-analítico ${ }^{1}$ com quatro elementos que compõem um infográfico:

$1 \mathrm{Na}$ dicotomia de Cairo (2008), infográficos estetizantes priorizam a apresentação visual, enquanto os analíticos 
a integridade de seus dados, a usabilidade de seu formato, a aparência de sua apresentação e o conteúdo transmitido.

Outros dois eixos complementares foram identificados, relacionando o infográfico com a reportagem e com a proposta do veículo: enciclopédico-específico e subordinado-independente ${ }^{2}$.

O uso do modelo não se restringe a aplicações acadêmicas, propondo-se a orientar também a produção de infográficos nos veículos jornalísticos. Como teste de sua aplicação, o modelo foi utilizado em análise apresentada no sexto capítulo.

Entre os trabalhos específicos sobre infográficos, em geral norte-americanos e espanhóis, encontram-se bons levantamentos históricos sobre o uso da infografia na imprensa, questionamentos a partir da perspectiva da semiótica e até instruções para o trabalho do "infojornalista”. De modo geral, esses estudos apontam duas possibilidades para a seleção de exemplos: a) casos individuais para leitura e análise (de discurso) e b) polarização entre soluções elegantes e erros grosseiros.

Mas a análise apresentada no sexto capítulo tem outro tipo de proposta: em vez de exemplos, trabalhou-se com amostragens. Foram analisadas as características do conjunto de infográficos das edições selecionadas - os dois extremos e tudo o que está no intervalo entre eles -, com o objetivo de compreender as funções atribuídas pelos veículos de comunicação a esse elemento.

O trabalho envolveu a caracterização de peças infográficas encontradas em cinco jornais diários e duas revistas semanais, com três edições de cada veículo selecionadas com intervalos de seis meses. Por isso, além de funcionar como teste para o modelo, a análise também reuniu dados sobre o tipo de infográfico encontrado em veículos noticiosos brasileiros.

Assim, o estudo se propõe como ferramenta inicial para novas pesquisas sobre infográficos, aprofundando um campo de estudos ainda em desenvolvimento ligado a uma prática em período de transição. 


\section{COMUNICAÇÃO VERBAL E COMUNICAÇÃO VISUAL}

Você está jogando Imagem \& Ação e é a sua vez de desenhar. O peão da sua equipe chega a uma casa com a letra $\mathrm{O}$, e o cartão indica a palavra "meteoro". Com rabiscos desajeitados, seu lápis sugere uma forma com cauda, prestes a colidir com a Terra. Seus amigos têm uma boa chance de adivinhar a palavra.

No próximo lance dos dados, o seu peão para em uma casa marcada com a letra $\mathrm{A}$, e você encontra no cartão a palavra "devanear". Desta vez, as chances da sua equipe serão menores e seus esforços terão que compensar a dificuldade da nova palavra.

Se o seu primeiro desenho de um homem-palito sonhador falhar, você pode tentar uma composição mais complexa de desenhos que traduzam a mesma ideia. Dependendo do rigor dos demais jogadores, é provável que você comece a separar a palavra em sílabas. Se a sílaba "ne" não estiver funcionando e o tempo ainda não estiver esgotado, o desmembramento da palavra pode chegar às letras: um navio indicando o " $n$ ", em elefante indicando o "e"...

O jogo Imagem \& Ação funciona por causa de duas características. A primeira é a possibilidade da comunicação de ideias e palavras pelo uso de representações gráficas, o que viabiliza o jogo. A segunda é a dificuldade que se forma nas transposições palavra verbal (no cartão) $\rightarrow$ representação imagética (o desenho) $\rightarrow$ palavra verbal (a adivinhação feita pelo grupo), gerando o desafio.

A série de tentativas exemplificada anteriormente sintetiza o desenvolvimento da escrita que hoje utilizamos. Se a primeira palavra ("meteoro") podia ser traduzida em um desenho simples nas paredes das cavernas - ou na sua folha de papel -, a segunda palavra ("devanear") trouxe maior dificuldade.

Para Raskin (2008, p. 21, tradução nossa), as imagens falham na comunicação de ideias abstratas.

Como você representaria o marxismo pictoricamente? Você poderia tentar uma imagem de Marx, mas isso não faz a distinção entre pessoa e escola de pensamento (e exige que o observador conheça a aparência do Marx, ou seria apenas um cara com uma barba).

Imagens têm alta densidade informativa, mas palavras têm maior poder descritivo e de diferenciação. Apenas um desenho não parece dar conta das sutilezas que diferenciam o devaneio de um sonho. Talvez nem mesmo a combinação de desenhos provoque o resultado desejado. As tentativas seguintes são fonéticas - primeiro silábica e depois alfabética.

O funcionamento de cada estratégia é diferente. No exemplo do meteoro, o desenho de um corpo celeste com cauda não é específico e pode sugerir opções como "cometa". Assim, 
O jogo Pictionary foi criado nos EUA por Rob Angel em

1986

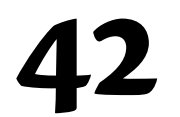

países já lançaram versões do jogo. No Brasil, são vendidas edições com os nomes Pictionary e Imagem \& Ação

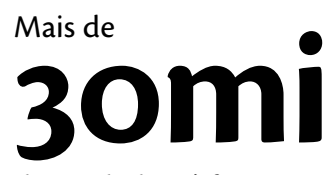

de unidades já foram vendidas no mundo todo

\section{Um jogo comunicativo}

Para vencer o jogo Imagem đ Ação, é preciso fazer com que os membros da equipe adivinhem qual palavra está sendo desenhada.

(1) Quatro ou mais jogadores são divididos em equipes.
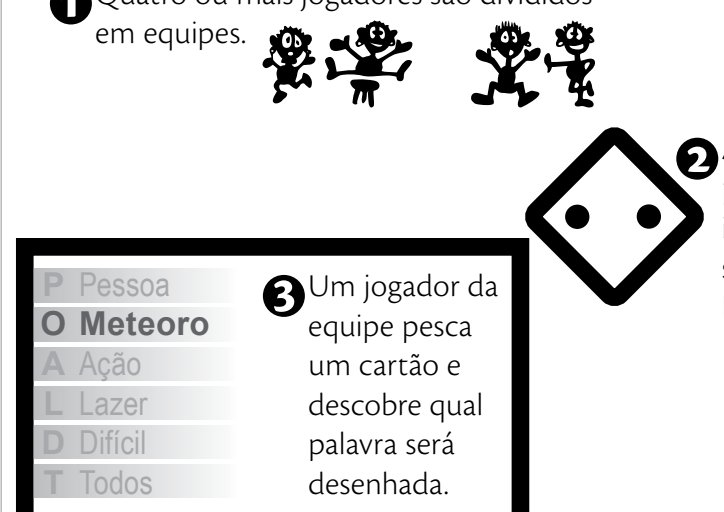

A primeira equipe joga o dado para mover o peão. Cada casa indica a categoria da palavra a ser jogada: Pessoa, Objeto, Ação, Lazer, Difícil e Todos jogam.

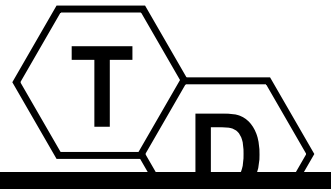

$4{ }^{\bigcirc}$ jogador tem 1 minuto para fazer desenhos que ajudem sua equipe a adivinhar a palavra. Não é permitido falar, fazer gestos ou traçar letras e números.

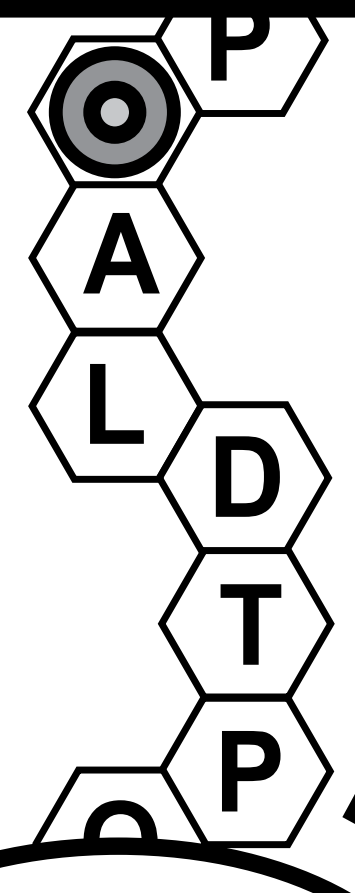

5 Se a equipe adivinhar a palavra a tempo, lança o dado novamente para jogar outra rodada. Vence a equipe que chegar primeiro à ultima casa do tabuleiro.

Fontes: Manual de instruções do jogo Imagem \& Ação; The playmakers: amazing origins of timeless toys, de Tim Walsh (2005) 
o jogador pode ver a necessidade de desenhar também a Terra, para apresentar um contexto de colisão que o diferencie de um cometa. Por sua vez, a decomposição da palavra em letras é um processo ordenado e demanda mais tempo para sua comunicação.

\subsection{ComunicaÇão E Sentidos}

Blake e Haroldsen (1977, p. 3, tradução nossa) iniciam Una Taxonomia de conceptos de la comunicación com uma tentativa de conceituar comunicação. Segundo os autores, uma das definições mais utilizadas é a de Berelson e Steiner (1964), de que comunicação é o ato ou processo de "transmissão de informação, ideias, emoções, habilidades, etc., mediante símbolos: palavras, imagens, dígitos, gráficos, etc.”.

Os autores notam, entretanto, que falta consenso sobre a abrangência do termo - alguns defendem que o processo comunicativo somente se concretiza quando o comportamento do receptor é afetado; também se discute a necessidade da intencionalidade do emissor para caracterizar um ato comunicativo.

Da mesma forma, Sfez (1994, p. 40) admite a abundância de definições "ao mesmo tempo próximas e divergentes", mas resume que "comunicar significa pôr ou ter alguma coisa em comum”. Entre essas e outras tantas definições, aceitamos nesta pesquisa que a comunicação seja um processo de compartilhamento de informações com o objetivo de transmitir sentidos ${ }^{3}$.

Reportando-se a Hartley e Hartley (1961), Blake e Haroldsen (1977, p. 4) também listam as três funções principais da comunicação: proporcionar um modelo de mundo, definir a posição do indivíduo em relação às outras pessoas e ajudar em sua adaptação ao ambiente. Essas três funções destacam a comunicação como a forma de nos relacionarmos com a realidade.

Torna-se evidente, então, o elo entre a comunicação e nossas capacidades sensoriais, pelas quais percebemos a realidade. Só é possível compartilhar informações se o indivíduo é percebido pelo outro, ou se percebe o outro. Nossa comunicação, portanto, depende dos nossos sentidos ${ }^{4}$.

Dondis (2007, p. 6) defende que a visão intensifica e supera os demais sentidos. "Buscamos um reforço visual de nosso conhecimento por muitas razões; a mais importante delas é o caráter direto da informação, a proximidade da experiência real”. Não à toa, expressões populares condicionam crer a ver.

Segundo Wurman (1990, p. 55), compreendemos informações e realizamos descrições utilizando três ferramentas: palavras, números e imagens. Similarmente, Müller-Brockmann

\footnotetext{
3 Esse processo de compartilhamento pode servir para a construção de nova informação por meio de trocas entre indivíduos e também para preservar informações do esquecimento (Flusser, 2008, p. 93).

4 É interessante notar que deficiências sensoriais levam à adoção de métodos comunicativos que fazem uso de outro dos sentidos. Se a deficiência é visual, a leitura pode ser feita pelo braile, uma escrita tátil. Se a deficiência é auditiva, a comunicação passa a depender de recursos visuais como a leitura labial e gestos.
} 
(2001, p. 9, tradução nossa) considera que "a palavra e a imagem são as pontes que unem os seres humanos", permitindo as relações entre o mundo físico e intelectual e o mundo social.

Essas concepções excluem de nossa paleta comunicativa outros recursos, como sons que não formam palavras 5 ou ações como um rolar de olhos. Assim, elas também evidenciam nossa tendência à visão como sentido comunicativo. Tanto ler textos verbais como apreender imagens são operações iniciadas na percepção visual. Na supremacia da visão, nossas ferramentas comunicativas seriam a escrita (palavras e números) e as imagens.

\subsubsection{Sistemas de escrita}

Durante ações de escrita e leitura, as 26 letras do alfabeto latino parecem tão naturais quanto nossos olhos e nossas mãos. Somente depois dessa observação ocorre uma estranha e breve reação, alguns momentos em que estas letras perdem sua aparência de naturalidade ${ }^{6}$.

"O alfabeto pode ser definido como um sistema de sinais que exprimem os sons elementares da linguagem” (Higounet, 2003, p. 59). Com a mesma função, sinais materiais como nós, entalhes e desenhos (Higounet, 2003, p. 9) já eram utilizados pelo homem primitivo - e continuam em uso nos dias atuais. Higounet detalha o desenvolvimento da escrita em três etapas essenciais: as escritas sintéticas, analíticas e fonéticas?.

O primeiro estágio da escrita, ocorrido por volta de 10 mil a.C., era "aquele em que um sinal ou um grupo de sinais serviu para sugerir uma frase inteira ou as ideias contidas numa frase" (Higounet, 2003, p. 13). Esse tipo elementar, a "escrita de ideias", seria a evolução natural das pinturas rupestres, que já sinalizavam rudimentos de escrita pela estilização.

Para Goody e Watt (2006, p. 24), esses sistemas de escrita exigem grande quantidade de símbolos e, mesmo assim, possibilitam a comunicação de um número limitado de mensagens:

Uma vez que símbolos são concretos, a sentença mais simples necessita de uma série muito elaborada de signos: muitas representações estilizadas de cabanas, pegadas, animais totêmicos e coisas como essas seriam necessárias apenas para levar a informação de que um homem partiu poucos dias atrás.

Um salto importante foi dado para o segundo estágio. A escrita analítica, ou "escrita de palavras”, surgiu com a decomposição da frase (Higounet, 2003, p. 13). Apesar da evolução

\footnotetext{
5 Ideias não são necessariamente palavras. Não são raras as situações em que temos uma ideia, mas encontramos dificuldades para expressá-la.

6 Para Flusser (2008, p. 90), nos esquecemos do caráter artificial da comunicação porque "os códigos (e os símbolos que os constituem) tornam-se uma espécie de segunda natureza” após terem sido aprendidos.

7 O próprio autor ressalva que essa classificação das escritas é "bem delicada, pois vimos que coexistem em quase todos os sistemas antigos elementos ideográficos e elementos fonéticos” (Higounet, 2003, p. 58). Entretanto, essa apresentação tem méritos didáticos e se ampara na predominância de cada tipo de elemento nos sistemas de escrita em cada época.
} 
em relação à primeira etapa, esse estágio também exige número elevado de sinais. Uma das consequências é a dificuldade em seu aprendizado. As regiões que desenvolveram esse tipo de escrita foram marcadas pela formação de uma "elite de religiosos letrados, administradores e comerciantes" e "governo burocrático centralizado" (Goody e Watt, 2006, p. 27).

Nessa categoria se enquadram escritas como os hieróglifos egípcios (c. 3300 a.C.) e a cuneiforme suméria (c. 3000 a.C.), que influenciaram nosso alfabeto. A escrita chinesa ${ }^{8}$, considerada analítica, continua em uso e confere unidade aos diversos dialetos do país (Higounet, 2003, p. 52).

A terceira etapa, a da escrita fonética, surgiu na passagem da notação de palavras para a notação de sons. Seja silábico ou alfabético, esse tipo permitiu a redução da quantidade de sinais gráficos.

O alfabeto protocaanita ${ }^{9}$ (c. 1450 a.C.), antecessor do alfabeto fenício, combinou elementos de quatro escritas (cuneiforme suméria, pictográfico hitita, escrita de Micenas e hieróglifos egípcios) em um conjunto que reunia entre 25 e 30 sinais. O alfabeto fenício reduziu esse número para 22 sinais consonantais que possibilitavam "escrever qualquer palavra" (Higounet, 2003, p. 65), e é considerado a origem ${ }^{10}$ de grande parte dos alfabetos surgidos posteriormente, como o $\operatorname{aramaico}^{11}$ (c. 800 a.C.), o grego ${ }^{12}$ e o latino, utilizado na língua portuguesa ${ }^{13}$.

Se, como propõe Fontana (2006, p. 175), a escrita fonética é o sistema gráfico para gravar a fala, não surpreende que os vinte e dois sinais organizados pelos fenícios formassem um alfabeto consonântico - como era sua língua. Também não surpreende que, ao se apropriarem dos sinais fenícios, os gregos tenham adaptado "o sistema de notação semítica às particularidades de sua língua” (Higounet, 2003, p. 90).

8 A escrita chinesa (surgida c. 1500 a.C.) influenciou outras escritas do leste asiático, como a japonesa (que incorporou seus sinais em um processo milenar até por volta do século $7^{\circ}$ ) e coreana (a Coreia desenvolveu alfabeto próprio por volta do século 15, mas várias de suas regras refletem a influência da escrita chinesa). A definição da escrita como ideográfica é contestada devido às relações entre a escrita e a fala chinesa.

9 Para Fontana (2006, p. 175), o desenvolvimento dos primeiros alfabetos ocorreu na baixa Mesopotâmia devido à prosperidade econômica e comercial da região, gerando a necessidade de uma forma universal de escrita para controlar as trocas entre povos de línguas distintas.

10 A quantidade reduzida de caracteres é um dos motivos para a disseminação do alfabeto fenício, mas esse processo também se relaciona com condições históricas como as rotas e trocas comerciais entre as civilizações da época.

$11 \mathrm{O}$ alfabeto aramaico foi utilizado durante curto período de tempo, mas teria dado origem às escritas hebraica (300

a.C.) e árabe (400 a.C.).

12 A escrita grega também deu origem à escrita cirílica (século $10^{\circ}$ ).

13 Entre todos os alfabetos itálicos, o alfabeto que chamamos de "latino" se impôs porque era "o alfabeto do povo vencedor" (Higounet, 2003, p. 105). Junto com o império, o alfabeto se espalhou pela península itálica e mais tarde pelo Ocidente antigo. 


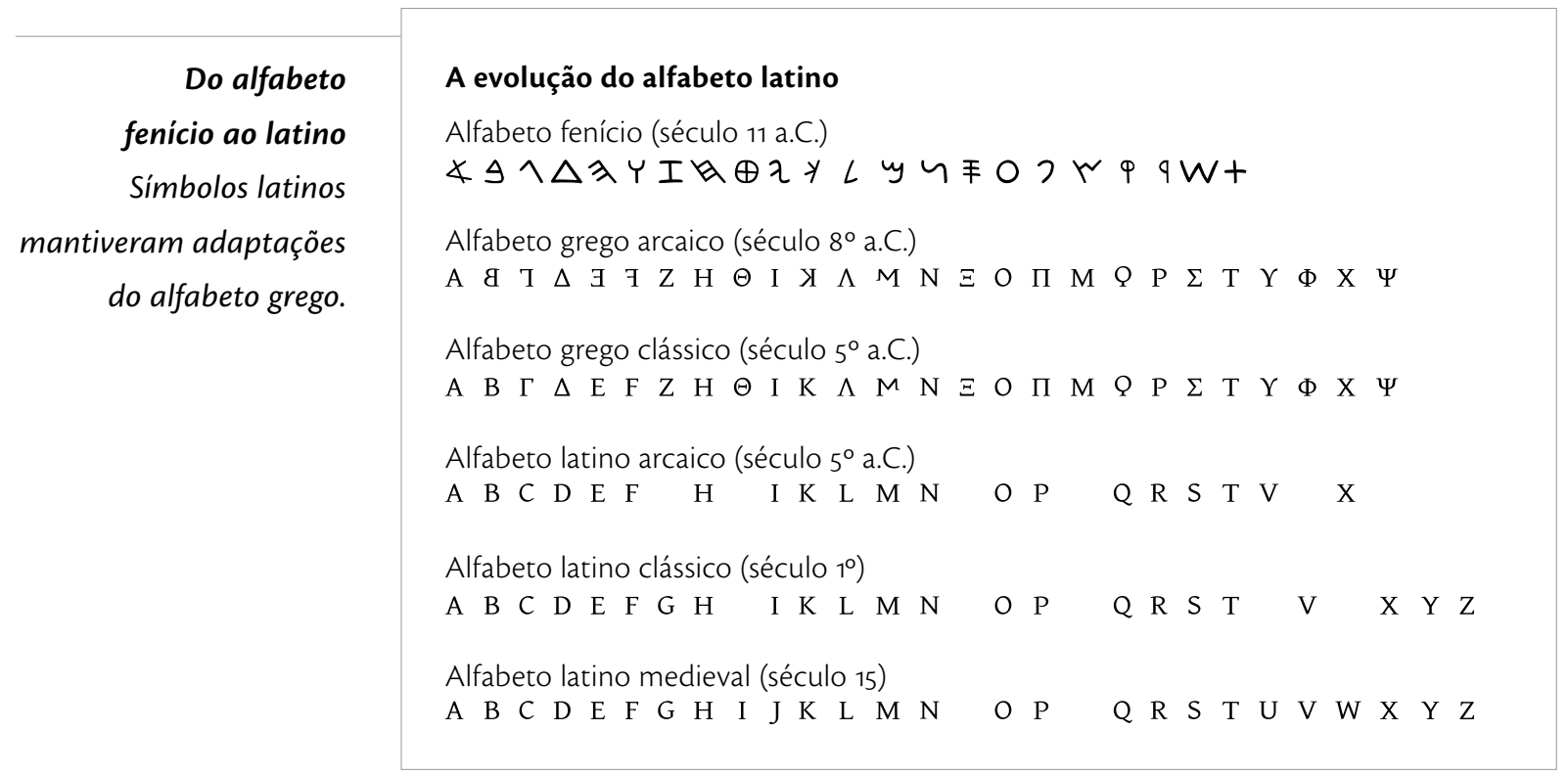

A principal adaptação do alfabeto grego (c. 800 a.C.) foi a transformação dos sinais fenícios cujos sons não eram utilizados em sua língua - essencialmente, os que representavam sons guturais - em vogais.

O alfabeto latino, que incorporou influências das escritas italianas ao alfabeto grego, encerrou seu processo de gênese por volta do século $1^{\circ}$ a.C.; nos séculos seguintes, os sinais ainda passaram por evoluções gráficas até que uma forma se tornou predominante.

Além dos sinais, a escrita latina também adotou outra característica dos gregos: a scriptura continua. Segundo Saenger (1995, p. 220), a ausência de espaço entre palavras foi possibilitada pelo "advento da reprodução dos sons da fala sem ambiguidade", trazido pelas vogai ${ }^{14}$. A cultura grega possuía forte tradição oral (Svenbro, 1998, p. 41), de modo que a leitura em voz alta dos textos em scriptura continua permitia a identificação sonora das palavras. Sem enfrentar preocupações com a velocidade e facilidade da leitura, a scriptura continua prevaleceu na escrita latina até a Idade Média ${ }^{15}$.

Apesar da redução do número de sinais, a democratização da escrita dependeria de fatores sociais e econômicos. Somente entre os séculos 12 e 13 a escrita se difundiu na Europa,

14 As escritas semíticas, consonantais, continham separações entre palavras para permitir sua decifração. Curiosamente, uma das alterações da escrita abreviada da comunicação online e via sMs (mensagens de texto de celular) é a abreviação ortográfica. Perea, Acha e Carreiras (2009, p. 3, tradução nossa) notam que a abreviação costuma ocorrer com a remoção de vogais, indicando que os usuários dessa linguagem parecem "implicitamente conscientes do valor informativo muito superior das consoantes em relação às vogais”.

Fusca (2008, p. 11) também argumenta que “é mais fácil para o leitor inferir as vogais que constituem a sílaba do que as consoantes - uma vez que o número de vogais é menor do que o de consoantes”.

15 Os manuscritos de monastérios irlandeses adotaram a separação de palavras por volta do século 12. As diferenças com a língua local (Saenger, 2000, p. 41) dificultavam a leitura dos textos sagrados em latim. 
acompanhando o surgimento de universidades, o desenvolvimento econômico e bancário e o renascimento do direito romano (Higounet, 2003, p. 139). Essas condições levaram ao aumento da demanda por livros, ainda manuscritos - e, assim, raros e caros.

A prensa de tipos móveis de Gutenberg ${ }^{16}$, no século 15, trouxe o nascimento da "grafia mecânica que permite a reprodução quase ilimitada de letras sempre idênticas a si mesmas" (Higounet, 2003, p. 159). Na época, os tipógrafos inspiraram seus modelos nos principais tipos de escrita latina, derivados da escrita carolíngia, uniformizando, finalmente, o desenho dos sinais.

\subsubsection{A reprodução da imagem}

Conforme os estudos da área da paleografia, a representação imagética antecedeu a escrita. Entretanto, o verbal se sobrepôs ${ }^{17}$ ao imagético como sistema de comunicação gravada em suportes.

Logos, a palavra grega que designa linguagem, inclui também os significados paralelos de "pensamento" e "razão" na palavra inglesa que dela deriva, logic. As implicações são bastante óbvias: a linguagem verbal é vista como um meio de chegar a uma forma de pensamento superior ao modo visual e ao tátil. (Dondis, 2007, p. 15)

Socialmente, a escrita se restringia ${ }^{18}$ a grupos administrativos e clericais. A consciência histórica dos textos passou a programar a sociedade, mantendo a ordem social vigente. Mas, assim como a escrita não eliminou a fala, tampouco a imagem desapareceu: "a massa continuou a ser programada por imagens, apesar de serem imagens infectadas por textos” (Flusser, 2008, p. 134).

Inúmeros movimentos e estilos se sucederam nas artes visuais ao longo dos séculos, mas sem o mesmo valor de documentação e difusão de conhecimento que a escrita. Havia casos, entretanto, do uso da imagem como ferramenta comunicativa ou didática de conhecimentos religiosos $^{19}$. Os painéis e vitrais das igrejas contavam passagens bíblicas, enquanto a Bibliae

16 A prensa de tipos móveis de Gutenberg foi antecedida por invenções que seguiam o mesmo princípio, mas em terras orientais. Na China, tipos móveis eram feitos de madeira e argila; entretanto, essa técnica não trazia as mesmas vantagens para um sistema de escrita com tantos sinais como o chinês.

17 "A filosofia grega e a profecia judaica são exemplos de luta dos textos contra as imagens: Platão, por exemplo, desprezou a pintura, e os profetas bradaram contra a idolatria” (Flusser, 2008, p. 133-134).

18 Ainda que se considerem os alfabetos derivados do fenício (principalmente o latino) como universais, a escrita demorou a se disseminar além da elite da época. Passaram-se séculos entre a introdução da escrita a sua difusão.

19 Historicamente, várias religiões abraâmicas posicionaram-se contra a imagem. Deus é ouvido, e não visto; é a "Palavra”. O judaísmo pregou contra a adoração de ícones, enquanto a representação visual de Deus ou de Maomé gera polêmica no islamismo. O Bilderverbot também estava presente no cristianismo em seus primeiros séculos, permane- 
pauperum ${ }^{20}$ transformava os ensinamentos do livro sagrado em cenas, como livros ilustrados (Manguel, 2002, p. 123).

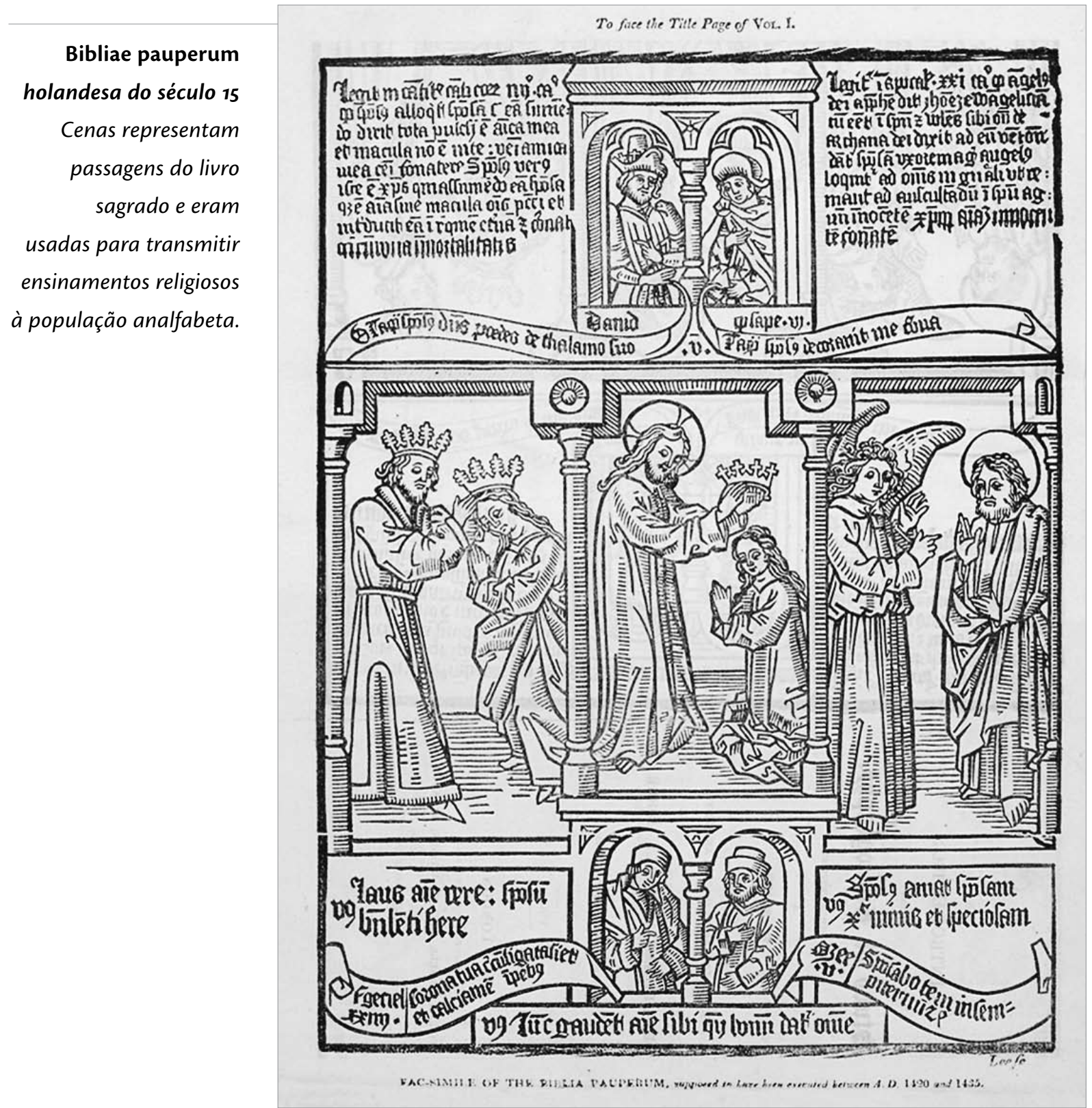

Para Huerta (2003, p. 73), o domínio da palavra sobre a imagem até o Renascimento se deveu ao fato de que as convenções das linguagens escritas e faladas se desenvolveram mais

cendo em certas vertentes protestantes.

20 Apesar do nome, a Bibliae pauperum era um livro caro, que não poderia ser comprado pelos pobres. É provável que tenha sido utilizada por religiosos como instrumento didático, para transmitir os ensinamentos sagrados à população analfabeta. 
rapidamente. As propriedades da palavra que garantiram essa prevalência eram a repetibilidade, portabilidade e maleabilidade - verdadeiros obstáculos para a imagem.

Livros eram copiados manualmente, mas o copista precisava saber identificar e reproduzir apenas um conjunto limitado e reduzido de símbolos (o alfabeto). E, ainda que as letras não fossem idênticas, o sentido era preservado. O mesmo não ocorria com as ilustrações:

Desenhos técnicos feitos à mão (...) logo degeneraram em manuscritos, porque até mesmo os artistas habilidosos não entendiam a ilustração que estavam copiando, a menos que fossem supervisionados por um perito no campo a que as ilustrações se referiam. (Ong, 1998, p. 145)

Já se conheciam técnicas para o entalhe de imagens em blocos para impressão, como a xilogravura, antes da prensa de tipos móveis, mas seu uso não era frequente porque não se inseria à lógica da produção manuscrita. Somente com a imprensa ${ }^{21}$ é que esses blocos de impressão tiveram seu uso ampliado - "substituindo uma caixa de tipografia pela prancha de madeira com a imagem gravada” (Peltzer, 1992, p. 105) -, o que possibilitou a reprodução de ilustrações.

Ainda assim, a integração real das técnicas de impressão de textos e imagens ocorreu somente séculos mais tarde. Segundo Arbach (2007, p. 111), não havia "compatibilidade mecânica para unir no mesmo processo de impressão a matriz tipográfica com a matriz xilográfica, impedindo a multiplicação das imagens em conjunto com a multiplicação dos textos”.

\subsubsection{Palavras e imagens}

Escrita e imagem são classificadas como ferramentas comunicativas (Wurman, 1990, p. 95 e Müller-Brockmann, 2001, p. 9), e seu papel é reforçado devido à nossa preferência pelo sentido da visão (Dondis, 2007, p. 6). Mas elas possuem características distintas, fazendo com que cada uma seja mais ou menos apropriada para cada comunicação.

A favor da escrita, Goody e Watt (2006, p. 31) argumentam que "o alfabeto torna possível ler e escrever facilmente e sem qualquer ambiguidade todas as coisas sobre as quais a sociedade possa falar”. Macy, Anderson e Krygier (2000, p. 296, tradução nossa) também defendem que

... cada aumento na complexidade de nossos veículos de comunicação - as mudanças de linguagens pictográficas a alfabetos abstratos ou de pintura em cavernas para manipulação digital de imagens - tem sido motivado por um desejo de melhorar o alcance e riqueza dos significados que podemos compartilhar.

No entanto, a escrita é um recurso essencialmente simbólico. Não há similaridades entre a grafia de uma palavra e o objeto que ela representa; como consequência, não é possível adi-

21 Era comum que os elementos decorativos dos primeiros livros impressos fossem realizados manualmente. 
vinhar os significados. A comunicação escrita não é possível quando um dos interlocutores desconhece o código.

Já a imagem é uma representação gráfica das coisas reais e imaginárias (Costa, 1998, p. 219). Ela simula os contornos do objeto, permitindo que o observador faça a identificação mesmo sem compartilhar do exato código ${ }^{22}$ do emissor. Por isso, a imagem frequentemente é considerada adequada para a comunicação com públicos não-alfabetizados.

A ideia de "universalidade" se reforça porque, em oposição à linguagem escrita, a imagem não é afetada pela pluralidade de idiomas espalhados ao redor do mundo. Mas buscar sentido em uma imagem é um processo interpretativo e, portanto, tem seus limites culturais e também individuais. A imagem está mais sujeita à ambiguidade indesejada do que a linguagem verbal ${ }^{23}$. Assim, significados podem ser atribuídos a uma imagem, mas eles nem sempre correspondem à mensagem prevista. "A visão é natural; criar e compreender mensagens visuais é natural até certo ponto” (Dondis, 2007, p. 16).

Como as imagens tentam reproduzir (e até substituir) o objeto concreto, Flusser (2008, p.115) defende que o pensamento imagético representa o fato "de forma mais completa". A palavra, por sua vez, busca reduzir a ambiguidade da mensagem, fazendo com que o pensamento conceitual represente o fato "de maneira mais clara".

Os modos como entramos em contato com cada tipo de mensagem também são distintos. "Precisamos seguir o texto se quisermos captar sua mensagem, enquanto na pintura podemos apreender a mensagem primeiro e depois tentar decompô-la” (Flusser, 2008, p. 105).

\subsection{Aspectos Fisiológicos e cognitivos}

Aceitando-se que a linguagem verbal e a linguagem imagética têm efeitos comunicativos distintos, espera-se que nos relacionemos de formas diferentes com imagens e com textos escritos. Para buscar essas diferenças, parte-se do processo comum: a percepção visual.

A cada instante, nossos olhos recebem milhões de estímulos visuais. Algumas das tentativas de se compreender como enxergamos e percebemos o mundo visual foram feitas em pesquisas das ciências cognitivas ${ }^{24}$. Uma estratégia frequente é a medição dos movimentos feitos pelos olhos durante uma atividade de percepção visual.

22 Para Flusser (2008, p. 114), o alfabeto é um código conceitual objetivo, que tem sempre o mesmo significado (a letra “a” sempre será a letra “a”), mas que precisa ser aprendido conscientemente. Já o código imagético é subjetivo. Ele depende de pontos de vista predeterminados e suas convenções são inconscientes.

23 Assim funciona a legenda de uma foto no jornalismo: o texto explica a imagem, reduzindo a incerteza.

24 Vignaux (1991, p. 7) considera que a finalidade das ciências cognitivas é descrever, explicar e simular capacidades humanas como a linguagem, o raciocínio, a percepção e a coordenação motora. Herman (2003, p. 4) defende que as ciências cognitivas compreendem seis disciplinas: filosofia, psicologia, neurociências, inteligências computacional, linguística e linguagem, e cultura, cognição e evolução. 
EM BUSCA DO ESPERANTO VISUAL

A edição mais recente do catálogo Ethnologue (2009) conta 7358 línguas ainda faladas. A estimativa do catálogo é que as 10 línguas mais faladas no mundo todo (mandarim, espanhol, inglês, árabe, hindi, bengali, português, russo, japonês e alemão) sejam as línguas nativas de pouco menos de metade da população mundial.

A multiplicidade de idiomas e as dificuldades de comunicação decorrentes dela inspiraram uma série de propostas para a criação de uma língua auxiliar internacional. Entre elas, a mais conhecida é o Esperanto, proposto por Ludwik Lejzer Zamenhof em 1887. Embora a língua ainda seja usada, sua influência é bem mais modesta do que o sonho de seu criador.

Outra conhecida proposta de linguagem internacional auxiliar é o Blissymbol. Seu criador, o austríaco Charles K. Bliss, inspirou-se nos caracteres chineses enquanto era refugiado na China, durante a Segunda Guerra Mundial. Lançado em 1949, o Blissymbol se diferencia de propostas como o Esperanto por ser uma linguagem ideográfica e que não é falada.

Para contornar os inconvenientes das escritas ideográficas - como a grande quantidade de símbolos, dificultando sua aprendizagem e reprodução -, o Blissymbol reutiliza várias estruturas e opta por traços simples, frequentemente representados em grids. A técnica pode ser compreendida visualmente.

O uso atual do Blissymbol também é diferente de sua proposta inicial. Desde a década de 1960, ele passou a ser adotado

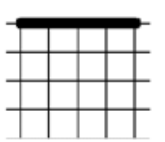

céu

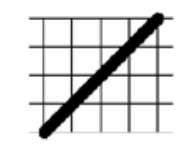

caneta, escrita
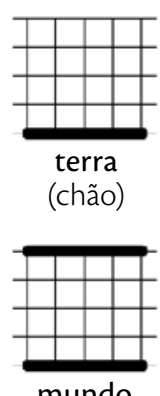

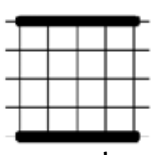

mundo

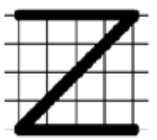

Blissym (escrita do mundo) para a comunicação de pessoas com deficiências como a paralisia cerebral.

Ao lado do Blyss, outro conhecido sistema de sinais gráficos é o IsOTYPE idealizado por Otto Neurath e desenhado por Gerd Arntz. Defendendo que "Palavras dividem; imagens conectam" (Neurath, 1936, p. 18), Neurath não ambicionava construir uma nova linguagem, mas uma ferramenta auxiliar para educação e comunicação.

\section{Blissymbolics}

Combinações criam novos símbolos.
Os pictogramas deveriam ser simples e claros. Mesmo afirmando a internacionalidade da representação gráfica, o IsOTY PE possuía regras e instruções para a combinação de sinais. Previa-se, entretanto, que sua interpretação não exigia aprendizado.

Uma das aplicações previstas por Neurath para o IsOTYPE eram instruções,

\section{ISOTYPE}

Regras orientam a

combinação de sinais. (trabalhador da 


\author{
principalmente se houvesse barreira \\ linguística - como um viajante, por \\ exemplo. Existem hoje conjuntos de \\ pictogramas criados especialmente para \\ esse tipo de comunicação, como o do \\ Departamento de Transportes norte- \\ americano. \\ Também se sugeria o uso do \\ ISOTYPE em representação estatística \\ - os pictogramas complementariam \\ informações quantitativas, consideradas
}

igualmente internacionais. $\mathrm{O}$

uso pioneiro de pictogramas em

representações estatísticas é creditado

a Michael George Muhall, ao final do

século 19, mas Neurath "desenvolveu uma metodologia para mostrá-las de forma eficaz" (Horn, 2000, p. 18).

Esse tipo de recurso ainda é visto em infográficos atuais, ainda que os pictogramas utilizados não sejam os criados por Arntz.

Nossa operação visual não é contínua. Quando observamos uma cena ou lemos um livro, alternamos fixações e movimentos (chamados sacádicos). Acredita-se que imagens possibilitam o reconhecimento de informações centrais mesmo de relance - mas em observações mais alongadas ocorre o processo de fixações e movimentos que permite a apreensão de detalhes (Liversedge e Findlay, 2000, p. 8). Embora ainda não se saiba explicar os movimentos e destinos escolhidos por cada pessoa ao observar um objeto pictórico, Brandt e Stark (1997, p. 28) defendem que essa exploração visual não é aleatória, mas sim relacionada ao conteúdo da cena.

O movimento ocular realizado durante a leitura de um texto tampouco é aleatório. Uma frase é lida em uma sequência de fixações e movimentos progressivos e regressivos, até que o leitor capture todas as informações. Segundo Calabaça (2007, p. 21), "as fixações nunca ocorrem entre palavras, e, na sua maioria, verificam-se à esquerda do meio de uma palavra”.

A cada fixação, uma quantidade limitada de caracteres é assimilada - o que não ocorre durante o "salto" do olhar para o ponto de fixação seguinte. Na descrição de Barthes e Compagnon (1977, p. 189), “a leitura tem portanto um ritmo em dois tempos: deslocação/paragem do olhar, ou não-leitura/leitura”.

\section{Movimentos sacádicos \\ Observação de imagem e leitura de texto \\ são realizadas com sequências de fixações $e$ movimentos.}
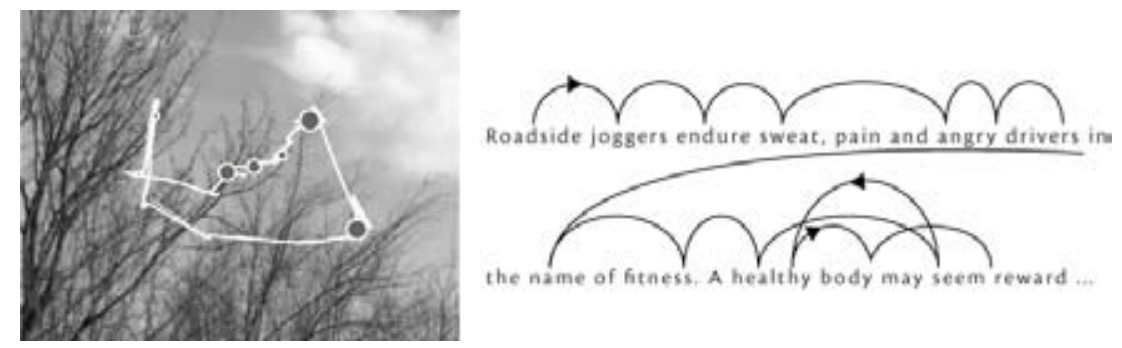

O movimento ocular ocorre porque, entre aqueles milhões de estímulos visuais que chegam aos nossos olhos, são percebidos com maior acuidade somente aqueles que atingem a 
fóvea ${ }^{25}$. Esse movimento seria responsável pela organização das partes para construir a imagem visualizada (Brandt e Stark, 1997, p. 27).

Mas o processo de percepção visual ainda percorre mais passos. Segundo Ramachandran (2002, p. 108),

o sistema visual parece ter uma organização total relativamente simples. Mensagens dos globos oculares passam pelo nervo óptico e imediatamente se bifurcam ao longo de duas vias - uma filogeneticamente antiga, e uma segunda, mais nova, que é mais desenvolvida nos primatas, inclusive humanos.

A primeira via está ligada a questões de sobrevivência. É na segunda via que ocorrem os processos da percepção consciente, aquilo que chamamos de "enxergar". Essa segunda via chega ao córtex visual primário, com cerca de trinta áreas para processar imagens. Temos na verdade vários sistemas visuais, acionando diferentes subconjuntos de áreas especializadas para cada tipo de tarefa e de atributo visual.

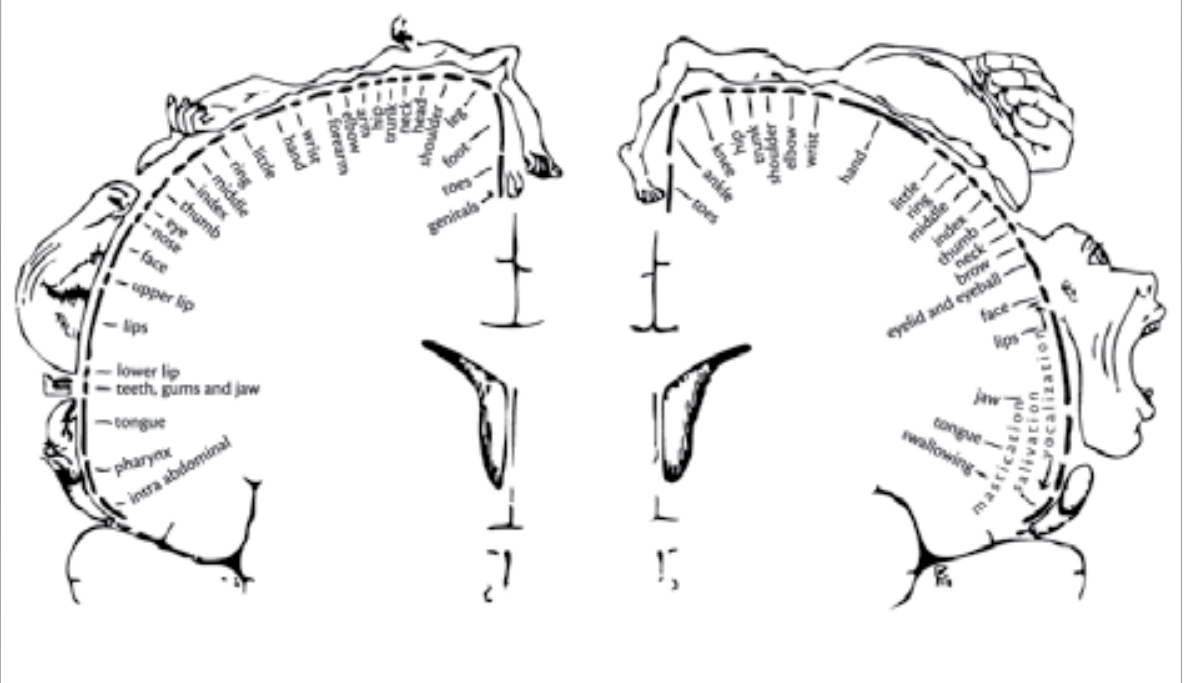

Homúnculo de Penfield

Mapa relacionando

porções do cérebro

e as partes do corpo

correspondentes,

de acordo com as

descobertas de Wilder

Penfield.

Embora não exista um mapa definitivo de todas as funções e processamentos realizados em cada área de nosso cérebro, um pouco do funcionamento é conhecido. Ramachandran (2002, p. 108) afirma que as informações visuais transmitidas na segunda via se desviam em duas direções. No lobo parietal, é processada a informação espacial - além do "onde”, essa informação também organiza ações como andar e alcançar o objetos (o "como"). Já o lobo temporal realiza a identificação dos objetos (o "o quê").

Parece, portanto, bastante provável que o processamento da informação visual textual também seja realizado em uma área específica. Citando o trabalho de Stanislas Dehaene,

25 A fóvea é uma porção da retina na qual há grande concentração de células sensoriais. É nessa região da retina que a visão possui mais definição e nitidez. 
Wolf, Maryanne (2008, p. 12) argumenta que a capacidade de ler - ou reconhecer letras e palavras - foi desenvolvida a partir de uma habilidade anterior: a de reconhecer objetos.

Quando humanos olham para linhas que não representam significados, ativamos apenas áreas visuais limitadas localizadas nos lobos occipitais e na parte de trás do cérebro. (...) Quando vemos os mesmos círculos e linhas e os interpretamos como símbolos significativos, no entanto, precisamos de novos caminhos [no cérebro]. (Wolf, Maryanne, 2008, p. 29, tradução nossa).

\section{As vias do sistema de percepção visual \\ De acordo com \\ Urgerleider e Mischkin \\ (1982; citados por \\ Ramachandran), $a$ via "como" se destina \\ a funções espaciais, enquanto a via "o quê"} faz o reconhecimento de objetos.

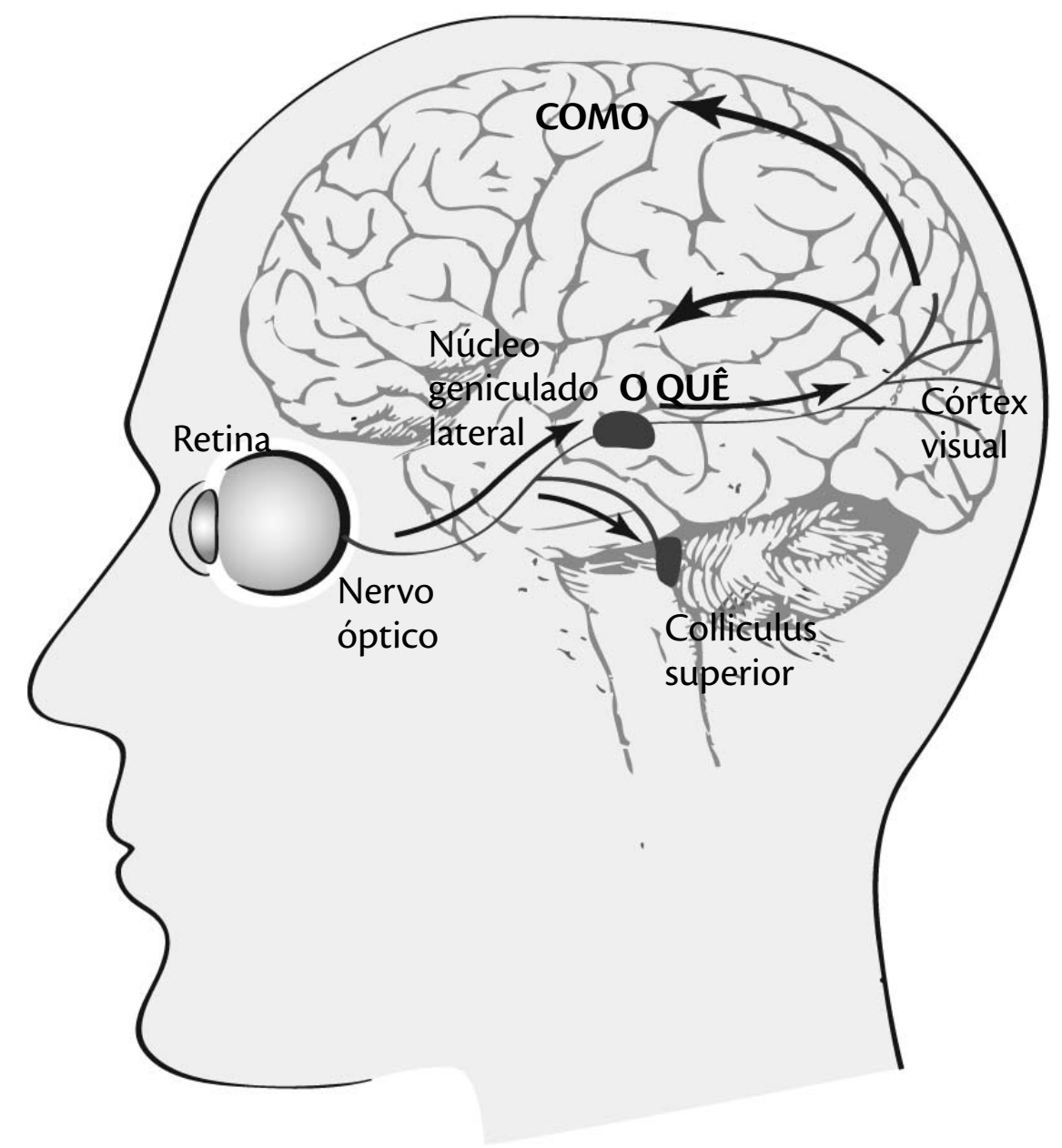

O tipo de leitura se relaciona com o tipo de transcrição - se a escrita é fonética, como nosso alfabeto, há uma articulação fonética (seja ela física, com a leitura em voz alta ou balbuciada, ou uma voz mental); se a escrita é ideográfica, como a chinesa, há acesso mais direto à ideia. A partir de estudos feitos com leitores japoneses ${ }^{26}$, por exemplo, sugere-se que "os processos cerebrais para decodificarem os ideogramas, em oposição aos que decodificam transcrições fonéticas, ocorrem em pontos distintos do cérebro" (Saenger, 1995, p. 213). 
Para Gerrig e Egidi (2003, p. 34), o salto entre o símbolo gráfico e a narrativa é um processo cognitivo - a decodificação de letras e palavras (a partir da percepção visual), atribuindose um significado a elas. Assim, parece que a atribuição de significado é a chave para os dois tipos de comunicação. Ler palavras e observar imagens são dois caminhos diferentes na mesma busca de uma narrativa para fazer sentido do mundo.

\subsection{NarRativas}

Para Bruner (1991, p. 4), narrativa é a forma que utilizamos para organizar nossa experiência e nossa memória - e construir uma realidade. A narrativa torna-se um recurso para compreender o mundo (Herman, 2003, p. 185).

Wurman (1990, p. 236, tradução nossa) defende que as histórias exercem papel fundamental na transmissão e memorização de fatos e dados. Histórias "incentivam a aplicação da informação e é isso que lhe dá sentido". Um exemplo é a estratégia bíblica de transmissão de regras de conduta através de parábolas - histórias que podem ser facilmente compreendidas e memorizadas pelos integrantes da religião.

Nessa mesma lógica, Abbott propõe que a compreensão da teoria da seleção natural de Darwin tem como obstáculo a dificuldade para sua narrativização (2003, p. 143). Existem mudanças ocorridas ao longo de um intervalo de tempo, mas não se percebe ação ou intencionalidade ${ }^{27}$ dos envolvidos nessas mudanças de estado. Da mesma forma, não há uma força ou entidade consciente (ou onisciente) agindo por trás dos eventos.

Para Abbott (2003, p. 147), a narrativa da teoria da seleção natural se divide em dois níveis de compreensão: o primeiro é o da mudança evolutiva (Espécie $\rightarrow$ Espécie $\rightarrow$ Espécie $\rightarrow$ Espécie); o segundo é o dos eventos cotidianos (indivíduos morrendo, indivíduos sobrevivendo, indivíduos se reproduzindo). Entretanto, os indivíduos do segundo nível são indiferentes à existência do primeiro nível. Já a teoria criacionista opera em uma narrativa clássica de eventos interligados em relações de causa e consequência: "Criação $\rightarrow$ Desobediência $\rightarrow$ Queda $\rightarrow$ Nova desobediência $\rightarrow$ Dilúvio...” (Abbot, 2003, p. 152, tradução nossa)

A função da narrativa é, de certa forma, bastante similar à exercida por nossos olhos e nosso cérebro: organizar fragmentos de informação para criar significado. Em composições textuais, a narrativa se forma na ordenação sintática das palavras. Para Flusser (2008, p. 132), a narrativa é uma invenção da linha, que desenrola e ordena a cena.

Mas Manguel (2001, p. 25) também vê a narrativa nas imagens ${ }^{28}$, ainda que elas existam em dimensões diferentes (a narrativa no tempo; a imagem no espaço). Os painéis medievais frequentemente representavam sequências narrativas "com o mesmo personagem apare-

27 Em fábulas e histórias infantis nas quais os protagonistas são animais ou objetos, essas personagens recebem características comportamentais humanas.

28 Bruner (1991, p. 6) reconhece que mídias não-verbais como histórias em quadrinhos possuem convenções de diacronia: "da esquerda para a direita” ou "de cima para baixo", por exemplo. 
cendo várias vezes em uma paisagem unificadora, à medida que ele avança pelo enredo da pintura". Essa linguagem se modificou essencialmente no Renascimento, com a perspectiva e o congelamento de instantes únicos em quadros. "A narrativa, então, passou a ser transmitida por outros meios: mediante 'simbolismo, poses dramáticas, alusões à literatura, títulos' - ou seja, por meio daquilo que o espectador, por outras fontes, sabia estar acontecendo".

\section{A Árvore da Vida}

A Árvore da Vida de Darwin mostra as relações entre as diversas espécies de seres vivos, mas não representa informações temporais e tampouco explica o processo de seleção natural.

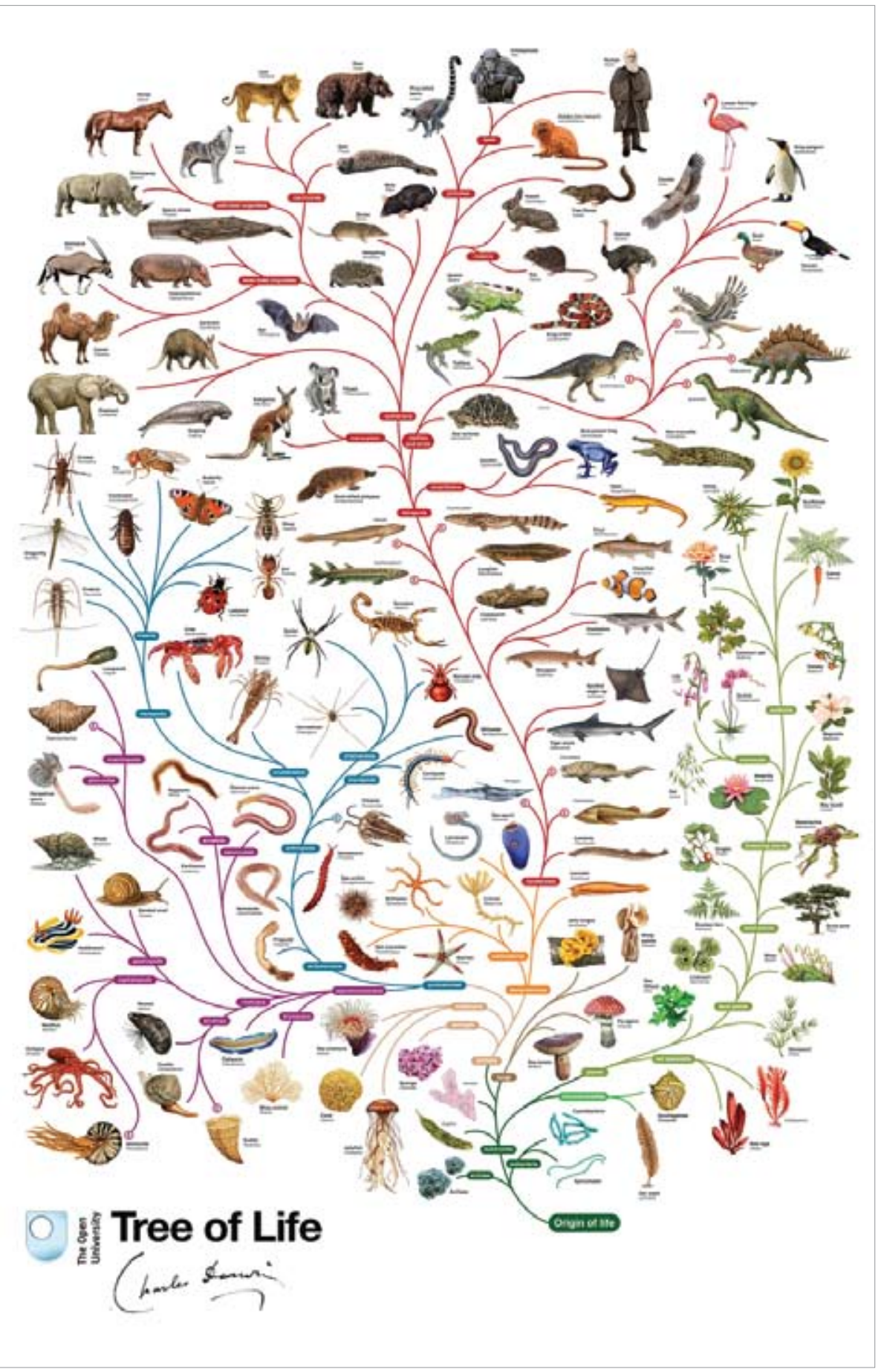




\section{ESTILO NO JORNALISMO}

"Complexo de Clark Kent" é uma expressão conhecida nas faculdades de jornalismo. O habitual idealismo dos aspirantes à profissão inspira a referência ao repórter do Planeta Diário que, entre uma pauta e outra, salva o mundo. Entretanto, o jornalismo parece menos bemintencionado no estudo das comunicações.

Em definições simplistas, a área se polarizou entre a pesquisa funcionalista e a teoria crítica. A primeira, norte-americana, tinha vocação administrativa e se especializava no estudo dos efeitos com enfoques "relacionados com a exploração econômica (publicidade), a militar e a política (propaganda) e os resultados da investigação" (Kunczik, 1997, p. 19). Do outro lado do Atlântico, a segunda denunciava a "manipulação do público - buscada e conseguida pela indústria cultural" (Wolf, Mauro, 2008, p. 82). Entre uma e outra, o jornalista e seu complexo de Clark Kent estariam destinados a controlar, e não a libertar.

Entretanto, de acordo com levantamento feito por Kunczik (1997, p. 16), "em geral, o jornalismo tem uma definição mais estreita que a de comunicador" - muitas vezes separando-o do entretenimento. Kovach e Rosenstiel (2003, p. 20) reforçam que o jornalismo deve fornecer "informação independente, confiável, precisa e compreensível, elementos importantes para que o cidadão seja livre”.

De acordo com esse quadro, a pesquisa considera que a finalidade do jornalismo é defender os direitos do cidadão por meio da transmissão de informações importantes. Estudar como essa transmissão ocorre deve, portanto, orientar-se pela busca por estratégias mais adequadas para que o jornalismo cumpra sua finalidade.

\subsection{O PAPEL DO JORNALISMO HOJE}

"Imagine um mundo [...] no qual o governo, as empresas, os lobistas, os candidatos, as igrejas e os movimentos sociais fornecem informação diretamente aos cidadãos em seus computadores domésticos" (Schudson, 1996, p. 1, tradução nossa). Esse mundo imaginário foi proposto em meados da década de 1990, quando a internet comercial começava a se popularizar, e ganhou ainda mais pertinência nos anos da chamada web 2.0, que prega a participação do usuário como produtor de conteúdo. No mundo imaginado pelo autor, o jornalismo seria inicialmente abolido, e todos - "a Audubon Society e a Ku Klux Klan, criminosos na prisão, crianças no acampamento de verão, idosos em asilos, o sem-teto urbano e o recluso rural" - passam a receber e a enviar mensagens.

Até que o cidadão buscaria ajuda para lidar com tanta informação. Em que confiar? O que é mais relevante? Como entender e interpretar tudo aquilo? "Jornalismo - de algum tipo seria reinventado”, acredita o Schudson (1996, p. 1, tradução nossa). 
Esse exercício de imaginação revela três importantes funções do jornalista em momento no qual todos produzem e enviam informações: verificar, selecionar e explicar.

\section{a) Verificação}

A notícia não é o fato, mas o relato desse fato $^{29}$. Não é exagero afirmar que cada acontecimento dá origem a múltiplos relatos - de cada testemunha, de cada envolvido, de cada indivíduo que ouve falar sobre o acontecimento e reconta uma nova versão. Essa tendência foi amplificada pelas ferramentas tecnológicas atuais, que transformam cada indivíduo em um produtor e emissor de informação.

Se há múltiplas versões, há também conflitos entre elas. Sem qualquer tipo de interferência, a incerteza tem como consequências o reforço da versão "oficial” (e, assim, o reforço ao poder estabelecido, menos questionado) e a difusão de rumores.

No fim, a disciplina da verificação é o que separa o jornalismo do entretenimento, da propaganda, da literatura ou da arte. [...] Só o jornalismo se concentra primeiro em registrar direito o que aconteceu. (Kovach e Rosenstiel, 2003, p. 113)

b) Seleção

O desenvolvimento de tecnologias de processamento e transmissão de dados - e o consequente crescimento dessa indústria - aumentou drasticamente a quantidade de informações às quais os cidadãos são expostos diariamente.

\footnotetext{
A quantidade de notícias que se espera que ingiramos diariamente dificulta nossa capacidade de perceber [...]. Não apenas torna-se mais provável que cometamos erros de percepção, mas quanto mais tempo passamos com relatos de eventos separados, menos tempo temos para entender os "porquês e para quês” por trás deles, para ver os padrões e relações entre eles, e para compreender o presente no contexto da história. (Wurman, 1990, p. 37, tradução nossa).
}

Jornais selecionam e ajudam na seleção de informações de duas formas. A primeira é a própria decisão sobre o que é notícia e deve ter espaço no jornal ${ }^{30}$ - baseando-se em critérios de noticiabilidade ${ }^{31}$.

\footnotetext{
29 Essa definição comum tem adeptos como Blake e Haroldsen (1977, p. 57), que, por sua vez, citam Charnley (1966). 30 O gatekeeping contemporâneo é limitado pela maior oferta de informação permitida pelas novas tecnologias e pela tendência de veículos voltados a públicos específicos, ou mesmo a personalização de portais eletrônicos de notícias.

31 Erbolato (1984, p. 55) cita nada menos que 24 critérios para a escolha das notícias. Já Blake e Haroldsen (1977, p. 57) resumem a lista em quatro critérios: a) o local onde ocorreu o fato, b) o quanto o acontecimento afeta o público, c) a importância dos personagens que nele intervêm e d) comparação com os demais acontecimentos do mesmo momento.
} 
A diagramação das notícias também desempenha função de organização. Nos veículos impressos $^{32}$, a hierarquização pode ser percebida pelo espaço reservado a cada notícia e sua disposição no caderno (capa, páginas pares e ímpares) e na página (acima ou abaixo da dobra).

c) Explicação

A fragmentação da informação - e também a sua saturação - dificulta, além da percepção, o entendimento das relações entre os acontecimentos. Por isso, ao mesmo tempo em que opera isolando um acontecimento da realidade e transformando-o em notícia, o jornalismo também deve recontextualizar as notícias entre si e em relação ao leitor.

Wurman (1990, p. 171) defende que o processo comunicativo depende do agrupamento de ideias, gerando comparações e conexões. O caso do jornalismo impresso é ainda mais significativo nessa função devido à limitação de sua periodicidade.

Atualmente, o leitor dispõe de múltiplas fontes de informação - e não mais de um único trovador medieval. O jornalismo eletrônico ${ }^{33}$ é instantâneo; o jornalismo impresso é submetido à periodicidade de sua produção e distribuição. $\mathrm{O}$ jornal impresso destaca relatos sobre acontecimentos da véspera, que já foram amplamente distribuídos ${ }^{34} \mathrm{em}_{\text {outras mídias. }}$

Com a perda da atualidade e da novidade do acontecimento, ganha espaço entre os veículos impressos o jornalismo de profundidade, buscando mais análise e mais explicações.

\subsection{O ESTILO JORNALÍ́STICO}

Segundo Keeble (1995, p. 86), a linguagem jornalística atual não é natural, mas um "produto de séculos de evolução linguística” que apresenta ritmo, tom e vocabulário próprios.

No Brasil, o texto dos jornais começou a ganhar a forma que conhecemos atualmente em meados do século $20^{35}$. Nessa época, "a linguagem pomposa dos literatos" (Rodrigues, 2003, p. 97) foi deixada de lado, sendo substituída pela "busca por objetividade e informação". A autora relaciona essa mudança estilística às alterações que ocorriam na organização das empresas de comunicação. Também nesse período, as empresas brasileiras de comunicação começaram a incorporar manuais e guias de estilo, já conhecidos em veículos estrangeiros. A adoção teria dois propósitos: uniformizar as técnicas de redação e resolver questões orto-

32 Noticiários eletrônicos também hierarquizam e organizam notícias, mas esse processo é modificado pelo valor dado à novidade. Acontecimentos do "último segundo" podem ganhar destaque apenas por serem os mais recentes. 33 Muitos sites de notícias funcionam em tempo real; o rádio e a televisão frequentemente possuem horários para seus noticiários, mas podem fazer uso de uma interrupção da programação.

34 Para Erbolato (1984, p. 28), os noticiários no rádio e na televisão tornaram desnecessárias as “edições especiais" do jornal impresso. $\mathrm{O}$ autor também credita às mídias eletrônicas o fim do "furo" no jornal impresso - mas ele ainda ocorre, como resultado do jornalismo investigativo.

35 Segundo Kovach e Rosenstiel (2003, p. 115), a busca pela objetividade surgiu no jornalismo já no início do século 20, contrapondo-se ao "realismo" predominante do século anterior, quando a precisão começava a ser valorizada. 


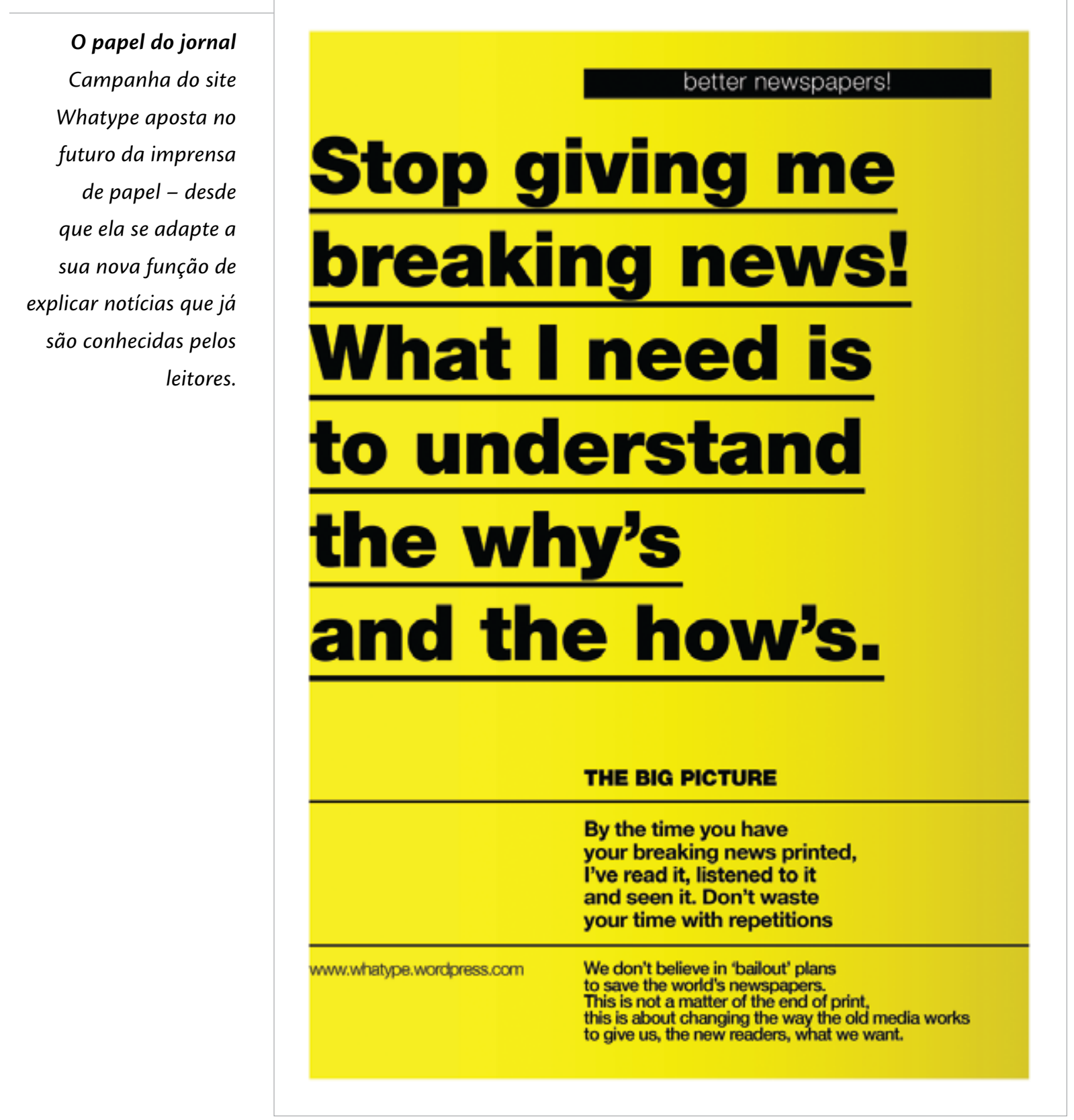

gráficas (Lage, 1985, p. 50). As orientações contidas nesses manuais refletem os princípios de clareza e objetividade considerados característicos do texto jornalístico.

O Manual de redação e estilo de O Estado de S. Paulo inicia suas "instruções gerais" recomendando: "Seja claro, preciso, direto, objetivo e conciso" (1997, p. 15). O propósito seria o de facilitar a compreensão do texto pelo leitor. O Manual de estilo da Editora Abril também prega "clareza na linguagem, precisão na informações - e bom gosto" (1990, p. 11) para que o texto possa ser lido com prazer.

De forma geral, objetividade, precisão, concisão e clareza estão entre os elementos mais comuns das instruções sobre textos informativos para jornais. 
a) Objetividade ${ }^{36}$

O Manual de redação e estilo de O Estado de S. Paulo instrui o jornalista a fazer "textos imparciais e objetivos. Não exponha opiniões, mas fatos, para que o leitor tire delas suas próprias conclusões" (1997, p. 17). Similarmente, o Manual da redação: Folha de S. Paulo defende que "a busca pela objetividade jornalística e distanciamento crítico são fundamentais para garantir a lucidez quanto ao fato e seus desdobramentos concretos" (2006, p. 22). Quanto à objetividade, o manual reconhece que ela "não existe (...) em jornalismo" (2006, p. 46), mas reforça que o jornalista tem a "obrigação de ser o mais objetivo possível" (2006, p. 46).

Para Lage (1985, p. 40), a proposta de objetividade do texto jornalístico se relaciona com sua atuação em um processo de comunicação no qual um emissor se dirige a grande número de receptores. "Por isso, os adjetivos testemunhais e as aferições subjetivas devem ser eliminados. (...) A norma é substituir tais expressões por dados que permitam ao leitor ou ouvinte fazer sua própria avaliação”.

Kovach e Rosenstiel (2003, p. 116), no entanto, consideram que o conceito de objetividade é mal compreendido atualmente: "no conceito original o método é objetivo, e não o jornalista”. Essa visão dá conta do fato de que o jornalista realiza escolhas ao longo da produção de uma notícia. Apesar de um indivíduo não poder ser objetivo, ele deve realizar o trabalho com disciplina e ética.

O chamado "texto objetivo", portanto, seria uma tentativa de se evidenciar essa prática objetiva. É com esse propósito que se adotam as regras que hoje caracterizam o texto jornalístico. Adjetivos são rejeitados para conferir neutralidade, e as notícias são contadas por meio de um modelo padronizado.

b) Precisão

A precisão está associada à correção das informações veiculadas Por isso, o Manual de redação e estilo de O Estado de S. Paulo (1997, p. 18) reforça que essa característica ajuda a conferir confiabilidade ao jornal. Com esse objetivo, os conselhos são: "confira habitualmente os nomes das pessoas, seus cargos, os números incluídos numa notícia, somas, datas, horários, enumerações”. A “exatidão" também é uma das características pedidas no Manual da redação: Folha de S. Paulo (2006, p. 20) na apresentação dos fatos.

Kovach e Rosenstiel (2003, p. 69-70) argumentam que "simplesmente trabalhar com precisão, anotando direito nomes e datas" não é suficiente, pois dados exatos nem sempre representam os fatos com veracidade. Entretanto, reconhecem que ela é a "fundação sobre a qual tudo o mais se sustenta: contexto, interpretação, debate e toda a comunicação pública”.

Se a objetividade jornalística deve estar no método, e não simplesmente no texto, o procedimento do jornalista deve seguir critérios que garantam seu compromisso com a verdade - e a precisão integra esse processo. 


\section{c) Clareza}

No Manual de redação e estilo de O Estado de S. Paulo (1997, p. 15), o estilo jornalístico é descrito como "um meio-termo entre a linguagem literária e a falada". Recomenda-se também a busca pela simplicidade, condição para que um texto possa ser compreendido por todos os leitores. A simplicidade também está entre as "quatro ${ }^{37}$ qualidades básicas" recomendadas no Manual de estilo da Editora Abril (1990, p. 15), que tem como objetivo oferecer "textos bem escritos, atraentes e legíveis".

A clareza do texto jornalístico depende de ações como a escolha de vocabulário e a organização dos períodos - sempre em ordem direta. "No texto jornalístico o que se lê é a informação; ninguém compra um jornal, por exemplo, para 'saborear' as palavras, para deleitar-se com metáforas e outras figuras de linguagem” (Nunes, 2003, p. 10). É importante também evitar a ambiguidade, já que "um dos piores inimigos da informação é o duplo sentido, que deixa o leitor desorientado" (Nunes, 2003, p. 44).

\section{d) Concisão}

O Manual da redação: Folha de S. Paulo (2006, p. 20) recomenda que "toda reportagem deve ser iniciada com a informação que mais interessa ao leitor e ao debate público (o lide ${ }^{3^{8}}$ )". Também no Manual de redação e estilo de O Estado de S. Paulo (1997, p. 18), uma das instruções é de que se disponha "as informações em ordem decrescente de importância (princípio da pirâmide invertida), para que, no caso de qualquer necessidade de corte no texto, os últimos parágrafos possam ser suprimidos, de preferência”.

Embora o "corte pelo pé" seja menos definitivo com a editoração eletrônica, a manutenção da pirâmide invertida se relaciona com o fato de que muitas leituras não avançam além dos primeiros parágrafos. A preocupação com o tempo destinado para a leitura do jornal também é contemplada nos manuais - o Manual de Redação de Redação e Estilo O Globo (1993, p. 15), por exemplo, considera a concisão como um dos requisitos de um bom texto "para não desperdiçar nem o tempo [do leitor] nem o espaço do jornal".

Comassetto (2003, p. 55) acredita que a pirâmide invertida mostrou-se uma estrutura mais eficaz para a transmissão de notícias. Alguns também estudos indicam que esse formato promove "melhor compreensão e memorização cognitiva da notícia", porque confere ao leitor as informações essenciais para acompanhar o desenrolar mais detalhado da história.

Apesar da popularização do formato, Kovach e Rosenstiel (2003, p. 226-227) defendem que é possível oferecer uma história bem escrita sem utilizar a pirâmide invertida - mas isso "exige tempo". Para os autores, o jornalista deve procurar transmitir as informações de forma interessante e relevante. Jornalismo seria, portanto, contar uma história com a finalidade de "fornecer às pessoas informação que precisam para entender o mundo".

37 As outras três características são precisão, bom gosto e simplicidade.

38 Em volume didático, voltado a estudantes de jornalismo, Marques de Melo (1972) exemplifica diversos tipos de lead. O lead integral deveria responder às perguntas quem?, o quê?, quando?, como?, onde? e por quê?. 
A visão do jornalismo como uma mistura de se contar histórias e transmitir informações também se relaciona à ideia de que narrativas são um formato privilegiado para transmitir e memorizar fatos.

\subsection{A imagem no jornalismo}

As características pelas quais o texto jornalístico é conhecido atualmente representam as evoluções mais recentes desse gênero. Lustosa (1996, p. 67) considera que o jornalismo brasileiro passou por cinco fases de codificação da notícia a partir da implantação da imprensa no país, em 1808. O jornalismo mais opinativo deu espaço ao informativo na terceira fase, por volta do final do século 19. A linguagem mais enxuta e concisa marcam a configuração surgida a partir da década de 1930 - fase marcada pela introdução do lead e do manual de redação no Diário Carioca em 1950, com o trabalho de Pompeu de Sousa (Mendez, 2006).

A fase atual, iniciada em 1969, se relaciona com a cultura visual da sociedade e com o desenvolvimento das tecnologias de edição e impressão. A técnica de xilogravura já possibilitava a reprodução de imagens com qualidade e foi bastante utilizada até o século 19. No jornalismo, entretanto, o tempo necessário para a gravação das matrizes contrariava a agilidade exigida para a transmissão de notícias - embora ela também fosse utilizada. A partir do final do século 18 , a invenção da litografia permitiu maior articulação entre texto e imagem também nos jornais.

\section{O que o leitor lê}

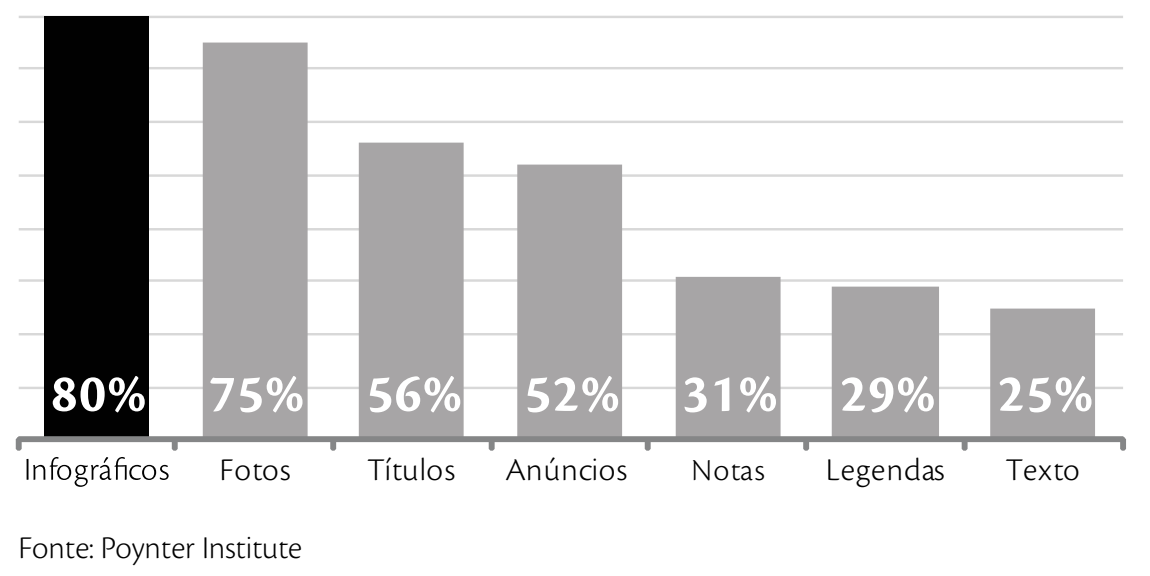

\section{Leituras medidas}

Com dados da pesquisa Eyetracker (Poynter Institute, 2007), Kanno (2008) defende que indices de leitura de elementos imagéticos superam os de elementos textuais.

Outro marco importante do uso de imagens nos veículos de comunicação impressos foi a invenção da fotografia, na década de 1820 , e sua reprodução em jornais, a partir de $1880^{39}$. De-

39 A confecção do clichê para a impressão de fotografias em jornais ocorreu somente com a descoberta do negativo (Arbach, 2007, p. 120). Entretanto, a fotografia já influenciava a ilustração jornalística em meados do século 19, 
vido ao modo como é produzida, a foto foi vista como uma prova material ${ }^{40}$ de que um fato realmente aconteceu, em concordância com a tendência mais informativa dos relatos jornalísticos da época. Essa característica "deslocou para a foto seu aspecto documental, enquanto que para o desenho permaneceu apenas seu caráter opinativo” (Arbach, 2007, p. 113).

A ampliação do uso de imagens nos jornais, no século 19, coincidiu com a difusão dos veículos impressos entre a população urbana semi-alfabetizada. No Brasil, o mesmo processo ocorreu na virada para o século 20, quando a "imagem seria a forma mais adequada de propagação de mensagens para uma população em sua maior parte analfabeta” (Simioni, 2002, p. 82).

Estudos recentes indicam ainda que os elementos imagéticos ainda apresentam maior índice de leitura que os elementos textuais dos jornais. Os olhos dos leitores realizam fixações nas fotografias, mesmo que não se preocupem com as legendas. A ação de "ler o jornal” seria, para muitas pessoas, a assimilação do conteúdo elaborado na forma de imagens.

Embora reconheça o "valor referencial" dos elementos analógicos ${ }^{41}$ - fotografias, ilustrações, charges, cartoons - e sua função de fixação, Lage $(1985$, p. 6) considera que sua sintaxe seja "relativamente pobre, e isso os torna passíveis de conceituação variável, ambíguos como a própria observação da realidade”. Eles dependeriam de legendas e títulos para que seus significados se tornassem mais claros.

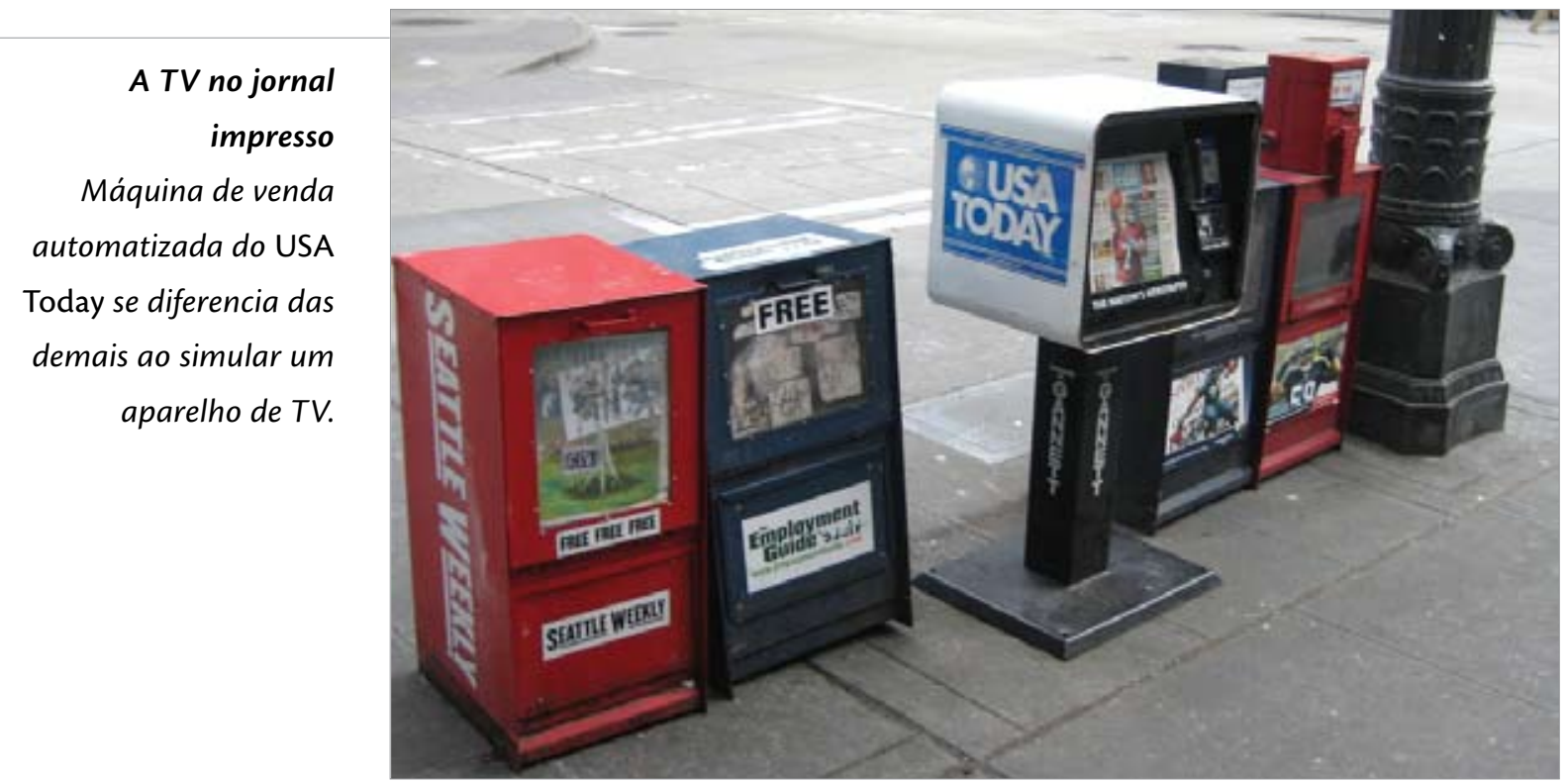

Quando Lustosa (1996, p. 73) relaciona a "notícia plástica ou iconográfica” à informatização dos veículos impressos e à "reprodução pelos jornais e revistas do modelo televisivo",

conferindo-lhe mais detalhes e realismo.

40 Atualmente, essa visão pode ser considerada ingênua. A imagem fotográfica é subjetiva e pode ser manipulada, desde a escolha do objeto e do enquadramento até sua edição e uso.

41 Para o autor, os níveis de informação do jornal incluem sistema analógico, projeto gráfico e sistema linguístico. 
também parece haver certo desdém ao valor comunicativo da imagem. O jornal USA Today, conhecido pelo apelo visual e por suas máquinas de venda automatizada que tentam se parecer com um aparelho de televisão, ficou conhecido como "McPaper".

Para Arbach (2007, p. 135), no entanto, o papel da ilustração é considerado secundário ao do texto na comunicação impressa devido a uma distinção de classes - a alfabetização e os livros eram privilégios da aristocracia - e também à ideia de que, como a compreensão pela imagem é imediata, há menor esforço intelectual do artista que produz a imagem do que do autor que elabora o texto.

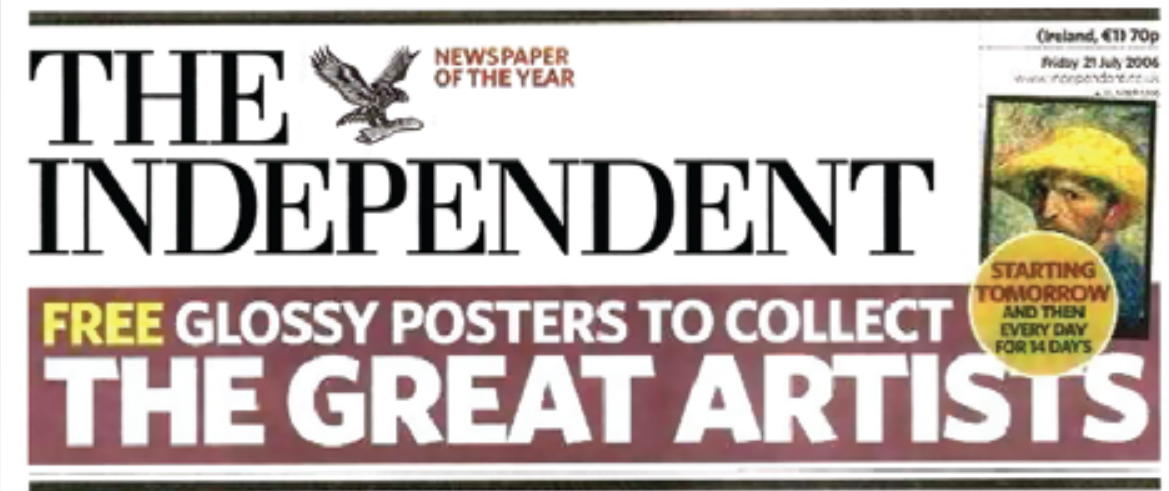
A informação visual
Capa do jornal britânico
The Independent (21/
jul./2006) causa impacto ao utilizar composição gráfica para transmitir uma informação.

As a humanitarian disaster looms, Britain and US are left exposed by refusing to endorse UN's demand for an end to hostilities

\section{Middle East: Who backs immediate ceasefire?}

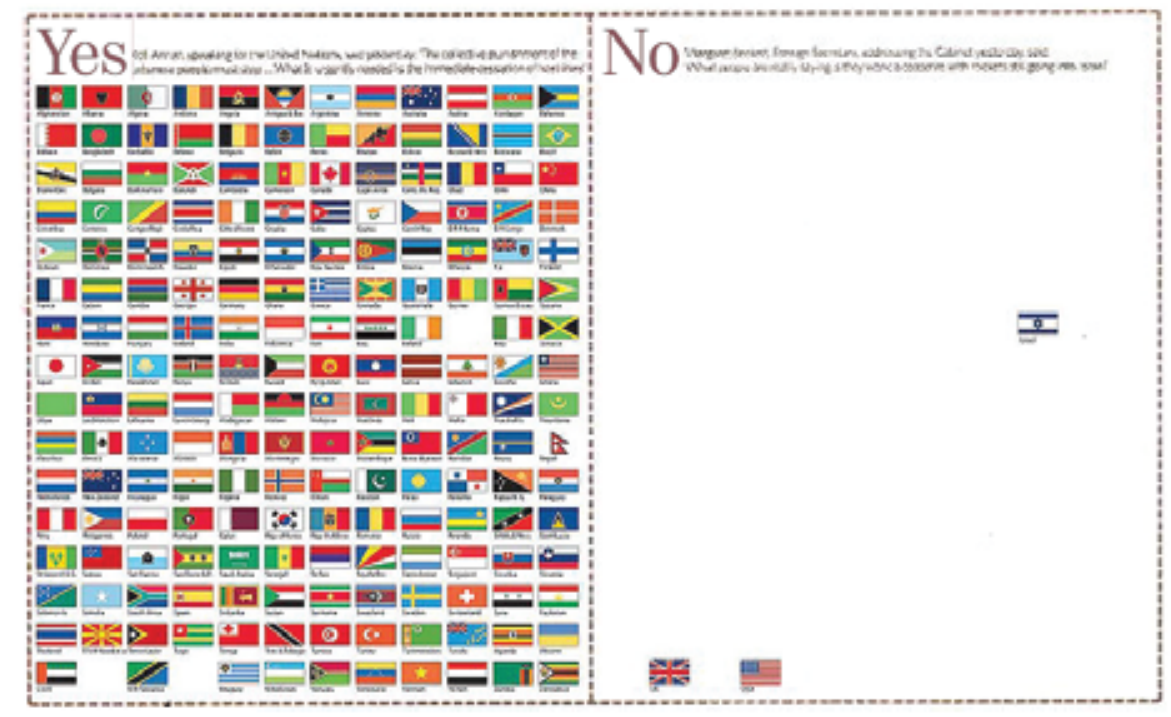

O aprimoramento da comunicação visual possibilita que elementos imagéticos comuniquem informação e opinião. A “rápida assimilação” da imagem não tem como única finalida- 
de ou efeito a facilitação da leitura e a simplificação do conteúdo, mas pode também causar um impacto diferente do transmitido por palavras.

Segundo Dondis (2007, p. 131-132), a mensagem existe na interação entre forma e conteúdo e entre emissor (designer) e receptor (observador). "A forma é afetada pelo conteúdo; o conteúdo é afetado pela forma”. E o observador modifica a mensagem, mas o designer pode usar a composição para "controlar a reinterpretação de uma mensagem visual por parte de quem a recebe”.

Assim, uma capa visual do jornal britânico The Independent pode mostrar posicionamento com o uso da técnica visual do contraste - "um poderoso instrumento de expressão, o meio para intensificar o significado, e, portanto, simplificar a comunicação” (Dondis, 2007, p. 108). 


\section{INFORMAÇÃO PELO DESIGN}

Uma das definições mais populares para design ${ }^{42}$ da informação é a de Horn (2000, p. 15, tradução nossa): "design da informação é definido como a arte e ciência de preparar a informação para que ela possa ser utilizada por seres humanos com eficácia e eficiência”. Sua aplicação não se restringe ao design gráfico e à comunicação visual, mas, nesse campo, seu objetivo principal é o desenvolvimento de documentos que permitam a recuperação rápida e precisa de informação.

Para Wildbur e Burke (1998, p. 6, tradução nossa), “o design da informação no sentido mais amplo consiste na seleção, organização e apresentação da informação para um público determinado". Sua função é comunicar dados de forma eficiente "para permitir que o usuário tome algum tipo de decisão". Isso significa que a finalidade do design da informação não se encerra na recuperação dos dados, mas sim no entendimento da informação.

O debate sobre o design da informação é considerado recente - teria se organizado somente em meados da década de $1990^{43}$. Dessa forma, "a teoria é imprecisa e os estudos de caso são escassos. Poucos estudos de design da informação foram realizados para sustentar qualquer generalização ampla sobre sua prática” (Jacobson, 2000, p. 3, tradução nossa).

Uma das dificuldades de se estabelecer uma teoria única sobre design da informação é a diversidade de práticas abrigadas nessa disciplina. Uma tentativa de teorização do design da informação parte de Dervin (2000), que sugere uma perspectiva de sense-making - isto é, enfatizando a forma como as pessoas estabelecem conexões e encontram sentido na realidade. Um dos princípios dessa teoria é a definição de informação como artificial e projetada. Como consequência, "design da informação é, na realidade, metadesign: design sobre design, design para ajudar pessoas a fazer e desfazer suas próprias informações, seu próprio sentido" (Dervin, 200o, p. 43, tradução nossa).

Embora a aplicação do pensamento de Dervin a todos os contextos do design da informação possa ser questionada, ela encontra eco em uma de suas porções: a visualização da informação. Costa (1998, p. 24, tradução nossa) define a visualização como "um ato cujo propósito é tornar visível algo que não o é. E cuja finalidade é tornar compreensível algo que não é possível atingir de outro modo (ou que seria mais difícil e menos exato)”. Tornar algo compreensível implica em que o receptor seja capaz de realizar conexões entre os dados - o papel do designer da informação, portanto, é ajudar os receptores a encontrar o sentido comunicado.

42 De acordo com Denis (2000, p. 16), a palavra design, na língua inglesa, "se refere tanto à ideia de plano, desígnio, intenção, quanto à de configuração, arranjo, estrutura" - ambiguidade já presente em sua origem latina (designare). 43 A prática também se intensificou nas últimas décadas devido ao significativo aumento da quantidade de informação à qual somos expostos diariamente - gerando a tal ansiedade de informação de Wurman (1990). 
Para Cairo (2008, p. 27, tradução nossa), "a visualização lida com a apresentação diagramática de dados, de sua transformação visual em informação, para facilitar sua compreensão, e bebe das artes e técnicas da comunicação gráfica”. Por meio do design da informação - e, mais especificamente, da visualização da informação, os dados são transformados em informação e possibilitam a compreensão e memorização (pelo receptor) para que essa informação seja finalmente convertida em conhecimento.

\subsection{PRINCÍPIOS DO DESIGN DA INFORMAÇÃo}

O design da informação é uma disciplina que se relaciona com diversos outros campos científicos. Cairo (2008, p. 24) reconhece contribuições de áreas como psicologia cognitiva e técnicas como cartografia, esquemática e representação estatística.

Em breve levantamento histórico, Horn (200o, p. 17) lista influências do design da informação em categorias como "inventores", "sistematizadores", "estéticos", "popularizadores" e "pesquisadores”. Por isso, os princípios que orientam o design da informação ${ }^{44}$ foram levantados nos textos de autores considerados fundamentais.

a) William Playfair

A biografia do engenheiro escocês William Playfair inclui desde o período em que "convivia com figuras importantes da época em ciência, engenharia, negócios e política” durante sua juventude até um episódio de "tentativa de extorsão" (Wainer e Spence, 2005, p. 6-8), em seus anos finais. Mas seu legado, reconhecido séculos após sua morte, é a invenção de diagramas como o gráfico de linha e de barras para representar dados econômicos, além do gráfico de área para representações de parte e todo.

A inovação de Playfair foi publicada pela primeira vez em 1786, em obra chamada The Commercial and Political Atlas. Dezesseis anos depois, quando publicou a terceira edição, Playfair escreveu ter sido "realmente o primeiro a aplicar os princípios da geometria para assuntos financeiros” (Playfair, 2005, p. viii, tradução nossa).

Playfair tenta explicar o conceito da representação gráfica de valores econômicos fazendo um paralelo com uma pilha de moedas:

Suponha que o dinheiro que um homem recebeu em negociações fosse todo em guinéus, e que toda noite ele fizesse uma pilha única com todos os guinéus recebidos durante o dia. Cada pilha representaria um dia, e sua altura seria proporcional aos recebimentos daquele dia; então, por essa

44 Considerando-se a diversidade dos campos que dão suporte ao design da informação, não é surpreendente encontrar pensamentos discordantes entre os autores citados. A convivência dessa diversidade de princípios é bem resolvida por Tufte (2007, p. 191, tradução nossa) que, ao se referir a sua própria teoria, defende que "os princípios não devem ser aplicados de forma rígida ou impertinente; eles não são certezas lógicas ou matemáticas, e é melhor violar qualquer princípio do que fazer marcas sem graça ou elegância no papel”. 
simples operação, tempo, proporção e quantidade seriam todos fisicamente combinados. (Playfair, 2005, p. xi, tradução nossa).

Além de eventuais deslizes na gravação das matrizes de impressão4s, o traçado dos gráficos de Playfair deixa a desejar em termos de acurácia (Wainer e Spence, 2005, p. 17). Entretanto, ele defende seus gráficos como um método cuja finalidade não é maior precisão que aquela conferida por dígitos, mas sim "dar uma ideia mais simples e permanente do gradativo progresso e quantidades comparativas, em diferentes períodos” (Playfair, 2005, p. $\mathrm{x}$, tradução nossa).

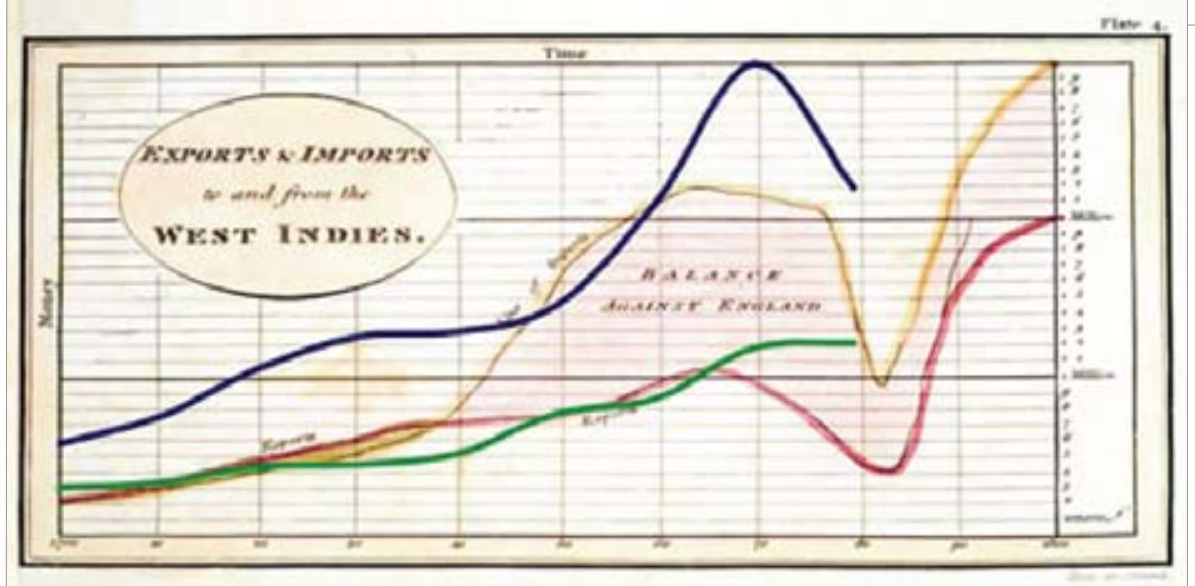

\section{Exportações e}

importações

Traçado de Spence

e Weiner (2005)

sobreposto a gráfico

publicado por Playfair

(1801) denuncia pequeno

cuidado com precisão.

Playfair também considera que o olho tem a capacidade de estimar proporções rapidamente, de forma que proporção, progressão e quantidade são absorvidos em um ato de visão e um ato de memória.

\section{b) William S. Cleveland}

Um dos principais estudos sobre a representação gráfica de dados foi realizado por Cleveland (1994, p. 1, tradução nossa), argumentando que "não importam a escolha inteligente da informação ou a codificação tecnologicamente impressionante; uma visualização falha se a decodificação falhar”.

Para que a representação dos dados ajude a revelar padrões e detalhes, é necessário escolher o gráfico mais adequado. Com base em estudos sobre percepção visual, Cleveland reconhece três operações visuais para o reconhecimento de padrões em gráficos: detecção (ou seja, o reconhecimento visual de um elemento), montagem (o agrupamento visual dos elementos gráficos detectados) e estimativa (a avaliação visual e comparação dos valores quantitativos).

45 Segundo Wainer e Spence (2005, p. 13), os gráficos do Atlas eram impressos com o uso de gravações em cobre muitas delas feitas pelo próprio Playfair - e coloridos manualmente. 


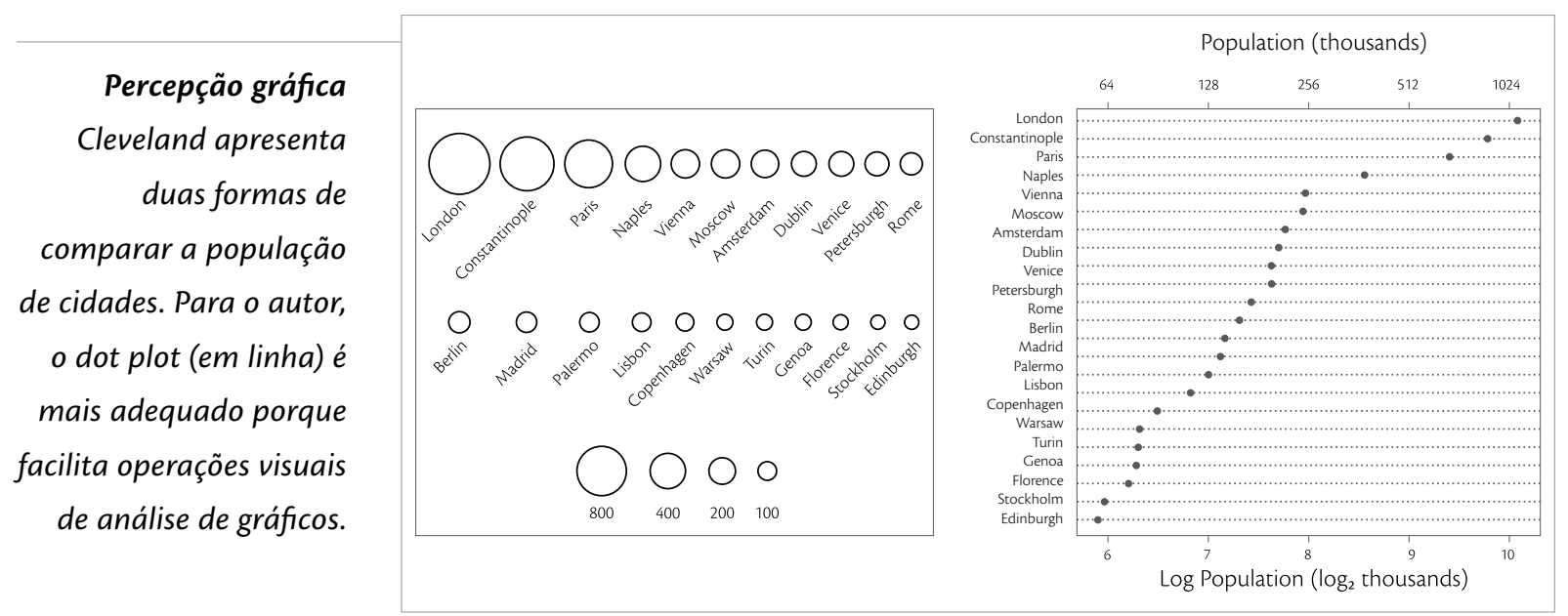

Como a finalidade da representação gráfica dos dados é a percepção dos padrões, Cleveland (1994, p. 117) também destaca a importância do gráfico para permitir ou facilitar que uma informação seja notada.

Outro princípio defendido por Cleveland é o de que os dados são o motivo da existência de um gráfico e, portanto, devem ser os elementos proeminentes - apesar das tentações relacionadas às tecnologias de representação (Cleveland, 1994, p. 1).

c) Edward Tufte

O trabalho de Tufte é considerado um dos pilares do design da informação porque estabelece princípios para uma teoria sobre a representação de dados, principalmente os quantitativos. $\mathrm{O}$ objetivo deve ser sempre a revelação de uma informação complexa, mas com simplicidade na representação gráfica.

"A teoria da visualização da informação quantitativa consiste de princípios que geram opções de design e guiam escolhas entre as opções” (Tufte, 2007, p. 191, tradução nossa). O princípio fundamental dessa teoria é: "acima de tudo, mostre os dados” (2007, p. 92, tradução nossa).

A ênfase de Tufte está na eficiência da representação, eliminando-se traços desnecessários. O autor compara o trabalho do designer de gráficos estatísticos ao de um editor de texto, removendo palavras e traços desnecessários para enfatizar a informação (Tufte, 2007, p. 100). Assim, o autor seleciona de um gráfico de barras tradicional somente os traços que realmente contêm os dados.

Esse posicionamento pode ser questionado - talvez a eficácia comunicativa exija um pouco mais de redundância. Nesse ponto, encontram-se divergências entre Tufte e Cleveland ${ }^{46}$, já que este último busca sempre tornar a informação mais clara e recuperável, mesmo que isso aumente a quantidade de elementos visuais representados. 


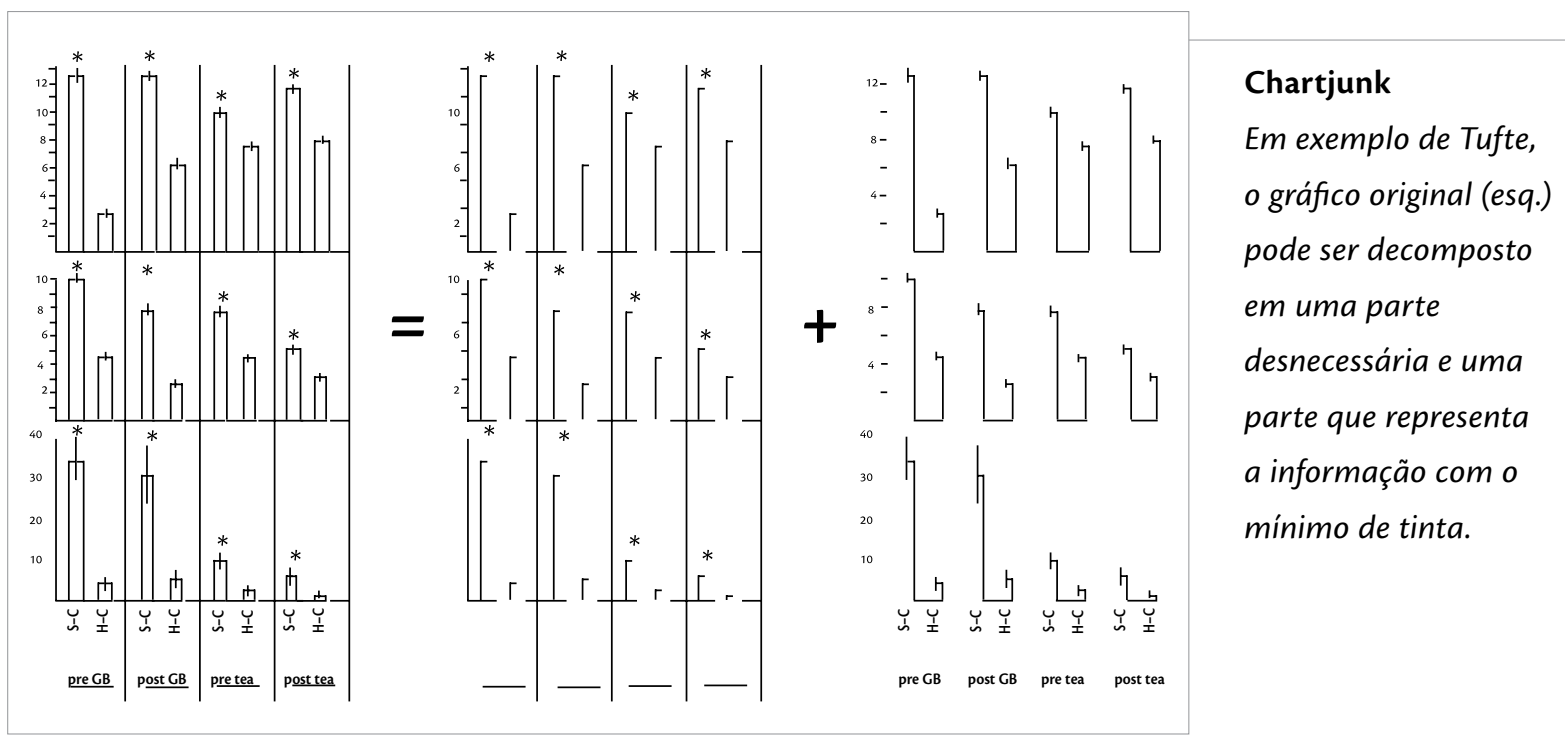

Mas o combate ao chartjunk parece ser uma tentativa de se remediar a falta de confiança do público em gráficos surgida após décadas de uso inadequado. Tufte (2007, p. 87) argumenta que a competência gráfica integra habilidades substantivas, estatísticas e artísticas - mas o trabalho realizado por veículos de comunicação frequentemente se limita à arte.

Igualmente importante é sua crítica à distorção dos dados na representação gráfica. Tufte sugere a realização de testes para se conhecer o efeito visual percebido em cada tipo de gráfico - um exemplo é a descoberta de que nossa percepção sobre o aumento da área de um círculo é menos precisa (representando outro problema no gráfico apontado por Cleveland). Também pede cuidados com representações bidimensionais de valores unidimensionais, que podem levar à distorção visual das variações. Finalmente, reforça a necessidade de contexto dos dados representados.

A integração entre dados e texto também é defendida por Tufte (2007, p. 180), com a justificativa de que as palavras ajudam os receptores. Palavras e gráficos seriam mecanismos diferentes que dividem a mesma função de apresentação da informação, de forma que rótulos verbais não são considerados desperdício de tinta: eles ajudam a reduzir a ambiguidade e a distorção na representação gráfica.

d) Jacques Bertin

A neográfica não é arte e tem como finalidade a imagem operacional (em oposição à figurativa) e monossêmica. Para Bertin (1986, p. 2), a representação adequada de dados permite a ação ${ }^{47}$ do receptor. "Decidir é escolher, e escolher é, de início, informar-se".

Bertin (1986, p. 7) propôs sistematizar a construção de gráficos de informação. Suas ideias partem do princípio de que a informação útil não está nas estatísticas, mas sim nas relações

47 A ideia de gerar entendimento para possibilitar a tomada de decisões encontra eco na definição de design da informação para Wildbur e Blake, assim como na concepção de jornalismo de Kovach e Rosenstiel. 
do conjunto. "Os olhos são feitos para perceber semelhanças e conjuntos, e não somente sinais, palavras e número".

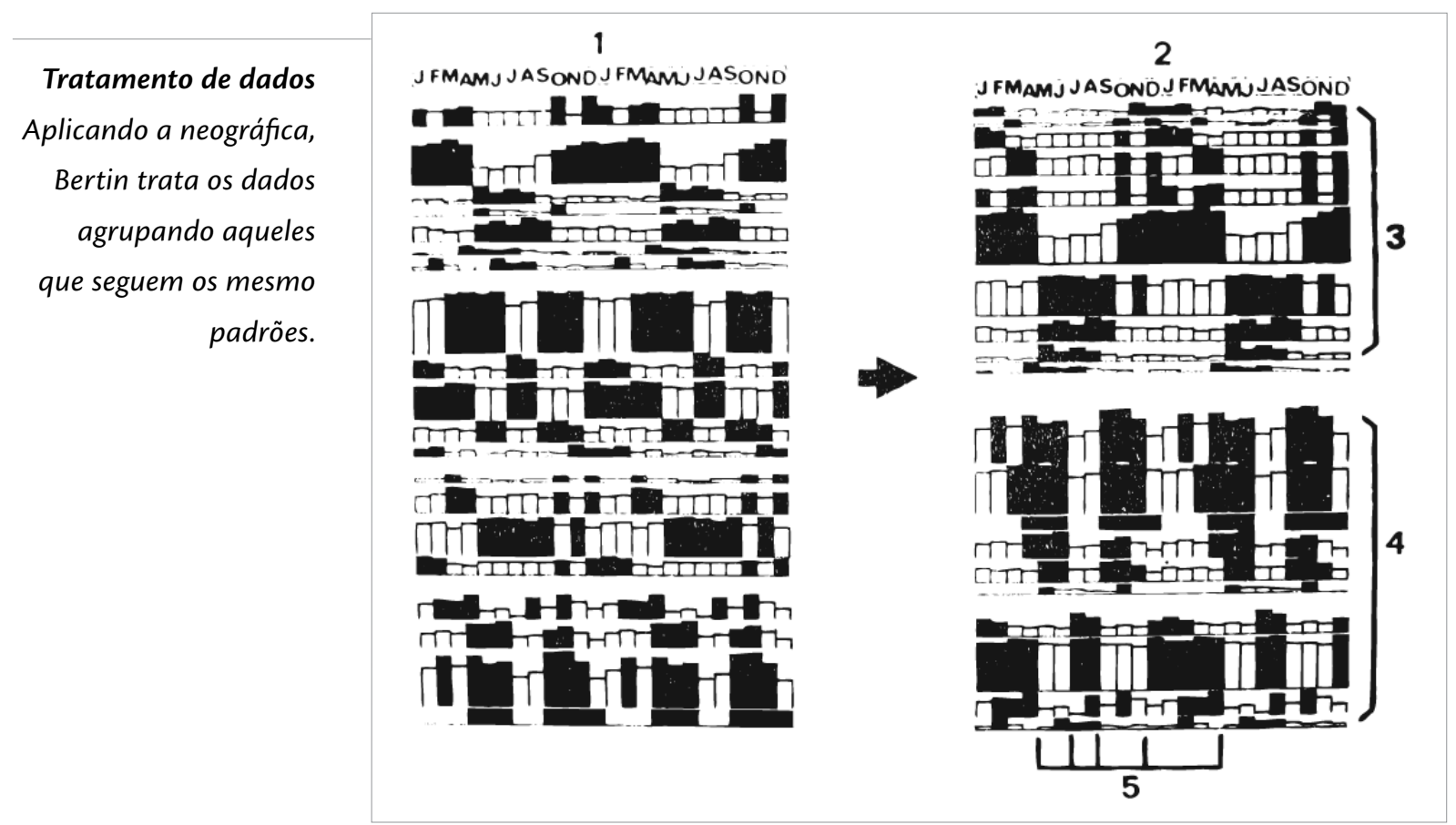

A percepção gráfica aconteceria em dois tempos. O primeiro, “identificação externa”, responde à pergunta "do que se trata?" através do isolamento dos conjuntos. O segundo, "identificação interna”, detecta as relações entre o que foi identificado no primeiro momento.

A construção gráfica respeita as operações de percepção. As estatísticas relacionadas a um problema (a pergunta) levantado no início do processo geram um quadro, e esse quadro recebe tratamento gráfico. As respostas surgem após a manipulação do gráfico, que o organiza e o simplifica por meio de agrupamentos. Dessa forma, as informações contidas nos dados estatísticos tornam-se visíveis, facilitando a compreensão e, como consequência, a decisão.

Assim como Cleveland, Bertin (1986, p. 47) lida essencialmente com representação de dados científicos - chegando a criticar a imprensa ${ }^{48}$ por "publicar somente as particularidades não significantes”.

e) Nigel Holmes

Caracterizado por Horn (2001, p. 21) como um "popularizador" do design da informação, Nigel Holmes ficou conhecido pelo uso do design e da ilustração em gráficos informativos

48 Entretanto, a diferenciação entre a neográfica de tratamento (na qual não se conhece o que será revelado) e a neográfica de comunicação (na qual se busca um meio para a transmissão e fixação de uma informação conhecida) pode indicar aplicação do sistema na apuração jornalística (tratamento), para a análise de dados e descoberta das informações inseridas no conjunto, e também na apresentação (comunicação), para a transmissão da informação ao leitor. 


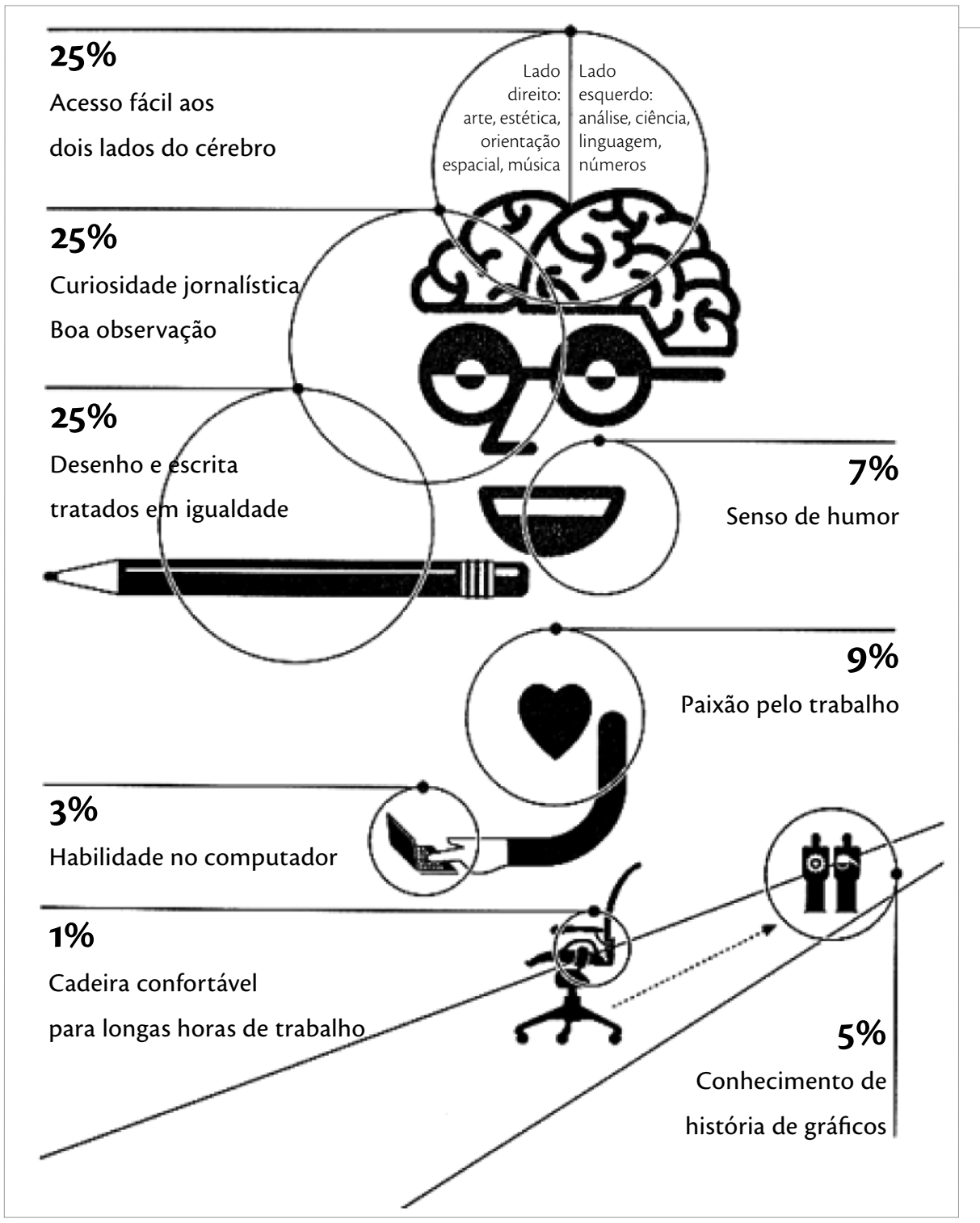

O que é preciso para ser um designer da informação? Auto-retrato de Nigel Holmes apresenta anatomia de um infografista.

da revista Time, com o objetivo de atrair a atenção e aumentar os índices de leitura. Segundo Holmes, muitos leitores têm medo de dígitos, e a função do criador de diagramas seria revelar os segredos dos números.

\footnotetext{
Um simples diagrama não é mais que um conjunto de estatísticas tornadas visíveis. Ele mostra o que aconteceu no passado e o que pode acontecer no futuro. Mas também pode fazer mais. Ele pode envolver o receptor ao capturar sua imaginação. Ele pode interpretar os valores, além de representá-los. (Holmes, 1984, p. 9, tradução nossa)
}

Apesar de defender elementos ilustrativos em diagramas informativos, Holmes (1984, p. 72) ressalta que essa criatividade visual só deve ser trabalhada se o artista compreende e respeita que a função principal é transmitir dados estatísticos. 
Além disso, ele também reforça que seu objetivo e da maioria dos editores é de que o público "tenha melhor entendimento sobre qualquer que seja o assunto do gráfico" (Heller, 2006 , p. 18, tradução nossa). Nesse raciocínio, Holmes vê com cuidado os gráficos muito complexos - no caso de um jornal diário, espera-se que a compreensão de seu conteúdo não se estenda além da curta vida do veículo.

\subsection{O DESIGN GRÁFICO E O DESIGN DA INFORMAÇÃO NO JORNALISMO}

A forma como observamos uma página de texto é definida culturalmente. No que chamamos de Ocidente, nossos olhos seguem da esquerda para a direita - sentido no qual escrevemos - e de cima para baixo. Isso faz com que certas áreas de uma página recebam mais atenção do leitor, tornando necessária a utilização de artifícios para criar pontos de atração nas áreas menos valorizadas.

Segundo García (1984, p. 56, tradução nossa), a diagramação de um periódico tem papel duplo: "capturar a atenção do leitor no momento em que vê a página" e "criar o interesse visual necessário para que os olhos do leitor não se afastem da página”. Também é função da diagramação e da paginação representar visualmente a hierarquia dos assuntos tratados em um jornal.

\section{Como o leitor lê \\ A pesquisa Eyetracker \\ também aponta que \\ a organização de \\ elementos verbais $e$ \\ visuais modifica a \\ leitura. Para Kanno \\ (2008), a integração \\ aumenta o indice de}

leitura.

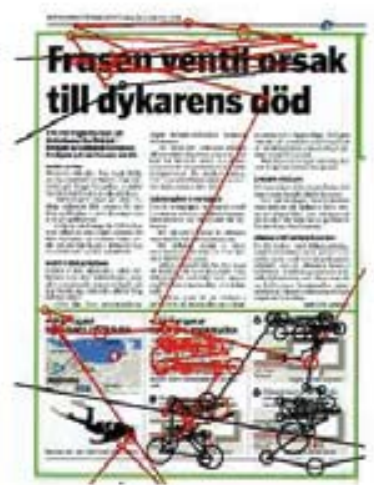

Narrativa tradicional

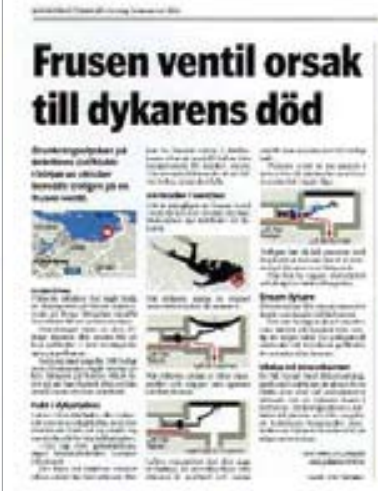

Integração verbal/visual

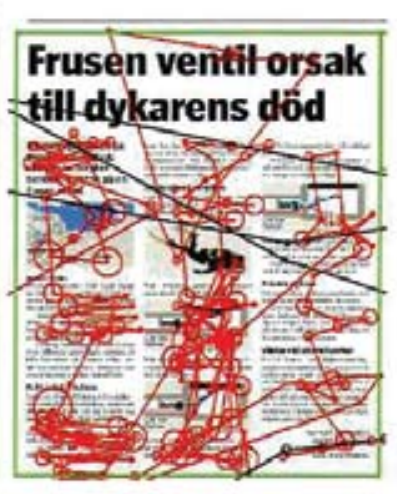

Fonte: Poynter Institute

Pesquisa do instituto Poynter (2007) apontou que a organização dos elementos de uma página impressa define o modo como ela será lida. Manchetes e fotos ${ }^{49}$ são os primeiros

49 Outra descoberta do estudo é que imagens documentais chamam mais a atenção do que fotos montadas ou posadas. Isso significa que o leitor não é atraído por um elemento imagético, mas sim por elementos imagéticos que contenham (e não apenas ilustrem) uma história. De acordo com Finberg e Itule (1990, p. 183, tradução nossa), "fotografias de jornais dão aos leitores uma oportunidade de se tornarem parte do mundo, de verem coisas sobre as quais 
elementos lidos em uma página, e são também os pontos de atração nos quais o olhar se fixa. Se eles estiverem integrados ao texto, este último também receberá mais fixações do olho do leitor.

O mesmo estudo também verificou que modelos alternativos como listas, linha do tempo e sumários aumentam em 15\% a atenção dos leitores (comparada com a narrativa escrita convencional) - e esse número sobe para $30 \%$ no caso dos jornais em formato standard. Outra descoberta da pesquisa foi que esses elementos ajudaram leitores a compreender e recordar o que eles haviam lido.

Esses modelos alternativos de se contar uma história resultam da fragmentação da linha escrita em estruturas representando esquemas reais e mentais. A função do design da informação é recompor essa narrativa para o leitor, conquistando a atenção da linguagem visual sem causar prejuízo à informação. Esse formato é conhecido como infográfico. 



\section{UMA VISÃO SOBRE INFOGRÁFICOS}

Assim como no espanhol, o termo "infográfico" chegou ao português a partir da palavra inglesa infographics, popularizada no meio jornalístico a partir da década de 1980. Infographics, por sua vez, é uma redução da expressão information graphics.

Por causa da construção da palavra, é comum tentar decompor "infográfico” em "informação + gráficos". Também é frequente associar essa decomposição com a relação "texto + imagem”. Esse tipo de análise do termo é falha ${ }^{50}$ porque sugere que apenas o texto, e não a imagem, seja informativo.

Outra consideração contra esse tipo de definição é que uma foto impressa em um jornal geralmente é acompanhada por uma legenda verbal, formando um conjunto texto + imagem - mas isso não o transforma em um infográfico. Inversamente, diagramas informativos podem dispensar palavras ${ }^{51}$, e sumários ${ }^{52}$ essencialmente verbais são tratados como infográficos pela organização visual diferenciada, que faz uso de tarjas, numeração e composição em itens.

O surgimento da infografia dependeu de nova concepção sobre imagem e texto, que dissolveu a hierarquização entre esses elementos e modificou os modos de leitura.

\subsection{História e EVOLUÇÃo}

A presença dos infográficos na imprensa se reforçou entre as décadas de 1980 e 1990. Costumeiramente, são citados três fatores para a sistematização do seu uso nesse período: a informatização das redações - principalmente com computadores Macintosh $(1984)^{53}$-, a influência do USA Today (1982) - o jornal que, além de lido, "passou a ser mais visto" - e, finalmente, a cobertura da Guerra do Golfo (1991) - que marcou a consolidação do formato e sua disseminação nos veículos jornalísticos.

Seria exagero aceitar literalmente que

50 Cairo (2008, p. 31) faz críticas a esse tipo de "malentendido".

51 Nigel Holmes compilou uma série de diagramas sem palavras em seu livro 1, 2, 3, 4 (Wordless diagrams); são utilizados números, setas ou a ordem de leitura (esquerda para a direita, de cima para baixo) para orientar o leitor.

52 Fichas, resumos, tabelas, escores e listas estão entre elementos chamados "arte-texto". O uso de pictogramas ou ilustrações é comum, mas não necessário.

53 Para Wildbur e Burke (1998), a chegada do computador pessoal modificou o trabalho do designer porque reduziu o tempo necessário para o processo de edição. 
a história da infografia é tão antiga como a da conjunção de um texto informativo com uma imagem ${ }^{54}$, fenômeno visual que encontramos na Babilônia e no Egito, sem falar nos antigos restos de culturas primitivas em paredes de cavernas” (De Pablos, 1999, p. 19, tradução nossa).

Mas a infografia está presente no jornalismo desde bem antes dos mapas meteorológicos do USA Today. Müller-Brockmann (2001) nota que, se o jornal moderno surgiu em 1609, em 1622 já circulavam periódicos com ilustrações. Peltzer também afirma que

a informação gráfica apareceu na imprensa praticamente com os primeiros jornais, mas sempre foi considerada mais como uma arte decorativa, ou como simples complemento da informação textual do que como informação em si mesma (1992, p. 75).

Essa hierarquização entre imagem e texto não se restringia à imprensa. Barthes e Compagnon (1987, p. 205) observam que a relação era marcada por desequilíbrio: imagens alegóricas acompanhando textos de maior importância, ou textos acrescentados para especificar informações de imagens.

Já o infográfico funde o verbal ao visual. Não se trata mais de usar o texto para ajudar a decifrar a imagem, como uma legenda. Tampouco se trata de uma ilustração figurativa, feita com o propósito de adornar a página de um manuscrito, ou uma substituição do texto com propósito de transmitir os conhecimentos bíblicos à população iletrada. No infográfico, a forma é utilizada para reproduzir relações entre as ideias e para ajudar a construir narrativas.

Não há unanimidade quanto à publicação do primeiross infográfico em um jornal impresso $^{56}$. Levantamentos realizados por diversos autores ${ }^{57}$ revelam o uso de mapas e diagramas a partir do início do século 18:

- Para Cairo (2008, p. 49, tradução nossa), "as primeiras infografias da imprensa foram mapas criados por autores anônimos nos quais se intui certa falta de formação em cartografia” - manifestações mais artísticas do que jornalísticas. Um exemplo é um mapa da tentativa de invasão da baía de Cádiz por tropas britânicas, publicado pelo The Daily Courant em 22 de setembro de 1702.

- Sullivan (1987) faz referência a um mapa publicado no britânico Daily Post em 29 de março de 1740. O mapa, que representa um ataque do almirante inglês Vernon à cidade

54 Flusser (2008, p. 140) também afirma que os primeiros registros da escrita mesopotâmica tinham como função "facilitar o deciframento das imagens".

55 Além da raridade do material de pesquisa, essa definição é também dificultada pela questão da própria definição da infografia - assunto que será tratado mais à frente.

56 De acordo com Albert e Terrou (1990), as primeiras gazetas periódicas apareceram na Alemanha no final do século 16. No início do século seguinte, periódicos regulares já circulavam na Alemanha, Inglaterra, França e Suécia. 57 Sullivan, Evans e Taylor, Horn e Monmonier são citados por Peltzer (1992); por sua vez, as referências de Peltzer são citadas por De Pablos (1999) e Pereira (2006). 
de Portobello (Panamá), "contém também elementos que apontam para um aspecto narrativo, as ilustrações e letras que remetem a referências verbais" (Pereira, 2006, p. 14).

- Horn e Monmonier mencionam a ilustração “The Snake Device”, publicada originalmente no norte-americano ${ }^{58}$ Pennsylvania Gazette de 9 de maio de 1754. A gravura mostra "uma serpente cortada em oito partes, que seriam oito dos estados, então desunidos, dos atuais Estados Unidos de América” (De Pablos, 1999, p. 21).

- Para Evans e Taylor (1978), "o primeiro gráfico ou diagrama informativo publicado num meio de comunicação" (Peltzer, 1992, p. 108) teria sido um plano da casa de Isaac Blight, contando seu assassinato, com explicações no rodapé identificando os passos do assassino dentro da casa, a trajetória da bala e o local onde o corpo foi encontrado. O gráfico foi impresso na capa da edição de 7 de abril de 1806 do britânico The Times.

Entre esses exemplos, o diagrama de 1806 já trazia características modernas, aproximando-se dos infográficos atuais. Mesmo assim, Peltzer (1992, p. 109) considera que "nada se fez pela publicação de gráficos informativos nos jornais” nos 150 anos seguintes ao gráfico do Times. Segundo ele, dois fatores contribuíram para essa estagnação: as limitações tecnológicas da produção de jornais na época ${ }^{59}$ e o status $^{60}$ da alfabetização, fazendo com que o texto escrito dos jornais diferenciasse os indivíduos letrados da população analfabeta.

Mas o jornalismo já havia começado a se expandir algumas décadas antes disso. "Nos dois primeiros terços do século $19^{61}$, a imprensa fez progressos consideráveis: os jornais se multiplicaram e se diversificaram em numerosas categorias; as tiragens aumentaram" (Albert e Terrou, 1990, p. 29). Mudanças sociais, econômicas e políticas - difusão da alfabetização, aumento da população urbana e do corpo eleitoral - ampliaram o público leitor. Ao mesmo tempo, evoluções técnicas permitiram tiragens cada vez maiores, e com edições a preços mais acessíveis - além de facilitarem a produção e impressão de recursos gráficos nos jornais.

Esse século também foi marcado por um "crescimento explosivo de gráficos estatísticos e mapas temáticos" (Friendly, 2006, p. 25, tradução nossa), amparado em inovações técnicas e de representação da informação. A passos mais lentos, a infografia também se desenvolveu, incorporando as novas técnicas.

Assim, não é possível pensar a evolução dos infográficos de forma desvinculada ao desenvolvimento dos diversos aspectos ligados a sua produção e reprodução. A comunicação

58 O jornal foi aqui caracterizado como "norte-americano", embora a publicação da edição citada seja anterior à independência dos Estados Unidos.

59 Em meados do século 19, também surgiam as revistas ilustradas, mas suas periodicidades mais espaçadas possibilitavam sua publicação.

60 Essa ideia não é compartilhada por De Pablos (1999, p. 21), para quem o jornal já buscava ser mais visual desde seus primórdios porque o jornalista sempre teve como objetivo atingir o maior número de leitores.

61 No final do século 19, a popularização do jornal entre as camadas sociais mais baixas ficou marcada pela imprensa marrom sensacionalista da disputa entre o New York World e o New York Journal. 
de informação através de ferramentas visuais iniciou-se na Antiguidade, como propõe De Pablos, mas seu uso em jornais dependeu da evolução da imprensa, do desenvolvimento da cartografia, do pensamento estatístico e da ilustração científica, do surgimento de tecnologias de transmissão e impressão e das mudanças da linguagem jornalística (que, por sua vez, se relacionam com as mudanças da vida social).

Essa história é abordada como diagrama: uma linha do tempo. O objetivo das informações levantadas não é compor um almanaque de curiosidades, mas evidenciar tanto a evolução da comunicação gráfica ao longo dos séculos como as relações entre cada face desse processo.

\subsection{Conceituação}

A defesa de que a história da infografia se iniciou nos registros da Antiguidade evidencia a noção de infográfico adotada por De Pablos (1999, p. 19) e difundida popularmente: "a infografia é a apresentação impressa de um binômio imagem + texto $(\mathrm{bI}+\mathrm{T})$, qualquer que seja o suporte onde se apresenta essa união informativa: tela, papel, plástico, barro, pergaminho, papiro, pedra”. A listagem de suportes também denuncia que a infografia, para o autor, era uma técnica que permeou a história da comunicação humana.

Como foi explicado anteriormente, o par texto + imagem não é um critério adequado para determinar uma infografia. O uso desse conjunto é realmente encontrado em registros da Antiguidade, mas em situações de subordinação. A diferença de um infográfico está no modo de leitura, na forma na qual nossos processos cognitivos reorganizam a mensagem. Como defende Holmes (Heller, 2006, p. 37, tradução nossa), gráficos podem ser apenas "grupos de palavras arrumadas de forma que podem ser lidas de uma maneira lógica - apenas não como uma sequência de frases".

Cairo (2008, p. 21-22, tradução nossa) constrói sua definição de infográficos em dois passos: (1) “Um infográfico (ou infografia) é uma representação diagramática de dados” e (2) "Um diagrama é uma representação abstrata de uma realidade".

A abstração é, para Cairo (2008, p. 22, tradução nossa), "um componente essencial no design de diagramas” porque faz o papel da seleção de informações: as características irrelevantes são eliminadas ou reduzidas para que a informação importante ganhe destaque. $\mathrm{O}$ grau de abstração depende de fatores como a familiaridade que o leitor tem com o que está sendo representado e seu conhecimento sobre os códigos de representação.

Isso indica que o leitor completa mentalmente as abstrações feitas no diagrama.

Para reconhecer um rosto não é necessário ver cada pequeno detalhe da pele, cada poro e cada ruga; é suficiente identificar aquelas 'características acidentais' do objeto (traços que o definem como pertencente a uma categoria concreta, como formas que se pareçam a olhos, nariz e boca), para que automaticamente o cérebro faça uma inferência baseada em regras inatas e em conhecimentos previamente adquiridos e memorizados. (Cairo, 2008, p. 23, tradução nossa) 

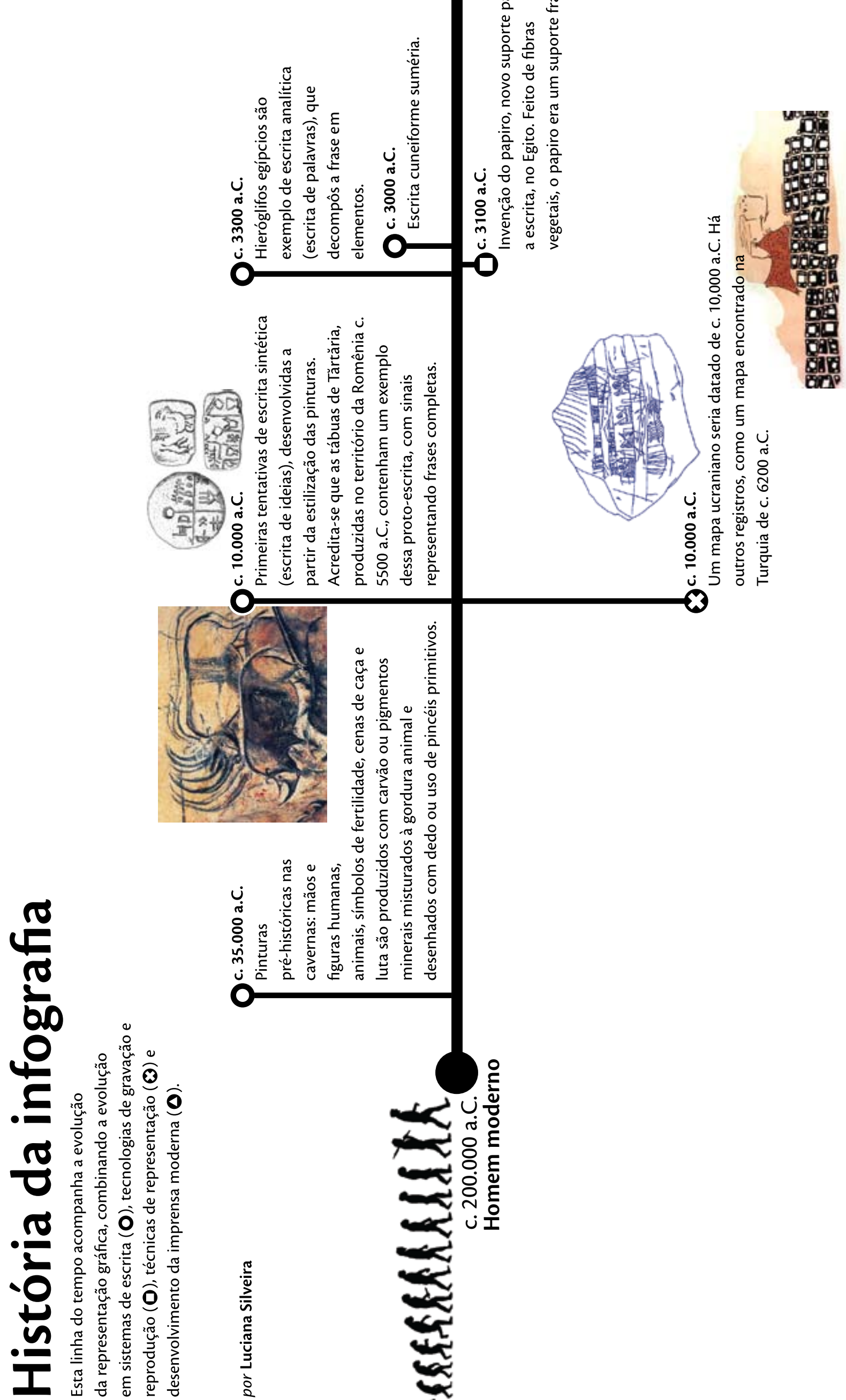

ฐ

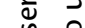

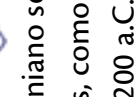

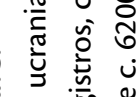

告

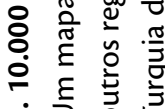

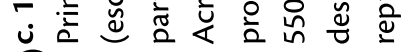
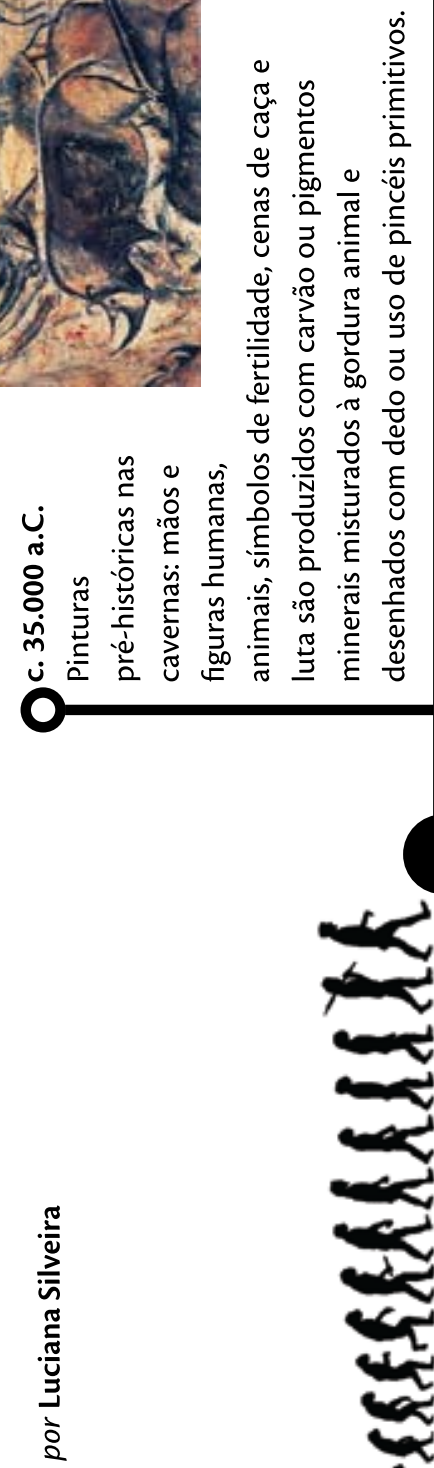


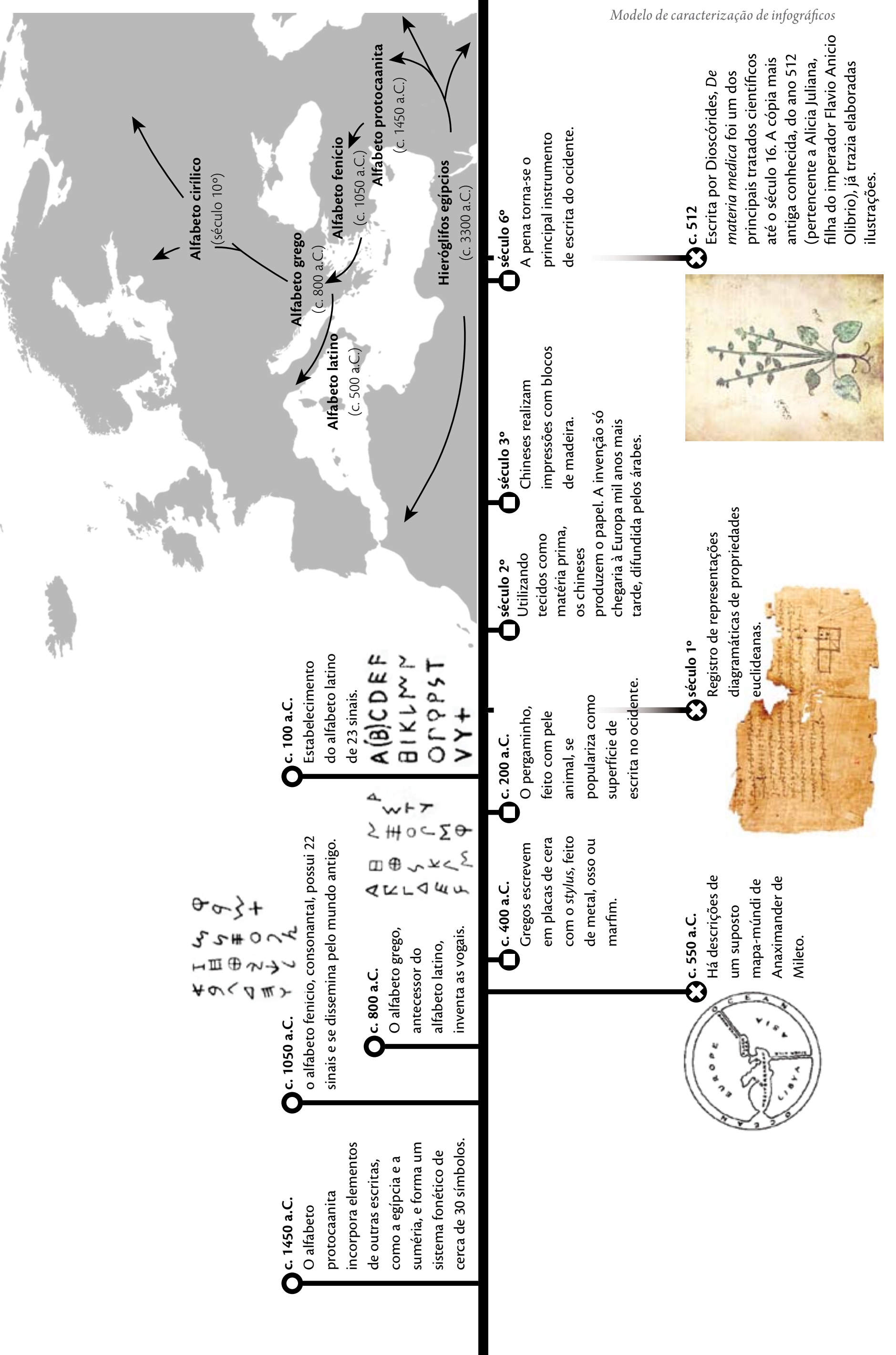



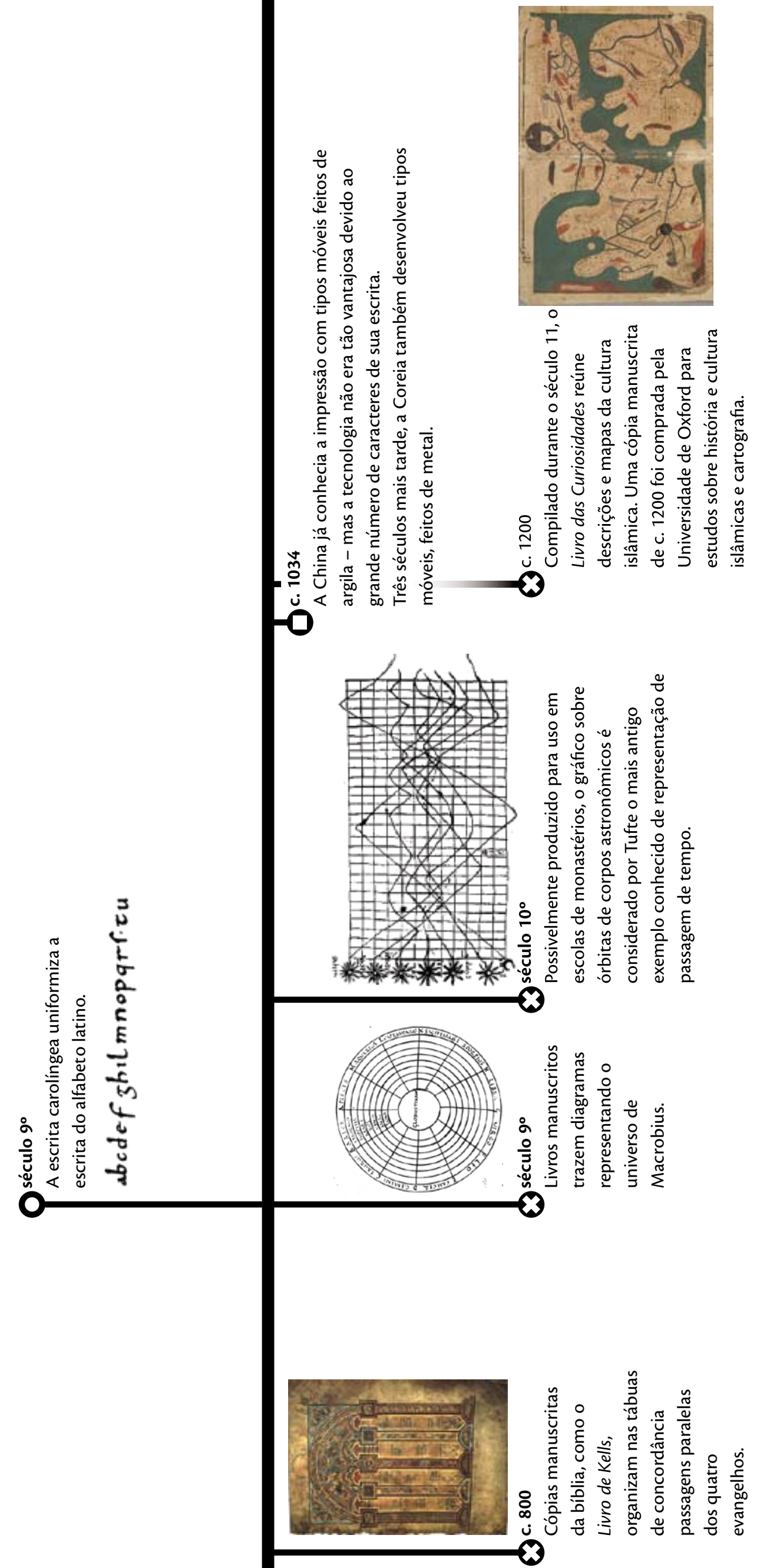

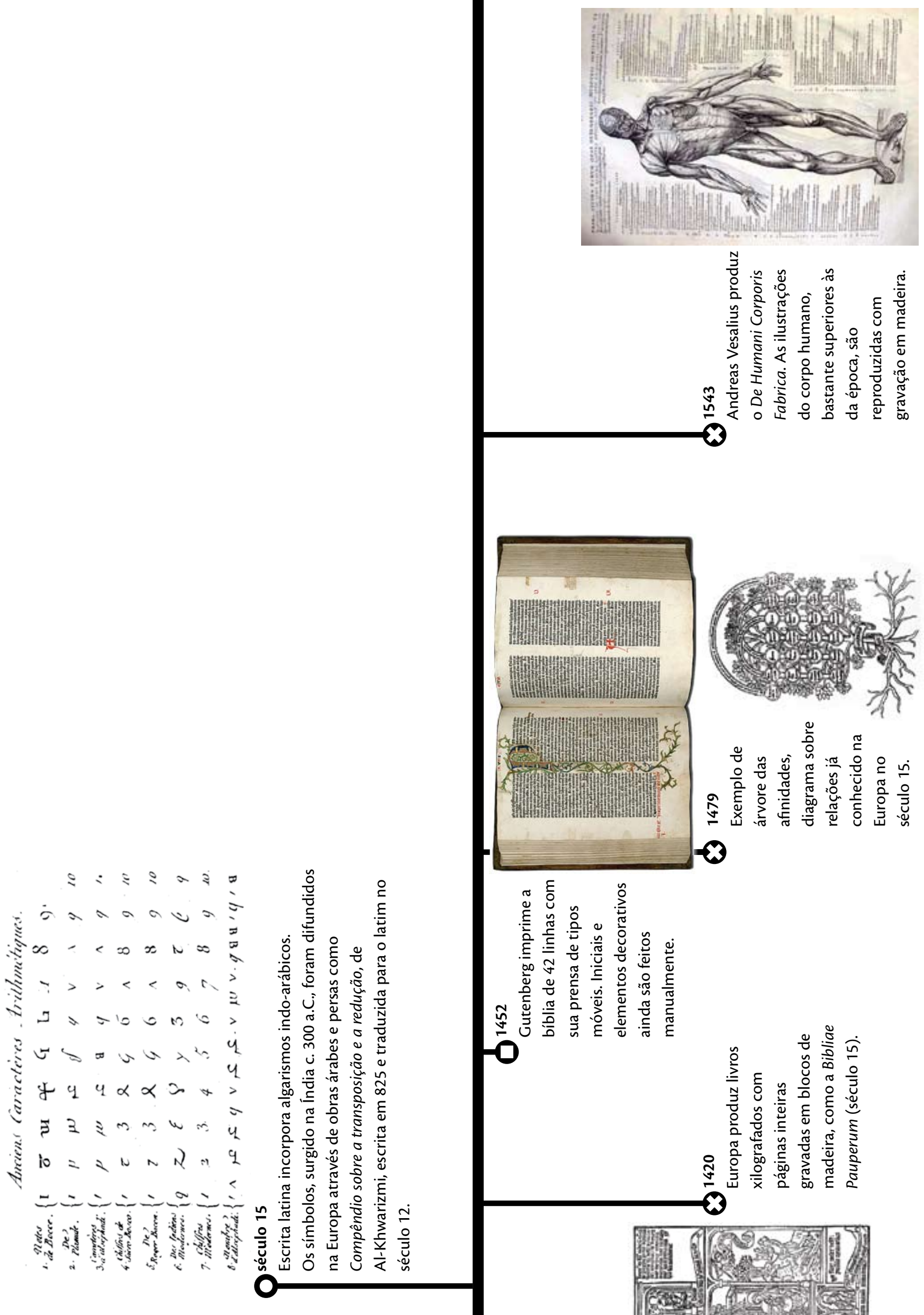

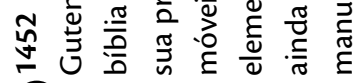

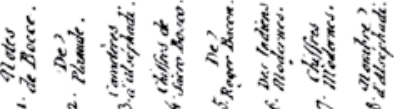



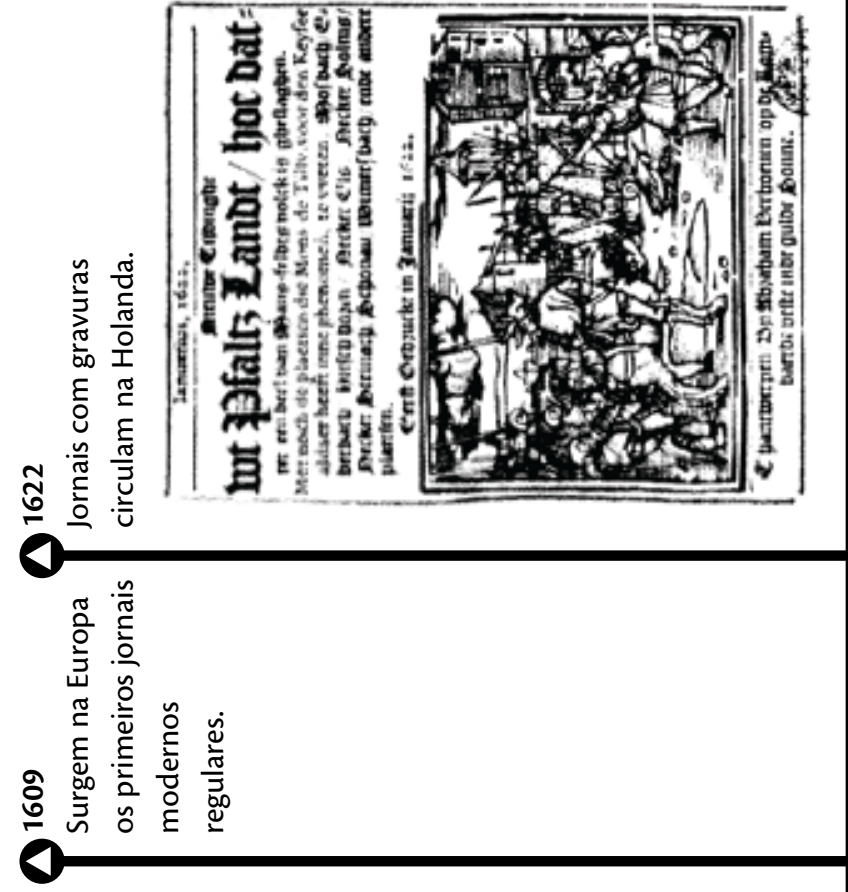

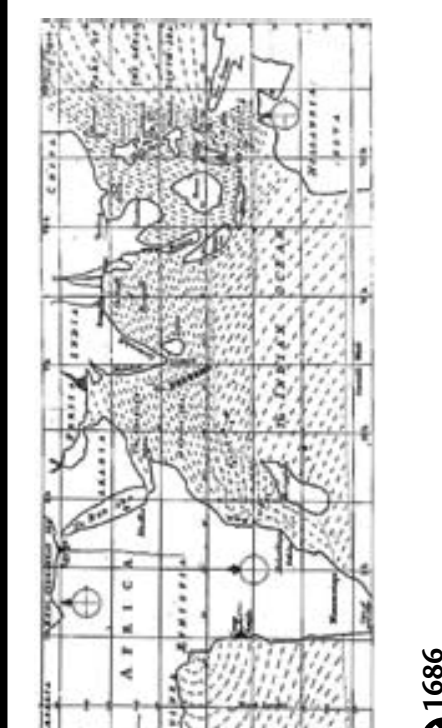

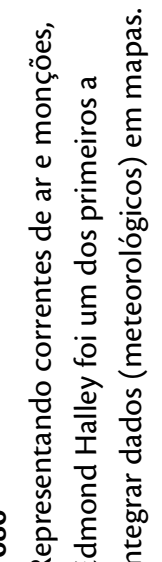

$\theta$

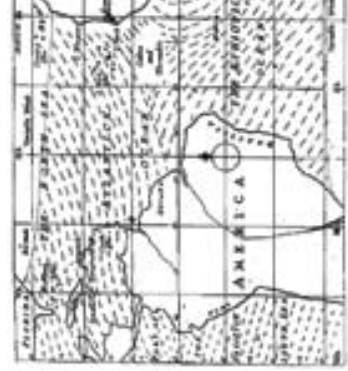

융

융

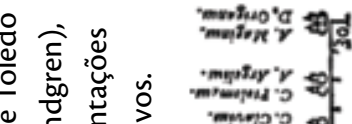

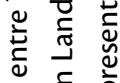

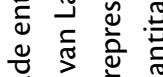

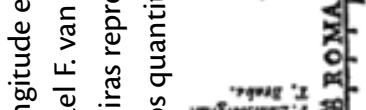

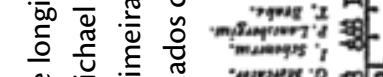

음 藏

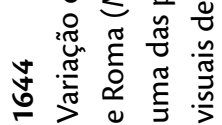

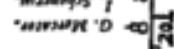

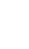

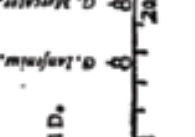

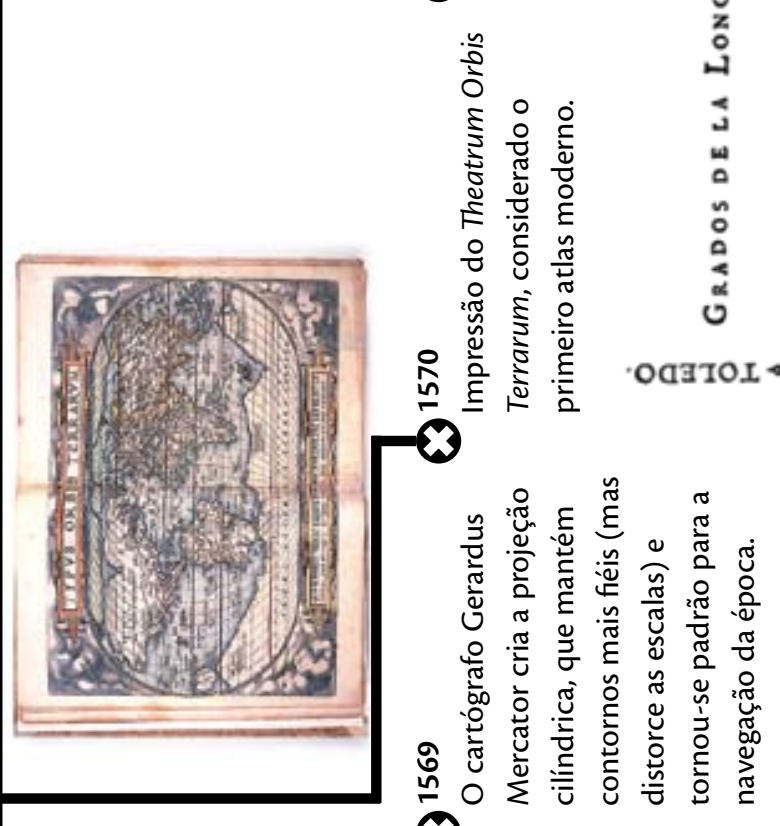

0

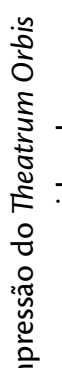

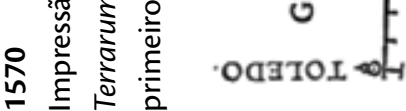

B

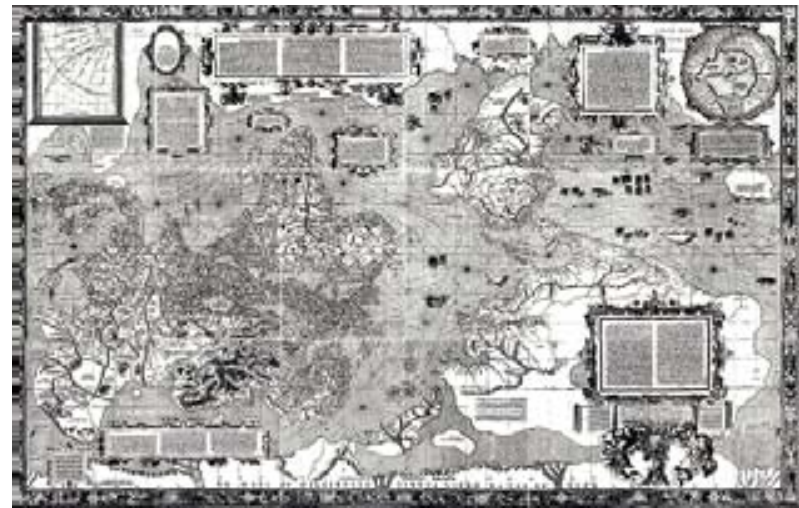



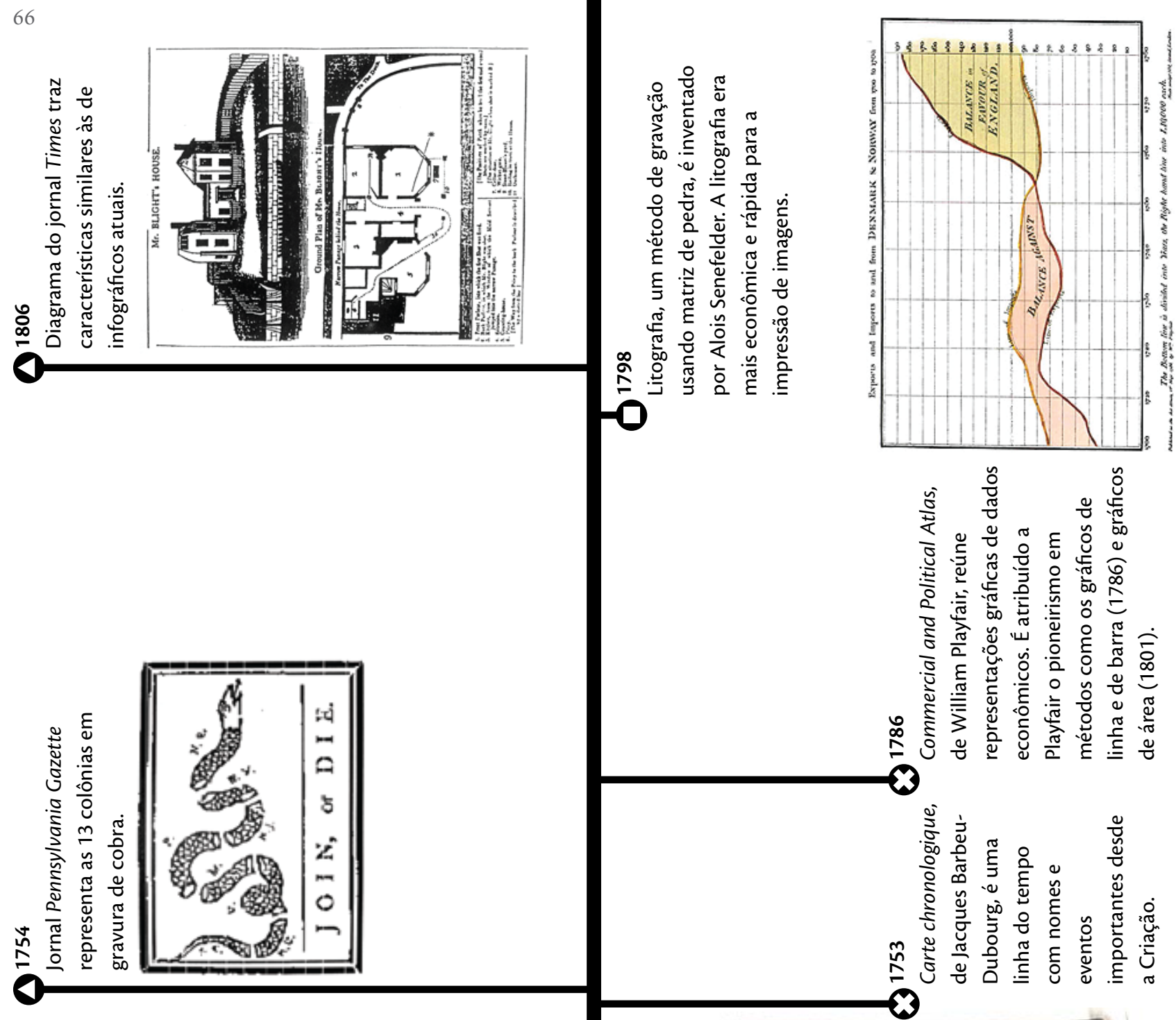

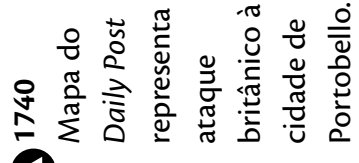
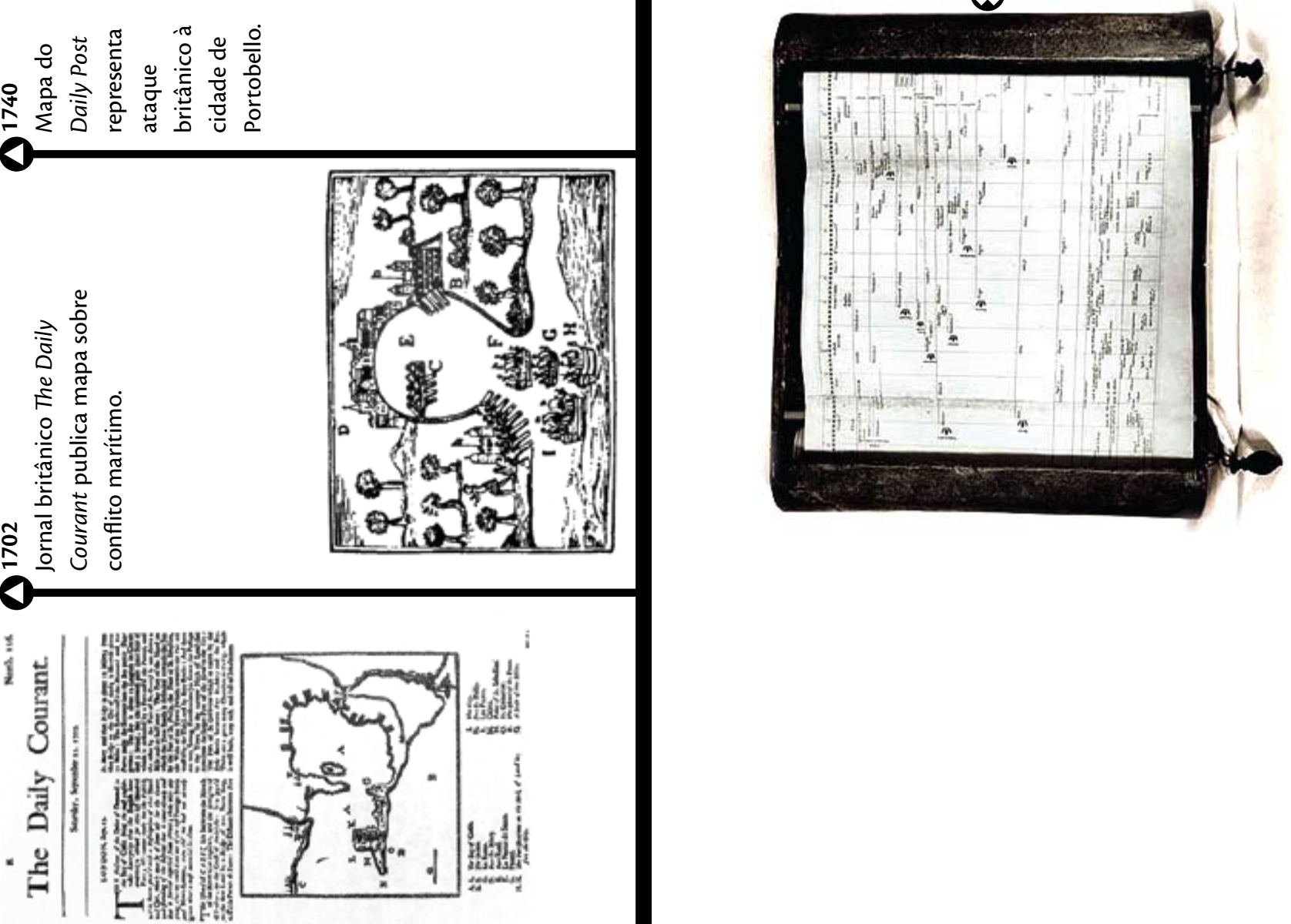


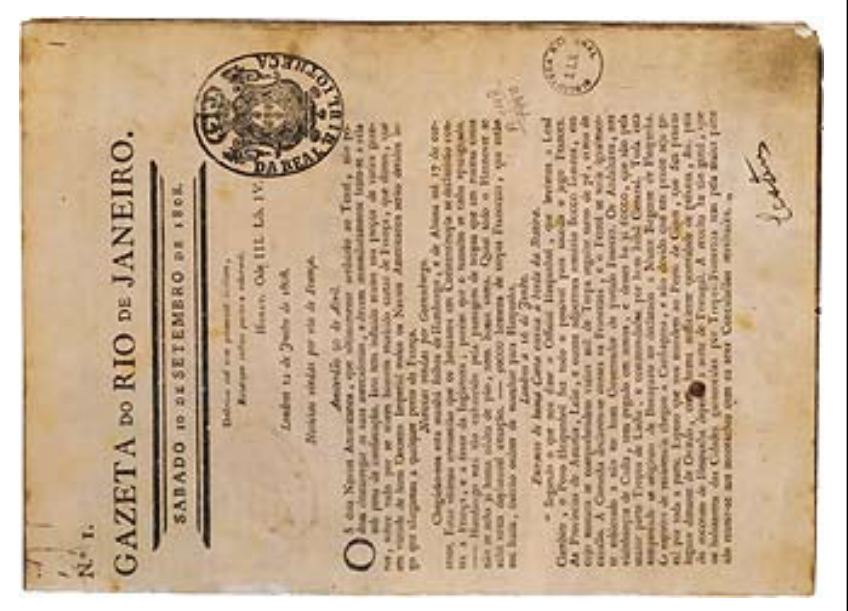

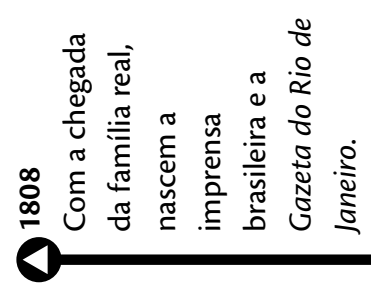

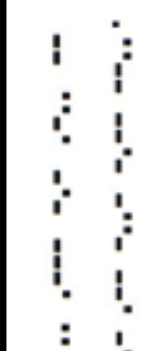

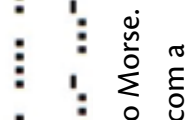

; : 1 :

$\therefore \quad \vdots \quad: 0$

$:: \tilde{y}^{\circ}$

: i. :

$\therefore$ i.

$\because \quad$ i

i.

:

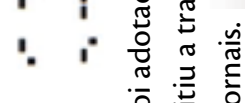

훈

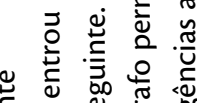

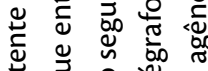

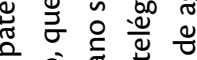

完

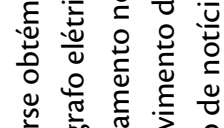

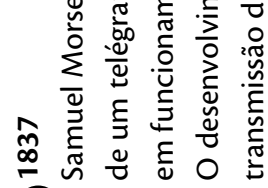

10

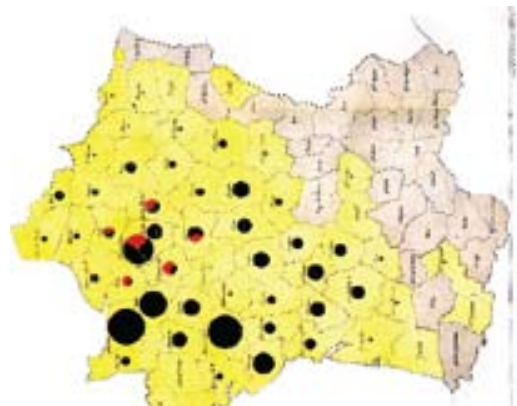

T

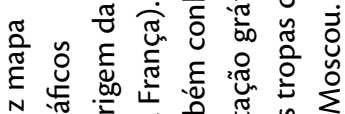

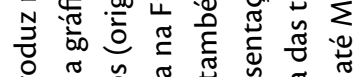

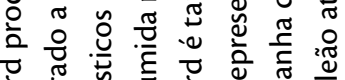

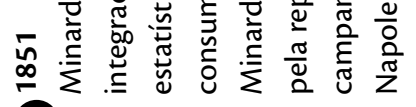

3

产䓂

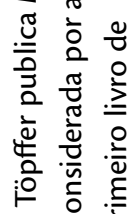

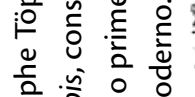

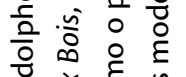

足

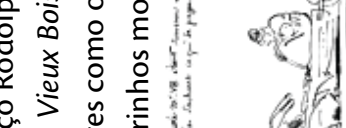

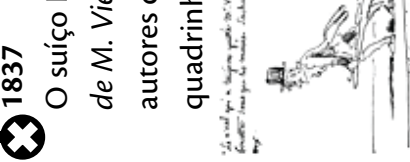

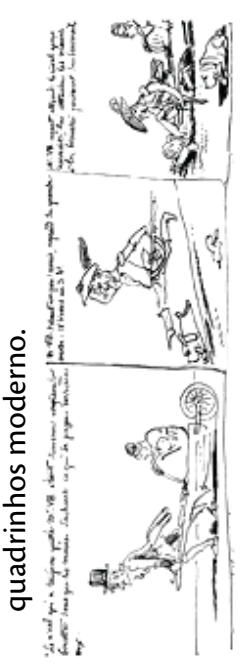

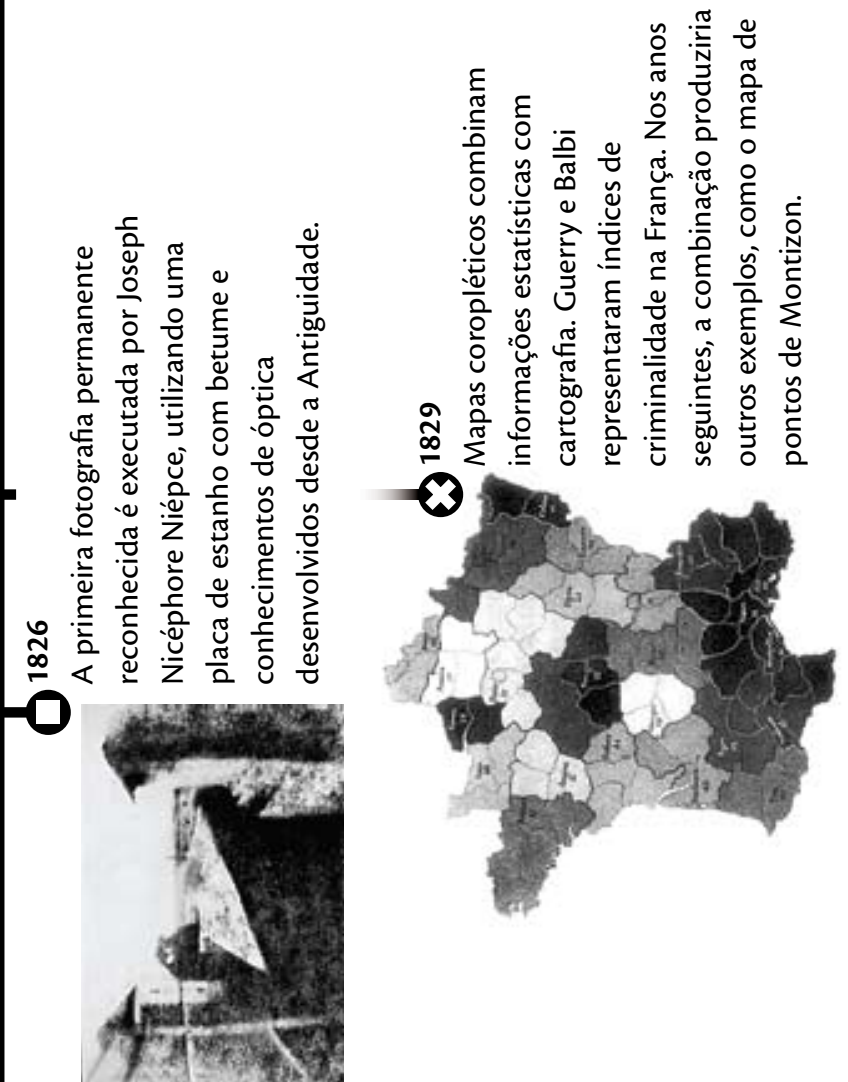




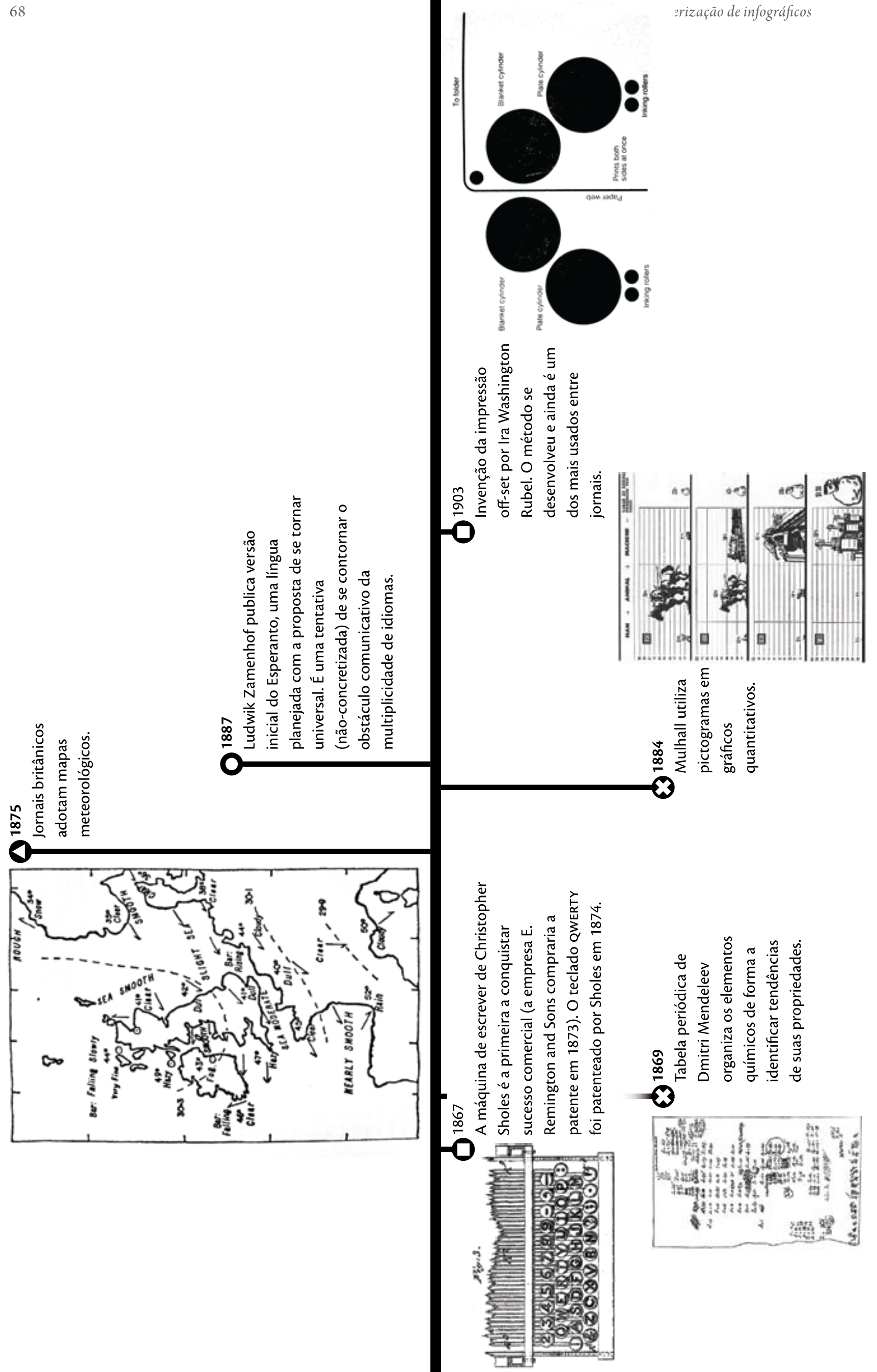



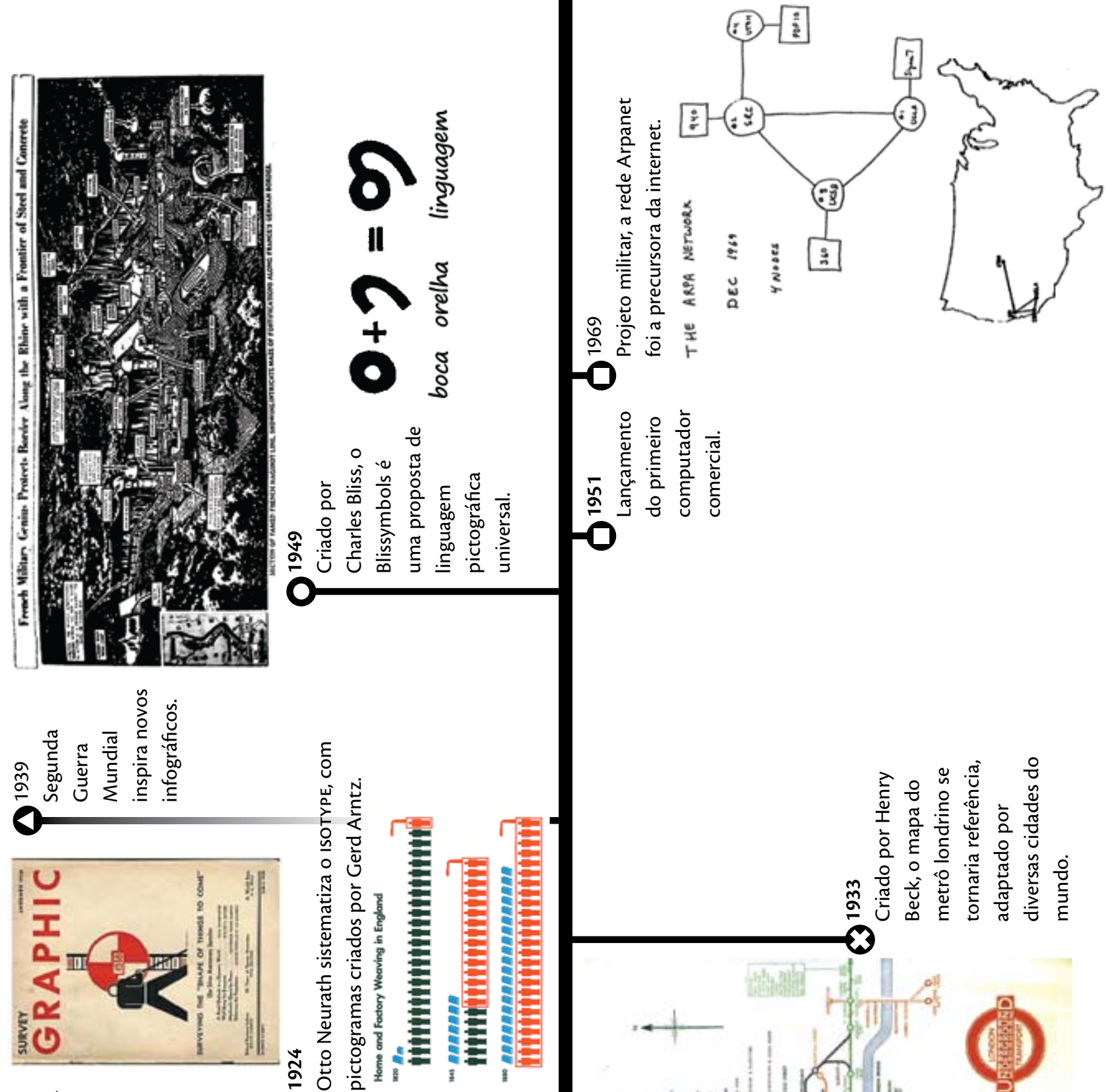

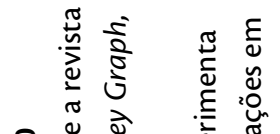

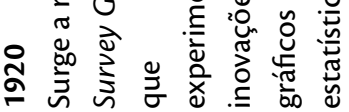
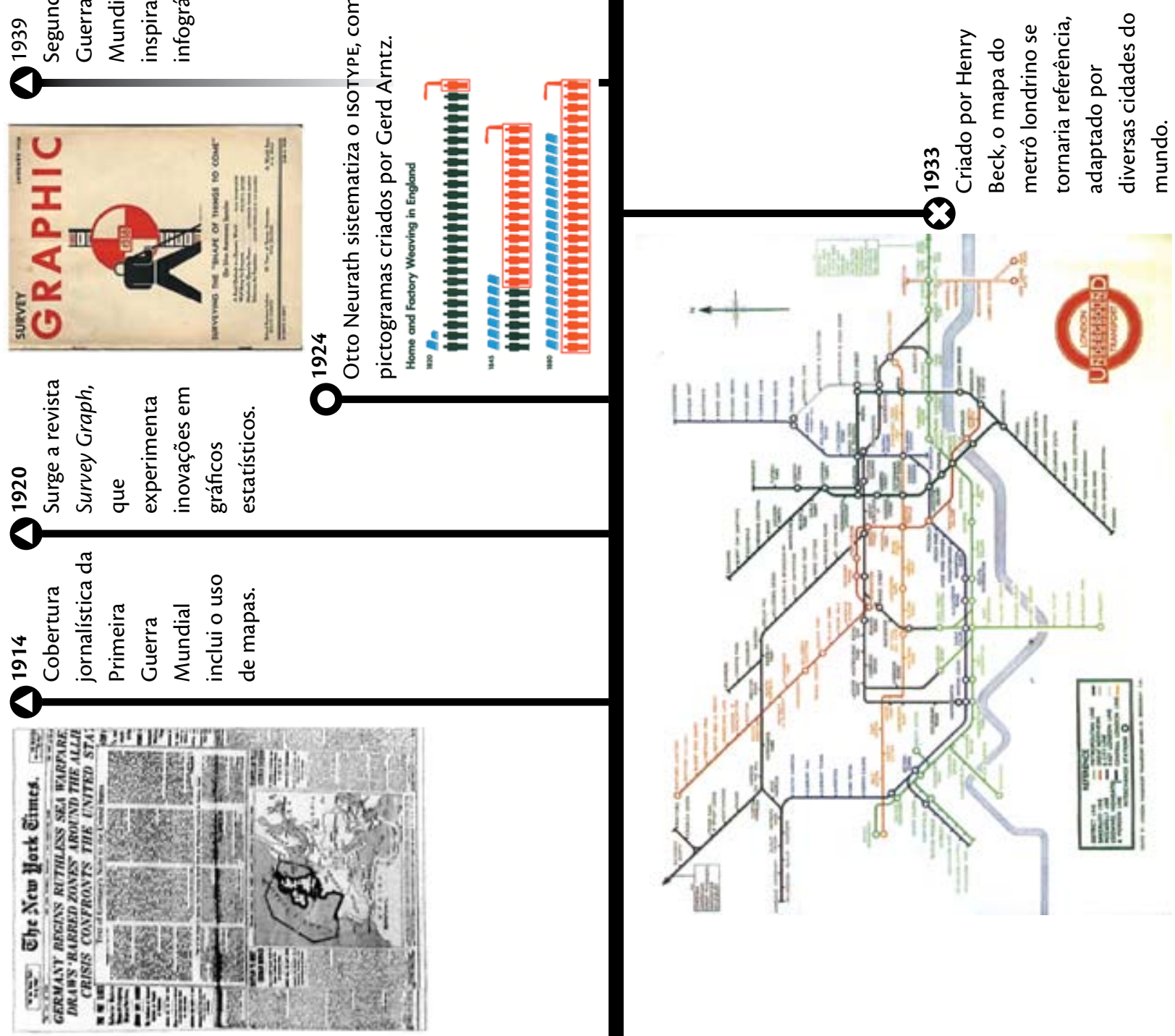

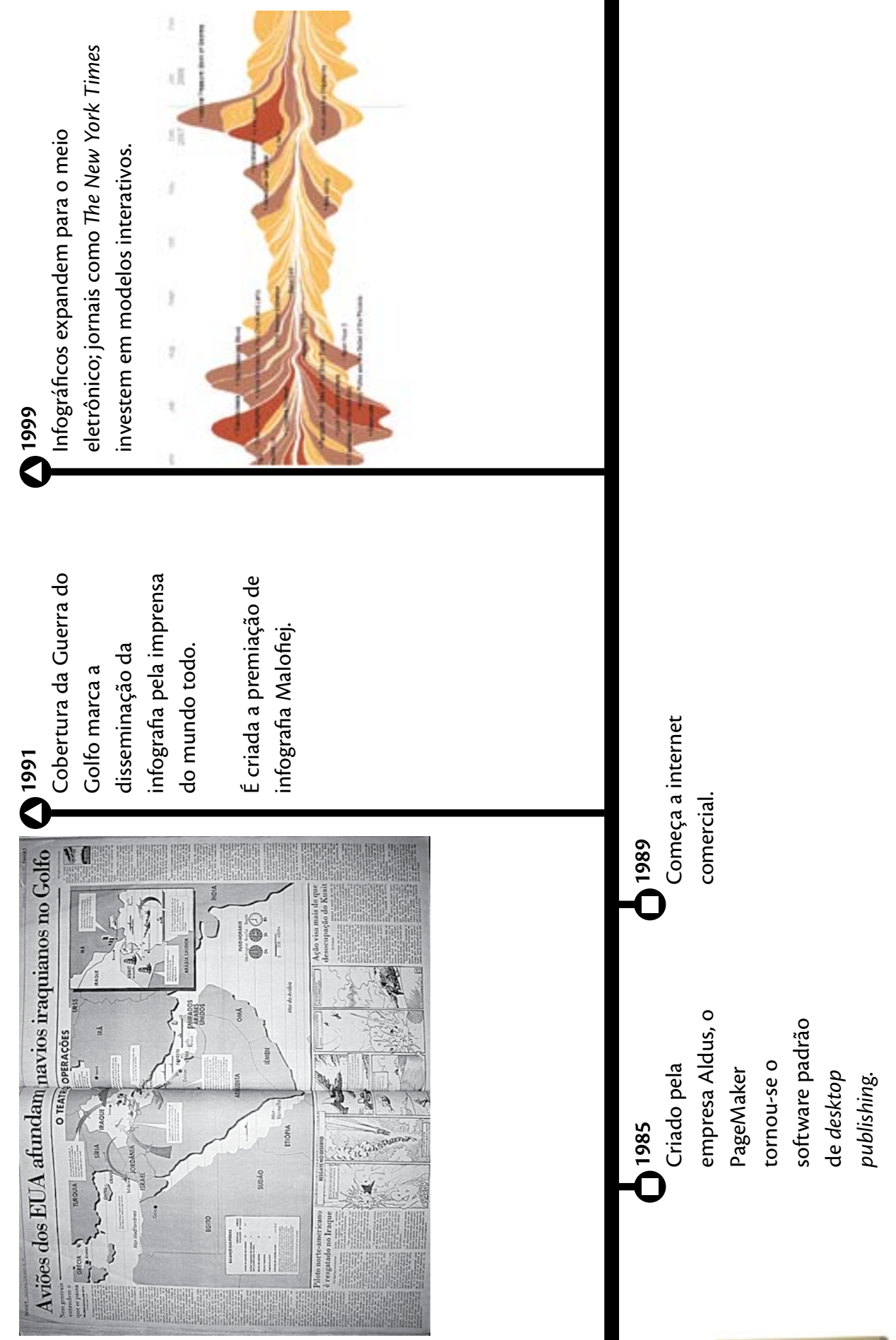

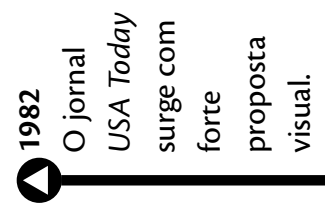

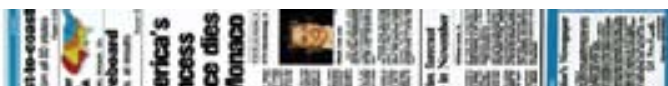

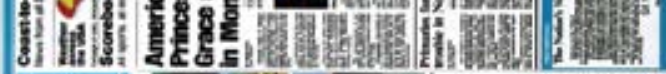
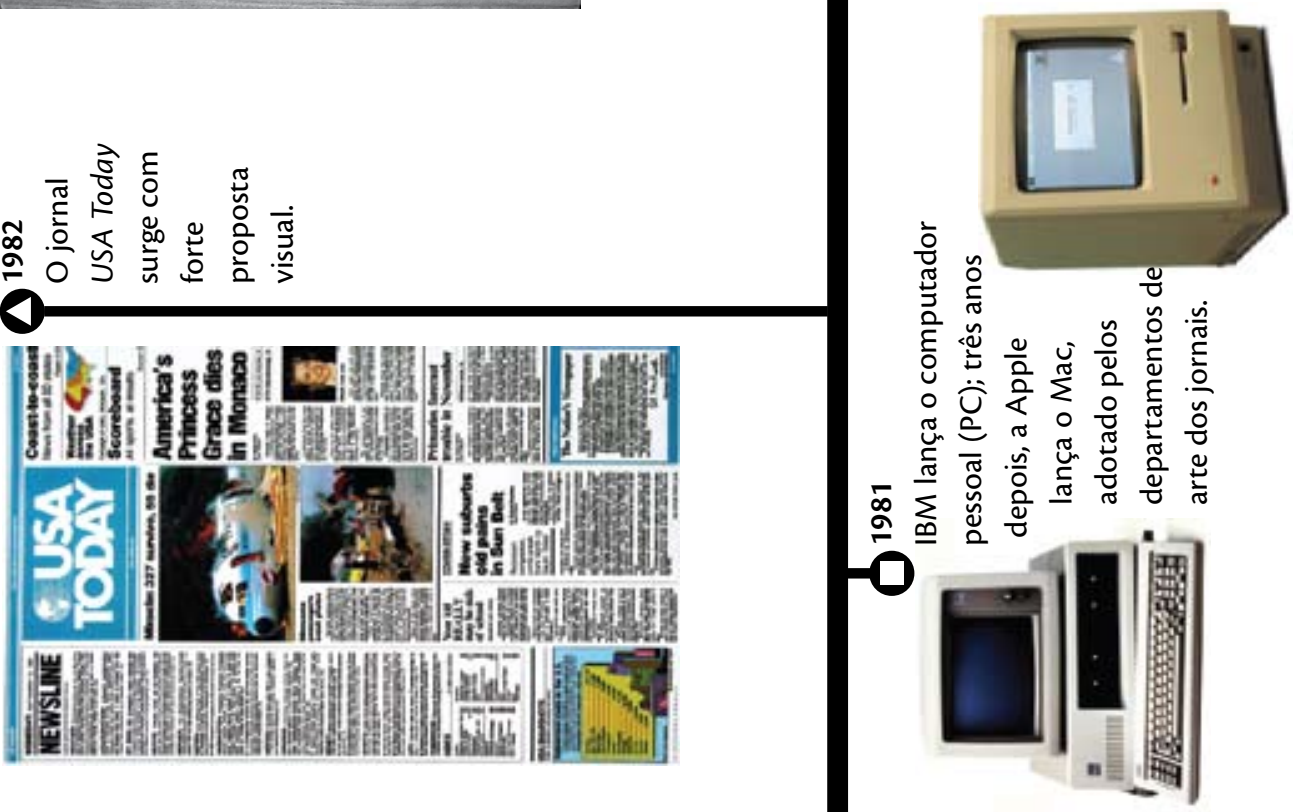
Ware (2008, p. 131, tradução nossa) reconhece nos diagramas uma posição intermediária "combinando significados de símbolos arbitrários aceitos e significados de padrões usados para mostrar relações”. Componentes abstratos como linhas e elementos espaciais são usados para "conectar conceitos mais básicos", estruturando ideias. Um mapa é, portanto, um retrato abstrato de uma área geográfica, enquanto uma ilustração é a representação abstrata de um objeto. Nessa lógica, podemos inferir que uma tabela é a representação igualmente

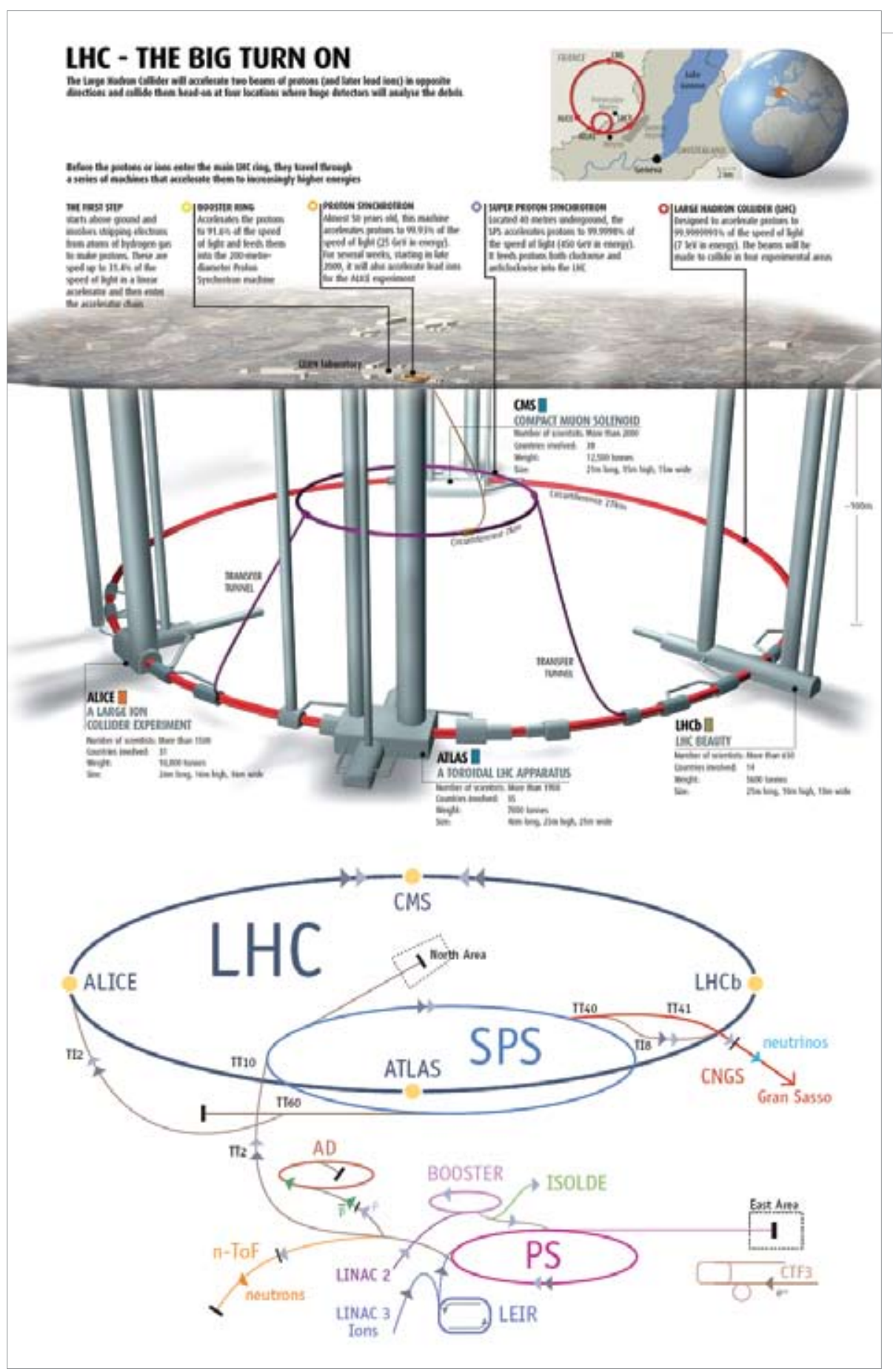

\section{Público e graus de} abstração

Infográfico da revista

New Scientist

(set./2008), voltada

a público não-

especializado, é menos

abstrato que o diagrama

divulgado pelo CERN. 


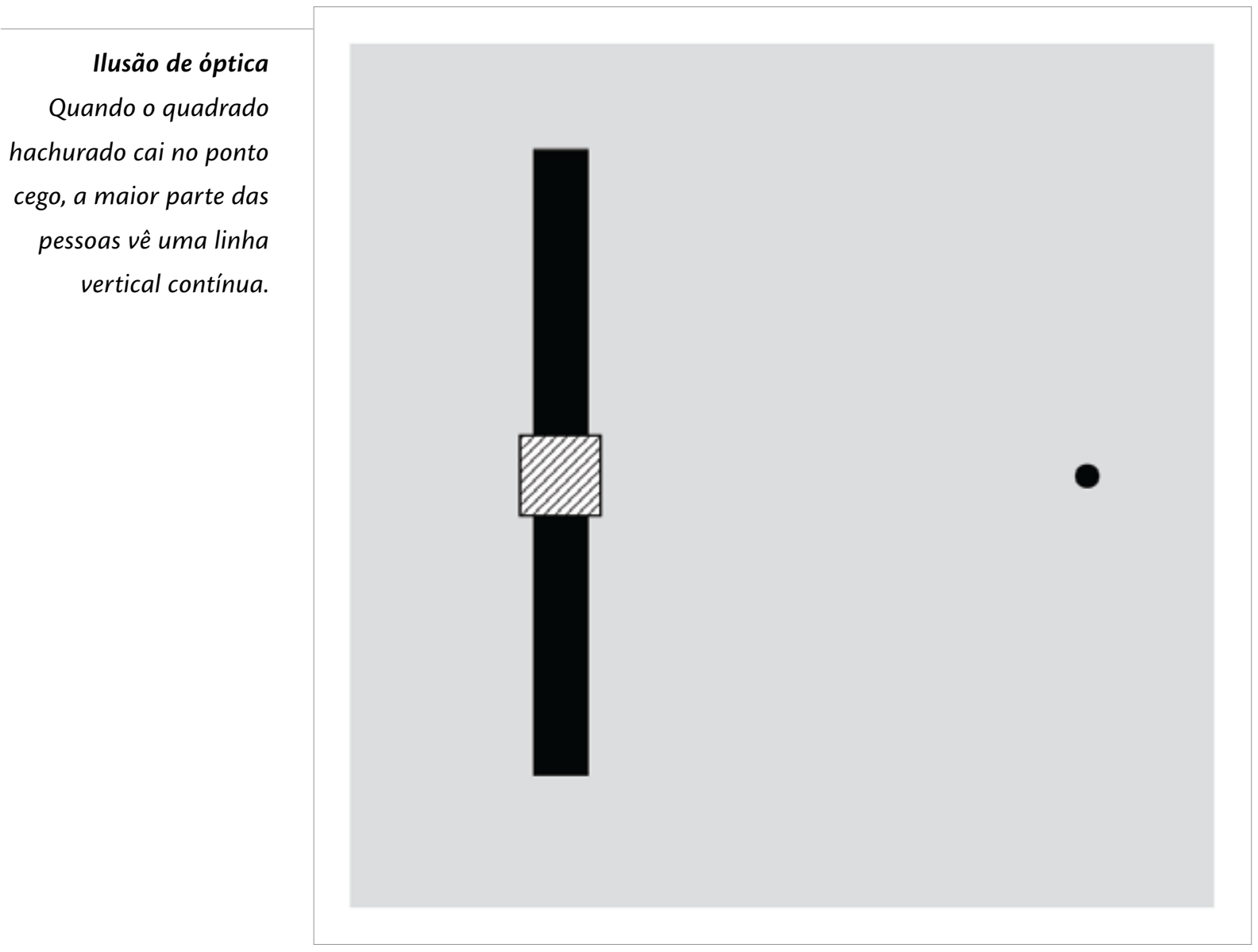

\section{Abstração e preenchimento}

VISUAL

Com o olho direito fechado, observe o ponto escuro à direita da imagem.

Movimente a página para frente ou para trás. Quando o retângulo hachurado entrar em seu ponto cego, perceba o que acontece com a linha preta vertical: ela parece contínua.

\section{Esse fenômeno é explicado por} Ramachandran (2002, p. 125): "A mente, como a natureza, tem horror ao vácuo e aparentemente vai fornecer qualquer tipo de informação que seja necessária para completar a cena”. No caso do ponto cego, que é o espaço da retina que não possui células sensoriais, a mente completa a cena observada de acordo com as informações do que está ao redor - neste exemplo, uma linha preta vertical.

A capacidade de preenchimento não se restringe ao ponto cego. Brincar com essa ilusão apenas nos ajuda a compreender as formas como nosso cérebro completa aquilo que vemos - usando nossa memória e nosso conhecimento prévio.

Ramachandran cita outros dois exemplos bastante conhecidos. $\mathrm{O}$ primeiro é o coelho atrás de uma cerca, que é percebido como um coelho inteiro ainda que nossos olhos vejam um coelho “fatiado". O outro exemplo é o rabo de um gato saindo de trás de um sofá - sabemos 
instintivamente que existe um gato

completo escondido, e podemos imaginar

esse gato.

No exemplo de Cairo (2008, p.

23), podemos identificar um rosto em um desenho porque encontramos nele

algumas características - os olhos, a

boca - e automaticamente relacionamos a representação ao objeto.
Da mesma forma, uma representação

simplificada de um elefante precisa de pouco mais do que uma tromba para que o diferenciemos de outro grande animal, como um hipopótamo. Em um mapa de ruas, não precisamos de desenhos de casas para reconhecer quais formas representam as vias e quais formas representam as quadras.

abstrata das relações formadas entre os $\operatorname{dados}^{62}$. A estrutura de linhas e colunas é suficiente para que façamos as comparações dos dados de acordo com o rótulo oferecido.

Mas somente as características formais não são suficientes para determinar um infográfico. Essa linguagem também se diferencia dos demais elementos do jornal por conta de sua função.

De Pablos (1999, p. 30, tradução nossa) vê uma função dupla na infografia: "facilitar a comunicação de certo tipo de informações e prestar apoio ao diário clássico em período de recessão de leitura e perda de leitores para outros meios" ${ }^{\prime 3}$. A ideia da infografia como "facilitadora da informação" ecoa na visão de que a leitura de um infográfico deve ser fácil e rápida ${ }^{64}$, além de tornar o jornal "mais atraente". A suposta rapidez na leitura de infográficos também está presente em Peltzer (1992, p. 13): "a tendência é precisamente gráfica, mais visual que literal; entender as coisas fácil e rapidamente, num relance, por mais complexas que elas sejam".

Mas o infográfico, como comunicação visual ${ }^{65}$, não repete os mesmos processos cognitivos que uma pintura. Mesmo que o fizesse, o olhar de relance para uma imagem não encerra seu conteúdo - é preciso também observar os detalhes. Nos detalhes, encontram-se elementos verbais, representações quantitativas, possibilidades comparativas e diversos tipos de dados que geram análises e conclusões - não é, necessariamente, um procedimento "rápido"; tampouco existe a obrigatoriedade de que seja "fácil".

A infografia é um processo de visualização da informação, uma "ferramenta de amplificação da cognição e da memória” (Cairo, 2008, p. 34, tradução nossa). A função do infográfico

62 Toda a diagramação de um jornal - a diferença tipográfica entre título e texto, por exemplo - não será considerada infografia devido à função exercida. Enquanto a diagramação indica uma ordem de hierarquia e de leitura, o infográfico propõe narrativas, explicações e análises.

63 Quanto à segunda função proposta por De Pablos consultar o capítulo sobre Jornalismo.

64 Cairo (2008, p. 30) questiona esse tipo de visão sobre a infografia, relacionando-a também ao menosprezo sobre o visual como ferramenta comunicativa.

65 Para Costa (1998), comunicação visual é uma “terceira linguagem” - diferenciando-se da primeira linguagem, a imagem, e da segunda linguagem, o signo. 
é tornar algo visível ao leitor - esse algo pode ser um "como", pode ser uma comparação de valores, pode ser uma situação de causa-e-consequência, entre outras possibilidades.

Por compartilhar de propriedades da imagem, o infográfico pode abranger a informação de forma mais completa. Por compartilhar de propriedades da escrita, o infográfico reduz a polissemia relacionada às imagens. Meyer (1997, p. 68) reforça que elementos visuais dão sentido à precisão dos elementos textuais, e que o uso conjunto tem resultado mais memorável.

Mas a função da infografia não pode ser desvinculada dos princípios do jornalismo. Embora De Pablos (1999, p. 19) seja liberal quanto ao suporte do infográfico e Cairo (2008, p. 21, tradução nossa) argumente que "uma infografia não tem por que ser publicada por um 'periódico' para ser considerada como tal”, esta pesquisa considera que o termo "infográfico" e, portanto, sua análise se restrinjam ao jornalismo.

Essa visão se ampara em Horn (2000, p. 17, tradução nossa), que cita o uso de terminologias diferenciadas para as aplicações do design da informação em cada tipo de atividade. "Em jornais e revistas, são chamados information graphics; nos negócios, se chamam presentation graphics ou business graphics; e na ciência, são conhecidos como visualização científica".

Dessa forma, o infográfico também se submete à lógica da linguagem jornalística. Um exemplo de diferença entre um infográfico e uma visualização científica está no fato de que a argumentação científica tem espaço para a apresentação de "conclusões". No jornalismo, por outro lado, evita-se uma "moral da história” explícita, e as conclusões devem ser encontradas pelo leitor. Assim, um infográfico precisa tornar mais claras as relações entre os dados.

Outra diferença está no tipo de público. Uma comunicação científica geralmente se dirige à comunidade de pares do pesquisador, que possuem grau de conhecimento sobre o assunto abordado. No jornalismo, por outro lado, é comum que o público leitor seja mais amplo e heterogêneo, e o grau de conhecimento prévio sobre o assunto é bastante variado.

\subsection{ClassificaÇões de infográficos}

Não há consenso na classificação de infográficos. Peltzer (1992, p. 125) divide os elementos imagéticos da linguagem jornalística entre tipos como gráficos, infográficos, mapas, símbolos e comic informativo. Já De Pablos (1999, p. 125) considera que o conjunto de infográficos inclui "febre e barras, pizza ou torta, tabela numérica, sumário infográfico, diagrama jornalístico”. Para Cairo (2008, p. 94), essa divisão não é adotada - mapa, gráfico estatístico, diagrama explicativo são ferramentas, recursos usados no infográfico.

Interessante também é a proposta de $\operatorname{Roam}^{66}$ (2008, p. 129), que classifica estruturas de apresentação de acordo com a forma como as informações são processadas ${ }^{67}$. Considerando

$66 \mathrm{O}$ trabalho do autor tem enfoque na área de presentation graphics, mais administrativa.

67 A definição das “formas de ver” está relacionada aos estudos sobre as vias do sistema de percepção visual, confor- 
a apresentação como o final do processo de visualização, o autor determina uma regra: "para cada um dos seis modos de ver, existe um modo de mostrar correspondente. Para cada um dos seis modos de mostrar, existe um único quadro visual que serve como ponto de partida" (Roam, 2008, p. 133, tradução nossa).

O modelo de Roam chama a atenção porque se relaciona com os elementos do lead jornalístico, que compõem também a forma tradicional de uma narrativa. O importante não é mais a forma, mas sim o conteúdo - quais perguntas são respondidas por um gráfico.

Além disso, o modelo compreende todos os tipos de gráficos tradicionalmente listados - sejam eles mapas, gráficos de barras ou tantos outros. Dos seis modos de apresentar a informação também nascem combinações - por exemplo, um gráfico de linha exibe as variações quantitativas ao longo do tempo.

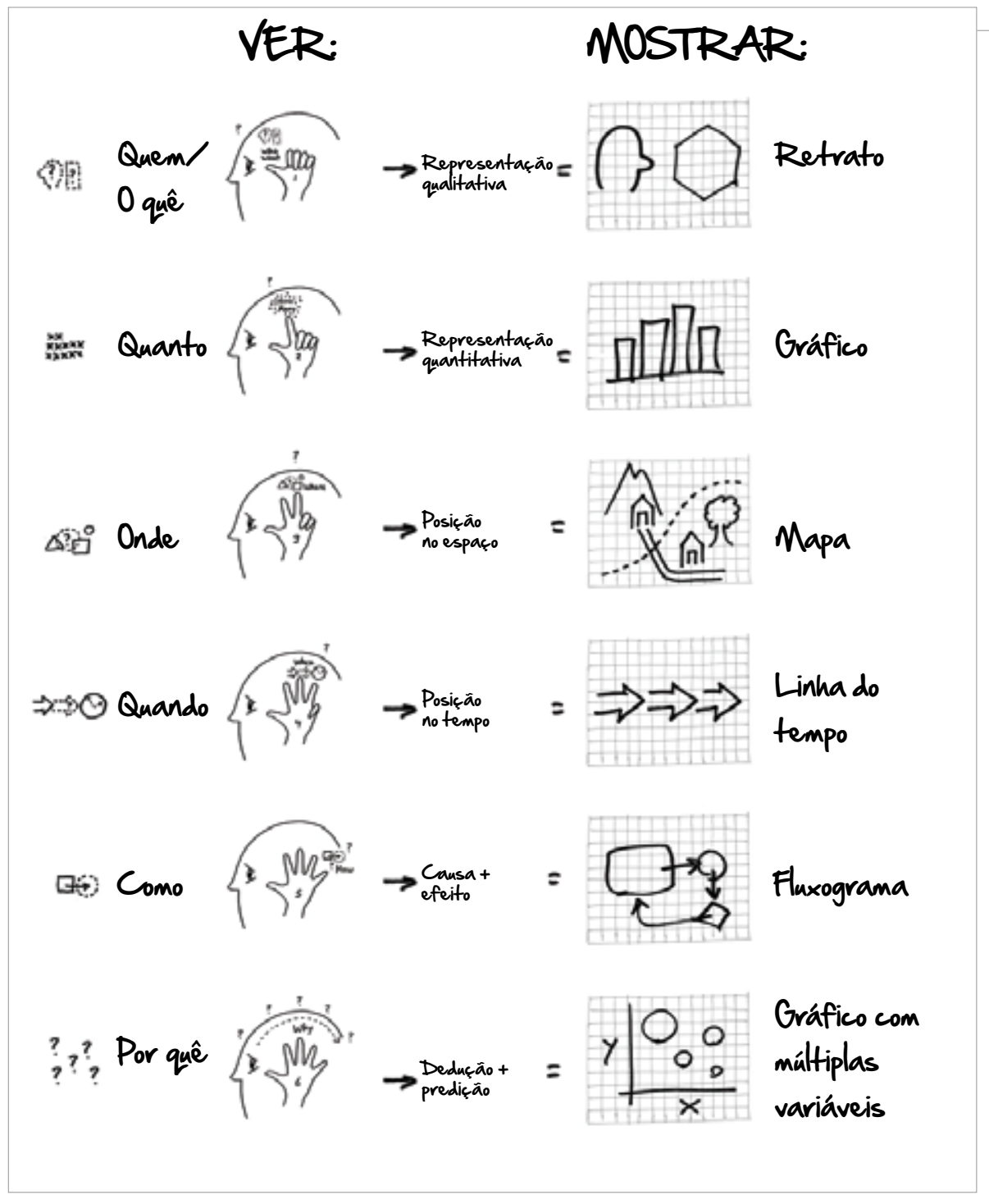

A regra $<6><6>$

Roam relaciona tipos de diagramas a modos de ver. 


\subsubsection{Reportagem infográfica: independente e específica}

Teixeira $^{68}$ (2007, p. 115) propõe a classificação de infográficos de acordo com sua relação com a notícia e com a página. A primeira divisão está no tipo de informação representada: enciclopédica (de caráter mais universal) ou específica (própria do fato noticiado). Cada um desses tipos pode ser dividido entre infográficos independentes (não acompanham outros elementos) e complementares (utilizam formas alternativas de narrativa para contemplar aspectos singulares do acontecimento).

\subsubsection{Estetizantes e analíticos}

A sensação de atualidade produzida pelo diagrama sobre a morte do Sr. Blight, publicado há mais de 200 anos, indica uma evolução bastante limitada da infografia desde então.

\footnotetext{
Nestes dois séculos que separam esta primeira publicação dos dias atuais, muita coisa mudou no fazer jornalístico e, em muitos veículos, não se percebe uma evolução efetiva - não tecnológica, propriamente, mas conceitual - do uso da infografia jornalística, quando comparada àquela primeira representação - apesar de todos os avanços registrados neste período e a massivamente destacada importância das imagens para a comunicação na contemporaneidade (Teixeira, 2007, p. 112).
}

De forma pessimista, o designer Nigel Holmes também avaliou que, "nos últimos anos, a qualidade dos gráficos tem sido medíocre. Infelizmente, novidades ditam moda, e estamos mais preocupados em divertir do que em informar" (Errea, 2004, p. 6, tradução nossa).

Entretanto, Cairo (2008, p. 29, tradução nossa) percebe o presente como uma etapa de transição ${ }^{69}$ entre uma infografia mais "estetizante" (predominante nos meios jornalísticos), que enfatiza o poder visual do gráfico para gerar páginas dinâmicas e atraentes, e outra mais "analítica”, que funciona como um apoio para a compreensão, propondo-se a tornar visível o que está oculto em um "conjunto caótico de dados".

Um dos primeiros exemplos apresentados pelo autor é uma página do jornal The New York Times com um diagrama avaliando as mudanças após as eleições do congresso norteamericano em 2004, que "apresentava os dados de maneira clara, mas, ao mesmo tempo, desafiando a capacidade de atenção" de seus leitores (Cairo, 2008, p. 16, tradução nossa).

68 Embora aceite a estratégia classificação de infográficos apresentada por Teixeira (2007), a pesquisa não segue a mesma conceituação de infográficos da autora, que condiciona o infográfico ao binômio (indissociável) imagem e texto, como De Pablos (1999).

69 Segundo Horn (2000, p. 25, tradução nossa), existe “tensão considerável entre (1) designers gráficos - que aprendem na escola de artes a adorar os deuses do Estilo e da Moda, Novidade, Impacto e Auto-expressão - e (2) pessoal de comunicação técnica - que adoram os deuses da Clareza, Precisão, Legibilidade, Compreensibilidade e (frequentemente) Simplicidade”. 
O infográfico selecionado combina grande quantidade de informações e gera subsídios para a observação e análise de suas relações. Entretanto, devido à complexidade resultante, foi necessária a inclusão de um parágrafo explicando o código adotado ("como ler este gráfico"), contrariando a corrente que prevê nos infográficos uma leitura mais "fácil" e "rápida".

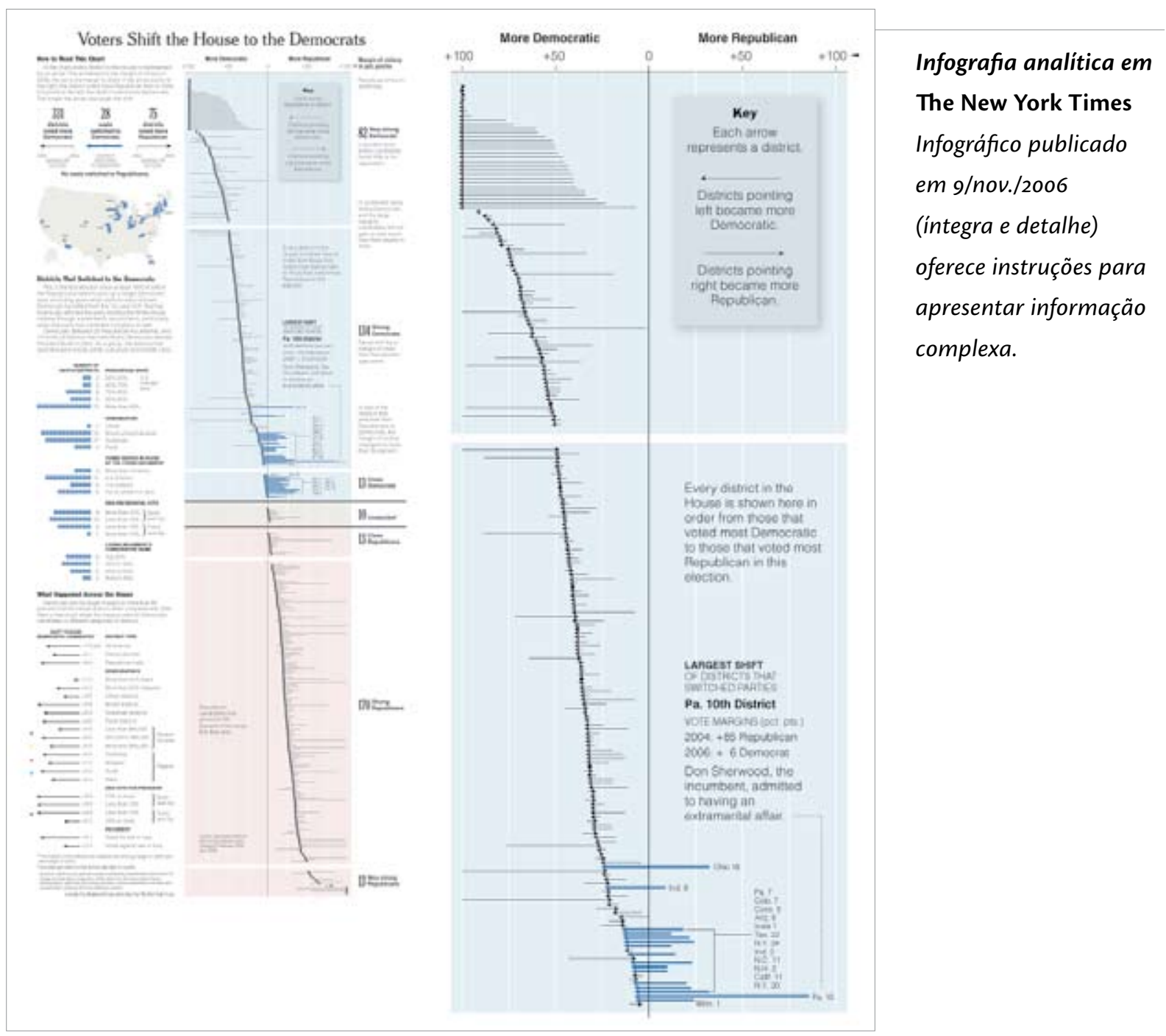

O infográfico estetizante não deixa de ser uma ferramenta informativa e explicativa, mas, em alguns casos os elementos estéticos atrapalham a compreensão (Cairo, 2008, p. 29). Por sua vez, o infográfico analítico também possui uma dimensão estética, mas ela é secundária. Como defende Tufte (2007, p. 80), os dados adequados tornam um gráfico interessante.

Como a apresentação é apenas um estágio do processo de visualização, a mudança da infografia estetizante para a infografia analítica requer também a mudança na forma como o comunicador vê a informação. "Encontrar os números corretos exige uma habilidade especializada - a habilidade estatística - e trabalho duro, da mesma forma que criar um design bonito ou cobrir uma notícia complexa" (Tufte, 2007, p. 80, tradução nossa). 



\section{MODELO DE CARACTERIZAÇÃO DE INFOGRÁFiCOS}

O fazer jornalístico não se restringe ao estilo (objetivo, preciso, claro e conciso), mas também aos procedimentos técnicos e éticos. Kovach e Rosenstiel (2001, p. 114) argumentam que a objetividade jornalística surgiu como "um método consistente de testar a informação", com investigação e verificação.

Um jornalista responsável não se limita ao relato de uma testemunha - é preciso compreender os interesses, buscar pontos de vista, confrontá-los com dados. Assim como a pesquisa científica, o jornalismo tem sua credibilidade nas escolhas metodológicas adequadas.

Entretanto, enquanto uma reportagem não precisa detalhar os passos seguidos em sua realização, a pesquisa científica deve explicitar e explicar os procedimentos adotados para encontrar validade. Na pesquisa sobre jornalismo, a importância crescente da metodologia reflete o amadurecimento do campo. Nas palavras de Marques de Melo (2008, p. 11),

por mais que a criatividade permaneça como requisito indispensável à renovação do trabalho científico, torna-se necessário cultivar hábitos que reproduzam os padrões hegemônicos, reguladores da vida em comunidade.

\subsection{CARACTERIZAÇÃO DE PEÇAS INFOGRÁFICAS}

Popularizado e uniformizado por manuais de redação, o estilo dos textos jornalísticos tem seus elementos estabelecidos e conhecidos - o que facilita sua avaliação. Alguns critérios de forma (preferência pela ordem direta e voz ativa, por exemplo) e conteúdo (impessoal e não opinativo, dando voz aos vários envolvidos) ajudam a orientar sua análise.

No caso dos infográficos, não foram encontrados critérios para o mesmo tipo de avaliação. $\mathrm{O}$ caráter híbrido do infográfico - tanto na forma quanto na interdisciplinaridade - torna inconveniente sua decomposição para análise de cada elemento. No entanto, a partir do levantamento bibliográfico, foram identificados três pares classificativos para infográficos. Cada um desses pares caracteriza o infográfico em sua integridade, observando aspectos ligados a sua função.

- Complementar/independente ${ }^{70}$ (Teixeira, 2007)

- Enciclopédico/específico (Teixeira, 2007)

- Estetizante/analítico (Cairo, 2008)

70 Embora a autora utilize a nomenclatura "complementar" em oposição a "independente", esta pesquisa considera que a complementaridade entre infográficos e demais elementos da reportagem é uma característica intermediária; assim, o par de opostos seria formado por "subordinado" e "independente". 
A leitura de exemplos de infográficos em veículos jornalísticos indicou que esses pares compõem, na verdade, eixos com gradações. Um infográfico pode ter tendência analítica, mas apresentar algumas características estetizante. Por isso, optou-se por uma escala simples atribuindo notas de acordo com a intensidade verificada. $\mathrm{O}$ uso de pontuação numérica facilita a análise e documentação, permitindo representação gráfica e comparações.

\subsubsection{Eixo subordinado-independente}

Os dois primeiros eixos são simples e avaliados com uma escala de o a 3 pontos. Aceitando o modelo tipológico de Teixeira (2007, p. 114), que considera que o formato de reportagem infográfica como um infográfico independente e específico, essas duas qualidades foram posicionadas no extremo de maior pontuação. Esses dois eixos permitem representação gráfica simples, em gráfico do tipo XY.

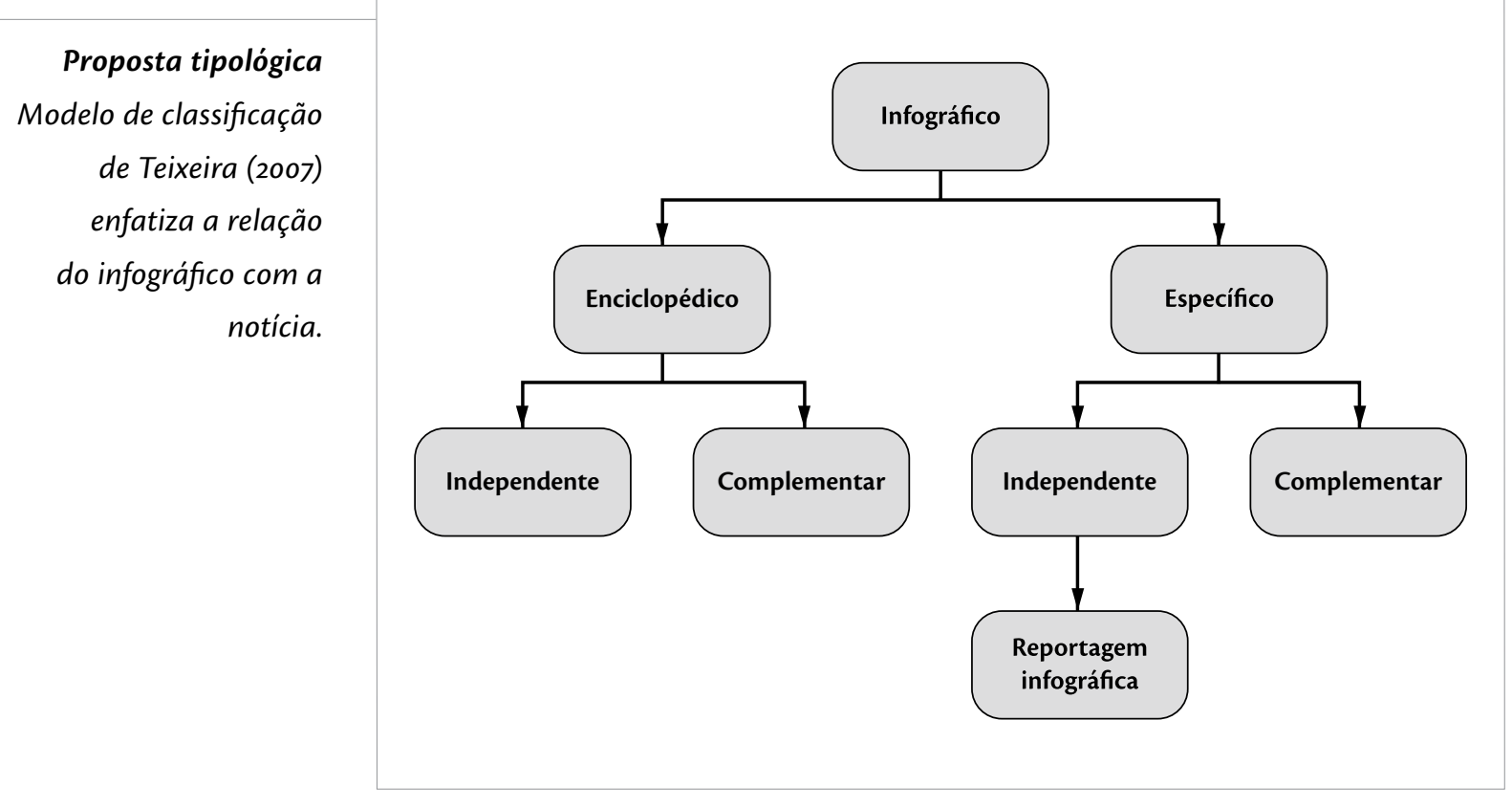

A subordinação do infográfico dentro da reportagem pode ser verificada tanto pelo conteúdo como pelo espaço destinado a ele. Infográficos discretos e com baixo conteúdo informativo são subordinados, pois dependem dos demais elementos da reportagem (como textos verbais e fotografias) para transmitir a mensagem. $\mathrm{O}$ aumento na quantidade e na qualidade da informação contemplada torna o infográfico mais necessário e mais representativo - e esse aumento frequentemente é acompanhado pela ampliação da área ocupada em relação à reportagem.

A subordinação ao texto aponta uma direção editorial quanto à função do infográfico quanto menos dependente, mais ele é visto como uma narrativa jornalística (e não como um elemento ilustrativo). 


\section{Independência}

\begin{tabular}{c|l}
\hline 1 & $\begin{array}{l}\text { Infográfico é elemento pouco significativo de reportagem. Conteúdo repete, sem } \\
\text { vantagem, informações apresentadas em elementos predominantes (como o texto } \\
\text { principal). Poderia ser removido sem prejuízo significativo. }\end{array}$ \\
\hline $\mathbf{1}$ & $\begin{array}{l}\text { Conteúdo é tangente ao assunto da reportagem ou repetido, mas compõe mensagem } \\
\text { completa e significativa. }\end{array}$ \\
\hline $\mathbf{3}$ & $\begin{array}{l}\text { Há equilíbrio de área e conteúdo, estabelecendo relação de complementaridade entre } \\
\text { infográfico e demais elementos da reportagem. Remoção do infográfico prejudicaria } \\
\text { mensagem, mas demais componentes são também necessários. }\end{array}$ \\
\hline $\begin{array}{l}\text { Infográfico é responsável pelo total ou porção mais importante do conteúdo, não } \\
\text { dependendo de mais elementos. }\end{array}$
\end{tabular}

\subsubsection{Eixo enciclopédico-específico}

Infográficos enciclopédicos têm caráter mais universal, representando conhecimentos estabelecidos; infográficos específicos apresentam mais atualidade e relação mais estreita com o fato noticiado (um exemplo citado pela autora é o caso de acidentes reconstituídos a partir de depoimentos).

Infográficos enciclopédicos podem ser adaptados para outras notícias - dentro da mesma cobertura, por exemplo. Além disso, apresentam teor mais didático, menos noticioso. Já a produção de material específico é mais urgente e exige a existência de equipe voltada a esse trabalho. Assim, esse eixo ajuda a identificar a importância atribuída a esse tipo de linguagem em um veículo jornalístico.

\section{Especificidade}

Infográfico apresenta conhecimento atemporal ou bastante anterior à reportagem

(sem atualidade ou valor noticioso).

Exemplos: explicações técnicas ou científicas estabelecidas (em reportagens que não enfatizam esse caráter), mapas localizando regiões geográficas (sem acontecimentos). Formato padronizado preenchido com dados novos.

ou

1 Infográfico de conhecimento atemporal com pequeno valor de novidade.

Exemplos: resumo de partidas de futebol, perfil de entrevistados, mapas com notações simples indicando acontecimentos.

Ligação com fato noticioso é um pouco elástica. Pode apresentar contextualização de acontecimento em andamento ou paralelo com casos semelhantes.

2 ou

Diagrama de complexidade moderada com informação conhecida, mas necessária à abordagem. 


\section{Especificidade}

\begin{tabular}{l|l}
\hline & $\begin{array}{l}\text { Exemplos: resumo dos acontecimentos anteriores, explicação sobre cúpula na qual } \\
\text { debate ocorreu, relato de investigação criminal na cobertura de julgamento. }\end{array}$ \\
\hline $\mathbf{3}$ & $\begin{array}{l}\text { Infográfico extremamente próximo ao fato noticioso. Reforça a abordagem da } \\
\text { reportagem, preferencialmente destacando informações novas ou representando o } \\
\text { próprio acontecimento. } \\
\text { ou } \\
\text { Diagrama complexo necessário para abordagem proposta, ainda que com valor } \\
\text { noticioso limitado. } \\
\text { Exemplos: representação de acidente aéreo, variação de inflação no período. }\end{array}$
\end{tabular}

\subsubsection{Eixo estetizante-analítico}

Infográficos estetizantes têm função de atrair a atenção do leitor e valorizar o aspecto gráfico de uma página; infográficos analíticos buscam possibilitar leituras aprofundadas e ampliar a compreensão. Segundo Cairo (2008, p. 29), a infografia estetizante predomina no cenário atual, mas a analítica estaria ganhando espaço em jornais como The New York Times.

A análise envolveu novamente escala de o a 3 pontos; no entanto, essa análise exigiu o uso de mais critérios, resultando em uma combinação de escalas.

Isso se deve ao fato de que o valor estético e o valor analítico não são, na verdade, excludentes. Cuidados gráficos podem reforçar a memorização ou mesmo organizar relações e análises. Em muitos casos, o infográfico com função estetizante tem baixo valor estético - ele apenas ajuda a dinamizar a página por apresentar uma estrutura formal diferenciada do texto corrido. Gráficos com conteúdo complexo muitas vezes recebem mais trabalho de caráter estético porque demandam mais atenção da equipe de arte do veículo em sua construção.

Para orientar esta análise, foram encontradas duas propostas de estruturação das qualidades essenciais do design da informação. A primeira, de Mijksenaar (1997, p. 18) ${ }^{71}$, se baseia na tríade Firmitas-Utilitas-Venustas ${ }^{72}$, de Vitruvius, que permeia o campo do design. Mijksenaar atualiza os rótulos, mas reitera a indissociabilidade dos três elementos: confiabilidade, satisfação e utilidade. Dessa forma, o infográfico (que é uma aplicação do design da informação no jornalismo) não deve negligenciar nenhum desses elementos.

Embora atual, o diagrama de Mijksenaar mostrou-se limitado ao ser transposto ao jornalismo ${ }^{73}$. Embora alguns conceitos possam ser adaptados (a confiabilidade, por exemplo,

71 A adoção da proposta de Mijksenaar como metodologia foi realizada por Schmid (2006) em dissertação de mestrado apresentada à ECA. A autora admite não haver "uma metodologia de cálculo dos diferentes fatores envolvidos na representação dos três eixos” (2006, p. 97) e optou pela contagem de todos os elementos de uma página impressa. 72 Os três conceitos podem ser traduzidos, respectivamente, como durabilidade, utilidade, beleza.

73 As características do jornalismo exigem adaptações de princípios de autores do design da informação. Cleveland 
pode ser relacionada com a precisão e a credibilidade de um veículo), a fórmula tripartida dá pouca ênfase ao conteúdo transmitido em uma reportagem jornalística.

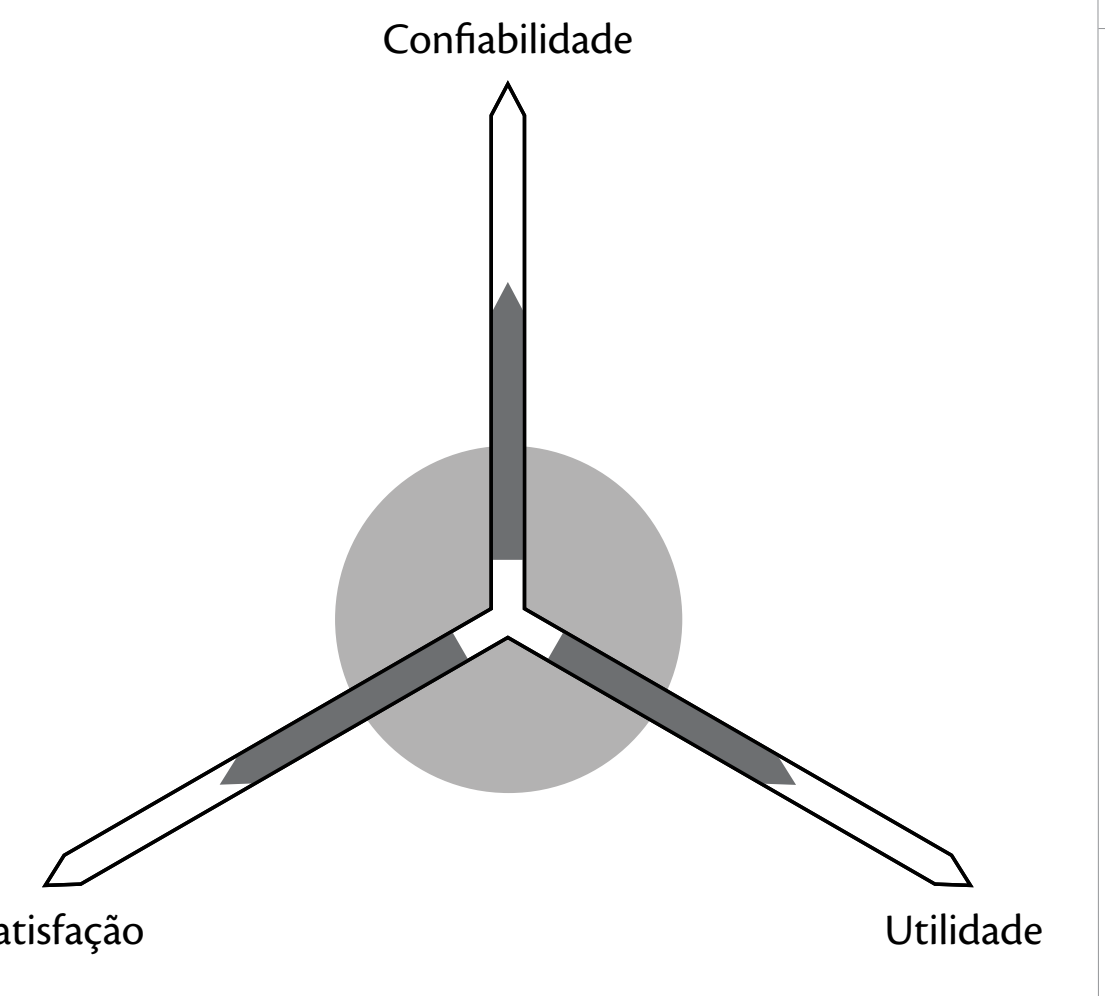

\section{A fórmula tripartida}

Recuperando princípios

clássicos, Mijksenaar

propõe que elementos

de design sejam

analisados em suas

três qualidades:

confiabilidade, utilidade

e satisfação.

O infografista McCandless (2009b), por sua vez, propôs um diagrama com quatro elementos: integridade, forma, função e interestingness ${ }^{74}$. De acordo com sua definição, "informação precisa ser interessante ${ }^{75}$ (significativa e relevante) e ter integridade (precisão e consistência). Design precisa ter forma (beleza e estrutura) e função (precisa funcionar e ser "fácil de usar".

Apesar de ter relacionado integridade à informação, parte do diagrama de McCandless tem parentesco com os princípios de Vitruvius. O quarto elemento, denominado interestingness, é um atributo de conteúdo que pressupõe novidade, significado e relevância.

(1994, p. 262) critica gráficos do tipo pizza ou similares no formato de barra empilhada. Segundo ele, as pop charts têm menor eficiência perceptiva que um gráfico de pontos (dot plot) - mas seu uso na imprensa é mais comum e, por isso, reconhecido pelos leitores. Tufte (2007, p. 100) defende a eliminação da redundância na representação gráfica de dados. Entretanto, a infografia codifica a mesma informação mais de uma vez - utilizando simultaneamente setas e numeração, ou símbolos e cores - porque o jornalismo busca transmitir a informação em situações de ruído.

74 Neologismo sem tradução (transformação do adjetivo interesting em substantivo, mas diferente de interest) que se relaciona a "ser interessante".

75 McCandless (2009a, p. 7) defende que a informação ganha significado quando é trabalhada de forma menos direta e "seca", enfatizando o contexto e as conexões dos dados. 


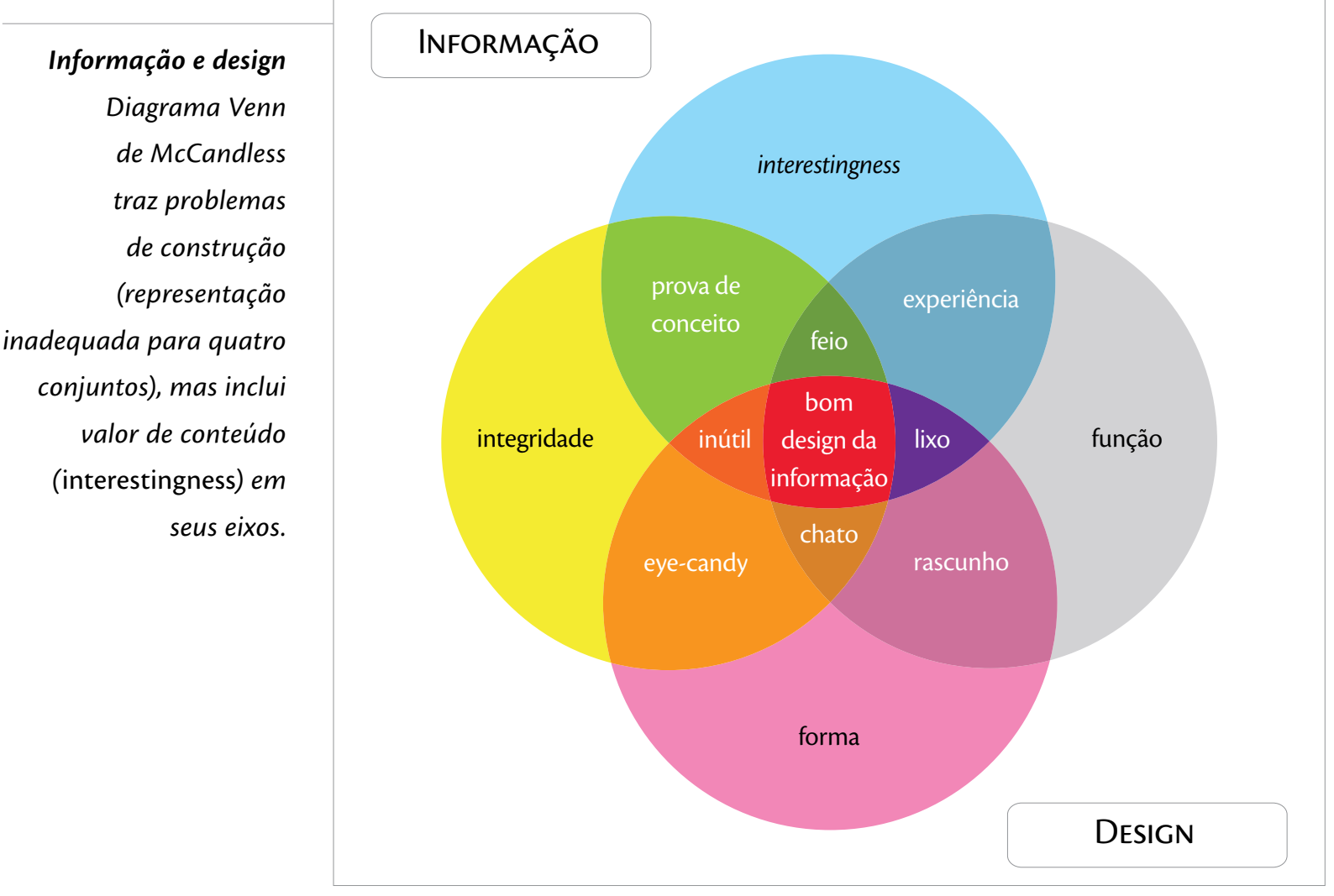

Para McCandless, somente a intersecção dos quatro elementos pode gerar uma peça bem-sucedida de design da informação. A ausência de dois elementos ocorre em peças nãoacabadas $^{76}$, enquanto a ausência de apenas um elemento tem graves consequências para a comunicação. A falta de integridade produz gráficos imprecisos e até mesmo desonestos; negligenciar a função traz dificuldades de compreensão; pouca atenção à forma gera desagrado ou mera falta de atenção; falta de interestingness resulta em um gráfico sem conteúdo, chato.

O diagrama de $\mathrm{McCandless} \mathrm{é} \mathrm{um} \mathrm{rascunho} \mathrm{e} \mathrm{apresenta} \mathrm{erros} \mathrm{de} \mathrm{construção}{ }^{77}$, mas aponta uma direção apropriada para a verificação de infográficos jornalísticos: a importância do interesse (ou do conteúdo). $O$ infográfico analítico não precisa minimizar a qualidade da apresentação visual (forma), mas não pode descuidar da qualidade da informação transmitida.

A partir da proposta de McCandless, foi desenvolvido na pesquisa um conjunto de quatro elementos que devem estar presentes em infográficos: integridade, usabilidade, estética e conteúdo. Cada um desses elementos é complexo e exige três subdivisões. Dessa forma, cada infográfico pode ser descrito na forma de um gráfico de barras com quatro valores combinados.

76 Apesar de McCandless defender que tais peças sejam interessantes, os rótulos usados pelo autor - "rascunho", “experimento", "prova de conceito" e "eye-candy" - denunciam que elas não são completas.

77 O diagrama de Venn construído por McCandless não contempla certas inteseções simples (como forma + interestingness e função + integridade); um diagrama correto para quatro conjuntos poderia ter a forma representada ao lado.

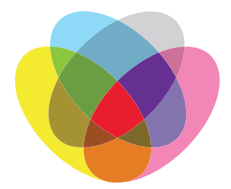




\section{a) Integridade}

A integridade do infográfico se relaciona com confiabilidade no jornalismo, abrangendo os dados e sua representação. Nesse elemento, são verificados:

- Precisão: os dados representados devem estar corretos e conter informação sobre sua origem $^{78}$. Dados incorretos desinformam o leitor. Já a indicação de fonte dos dados é necessária para que o leitor possa examinar a validade e interesses relacionados a essa informação. Por fim, a apresentação do crédito é uma prática esperada no jornalismo tanto pelo reconhecimento do trabalho do profissional como pelo interesse do leitor, já que fornece subsídios para avaliação similares aos da informação sobre fonte dos dados.

- Clareza: a ambiguidade deve ser evitada não apenas na redação de sentenças, mas também na representação gráfica. Se esse atributo estiver falho, o leitor pode ter dúvidas ou mesmo apreender informações incorretas.

- Escala: a representação gráfica é memorável. Um gráfico com rótulos numéricos corretos, mas com representação irregular pode levar o leitor a fazer interpretações a partir de informações equivocadas.

\section{Precisão (I1)}

\begin{tabular}{c|l}
\hline & Grande quantidade de erros, afetando pontos centrais. \\
\hline 1 & Há dados incorretos ou em situação duvidosa, mas sem afetar pontos centrais. \\
\hline 3 & $\begin{array}{l}\text { Ou infográfico traz alguns dados incorretos, mas com consequências leves. } \\
\text { Dados corretos, mas sem indicação importante de fonte ou crédito. }\end{array}$ \\
\hline 2 Preferencialmente, também apresenta crédito de produção.
\end{tabular}

Clareza (I2)

\begin{tabular}{c|l}
\hline 1 & $\begin{array}{l}\text { Questões centrais estão mal representadas e podem facilmente ser interpretadas de } \\
\text { forma incorreta. }\end{array}$ \\
\hline 1 & $\begin{array}{l}\text { Gráficos, ícones e termos são ambíguos e podem gerar dúvidas em questões } \\
\text { secundárias. }\end{array}$ \\
\hline 2 & $\begin{array}{l}\text { Gráficos, ícones e termos foram escolhidos adequadamente, mas complexidade do } \\
\text { infográfico exige atenção do leitor para evitar mal-entendidos. }\end{array}$ \\
\hline
\end{tabular}

78 A indicação de fonte não é necessária em casos nos quais os dados são obtidos pela observação do repórter, como resumos de partidas de futebol. 


\section{Clareza (I2)}

\section{O significado do infográfico é compreendido rapidamente e não gera dúvidas.}

Escala (I3)

\begin{tabular}{c|l}
\hline $\mathbf{1}$ & $\begin{array}{l}\text { Problemas de escala e proporção alteram significados, invertendo relações e } \\
\text { comprometendo informaçoes centrais. }\end{array}$ \\
\hline $\mathbf{2}$ & $\begin{array}{l}\text { Há desvios de escala e proporção, mas de baixa intensidade. } \\
\text { ou alguma acomodação na escala, mas moderada ou com notificação. } \\
\text { Não há uso de escala ou proporção. }\end{array}$ \\
\hline $\mathbf{3}$ & A escala é usada de forma correta, trazendo significação clara na primeira leitura.
\end{tabular}

b) Usabilidade

A usabilidade é "um atributo de qualidade que avalia a facilidade de uso de interfaces" (Nielsen, 2003). Ela é definida por cinco componentes: facilidade de aprendizado, eficiência, facilidade de memorização, índice de erros e satisfação.

Em um infográfico (que é uma manifestação do design da informação), a usabilidade possibilita a recuperação da informação de forma eficaz e eficiente. Assim, espera-se que um infográfico tenha seu funcionamento compreendido rapidamente e de forma permanente, permitindo a leitura e análise com eficiência. Além disso, deve minimizar a possibilidade de leituras incorretas e evitar a frustração do leitor. Essas características são verificadas em três frentes:

- Legibilidade e percepção visual: o reconhecimento de caracteres, cores, símbolos e gráficos é vital para permitir a leitura. Esses mesmos recursos também ajudam a hierarquizar a informação.

- Organização: entradas de leitura devem estar claras, assim como a ordem (no caso de composições que exijam leitura em sequência). A organização adequada dos elementos ajuda a reconhecer temas e graus de importância.

- Formato: não existem regras absolutas, mas uma representação pode ser mais ou menos adequada para cada informação. A proposta de Roam (2008, p. 133) faz relações entre o tipo de informação e o tipo de representação - sugerindo, entre outros casos, que gráficos quantitativos sejam usados para representar dados numéricos. Mas o quadro é simplificado, não templando certas sutilezas. Por exemplo: gráficos de linha ou febre representam variações quantitativas ao longo do tempo; gráficos de barra ajudam a comparar valores quantitativos de personagens ou categorias diferentes. 


\section{Legibilidade e percepção visual (U1)}

\begin{tabular}{c|l}
\hline 1 & Problemas de impressão ou contraste dificultam ou impedem a leitura. \\
\hline $\mathbf{1}$ & Há algum problema de reconhecimento gráfico, mas a leitura é pouco prejudicada. \\
\hline $\mathbf{3}$ & $\begin{array}{l}\text { Boa legibilidade de porções textuais; ícones e gráficos são facilmente reconhecíveis. } \\
\text { Recursos são utilizados para organizar a informação em níveis. }\end{array}$ \\
\hline
\end{tabular}

Organização (U2)

\begin{tabular}{c|l}
\hline 1 & $\begin{array}{l}\text { É difícil encontrar informações relevantes (ponto central, interesse específico) e } \\
\text { navegar entre seções; faltam instruções. }\end{array}$ \\
\hline $\mathbf{1}$ & $\begin{array}{l}\text { Os pontos centrais não estão identificados de forma clara; é difícil identificar seções } \\
\text { de interesse específico. }\end{array}$ \\
\hline $\mathbf{3}$ & $\begin{array}{l}\text { Boa organização para leitura, mas sem valor hierárquico. } \\
\text { Organização adequada, mas complexidade gera a necessidade de instruções. }\end{array}$ \\
\hline $\begin{array}{l}\text { Distribuição espacial, rótulos, legendas e sinais (setas, numeração) facilitam a leitura } \\
\text { rápida. É possível identificar facilmente pontos centrais e níveis de informação. }\end{array}$
\end{tabular}

\section{Formato (U3)}

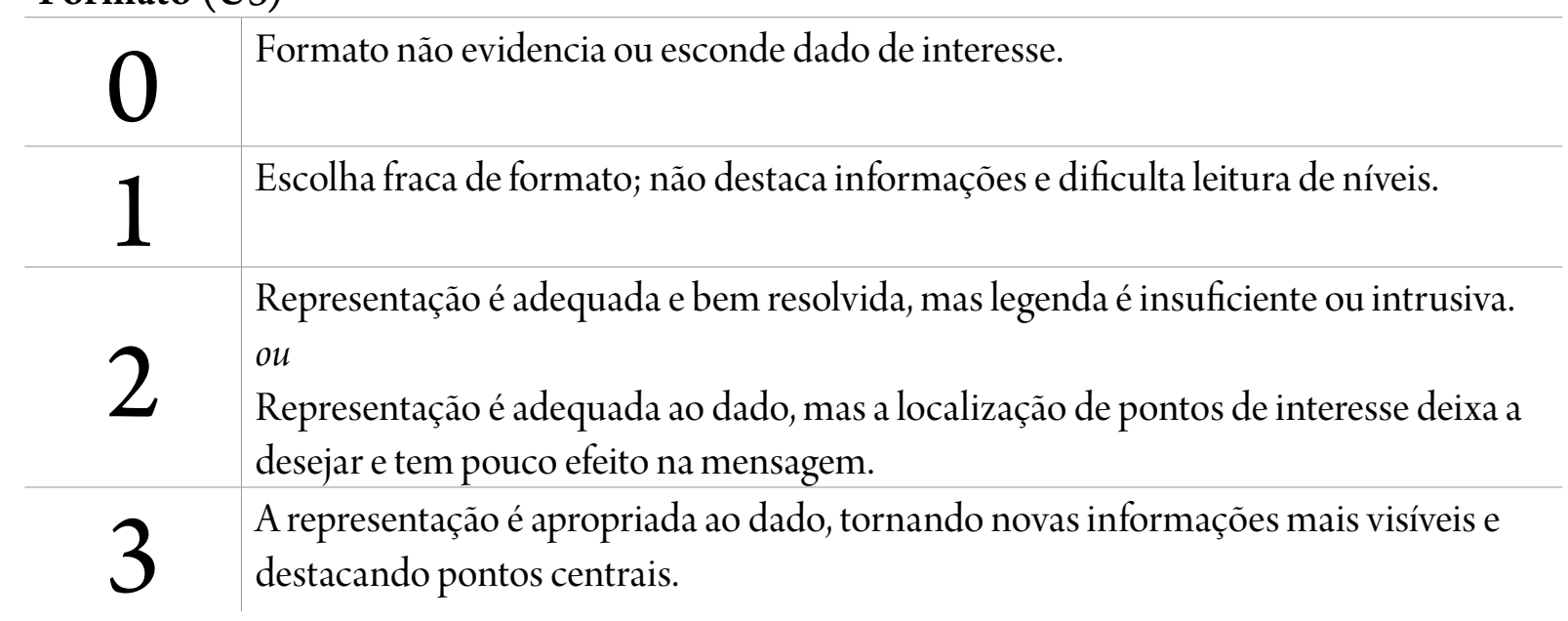

c) Aparência

Este elemento se preocupa com a estética do infográfico, mas não apenas por sua influência na atração do olhar do leitor. Um bom trabalho estético faz uso de ícones e representações que indicam e fixam o assunto abordado, e também reforça o valor da informação veiculada. 
As três características avaliadas são:

- Atratividade: o processo comunicativo de um infográfico só pode ser concluído se o leitor recebe a informação. De acordo com pesquisa do instituto Poynter (2007), narrativas usando elementos gráficos diferenciados mostram melhores resultados que narrativas textuais comuns. Por isso, o impacto visual de um infográfico pode aumentar as chances de leitura.

- Comunicação visual: representações imagéticas são consideradas mais próximas da realidade que representações verbais, permitindo comunicação mais imediata. Assim, ilustrações, ícones e cores podem indicar temas e tornar as informações mais memoráveis.

- Valor: cuidado com infográfico agrega valor à cobertura e ao veículo. A qualidade de produção - alinhamento, organização visual, traçados, acabamento - e de impressão afeta a percepção do leitor, podendo conferir confiabilidade ou dúvida às informações.

\section{Atratividade (A1)}

\begin{tabular}{c|l}
\hline 1 & $\begin{array}{l}\text { Infográfico muito pequeno e de pouco impacto visual; predomínio de elementos } \\
\text { textuais }\end{array}$ \\
\hline 1 & $\begin{array}{l}\text { Infográfico muito pequeno ou de impacto visual reduzido devido à maior } \\
\text { quantidade de elementos textuais }\end{array}$ \\
\hline 2 & $\begin{array}{l}\text { Infográfico ocupa área considerável, mas tem pouco impacto pela falta de recursos } \\
\text { visuais fortes ou pelo excesso de texto. } \\
\text { ou } \\
\text { Infográfico tem elementos visuais atraentes, mas sua área é reduzida. }\end{array}$ \\
\hline 3 & $\begin{array}{l}\text { Contraste, dimensões e ilustrações atraem e fixam o olhar, tornando o infográfico } \\
\text { mais destacado na página. Uso adequado de cor, se houver, e de contraste. Conjunto } \\
\text { textual moderado. }\end{array}$ \\
\end{tabular}

\section{Comunicação visual (A2)}

\begin{tabular}{c|l}
\hline Não há uso de comunicação iconográfica. \\
\hline 1 & $\begin{array}{l}\text { Infográfico predominantemente textual, com algumas imagens ilustrativas de baixo } \\
\text { valor comunicativo. }\end{array}$ \\
\hline 2 & $\begin{array}{l}\text { Recursos imagéticos têm relação com assunto, mas são genéricos ou discretos, pouco } \\
\text { marcantes. }\end{array}$ \\
\hline 3 & $\begin{array}{l}\text { Cores, ícones e elementos visuais facilitam o reconhecimento do assunto e do } \\
\text { enfoque da reportagem. }\end{array}$ \\
\hline
\end{tabular}

Valor (A3)

Produção de baixa qualidade e com problemas de reprodução ou impressão. 
Valor (A3)

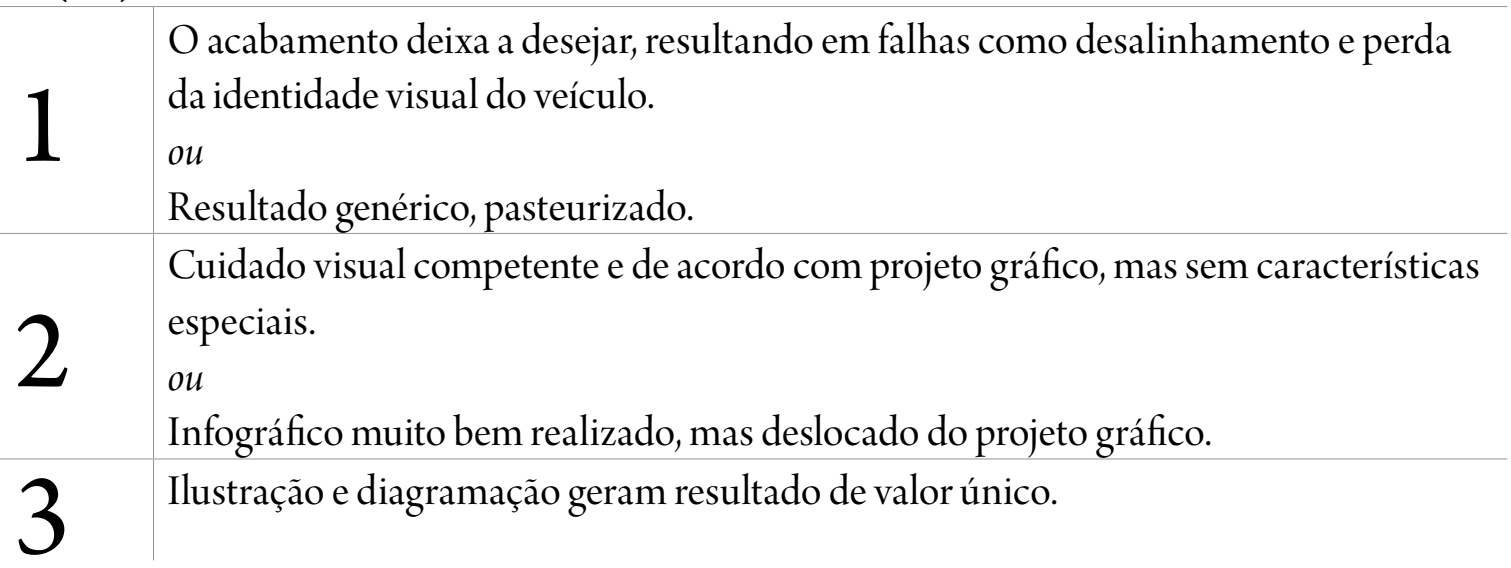

d) Conteúdo

Como peça jornalística, o infográfico tem sua essência no conteúdo. Ele compreende a mensagem que é transmitida, determinando a importância da leitura.

- Seleção: o interesse relacionado à leitura de um infográfico exige que a mensagem nele contida contemple os pontos mais relevantes de uma cobertura ou abordagem.

- Perspectivas: o uso de recursos de visualidade cria novas leituras e análises que não são visíveis ou são menos evidentes em narrativas textuais.

- Completude: mensagens completas têm níveis de informação e certo grau de complexidade. Se o recorte se restringe a apenas uma camada, há prejuízo de contexto e compreensão.

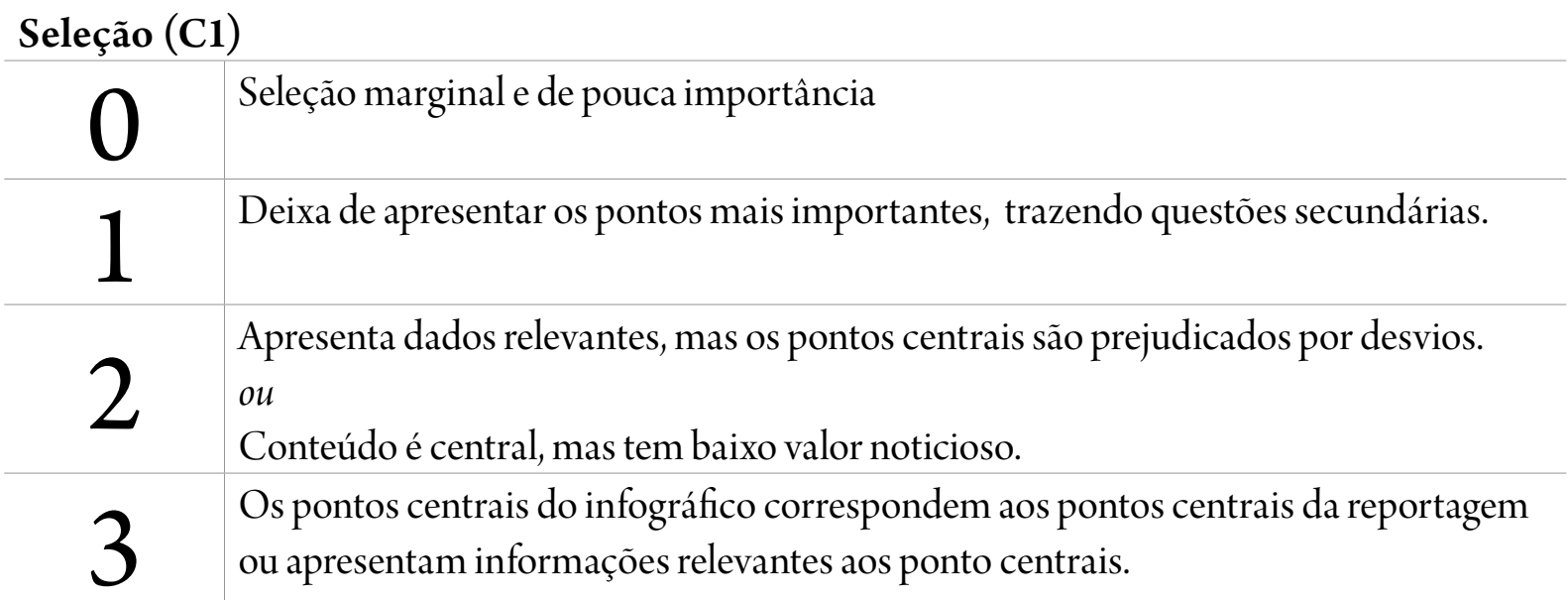

\section{Perspectivas (C2)}

\begin{tabular}{c|l}
\hline $\mathbf{l}$ & $\begin{array}{l}\text { Em vez de sumarizar, traz conteúdo longo e que não é favorecido pela apresentação } \\
\text { escolhida. }\end{array}$ \\
\hline 1 & $\begin{array}{l}\text { Informação é apresentada de forma pouco visual; edição organiza o conteúdo, mas } \\
\text { tem pouco efeito na mensagem. }\end{array}$ \\
\hline
\end{tabular}




\section{Perspectivas (C2)}

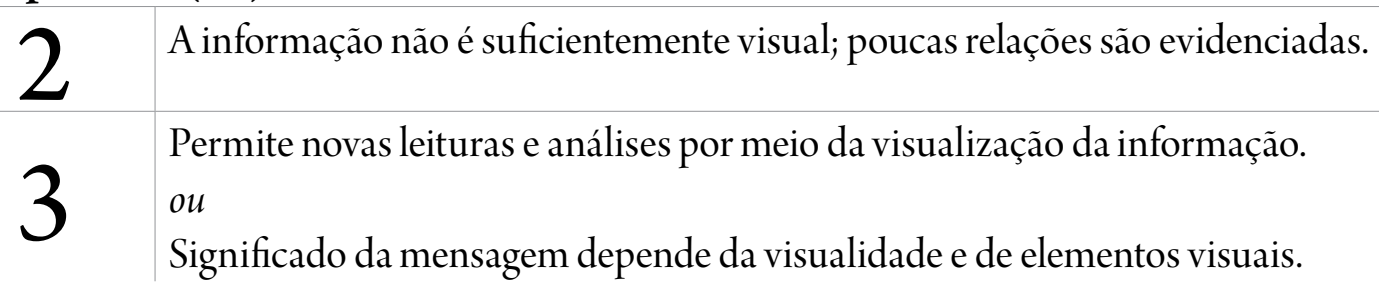

\section{Completude (C3)}

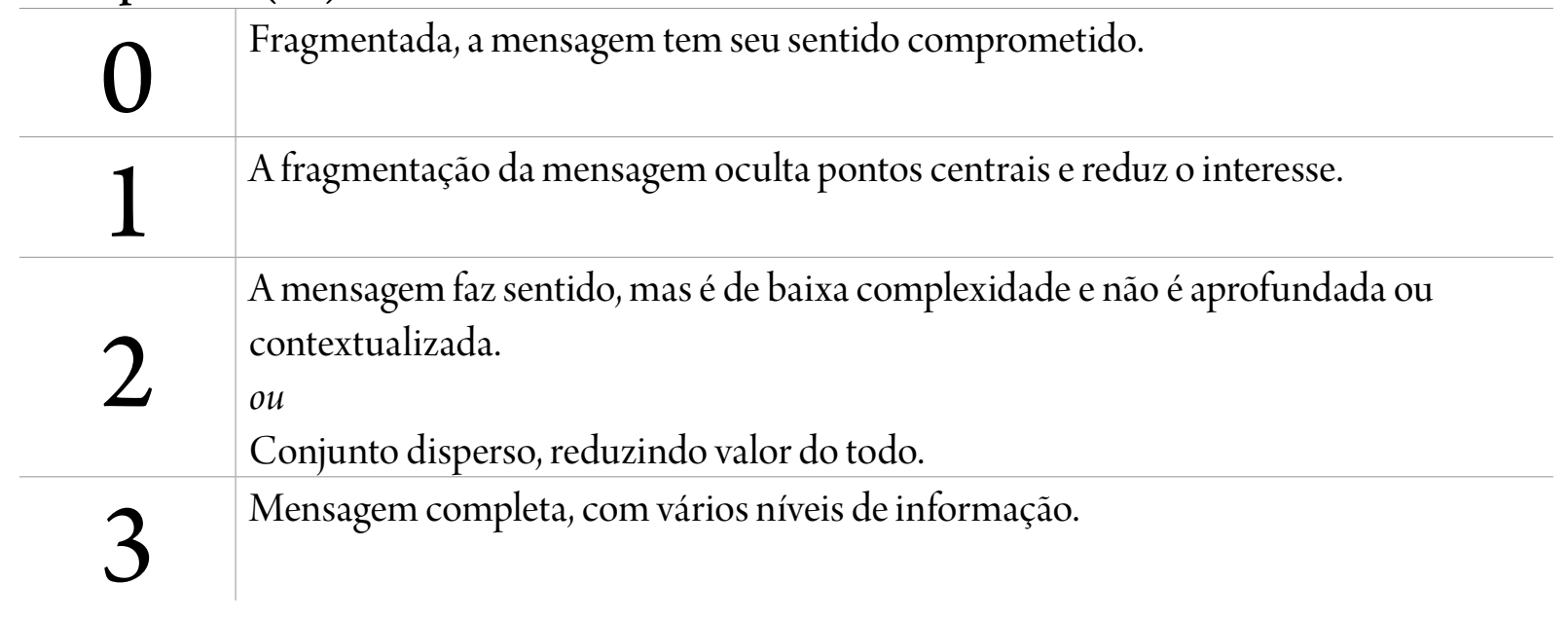

\subsection{EXEMPLO DE APLICAÇÃo DE CARACTERIZAÇÃo}

Com o objetivo padronizar a avaliação de infográficos, cada pontuação é delimitada de acordo com certas características. A descrição de pontuações também reduz a necessidade de justificativas na caracterização. Para esclarecimento, esse processo é aqui apresentado de forma detalhada.

Veículo: Galileu (abr./2009)

Título: O fim da Aids?

Página: 14

Editoria: Enter

Classificação: Saúde (SAU)

Descrição: Reportagem ocupa uma página inteira. Abaixo do título, linha fina e parágrafo de abertura cumprem função de introdução. Foto (seringa com fita-símbolo anti-Aids) grande e em posição de destaque tem papel ilustrativo - comprovado pelo crédito indicando serviço de imagens do tipo stock.

O conteúdo pode ser dividido em duas seções principais: 1) "Bem no alvo" - descrição do programa na forma de textos curtos; 2) "O que aconteceria..." - comparativos visuais de situação presente e projeção do programa após 10 anos. 


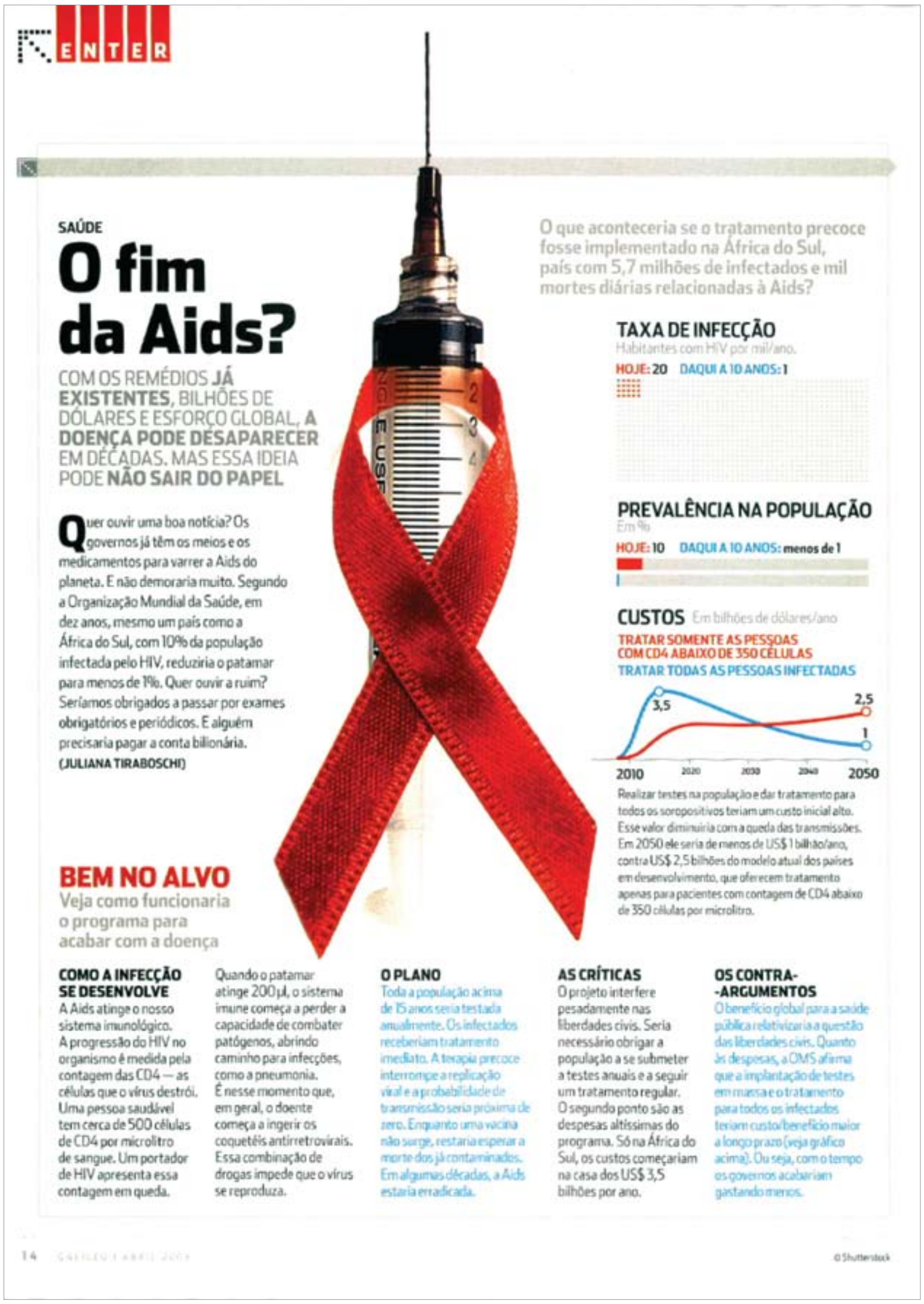




\section{Independência}
Descrição de critério
Infográfico é responsável pelo total ou porção mais importante do conteúdo, não
3 dependendo de mais elementos.
Aplicação na peça selecionada
O conjunto forma um infográfico desvinculado de outros elementos. Os
componentes verbais pertencem ao infográfico em funções de introdução e sumário.

\section{Especificidade}

\begin{tabular}{|c|}
\hline $\begin{array}{l}\text { Descrição de critério } \\
\text { Infográfico extremamente próximo ao fato noticioso. Reforça a abordagem da } \\
\text { reportagem, preferencialmente destacando informações novas ou representando o } \\
\text { próprio acontecimento. }\end{array}$ \\
\hline $\begin{array}{l}\text { Aplicação na peça selecionada } \\
\text { Conteúdo pode ser considerado novidade - ele destaca um programa novo, e } \\
\text { não informações já muito conhecidas ou divulgadas sobre a Aids. As simulações } \\
\text { representam a proposta que é o foco da reportagem. }\end{array}$ \\
\hline
\end{tabular}

\section{Integridade}

Descrição de critério

Os dados apresentados são corretos e, se adequado, têm origem indicada.

Preferencialmente, também apresenta crédito de produção.

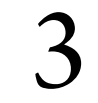

Aplicação na peça selecionada

Embora não esteja indicado de forma explícita ("Fonte:"), o texto informa que os

Precisão dados são da OMS. Após pesquisa entre publicações ligadas ao órgão, encontrouse o artigo que deu origem à reportagem (Granich, 2009), confirmando valores e projeções apresentadas.

O nome da repórter está indicado, mas não há crédito gráfico.

\section{Descrição de critério}

O significado do infográfico é compreendido rapidamente e não gera dúvidas.

3 Aplicação na peça selecionada

Clareza

As duas seções de conteúdo são bem identificadas. Na seção "O que aconteceria...", cada tipo de dado recebeu tratamento diferenciado, mas a codificação de cores consistente facilita a leitura. 


\section{Integridade}

Aplicação na peça selecionada

A representação de taxa de infecção é sobreposta (o $20^{\circ}$ ponto vermelho é encoberto pelo único ponto azul), o que exige hábito do leitor para compreender esse tipo de notação.

\section{Usabilidade}

Descrição de critério

Não há problemas de legibilidade ou reconhecimento de ícones, gráficos e cores.

\section{Aplicação na peça selecionada}

Legibilidade Elementos visuais e textuais são facilmente identificados. Traçados e cores têm valor comunicativo, identificando período ao qual o dado se refere, mas não conferem valor hierárquico significativo ao conjunto.

Descrição de critério

Boa organização para leitura, mas sem valor hierárquico.

\begin{tabular}{c|l}
2 & $\begin{array}{l}\text { Aplicação na peça selecionada } \\
\text { A distribuição espacial organiza a informação e permite que o leitor identifique } \\
\text { elementos, mas não há reforço visual de níveis de informação. A formatação da } \\
\text { Oçãão “Bem no alvo", por exemplo, parece criar diferenciação de caráter puramente } \\
\text { estético (a variação de cor de texto responde à alternância de blocos de texto, e não a } \\
\text { significações ou ênfase). }\end{array}$ \\
\hline 3 & $\begin{array}{l}\text { Descrição de critério } \\
\text { Arepresentação é apropriada ao dado, tornando novas informações mais visíveis e } \\
\text { destacando pontos centrais. }\end{array}$ \\
\hline Formato & $\begin{array}{l}\text { Aplicação na peça selecionada } \\
\text { Cada dado quantitativo recebeu tratamento gráfico adequado - a taxa de infecção } \\
\text { em mil/ano é mostrada em contexto, a prevalência é um valor de acúmulo e a } \\
\text { variação de custos acompanha componente temporal. }\end{array}$
\end{tabular}

\section{Aparência}

Descrição de critério

Contraste, dimensões e ilustrações atraem e fixam o olhar, tornando o infográfico mais destacado na página. Uso adequado de cor, se houver, e de contraste. Conjunto 3 textual moderado. conteúdo). Conjunto de gráficos reforça e gera curiosidade. 


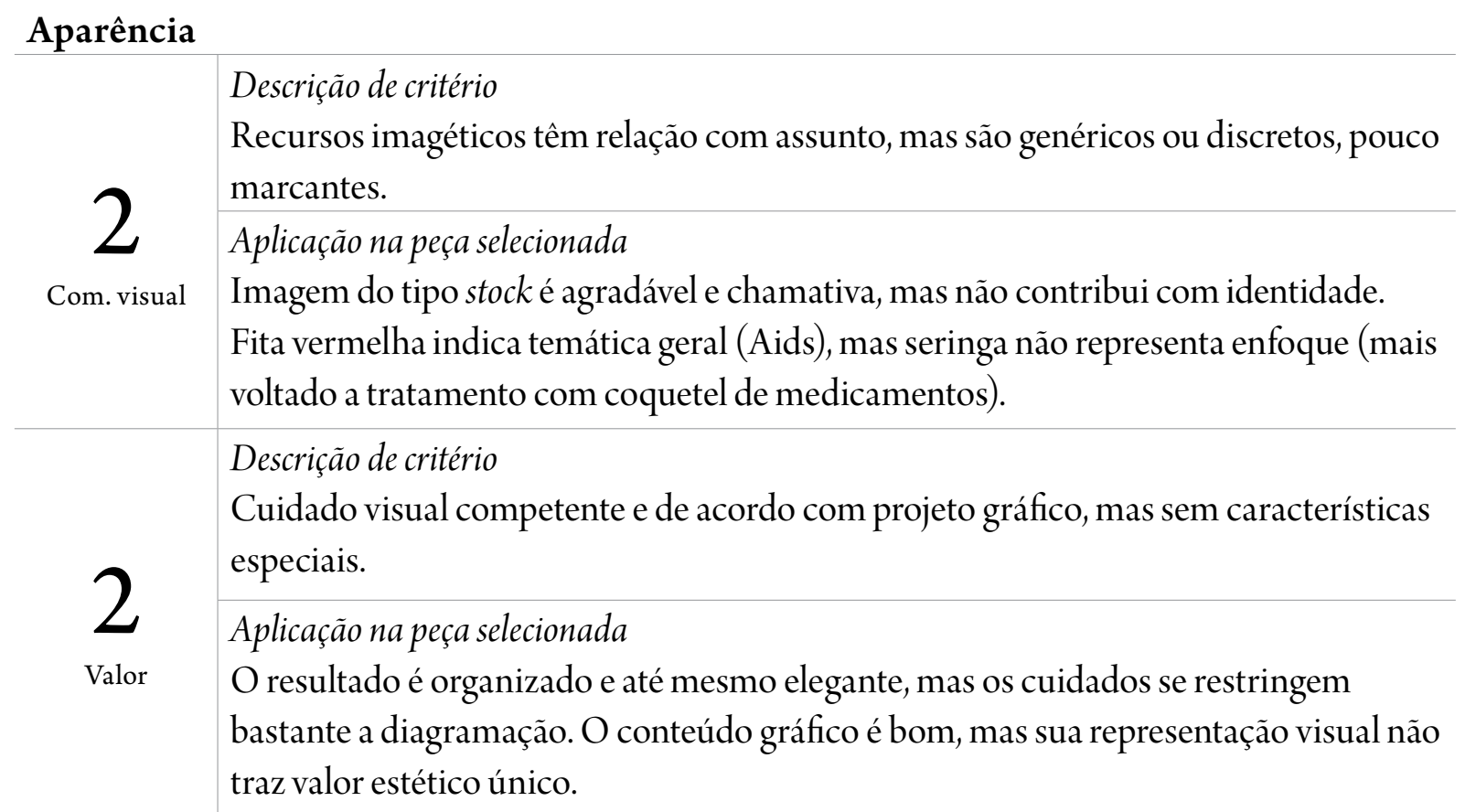

\section{Conteúdo}

\begin{tabular}{c|l}
\hline 3 & $\begin{array}{l}\text { Descrição de critério } \\
\text { Os pontos centrais do infográfico correspondem aos pontos centrais da reportagem } \\
\text { ou apresentam informações relevantes aos ponto centrais. }\end{array}$ \\
Seleção & $\begin{array}{l}\text { Aplicação na peça selecionada } \\
\text { A abordagem destaca um plano para controle da propagação da Aids. Assim, o } \\
\text { conteúdo do infográfico representa sua descrição e efeitos. }\end{array}$ \\
\hline 3 & $\begin{array}{l}\text { Descrição de critério } \\
\text { Permite novas leituras e análises por meio da visualização da informação. }\end{array}$ \\
\hline Perspectivas & $\begin{array}{l}\text { Aplicação na peça selecionada } \\
\text { Mesmo com componente textual significativo, o conjunto gráfico enfatiza a } \\
\text { informação de forma visual, permitindo análise. }\end{array}$ \\
\hline $\mathbf{3}$ & $\begin{array}{l}\text { Descrição de critério } \\
\text { Mensagem completa, com vários níveis de informação. }\end{array}$ \\
\hline Completude & $\begin{array}{l}\text { Aplicação na peça selecionada } \\
\text { Conteúdo bastante abrangente. O plano é apresentado com detalhes, e sua aplicação } \\
\text { é mostrada em exemplo. }\end{array}$
\end{tabular}

Comentário: Reportagem infográfica destaca informações novas de forma independente. Boa integridade devido ao uso de fonte respeitada e correção de dados, ainda que com pequeno problema de representação quantitativa. A apresentação dos dados favorece a compre- 
ensão, mas não enfatiza conteúdos. A aparência é cuidadosa, embora seja prejudicada pela falta de identidade visual. O conteúdo respeita proposta apresentada na introdução e faz uso da visualidade para promover análises. 



\section{ANÁliSE DE INFOGRÁFICOS}

Bastante utilizada no campo das comunicações, a análise de conteúdo é um conjunto de técnicas de perspectiva quantitativa para a obtenção e comparação de dados, permitindo a detecção de tendências e modelos. Por isso, se mostra apropriada para recolher e analisar informações sobre um elemento próprio da linguagem jornalística.

De acordo com levantamento de Neuendorf (2002, p. 1, tradução nossa), a análise de conteúdo tem aplicação ampla, compreendendo desde estudos sobre coberturas jornalísticas de tópicos de interesse à "análise de Johnson (1987) dos vocalismos do [personagem de desenho animado] Gaguinho a partir de um ponto de vista clínico fonoaudiológico". A autora também defende que a análise de conteúdo não se restringe a textos verbais escritos, podendo ser aplicada a outros tipos de mensagens - incluindo as visuais (Neuendorf, 2002, p. 24).

A análise realizada tem como objetivo validar o método de caracterização apresentado. Para isso, os procedimentos foram aplicados em veículos jornalísticos, caracterizando seus infográficos. Os dados gerados também permitem análise sobre o uso desse elemento em veículos noticiosos de interesse geral, que formam o corpo de pesquisa.

\subsection{DefiniÇão do CORPo DE PESQUisa}

A análise de conteúdo exige "definir em detalhes quais jornais seriam incluídos no estudo, qual o período de análise, quantas colunas seriam analisadas e que aspectos de conteúdo seriam observados" (Herscovitz, 2008, p. 129).

Para a realização da análise, o corpo da pesquisa é composto por cinco jornais diários e duas revistas semanais, representando veículos noticiosos impressos de interesse geral.

Os jornais selecionados são: Folha de S. Paulo, O Estado de S. Paulo, Agora São Paulo, Diário de São Paulo e Jornal da Tarde. Optou-se por estudar cinco jornais da mesma localidade porque o grupo representa títulos voltados a diferentes tipos de público e com níveis diferentes de tiragens. Estão compreendidas entre eles três empresas jornalísticas de destaque no cenário nacional: os grupos Folha, Estado e Globo ${ }^{79}$. Além disso, Folha de S. Paulo e O Estado de S. Paulo são jornais de alcance nacional, embora sediados em São Paulo.

As revistas semanais Veja e Época, concorrentes diretas, têm grande repercussão entre leitores do país todo - embora as duas redações também estejam localizadas na cidade de São Paulo. Devido à diferença de periodicidade, a revista semanal informativa também tem funções e linguagens diferentes em relação ao jornal diário, além de permitir maior período para a con-

79 O jornal Diário de São Paulo pertencia à empresa Infoglobo no início da pesquisa; em outubro de 2009, ele foi vendido ao Grupo Traffic, empresa que também possui a rede de jornais Bom Dia. 
fecção de reportagens - e, consequentemente, de infográficos. Os dois títulos selecionados também representam as duas principais editoras do mercado de revistas - Abril e Globo ${ }^{80}$.

O recorte da amostragem compreende três dias aleatórios com intervalo aproximado de 6 meses - incluindo-se os jornais do dia e as revistas do período correspondente.

\begin{tabular}{|c|c|c|c|}
\hline & Grupo 1 & Grupo 2 & Grupo 3 \\
\hline Jornais & 19/abr./2009 & 27/out./2009 & 23/abr./2010 \\
\hline Revistas & $\begin{array}{l}\text { 20/abr./2009 (Época) } \\
\text { 22/abr./2009 (Veja) }\end{array}$ & $\begin{array}{l}\text { 26/out./2009 (Época) } \\
\text { 28/out./2009 (Veja) }\end{array}$ & $\begin{array}{l}\text { 19/abr./2010 (Época) } \\
\text { 21/abr./2010 (Veja) }\end{array}$ \\
\hline
\end{tabular}

\subsubsection{Materiais analisados}

De acordo com a definição apresentada, um infográfico deve apresentar as seguintes características:

a) Ser vinculado a conteúdo jornalístico;

b) Representar dados de forma diagramática;

c) Promover a visualidade da informação.

A primeira característica é facilmente verificada no corpo de pesquisa, composto de veículos jornalísticos. Mesmo assim, algumas restrições se aplicam ao conteúdo desses veículos:

- O conteúdo jornalístico exclui a publicidade;

- Seções diversas como "Resumo de novelas", "Horóscopo”, ensaios de moda e passatempos não são consideradas jornalísticas por não se alinharem às funções e finalidade do jornalismo, apresentadas anteriormente;

- O infográfico não é uma ferramenta de diagramação ${ }^{8_{1}}$ de notícias.

Também foram excluídos da análise seções como previsão do tempo e listas de mais vendidos, cujo uso se cristalizou como componente fixo de um veículo jornalístico. Outros formatos rejeitados são o de galerias de compras (sugestões de produtos não são conteúdo jornalístico) e o chamado agate $e^{82}$ - tabelas fixas de números comuns nas coberturas esportiva e financeira que representam dados desvinculados do trabalho de reportagem.

80 A revista Isto É não foi analisada por ser menos influente e não apresentar contribuições diferentes em sua infografia. Além disso, a Editora Três tem menor porte e catálogo menos significativo que as editoras de Veja e Época. A inclusão da Isto É reduziria o caráter comparativo entre os dois títulos selecionados.

81 Alguns veículos impressos adotar diagramação diferenciada de seções fixas, como a página "Folha Corrida”, do jornal Folha de S. Paulo, e o espaço “12 Horas”, da revista Época. Nessas situações, o formato tem finalidade de distribuição e apresentação da informação, mas sem preocupação narrativa.

82 Na terminologia tipográfica, “agate” é a unidade referente a 5.5 pontos. Esse valor foi considerado o menor corpo aceitável para impressão, passando a ser usado em extensas tabelas publicadas em jornais. Essas tabelas então ficaram conhecidas pelo mesmo nome - "agate". 
A segunda característica segue posicionamento de Holmes (Heller, 2006, p. 37), englobando narrativas que fogem ao formato linear convencional. Essa descrição compreende desde diagramas bastante ilustrados a sumários sem componentes figurativos.

Já a terceira característica diz respeito ao propósito do diagrama. Assim, o sucesso alcançado por cada item analisado varia, mas os infográficos analisados mostram finalidade de melhorar o índice de leitura e a compreensão do conteúdo.

\subsection{Procedimento}

Uma reportagem é um conjunto, e cada um de seus componentes - texto, retranca, foto, ilustração, infográfico - não pode ser analisado de forma individual. Por isso, a análise foi feita a cada reportagem com componente infográfico.

O processo de leitura é organizado a partir de um guia de análise e seu formulário correspondente (Neuendorf, 2002, p. 132). O guia é um documento que explica os critérios adotados, enquanto o formulário oferece espaços de preenchimento para cada variável explicada.

\subsubsection{Guia de análise}

O guia de análise serve como um manual de instruções, orientando o preenchimento do formulário. Nesta análise, o guia corresponde aos critérios apresentados no método de caracterização (capítulo 6). As tabelas descrevem características correspondentes a cada pontuação, uniformizando a análise e reduzindo a ocorrência de variação ${ }^{83}$.

\subsubsection{Formulário de análise}

O formulário utilizado apresenta os seguintes espaços:

a) Identificação

Esta seção reúne dados para identificação e localização da peça analisada.

\begin{tabular}{l|l|l|l|l} 
Código & Reportagem & Página & Editoria & Categoria
\end{tabular}

O código indica o grupo, o veículo ${ }^{84} \mathrm{e}$ a ordem do infográfico. Exemplo: o código 1 AGRo13 indica a $13^{\mathrm{a}}$ peça encontrada na edição de 19/abr./2004 do jornal Agora São Paulo.

83 Os critérios de avaliação adotados nesta análise de conteúdo já haviam passado por etapas anteriores de pré-testes, que levaram a definições mais específicas para a pontuação. Refeitos, os primeiros testes apresentaram variação de $20,63 \%$. Com o guia final, o índice foi de $7,14 \%$.

84 A porção referente aos veículos é formada por três caracteres representando o título da publicação: AGR (Agora 
Cada reportagem (a unidade de análise) foi também descrita por seu título ${ }^{85}$, as páginas nas quais ela se distribui e a editoria de acordo com rotulação do veículo.

Para normalizar essa nomenclatura, cada reportagem também foi classificada nas seguintes categorias de conteúdo: Cidades (CID) ${ }^{86}$, Ciência e Tecnologia (CET), Comportamento (COM), Consumo (CON), Economia (ECN), Conteúdo editorial (EDT), Educação (EDU), Entretenimento (ENT), Esportes (ESP), Guerras e Catástrofes (GEC), Polícia e Criminalidade (PLC), Política (POL), Religião (REL), Saúde (SAU), Serviços (SRV), Viagem e Turismo (TUR).

b) Eixos de caracterização

\begin{tabular}{|c|c|c|c|c|c|c|c|c|c|c|c|c|c|}
\hline \multirow{3}{*}{$\begin{array}{l}\text { Subordinado } \\
\text { - Independente }\end{array}$} & \multirow{3}{*}{$\begin{array}{l}\text { Enciclopédico } \\
\text { - Específico }\end{array}$} & \multicolumn{12}{|c|}{ Estetizante - Analítico } \\
\hline & & \multicolumn{3}{|c|}{ Integridade } & \multicolumn{3}{|c|}{ Usabilidade } & \multicolumn{3}{|c|}{ Aparência } & \multicolumn{3}{|c|}{ Conteúdo } \\
\hline & & I1 & $\mathrm{I} 2$ & $\mathrm{I} 3$ & U1 & $\mathrm{U} 2$ & U3 & A1 & A2 & A3 & $\mathrm{C} 1$ & $\mathrm{C} 2$ & $\mathrm{C} 3$ \\
\hline
\end{tabular}

Cada campo recebe uma pontuação de o a 3, de acordo com os critérios de caracterização do guia de análise. No eixo estetizante-analítico, o formulário digital combina as três subdivisões de cada elemento, compondo gráfico de barra representando cada reportagem.

Assim, o exemplo apresentado em 6.2 receberia a seguinte representação:

\begin{tabular}{l|l|l|l|l|} 
Código & Reportagem & Página & Editoria & Categoria \\
\hline 1GALOO3 & O fim da Aids? & 14 & Enter & SAU
\end{tabular}

\begin{tabular}{|c|c|c|c|c|c|c|c|c|c|c|c|c|c|}
\hline \multirow{3}{*}{$\begin{array}{l}\text { Subordinado } \\
\text { - Independente }\end{array}$} & \multirow{3}{*}{$\begin{array}{l}\text { Enciclopédico } \\
\text { - Específico }\end{array}$} & \multicolumn{12}{|c|}{ Estetizante - Analítico } \\
\hline & & \multicolumn{3}{|c|}{ Integridade } & \multicolumn{3}{|c|}{ Usabilidade } & \multicolumn{3}{|c|}{ Aparência } & \multicolumn{3}{|c|}{ Conteúdo } \\
\hline & & I1 & $\mathrm{I} 2$ & $\mathrm{I} 3$ & U1 & $\mathrm{U} 2$ & U3 & A1 & A2 & A3 & $\mathrm{C} 1$ & $\mathrm{C} 2$ & C3 \\
\hline 3 & 3 & 3 & 3 & 2 & 2 & 2 & 3 & 3 & 2 & 2 & 3 & 3 & 3 \\
\hline
\end{tabular}

São Paulo), DSP (Diário de São Paulo), JTd (Jornal da Tarde), ESP (O Estado de S. Paulo), FSP (Folha de S. Paulo), VEJ (Veja) e EPC (Época).

85 Foi utilizado o título principal da reportagem para fins de identificação, mas a análise considerou todos os seus componentes.

86 Um exemplo simples dessa variação é a categoria de Cidades (CID), utilizada para o noticiário diário da região. O jornal Agora São Paulo tem a editoria "S. Paulo”; o Diário de São Paulo adotou "São Paulo" e "Dia a dia”; o Jornal da Tarde traz "Cidade”, o Estado de S. Paulo usa "Cidades” e a Folha de S. Paulo tem o caderno "Cotidiano".

A classificação nem sempre seguiu a editoria original - reportagens sobre crime em qualquer uma dessas editorias foi classificada como Polícia (PLC). 

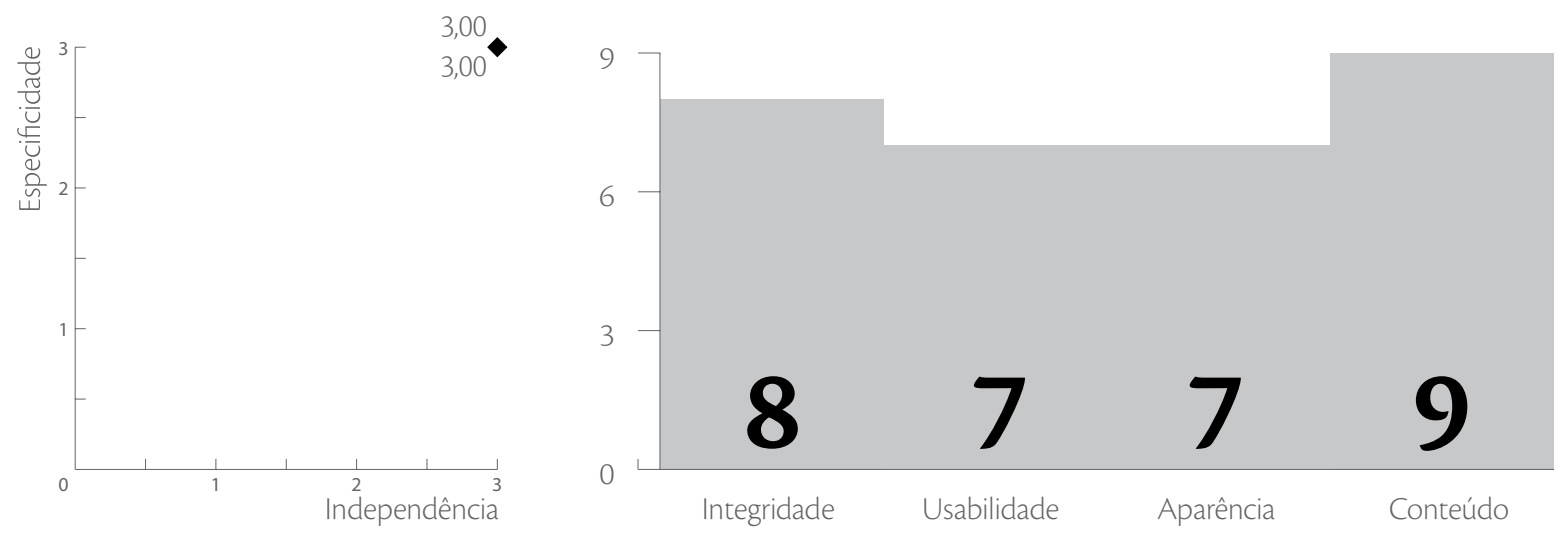

\subsubsection{Hipóteses}

Algumas expectativas foram levantadas considerando os objetos selecionados, antes da realização da análise de conteúdo. Essas hipóteses foram produzidas de acordo com o conhecimento obtido em pesquisa anterior sobre conceitos de jornalismo, design da informação e infográficos.

a) Índice de independência é moderado (abaixo de 2 pontos)

Jornais diários e revistas semanais, que compõem o corpo da pesquisa, são veículos de caráter mais conservador e que valorizam sua confiabilidade. $\mathrm{O}$ formato mais convencional, do texto verbal, deve ser predominante, fazendo do infográfico um complemento ou um recurso de menor importância.

b) Índice de especificidade é mais significativo (por volta de 2 pontos)

Embora reportagens infográficas não sejam comuns nos veículos analisados, a preocupação com novidade e atualidade - valores de noticiabilidade no jornalismo - sugere que a produção de infográficos se distancie de conhecimentos enciclopédicos.

c) Pontuação de integridade é alta (acima de 7 pontos)

De acordo com Crowell (1969, p. 19, tradução nossa),

Jornalismo é a coleta e edição de material de interesse atual para apresentação por meio dos meios de comunicação de massa. A função de um jornal é descobrir o que está acontecendo e transformar isso em palavras. Editores supervisionam o trabalho dos repórteres para garantirem que ele seja compreensível, de bom gosto, que não deixe perguntas sem resposta, e que não seja difamatório.

Percebe-se, assim, a preocupação com precisão e clareza, valores do fazer e do estilo jornalísticos. Como o infográfico é uma ferramenta de visualização do jornalismo, é de se esperar que seus dados sejam confiáveis, sua representação seja correta e a apresentação favoreça a compreensão. 
d) Componentes de visualidade e comunicação visual (A2 e C2) são mais fracos (1-2 pontos), mas a aparência (A1 e A3) recebe mais cuidados (2-3 pontos)

A origem dos infográficos é costumeiramente localizada no início do século 19 - e protoinfográficos foram encontrados em jornais do século anterior. No entanto, notou-se pouca evolução no formato desde então. Cairo (2008, p. 29) considera que os infográficos estetizantes são ainda predominantes; Holmes (Errea, 2004, p. 6) tampouco reconhece uma evolução comunicativa na ferramenta. Por isso, espera-se que a preocupação estética se destine mais à captura de atenção do que ao aprofundamento da análise.

e) Seleção de dados (C1) é adequada (2-3 pontos), mas contexto (C3) deixa a desejar (1-2)

De acordo com avaliação de Cairo (2008, p. 29) de que a infografia estetizante é predominante, pressupõe-se menor preocupação com componentes explicativos e analíticos. Já a identificação de pontos centrais de uma reportagem é tarefa simples, exposta na própria estrutura do texto jornalístico. Por isso, sua seleção não deve causar problemas.

f) Usabilidade é simples, limitando sua pontuação (5-7 pontos)

Ainda considerando o baixo valor analítico esperado e seleção simples de conteúdo, uma consequência possível é a baixa complexidade do resultado final. Assim, a leitura seria simples, mas sem a necessidade de hierarquizar a informação ou agrupar dados em níveis.

g) Complexidade de conteúdo e aparência (C2 e A3) é maior em revistas que em jornais

O auto-retrato do designer da informação feito por Holmes (Heller, 2006) prescreve a necessidade de "uma cadeira confortável para longas horas" de trabalho. Isso indica que a elaboração de um infográfico não apenas requer dedicação e especialização, mas também beneficia de prazos mais longos. Os jornais e as revistas analisados fazem noticiário geral, mas diferem em periodicidade - os primeiros são diários, os últimos são semanais. Por isso, faz sentido que os infográficos das revistas mostrem conteúdo mais aprofundado e produções mais detalhadas.

h) Infográficos da editoria de Ciência e Tecnologia oferecem resultados melhores

A ilustração científica é uma forma de design da informação própria da comunicação acadêmica, com forte parentesco com os infográficos dos jornais. No Brasil, revistas de popularização científica ${ }^{87}$ se tornaram conhecidas e foram premiadas com seus trabalhos de infografia ${ }^{88}$. Essa tradição significa mais tempo de desenvolvimento nesse gênero.

i) Os veículos Folha de S. Paulo e Época apresentam desempenhos superiores

87 A expressão "popularização científica" foi utilizada para caracterizar revistas voltadas a públicos gerais e de abrangência mais ampla (que inclui temas como religião e cultura pop).

88 Teixeira (2007, p. 113) verificou que a revista Superinteressante utiliza infográficos mais elaborados desde 1994 e que seus profissionais influenciaram outras publicações. 
O uso de infográficos no jornal Folha de S. Paulo é reconhecido como pioneiro no Brasil ${ }^{89}$ (Teixeira, 2009, p. 8) e já recebeu análises como a de Pereira (2006). A revista Época também vem enfatizando essa área e reforçou sua equipe com Alberto Cairo, profissional e estudioso da área. Em 2010, o jornal Folha de S. Paulo recebeu uma medalha de prata e duas de bronze no Malofiej, uma das mais importantes premiações internacionais de infografia. Nesse mesmo ano, a Época também foi premiada por uma peça infográfica digital. Esses fatos sugerem superioridade em seu conjunto de infográficos.

\subsubsection{Representação visual ${ }^{90}$ do processo de análise de conteúdo}

Teoria e lógica

\section{Decisões \\ conceituais \\ Medidas de \\ operalização}

Amostragem

\section{Treinamento e confiabilidade}

Codificação

Tabulação
Estudos indicando os efeitos de elementos diagramáticos, com aspectos verbais e visuais (Meyer, 1997; Poynter, 2007), indicam a necessidade de se estudar o uso de infográficos.

Além disso, muito se critica a evolução pouco significativa desde os primeiros exemplos aos dias atuais - reforçada pela percepção de Cairo (2008) de que a produção de infográficos enfatiza seu valor estético, e não analítico. É, portanto, interessante avaliar se essas observações

$\checkmark$ correspondem à realidade.

Cada reportagem tem seu componente infográfico caracterizado de acordo com critérios detalhados no guia de análise.

O guia de análise segue modelo de caracterização proposto neste trabalho. O formulário, de acordo com o guia, foi apresentado e define representações gráficas dos dados coletados.

A amostragem inclui infográficos (dentro das especificações apresentadas) encontrados em cinco títulos de jornais diários e duas revistas semanais. O conjunto reúne noticiário de interesse geral. $\mathrm{O}$ uso de três grupos $\checkmark$ espaçados em seis meses ajuda a formar panorama mais representativo. O método de caracterização que compõe o guia foi testado e depurado em pré-testes. A delimitação mais clara da pontuação melhorou a qualidade do método e a confiabilidade dos resultados.

Análise com apenas um decodificador. Repetição em períodos diferentes verificou baixo índice de variação.

Dados coletados podem ser combinados por veículos, por categoria, por grupos e por tipo de publicação, com representação gráfica de resultados.

89 Ao lado dos jornais O Dia e O Globo e de revistas da editora Abril, como Superinteressante e Saúde!. 90 Inspirado em "A flowchart for the typical process of content analysis research" (Neuendorf, 2002, p. 50-51). 


\subsection{Resultados}

O formulário gera representações gráficas para os resultados da análise de conteúdo ${ }^{91}$, facilitando a interpretação dos resultados. Os gráficos abaixo representam a média de pontuação ${ }^{92}$ do conjunto de infográficos de cada edição analisada.
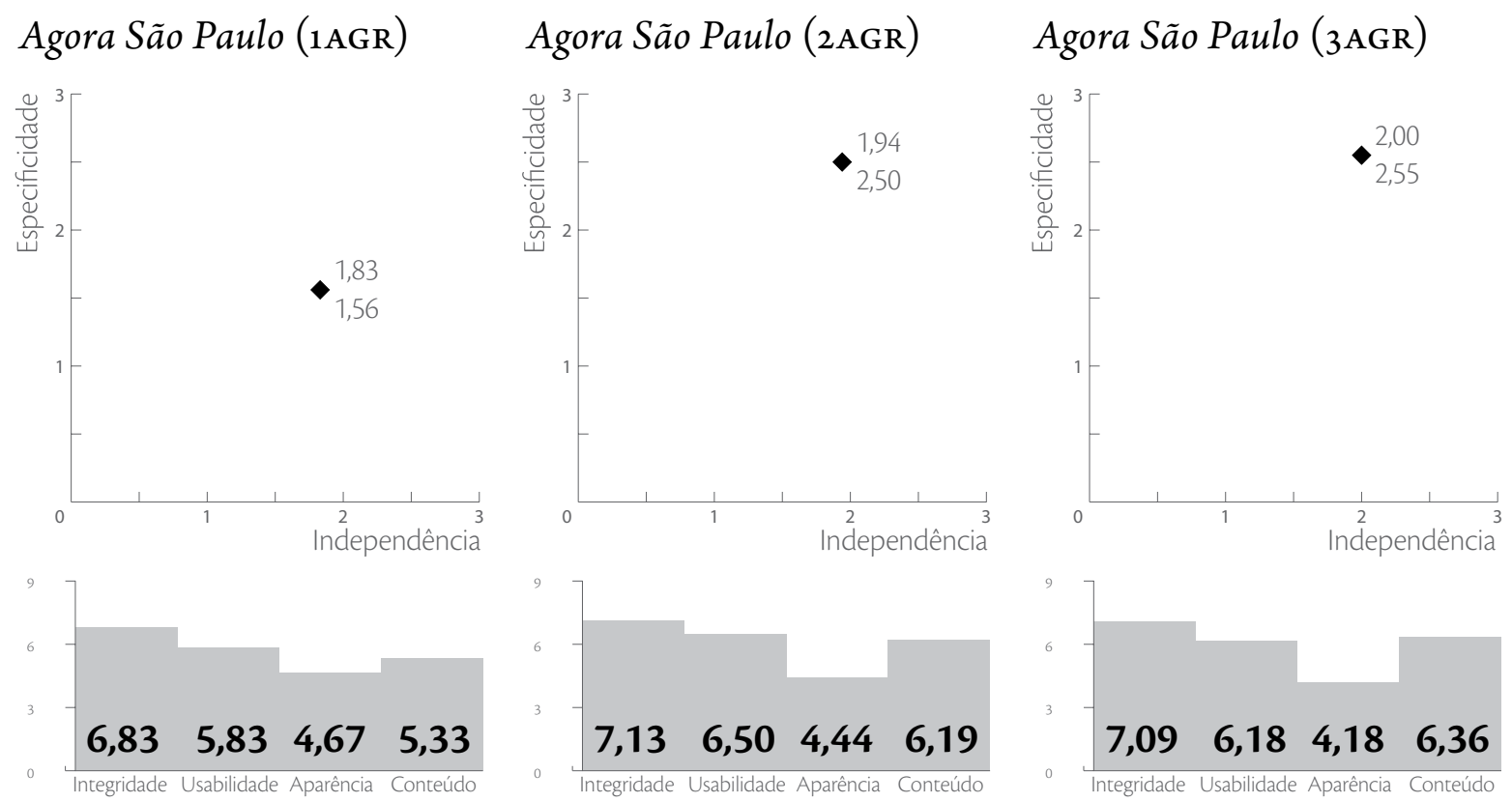

Diário de São Paulo (1DSP)
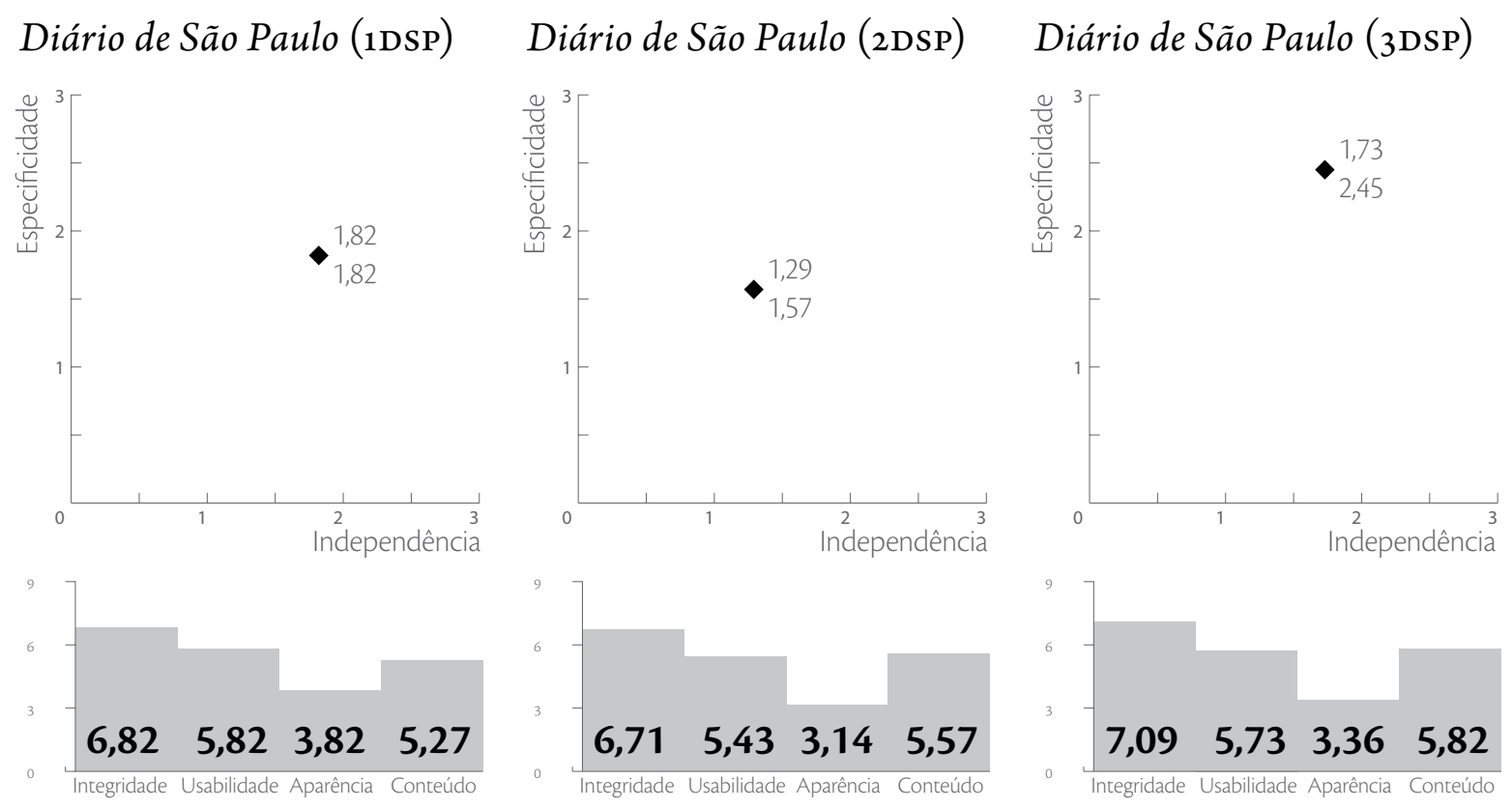

91 Resultados detalhados e tabulados estão incluídos no Apêndice.

92 Para normalizar os valores e permitir comparação, a pontuação de cada item em cada edição foi somada e dividida pelo número de peças. 
O Estado de S. Paulo (1ESP)
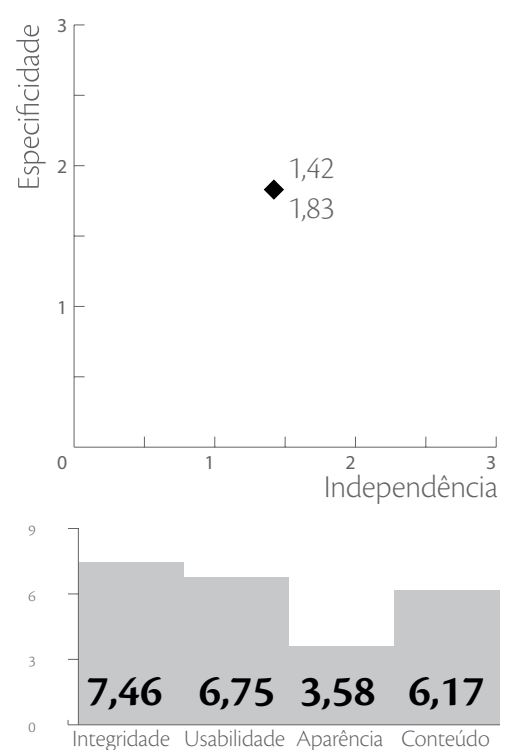

Folha de S. Paulo (1FSP)

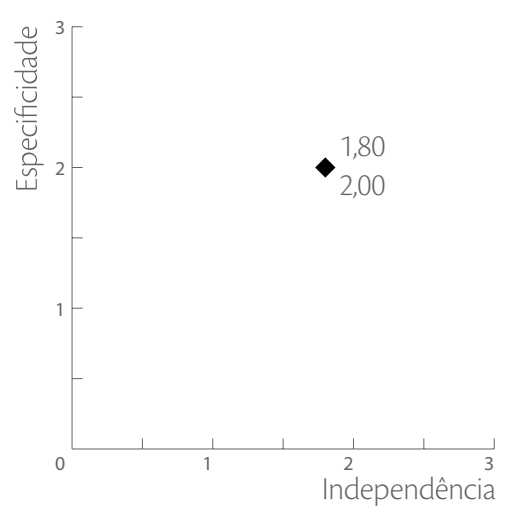

$\begin{array}{llll}7,20 & 6,00 & 4,07 & 5,80\end{array}$
O Estado de S. Paulo (2ESP)
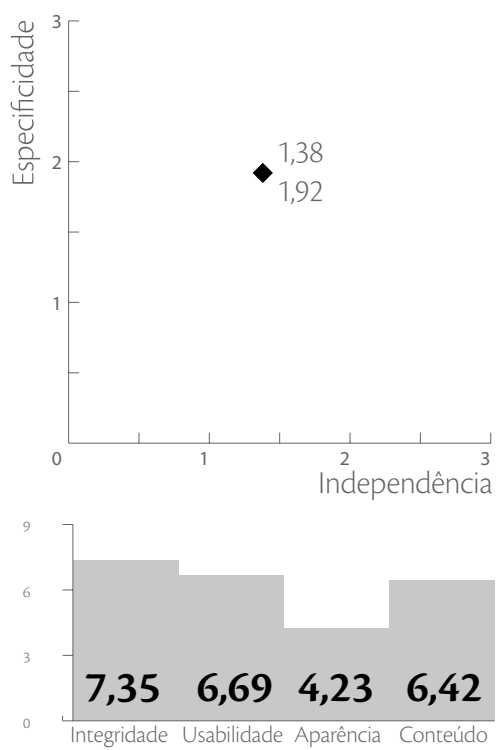

Folha de S. Paulo (2FSP)
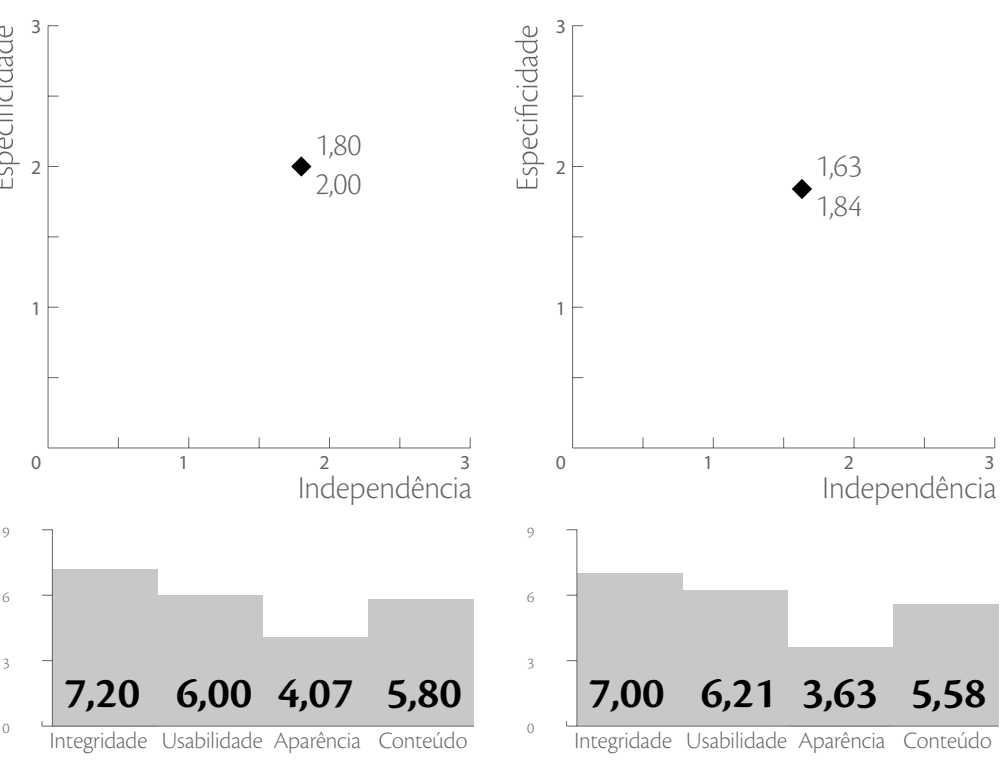

O Estado de S. Paulo (3ESP)
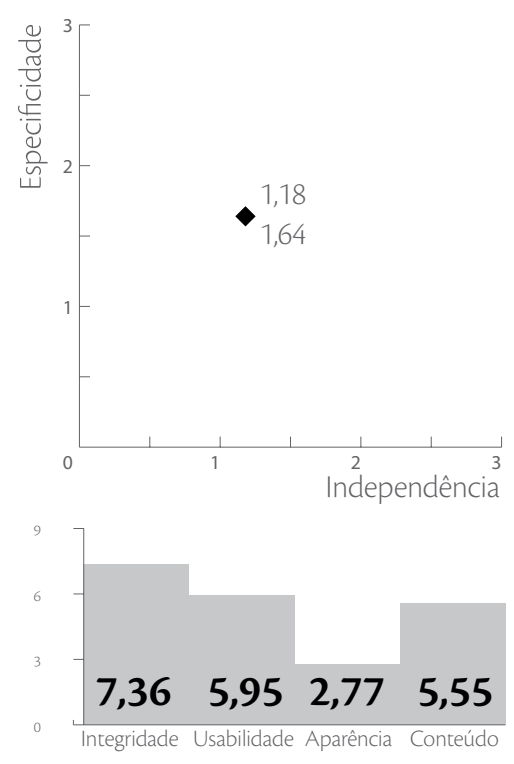

Folha de S. Paulo (3FSP)

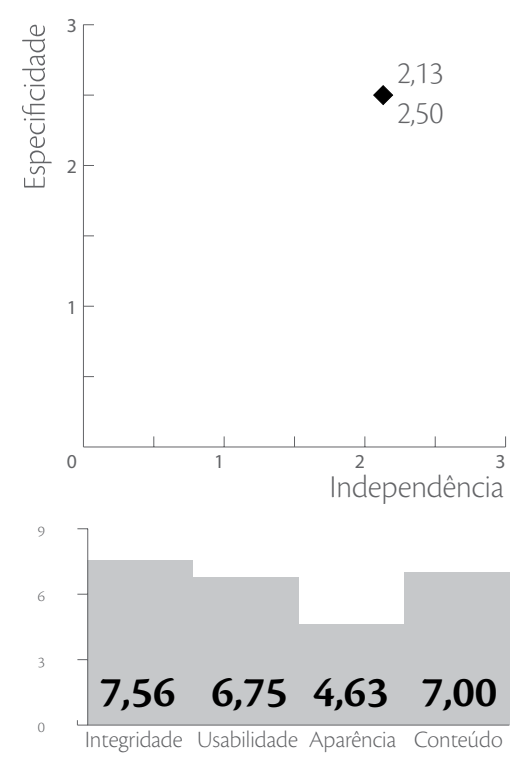



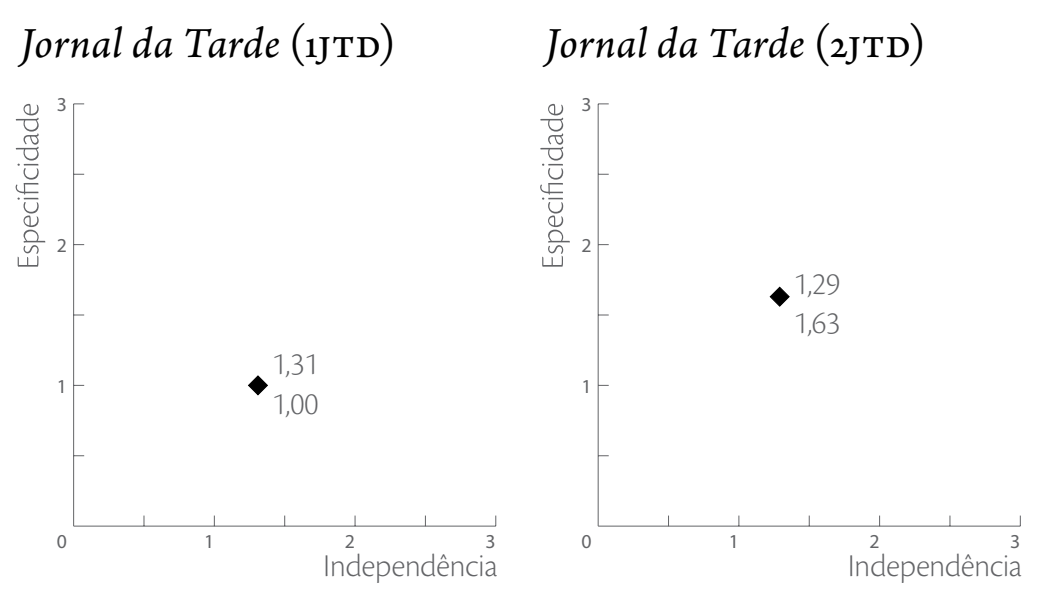

Jornal da Tarde (3JTD)
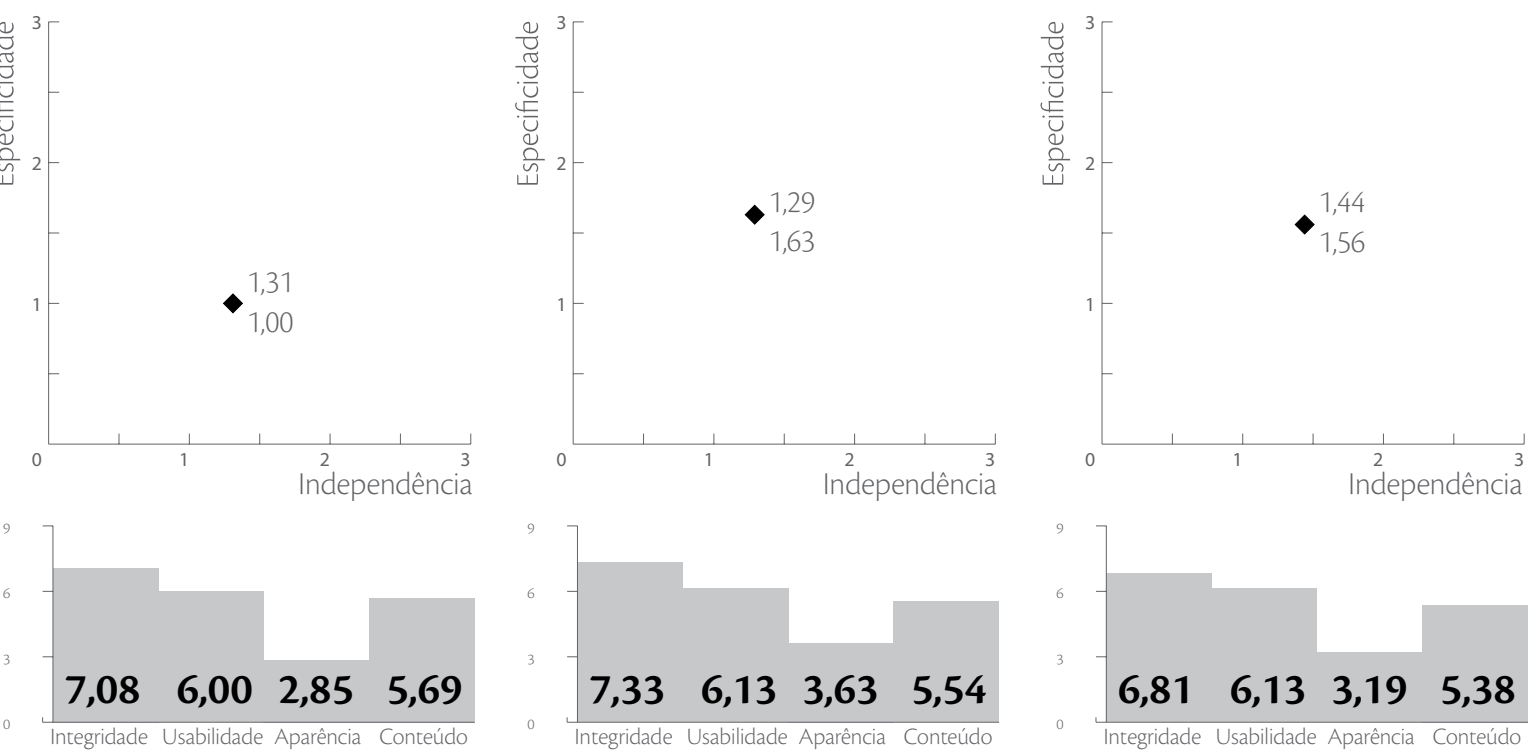

Época (1EPC)

Época (2EPC)

Época (3EPC)
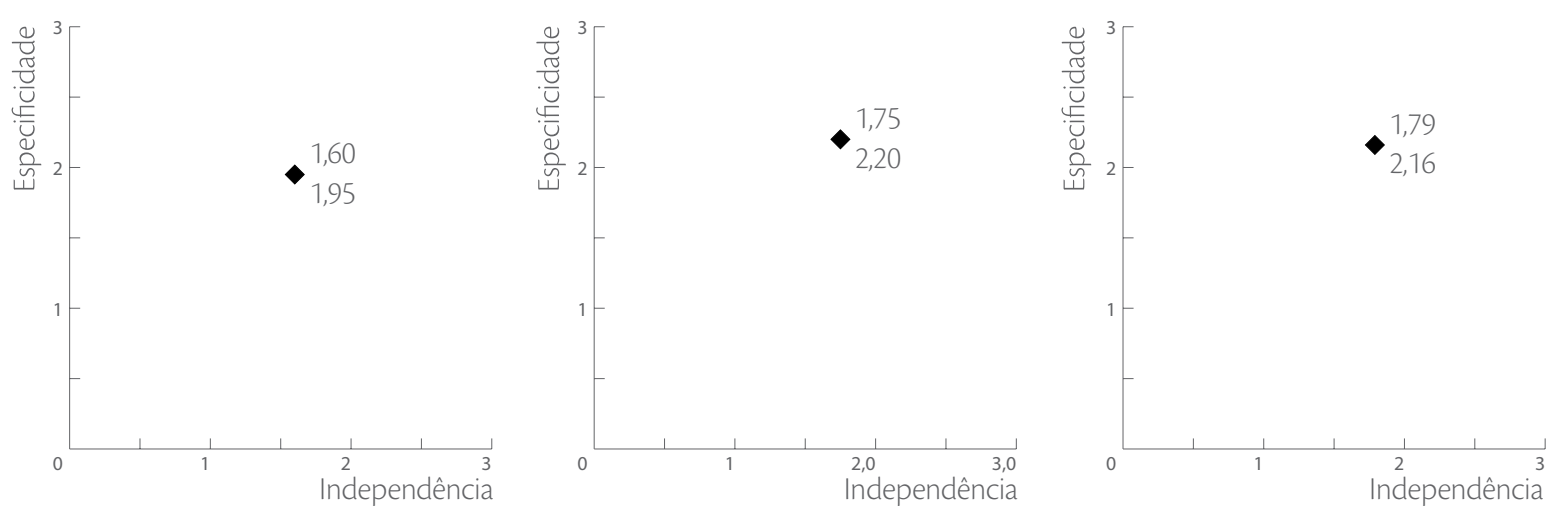

$\begin{array}{llll}7,70 & 6,45 & 4,65 & 5,80\end{array}$ 

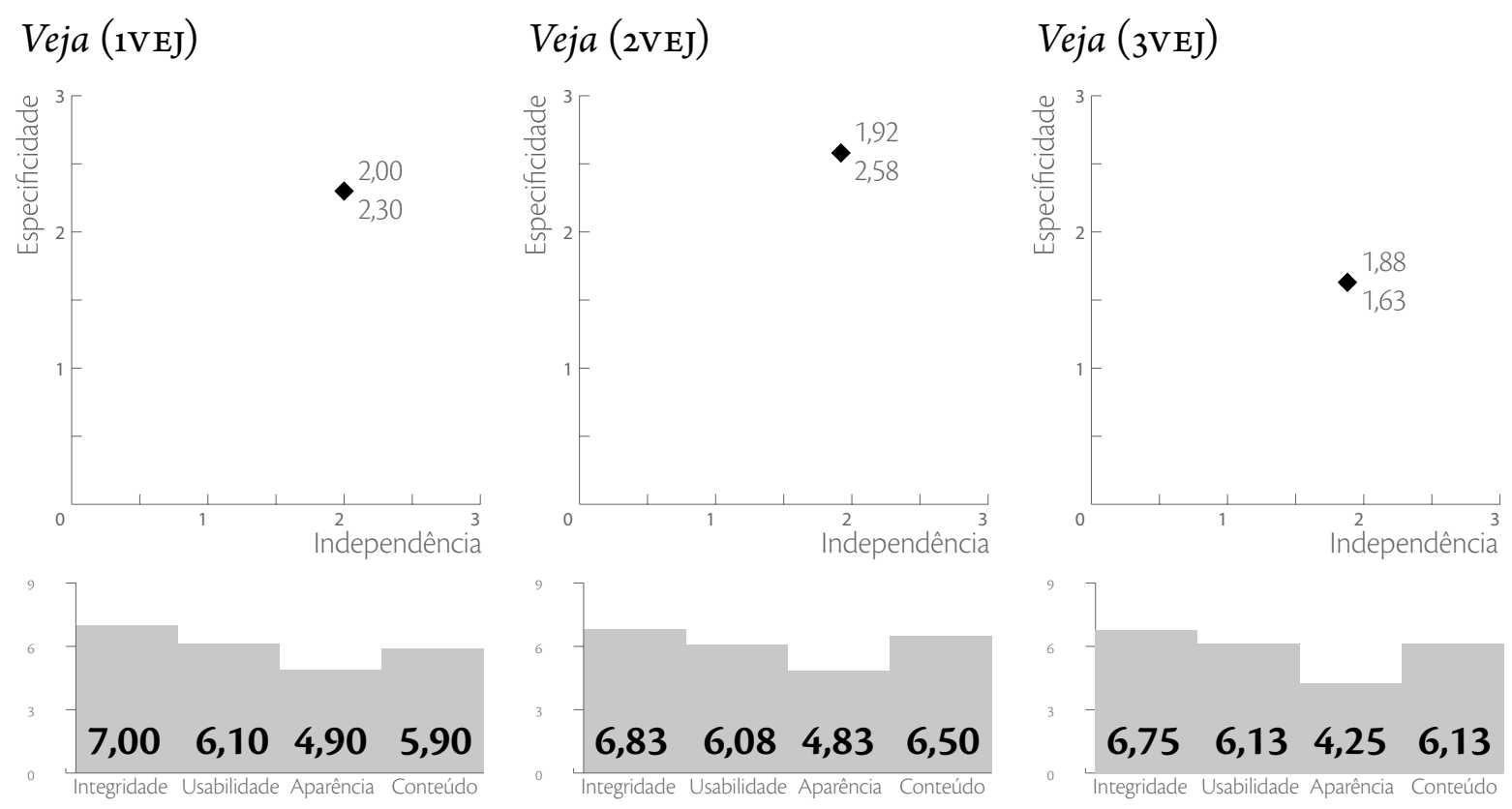

\subsubsection{Eixos subordinado-independente e enciclopédico-específico}

O índice médio de independência ficou em 1,63 - consideravelmente abaixo dos 2 pontos $^{93}$. Isso indica não apenas os veículos analisados raramente utilizam reportagens infográficas, mas que muitas peças têm importância reduzida.

O índice de especificidade teve média de 1,94 (valor bastante próximo a 2 pontos $^{94}$ ). Entende-se que há preocupação noticiosa - mas inconstante, alternada a peças padronizadas.

\begin{tabular}{l|r|r|r|r} 
& Índice de independência & & Índice de especificidade & \multicolumn{2}{|c}{ Peças } \\
\hline AGR & 1,91 & 2,13 & 45 \\
\hline DSP & 1,66 & 2,00 & 29 \\
\hline ESP & 1,34 & 1,81 & 72 \\
\hline FSP & 1,84 & 2,10 & 50 \\
\hline JTD & 1,34 & 1,45 & 53 \\
\hline JORNAIS & 1,58 & 1,87 & 249 \\
\hline EPC & 1,71 & 2,10 & 59 \\
\hline VEJ & 1,93 & 2,23 & 30 \\
\hline REVISTAS & 1,79 & 2,15 & 89 \\
\hline MÉDIA & $\mathbf{1 , 6 3}$ & $\mathbf{1 , 9 4}$ & $\mathbf{3 3 8}$
\end{tabular}

93 Nesse eixo, 2 pontos são conferidos quando há equilíbrio de importância entre os elementos da reportagem. 94 No segundo eixo, 2 pontos indicam relação elástica com fato noticiado. 
a) Jornais e revistas

O gráfico abaixo compara jornais e revistas em índice de independência (x) e especificidade (Y). A área de cada círculo representa o total de peças analisadas em cada tipo de veículo.

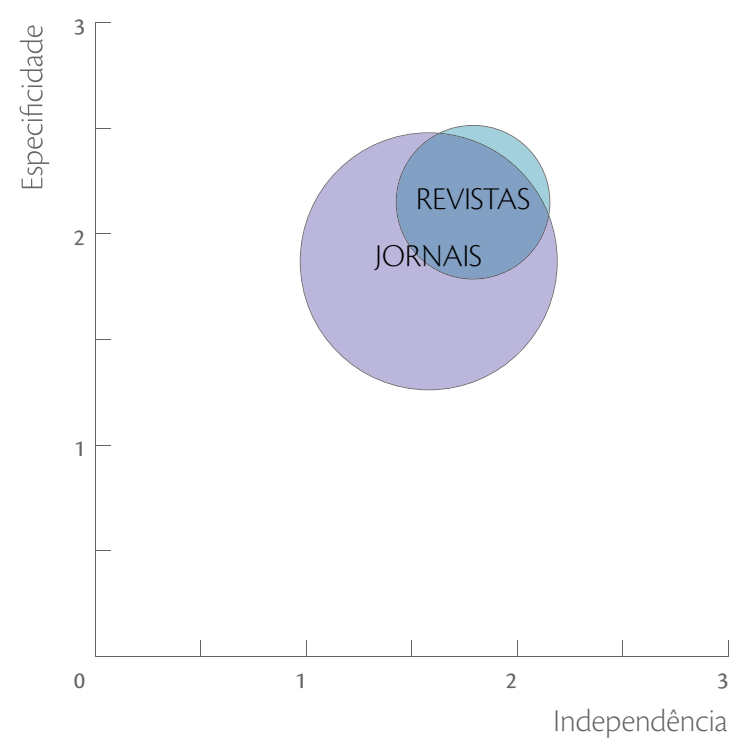

Verificou-se certa variação na média dos índices de independência e de especificidade, em favor de revistas. Semanais, elas têm período de produção maior do que os jornais diários. Como consequência, coberturas noticiadas ao longo de vários dias em jornais diários são reunidas em textos únicos das revistas semanais. Essas duas características favorecem a produção de infográficos mais específicos às reportagens das revistas.

A periodicidade também implica em vida útil mais longa para as revistas, gerando mais preocupações estéticas (que se estendem até mesmo ao tipo de papel, que não amarela na mesma velocidade). Revistas são veículos mais visuais, utilizando elementos como fotografias, ilustrações e infográficos de forma mais enfática.

b) Jornais

Os títulos Agora São Paulo e Folha de S. Paulo, pertencentes ao mesmo grupo editorial, mostram semelhança nos índices de independência e especificidade. Verificou-se entre essas duas publicações o compartilhamento de infográficos prontos $^{95}$ ou de dados (adaptados com algumas diferenças).

O Estado de S. Paulo e Jornal da Tarde, em situação similar, têm menos proximidade, embora também compartilhem certos materiais ${ }^{96}$. No conjunto, o Jornal da Tarde ficou significativamente abaixo do desempenho d'O Estado e da média dos jornais nos dois eixos. Um

95 Alguns exemplos são o mapa de revitalização do centro da cidade de São Paulo (1AGRoo2 e 1FSPOo8) e a rota de entrada de armas no país (2AGRo11 e 2FSPOO9).

96 O suplemento estadão.EDU (sobre vestibular) é encartado também no Jornal da Tarde, com o nome jt.EDU. 
fator para essa diferença é a grande quantidade de infográficos na editoria de Esportes - 13 das 53 peças analisadas pertencem a essa categoria $(24,52 \%)$-, que é caracterizada pelo uso de formatos padronizados e de importância reduzida, como escores ${ }^{97}$ e sumários de jogos.

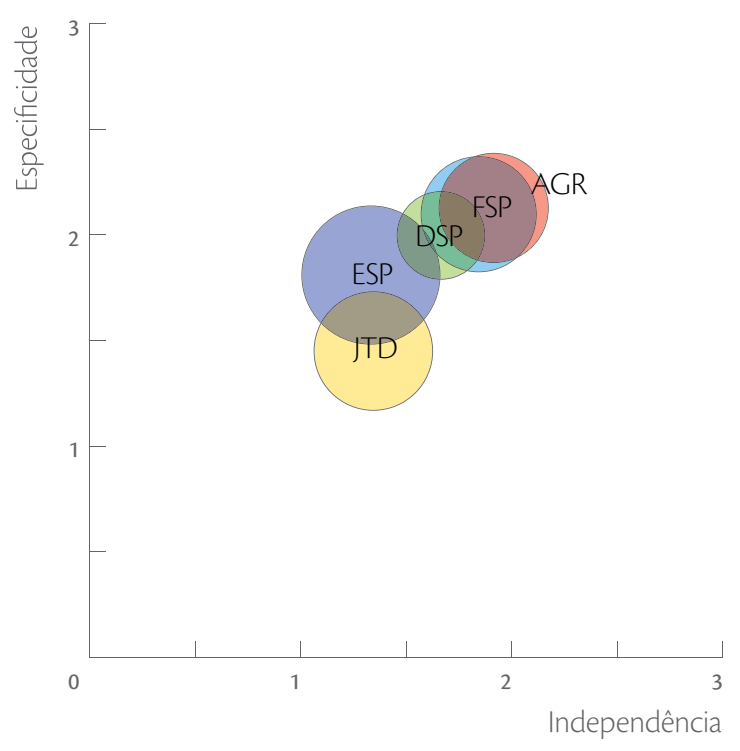

c) Revistas

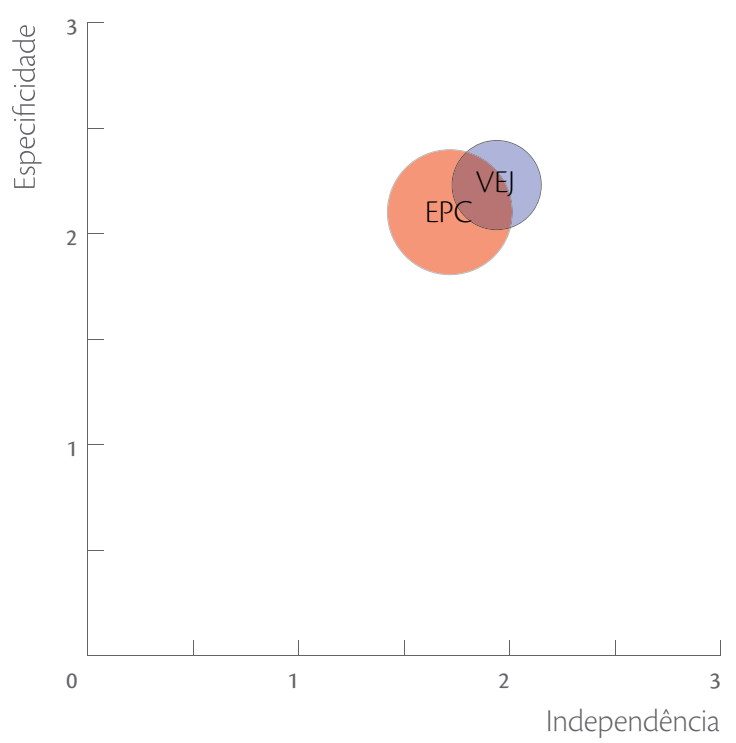

A revista Veja apresentou índices superiores de independência e especificidade em relação à Época. Um fator que contribuiu para essa diferença foi o uso padronizado de infográficos em seções da Época (que é reforçado pela maior quantidade de peças encontradas nessa publicação).

97 O termo "escores" é aqui usado no sentido do jornalismo visual (destaques dados a valores numéricos), e não significando resultado de eventos esportivos. 
Um dos formatos é um perfil, na forma de sumário, identificando personalidades entrevistadas. Esse tipo de infográfico recebe pontuações inferiores de especificidade, porque se trata de um formato fixo, e também de independência, por receber baixa ênfase visual e espacial.

Removendo-se esse tipo de infográfico do conjunto analisado, percebeu-se maior proximidade entre os índices das duas publicações:

\begin{tabular}{l|r|rr|r} 
& Índice de independência & & Índice de especificidade & \multicolumn{2}{|c}{ Peças } \\
\hline EPC & 1,71 & 2,10 & 59 \\
\hline EPC $^{*}$ & 1,86 & 2,33 & 49 \\
\hline VEJ & 1,93 & 2,23 & 30 \\
\hline
\end{tabular}

* O segundo conjunto da revista Época exclui da análise os perfis de entrevistados.

\subsubsection{Eixos estetixante-analítico}

Todos os veículos analisados apresentam comportamento similar na relação entre os quatro elementos do eixo estetizante-analítico: índices mais altos de integridade, seguidos por posição de equilíbrio entre usabilidade e conteúdo ${ }^{98}$, e índices mais baixos de aparência.

\begin{tabular}{l|r|r|r|r|r} 
& Integridade & Usabilidade & Aparência & Conteúdo & Peças \\
\hline AGR & 7,00 & 6,16 & 4,47 & 5,89 & 45 \\
\hline DSP & 6,90 & 5,69 & 3,48 & 5,55 & 29 \\
\hline ESP & 7,39 & 6,49 & 3,57 & 6,07 & 72 \\
\hline FSP & 7,24 & 6,32 & 4,08 & 6,10 & 50 \\
\hline JTD & 7,11 & 6,09 & 3,30 & 5,53 & 53 \\
\hline JORNAIS & 7,17 & 6,22 & 3,77 & 5,87 & 249 \\
\hline EPC & 7,56 & 6,61 & 4,53 & 6,02 & 59 \\
\hline VEJ & 6,87 & 6,10 & 4,70 & 6,20 & 30 \\
\hline REVISTAS & 7,33 & 6,44 & 4,58 & 6,08 & 89 \\
\hline MÉDIA & 7,21 & $\mathbf{6 , 2 8}$ & 3,98 & $\mathbf{5 , 9 2}$ & 338
\end{tabular}

a) Jornais e revistas

Nos gráficos a seguir, a porção enfatizada da barra representa valores superiores aos índices médios gerais. 
Jornais

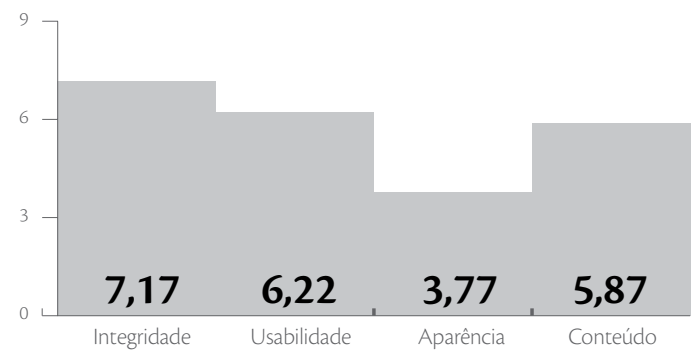

Revistas

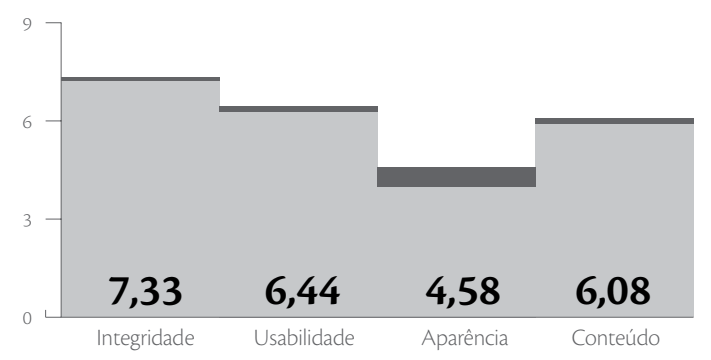

Os índices médios encontrados nas duas revistas analisadas foram superiores aos índices médios obtidos na análise dos cinco jornais. A diferença mais significativo ocorreu no elemento de aparência, refletindo maior preocupação estética desse tipo de publicação.

b) Jornais

Os gráficos representam os índices médios de cada publicação. As seções destacadas trazem valores acima do índice médio dos jornais.

Agora São Paulo

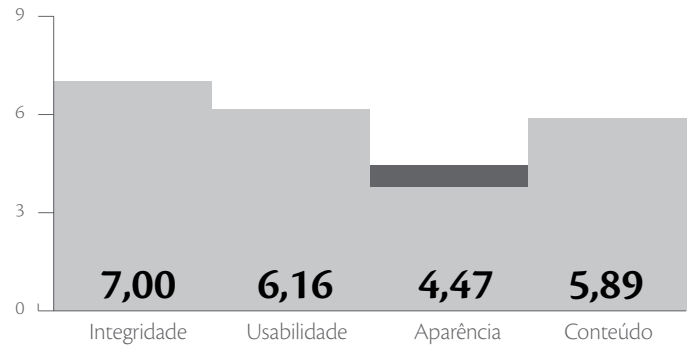

O Estado de S. Paulo

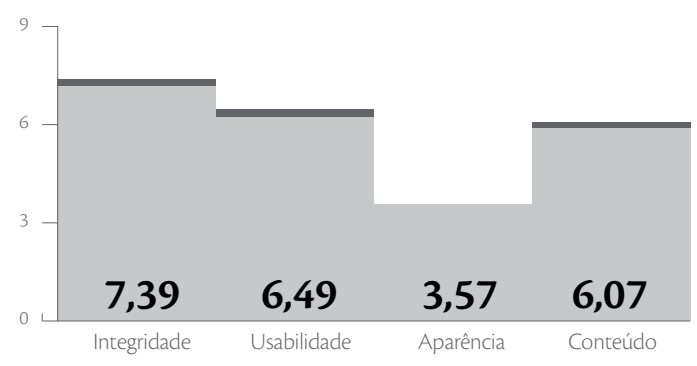

Jornal da Tarde

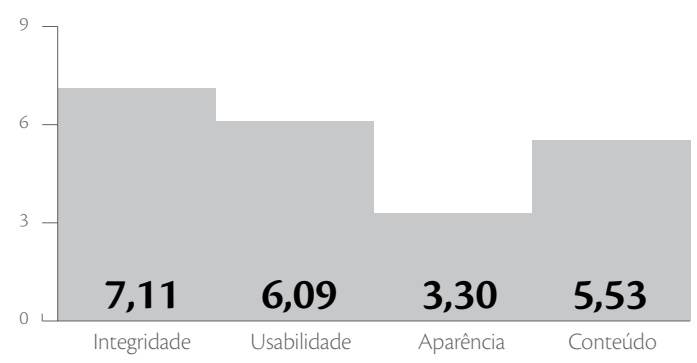

Diário de São Paulo

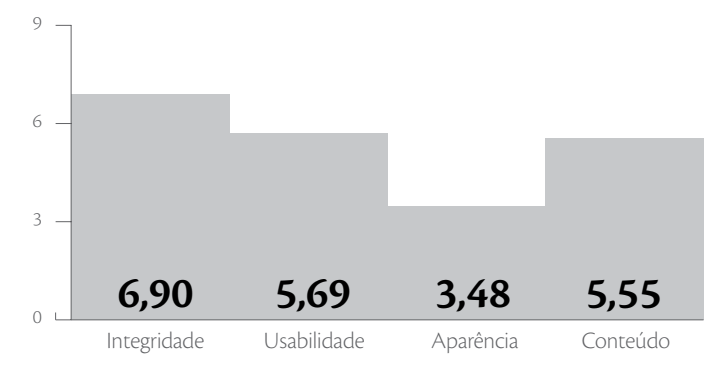

Folha de S. Paulo

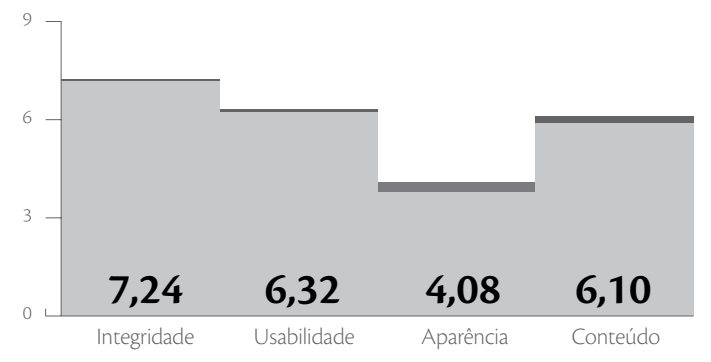


Todos os jornais apresentam o mesmo perfil: índice razoável de integridade, índices similares de usabilidade e conteúdo e índices baixos de aparência. Neste conjunto também se observam:

- Agora e Folha - as duas publicações do mesmo grupo apresentaram os melhores índices de aparência. O Agora, de caráter mais popular, é o que apresenta maior preocupação visual.

- Estado - o jornal teve índices significativamente acima da média em integridade, usabilidade e conteúdo. Nos dois primeiros, a média d'O Estado foi a mais alta entre os jornais diários.

- Jornal da Tarde e Diário - as duas publicações registraram os índices mais baixos do conjunto. O Diário, no entanto, mostrou mais problemas de integridade e usabilidade, além de ter a menor quantidade de infográficos publicados nos três dias selecionados.

c) Revistas

Os gráficos representam os índices médios de cada publicação. As seções destacadas trazem valores acima do índice médio das revistas. Novamente, os perfis são bastante parecidos.
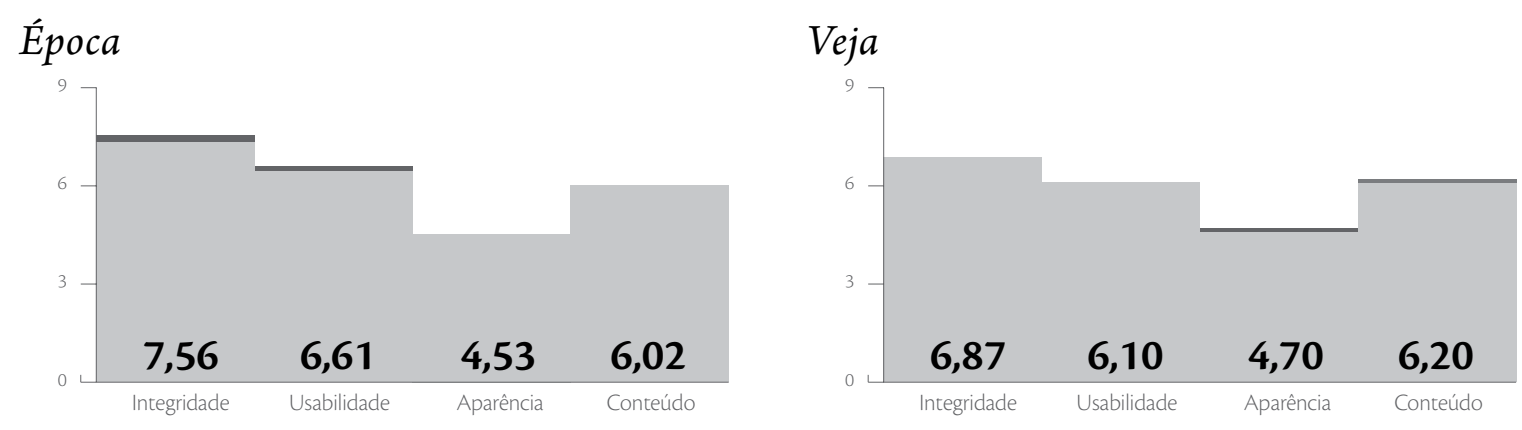

A revista Veja apresentou índice médio inferior a 7 pontos em integridade. Assim como o jornal Diário de São Paulo, a publicação faz uso limitado de infográficos, menos frequentes em suas páginas que no veículo concorrente.

Já a análise da Época registrou baixo valor de aparência, apesar do uso mais comum de infográficos. Mais uma vez, formatos padronizados influenciaram negativamente a avaliação do veículo. Removendo-se os perfis sumarizados que acompanham entrevistas, o conjunto da revista obteve grande melhora nos índices de aparência e variação significativa no índice de conteúdo.

\begin{tabular}{l|r|r|r|r|r|r|} 
& Integridade & Usabilidade & Aparência & Conteúdo & \multicolumn{2}{|c}{ Peças } \\
\hline EPC & 7,56 & 6,61 & 4,53 & 6,02 & 59 \\
\hline EPC $^{*}$ & 7,47 & 6,53 & 5,04 & 6,22 & 49 \\
\hline VEJ & 6,87 & 6,10 & 4,70 & 6,20 & 30 \\
\hline
\end{tabular}

* O segundo conjunto da revista Época exclui da análise os perfis de entrevistados. 
d) Análise detalhada de elementos

Os contornos de todas as publicações avaliadas são bastante similares, permitindo indicar tendências gerais para cada um dos elementos analisados.

Agora

São Paulo

\begin{tabular}{cccccccccccc}
$\mathbf{2 , 4 9}$ & $\mathbf{2 , 5 6}$ & $\mathbf{1 , 9 6}$ & $\mathbf{2 , 0 7}$ & $\mathbf{2 , 0 4}$ & $\mathbf{2 , 0 4}$ & $\mathbf{1 , 7 3}$ & $\mathbf{1 , 5 6}$ & $\mathbf{1 , 1 8}$ & $\mathbf{2 , 4 7}$ & $\mathbf{1 , 4 9}$ & $\mathbf{1 , 9 3}$ \\
\hline 11 & 12 & 13 & $U 1$ & $\mathrm{U} 2$ & $\mathrm{U} 3$ & $\mathrm{~A} 1$ & $\mathrm{~A} 2$ & $\mathrm{~A} 3$ & $\mathrm{C} 1$ & $\mathrm{C} 2$ & $\mathrm{C} 3$
\end{tabular}

Diário de

São Paulo

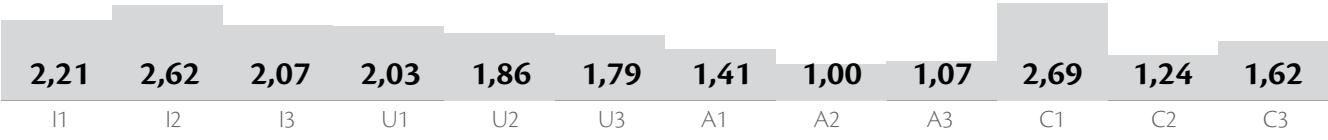

O Estado

de S. Paulo

\begin{tabular}{|c|c|c|c|c|c|c|c|c|c|c|c|}
\hline 2,43 & 2,65 & 2,31 & 2,10 & 2,24 & 2,15 & 1,39 & 0,93 & 1,25 & 2,46 & 1,75 & 1,86 \\
\hline 11 & 12 & 13 & U1 & U2 & U3 & A1 & A2 & A3 & C1 & C2 & C3 \\
\hline
\end{tabular}

Folha

de S. Paulo

$\begin{array}{llllllllllll}2,40 & 2,58 & 2,26 & 2,00 & 2,24 & 2,08 & 1,64 & 1,18 & 1,26 & 2,60 & 1,72 & 1,78\end{array}$

Jornal da

Tarde

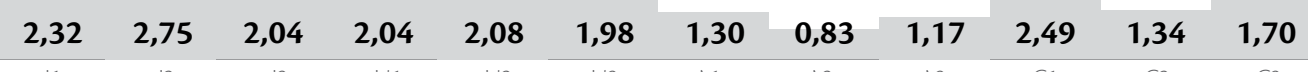

Jornais

$\begin{array}{cccccccccccc}\mathbf{2 , 3 9} & \mathbf{2 , 6 4} & \mathbf{2 , 1 5} & \mathbf{2 , 0 5} & \mathbf{2 , 1 2} & \mathbf{2 , 0 4} & \mathbf{1 , 4 9} & \mathbf{1 , 0 8} & \mathbf{1 , 2 0} & \mathbf{2 , 5 2} & \mathbf{1 , 5 5} & \mathbf{1 , 8 0} \\ 11 & 12 & 13 & U 1 & \text { U2 } & \text { U3 } & \text { A } 1 & \text { A2 } & \text { A3 } & \text { C1 } & \text { C2 } & \text { C3 }\end{array}$

Época

\begin{tabular}{cccccccccccc}
$\mathbf{2 , 5 4}$ & $\mathbf{2 , 7 1}$ & $\mathbf{2 , 3 1}$ & $\mathbf{2 , 1 5}$ & $\mathbf{2 , 1 9}$ & $\mathbf{2 , 2 7}$ & $\mathbf{1 , 6 9}$ & $\mathbf{1 , 4 9}$ & $\mathbf{1 , 3 4}$ & $\mathbf{2 , 4 6}$ & $\mathbf{1 , 6 4}$ & $\mathbf{1 , 9 2}$ \\
\hline 11 & 12 & 13 & $U 1$ & $U 2$ & $U 3$ & $A 1$ & $A 2$ & $A 3$ & $C 1$ & $C 2$ & $C 3$
\end{tabular}

Veja

$$
\begin{array}{llllllllllll}
2,33 & 2,57 & 1,97 & 2,00 & 2,03 & 2,07 & 1,73 & 1,60 & 1,37 & 2,50 & 1,57 & 2,13
\end{array}
$$

Revistas

$\begin{array}{llllllllllll}2,47 & 2,66 & 2,19 & 2,10 & 2,13 & 2,20 & 1,71 & 1,53 & 1,35 & 2,47 & 1,62 & 1,99\end{array}$

Média

geral 
- Integridade - as três subdivisões tiveram índices médios superiores a 2 pontos. Verificou-se algum problema de precisão (I1), principalmente nos jornais Diário de São Paulo e Jornal da Tarde. Um fator foi a falta de indicação sobre a origem dos dados, reduzindo a confiabilidade. Melhores índices foram obtidos na clareza (I2), indicando que a linguagem infográfica segue o estilo jornalístico. $\mathrm{Na}$ análise de escala (I3), observou-se grande frequência de infográficos que não faziam uso do recurso (e recebiam pontuação 2).

- Usabilidade - as três subdivisões receberam índices próximos (um pouco acima de 2 pontos). Não foram verificados problemas significativos de legibilidade e reconhecimento de traçado (U1), mas esse recurso foi pouco utilizado para hierarquizar a informação. A organização (U2) se mostrou adequada, mas também sem valor de hierarquização. $\mathrm{Na}$ escolha de formato (U3), verificou-se o uso de representações que favoreciam a organização, mas não reforçavam conexões ou interpretações.

- Aparência - o componente de atração do leitor (A1) foi o mais eficiente, mas apenas porque mesmo listas de itens têm efeito na leitura. A baixa pontuação da comunicação visual (A2) reflete o baixo uso de elementos figurativos e iconográficos, além do excesso de componentes genéricos. O valor estético (A3) também deixou a desejar, devido ao uso de formatos padronizados. Em todos os veículos analisados, encontrou-se grande quantidade de infográficos que se limitavam a quadros de textos.

- Conteúdo - a seleção de conteúdo (C1) obteve os melhores índices, mostrando que todos os veículos utilizam infográficos para enfatizar ou resumir pontos centrais. No entanto, a apresentação desses pontos faz uso baixo da visualidade (C2), como se percebeu na baixa pontuação da aparência dos infográficos. $\mathrm{O}$ aprofundamento e a contextualização da informação (C3) também são baixos, refletindo uso recorrente de sumários que apenas resumem as informações principais.

\subsubsection{Editorias}

Política, Economia, Cidades, Esportes e Entretenimento (cultura, diversão) foram selecionadas para análise por serem editorias comuns em diversos veículos jornalísticos, ainda que distribuídas sob rótulos diferentes. Já a editoria de Ciência e Tecnologia foi selecionada pela tradição no uso de infográficos e sua relação próxima com a ilustração científica. Além disso, as editorias correspondem a porção significativa ${ }^{99}$ do total de peças analisadas.

\begin{tabular}{l|r|r} 
& Peças & Porcentagem \\
\hline Política (POL) & 47 & $13,91 \%$ \\
\hline Economia (ECN) & 63 & $18,64 \%$ \\
\hline Cidades (CID) & 25 & $7,40 \%$
\end{tabular}

99 Outras seções encontradas tiveram menor ocorrência, como Polícia, Saúde e Dicas/Serviços, ou se relacionavam a suplementos, como Educação e Viagem/Turismo 


\begin{tabular}{l|r|r} 
& Peças & Porcentagem \\
\hline Ciência e Tecnologia (CET) & 16 & $4,73 \%$ \\
\hline Esportes (ESP) & 46 & $13,61 \%$ \\
\hline Entretenimento (ENT) & 37 & $10,95 \%$ \\
\hline & $\mathbf{2 3 4}$ & $\mathbf{6 9 , 2 3 \%}$
\end{tabular}
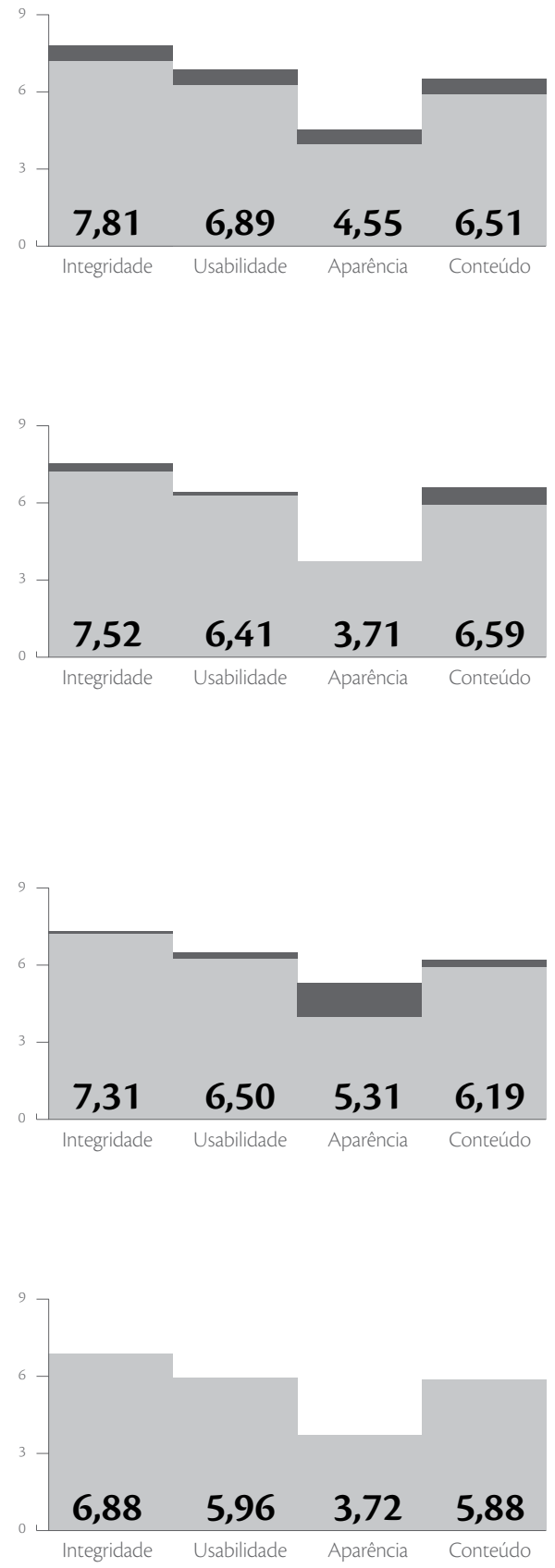

- Cidades - nas editorias que abrangem a cobertura
factual local, é comum encontrar reportagens que prio-
rizam a agilidade, e não a reflexão. Essa característica
levou a infográficos com índices inferiores à média em
todos os elementos. Verificou-se também grande ocor-
rência de sumários textuais com função de resumir e

- Cidades - nas editorias que abrangem a cobertura
factual local, é comum encontrar reportagens que prio-
rizam a agilidade, e não a reflexão. Essa característica
levou a infográficos com índices inferiores à média em
todos os elementos. Verificou-se também grande ocor-
rência de sumários textuais com função de resumir e

- Cidades - nas editorias que abrangem a cobertura
factual local, é comum encontrar reportagens que prio-
rizam a agilidade, e não a reflexão. Essa característica
levou a infográficos com índices inferiores à média em
todos os elementos. Verificou-se também grande ocor-
rência de sumários textuais com função de resumir e

- Cidades - nas editorias que abrangem a cobertura
factual local, é comum encontrar reportagens que prio-
rizam a agilidade, e não a reflexão. Essa característica
levou a infográficos com índices inferiores à média em
todos os elementos. Verificou-se também grande ocor-
rência de sumários textuais com função de resumir e

- Cidades - nas editorias que abrangem a cobertura
factual local, é comum encontrar reportagens que prio-
rizam a agilidade, e não a reflexão. Essa característica
levou a infográficos com índices inferiores à média em
todos os elementos. Verificou-se também grande ocor-
rência de sumários textuais com função de resumir e

- Cidades - nas editorias que abrangem a cobertura
factual local, é comum encontrar reportagens que prio-
rizam a agilidade, e não a reflexão. Essa característica
levou a infográficos com índices inferiores à média em
todos os elementos. Verificou-se também grande ocor-
rência de sumários textuais com função de resumir e simplificar os fatos.

- Política - a editoria apresentou índices acima da média em todos os elementos. Em parte, isso se deve a sua maior ocorrência nos veículos que apresentaram melhor desempenho, como Estado e Folha. Além disso, muitos infográficos políticos mostraram caráter didático ou explicativo, como a cobertura sobre as eleições na África do Sul (1FSPOo5).

- Economia - infográficos das editorias de economia destacavam informações quantitativas em contexto, melhorando o índice de avaliação de conteúdo. Além disso, havia maior ocorrência de citação de fonte dos dados (essencial para sua credibilidade no mercado), elevando também o índice de integridade. $\mathrm{O}$ uso frequente de gráficos quantitativos e estilo sóbrio, no entanto, foram refletidos em menor valor estético.

- Ciência e Tecnologia - assim como no caso de Política, a editoria registrou índices superiores à média em todos os elementos. A variação mais significativa foi encontrada na aparência - reforçando o vínculo com a ilustração científica e caráter didático, que puderam ser verificados em casos como explicação sobre doença de Chagas (1ESPOO7). 

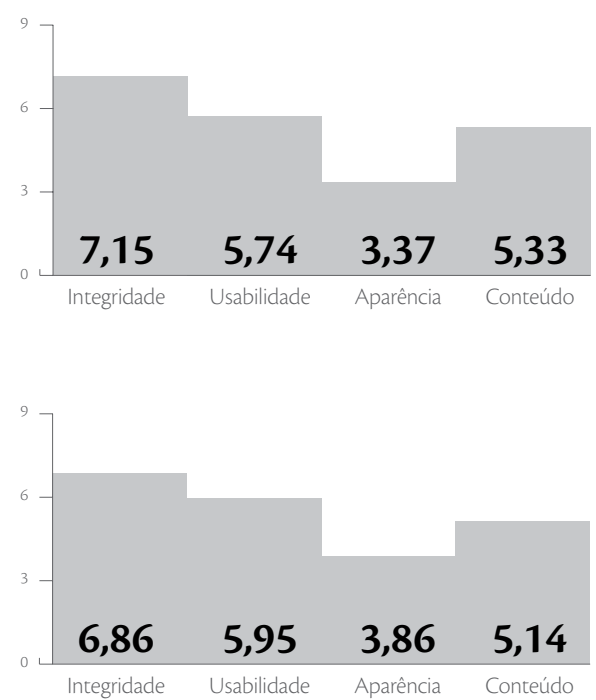

\subsubsection{Variação temporal}

Não foi encontrado padrão significativo de variação de cada índice durante a realização da pesquisa (três conjuntos em 18 meses).
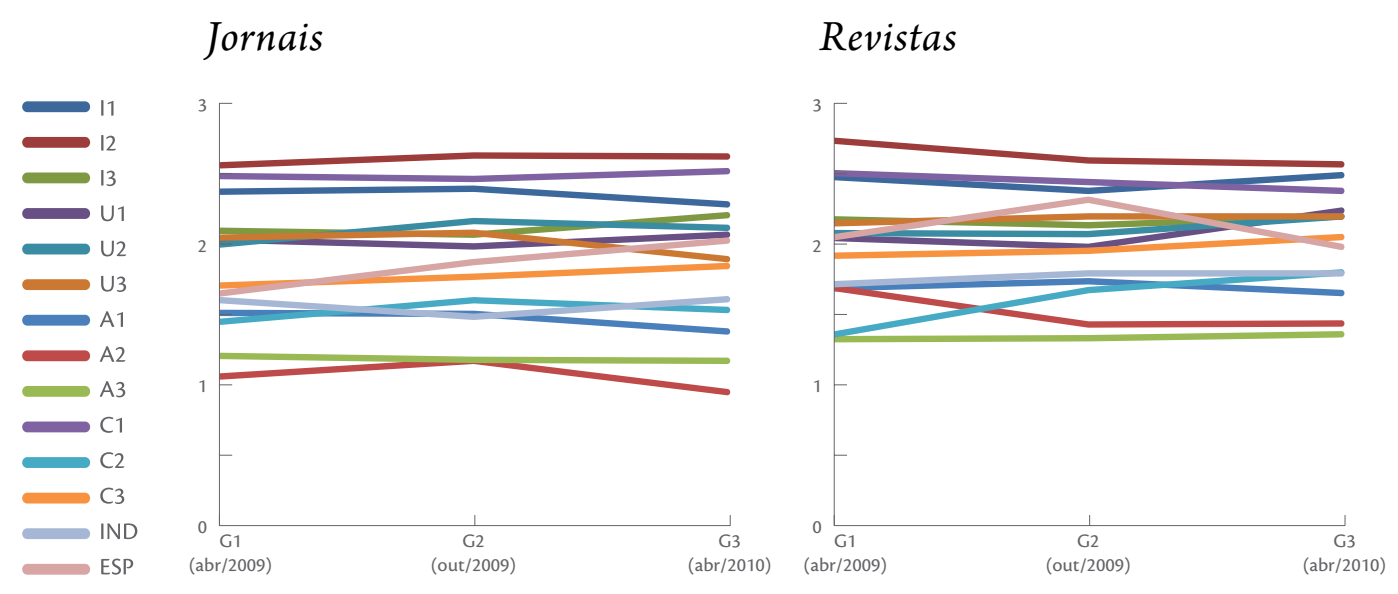

- Esportes - verificou-se grande ocorrência de infográficos, mas com avaliações abaixo da média em todos os elementos. Muitos infográficos da editoria são sumários de partidas de futebol, um formato padronizado e de leitura simples, mas sem aprofundamento de informações.

- Entretenimento - déficit em todos elementos, mas principalmente em conteúdo. A ocorrência de roteiros e sugestões culturais e a divulgação de rumores foram alguns dos fatores que contribuíram negativamente nesse índice, por conterem informações rasas e de baixa visualidade. 


\section{CONSIDERAÇÕES FINAIS}

Ao longo da pesquisa, percebeu-se que os estudos sobre infográficos estão em crescimento, junto com o uso desse recurso. No entanto, esses estudos ainda esbarram em deficiências teóricas que refletem ambiguidades presentes nas áreas que o compõem. Por isso, a revisão bibliográfica buscou abranger as diversas áreas relacionadas ao desenvolvimento do infográfico - da paleografia ao design da informação - para estabelecer bases para sua conceituação.

Encontrou-se um recurso jornalístico que usa a quebra da linearidade textual não apenas para mudar o ritmo da leitura, mas também para criar significados e análises. Após mais de dois séculos de lenta evolução, os infográficos agora sofrem mudanças rápidas que acompanham as modificações de toda a prática jornalística.

A análise de conteúdo registrou um panorama de transição também nos veículos noticiosos brasileiros. Essa transição é mais perceptível na comparação entre veículos que se posicionam na vanguarda e veículos que fazem investimentos mais modestos na área. Ao lado de fórmulas prontas para resumos de jogos de futebol já aparecem formatos criativos e aprofundados na sóbria cobertura política.

\subsection{Resultados da ANÁlise de CONTEÚdo}

A avaliação de infográficos dos jornais e revistas selecionados no corpo de pesquisa encontrou perfil similar em todas as publicações. Uma característica comum foi o alto índice na avaliação da integridade (I) das peças, que teve média de 7,21 pontos (dentro da expectativa formulada como hipótese c). Isso indica que o infográfico é visto como parte do discurso jornalístico, respeitando seus quesitos de precisão e clareza.

Outra característica verificada em todas as publicações foi a seleção adequada de dados representados no infográfico $(\mathrm{C} 1)$, que obteve média de 2,51 pontos. No entanto, esses dados nem sempre eram aprofundados (C3), ficando com índice médio de 1,85. Isso sugere, portanto, que o infográfico não é usado como ferramenta de análise ou reflexão, com predomínio de sumários que apenas resumem os pontos centrais da reportagem (de acordo com hipótese e).

A baixa complexidade do conteúdo afetou também a avaliação da usabilidade (U) dos infográficos. A apresentação da informação é organizada e faz uso de ferramentas comuns e de fácil compreensão (como sumários em itens, mapas e gráficos quantitativos simples). Mas essa apresentação não reforça ou enfatiza conteúdos de acordo com seus níveis de importância, gerando diagramas uniformes com pontuação média de 6,28 (dentro do esperado na hipótese f). 
Outra evidência relacionada foi o uso baixo de elementos de comunicação visual (A2) e visualidade da informação (C2), que obtiveram índices médios de 1,20 e 1,57 pontos respectivamente (conforme parte da hipótese $\mathrm{d}$ ).

A baixa complexidade da informação, a falta de hierarquização na representação e o uso insuficiente de recursos de visualidade indicam tendência estetizante na infografia presente nos veículos analisados.

Essa tendência, como já foi argumentado, não significa que infográficos tenham grande força gráfica. Impacto visual (A1) e produção elaborada (A3) tampouco apresentaram índices elevados, obtendo índices respectivos de 1,54 e 1,24 pontos (contradizendo parte da hipótese d). Essa observação também se relaciona com a grande quantidade de sumários encontrados - elementos textuais e de produção simples.

Nos eixos subordinado-independente e enciclopédico-específico, os resultados apresentaram alguma variação entre os veículos.

O índice médio de independência foi de 1,63 pontos (dentro da expectativa da hipótese a), refletindo predominância do textual sobre outros tipos de linguagem. $\mathrm{O}$ corpo de pesquisa foi formado por veículos que, mesmo direcionados a públicos de classes específicas, representam formatos mais tradicionais, que reforçam o texto verbal e linear.

No entanto, notou-se que as revistas obtiveram pontuação um pouco mais alta (média de 1,79), apontando uma diferença entre os formatos. Os jornais Folha de S. Paulo (índice médio de 1,84 pontos) e Agora São Paulo (1,91 pontos) também conseguiram pontuações acima dos demais veículos do mesmo tipo, apontando tendência do grupo editorial responsável pelas duas publicações - que foi um dos primeiros a utilizar o recurso no Brasil e já recebeu diversos prêmios internacionais com infográficos da Folha.

O índice de especificidade médio foi de 1,94 (de acordo com a hipótese b), refletindo em infográficos valores de noticiabilidade como atualidade e novidade. Com os mesmos princípios do índice de independência, as revistas semanais (média de 2,15 pontos) e os jornais Folha $(2,10)$ e Agora $(2,13)$ foram os únicos com índice de especificidade superior a 2 pontos.

Os jornais do grupo Folha tiveram, no geral, desempenho superior à média dos jornais diários - principalmente nos índices de independência, especificidade e aparência (hipótese i). No entanto, essa diferença não foi tão significativa. O jornal O Estado de S. Paulo (72) publicou maior quantidade de infográficos que a Folha de S. Paulo (50) nos dias analisados e também obteve pontuações um pouco superiores em integridade, usabilidade e conteúdo.

Já a disputa entre Época e Veja foi marcada pelo uso mais constante de infográficos na publicação da editora Globo (59 a 30). Esse uso constante e até padronizado reduziu o índice médio de aparência (A) e conteúdo (C) da Época, principalmente por conta de perfis de entrevistados apresentados na forma de itens.

A comparação entre revistas e jornais encontrou variações pequenas, mas favoráveis às revistas em quase todas as características analisadas. Mas essas variações foram pequenas mesmo em componentes de complexidade (A3 e C2), sendo insuficientes para representar tendência (refutando hipótese g). Mesmo assim, a aparência (A) das peças das revistas se- 
manais (4,58 pontos) mostrou-se superior às dos jornais diários ( 3,77 pontos), como seria esperado com as diferenças de periodicidade e formato.

$\mathrm{Na}$ comparação entre editorias, os infográficos de Ciência e Tecnologia apresentaram índices superiores à média nos elementos do eixo estatizante-analítico (de acordo com hipótese $h$ ), com diferença mais significativa na aparência (A): 5,31 pontos, contra média geral de 3,98. A análise também encontrou bons resultados em seções como Política e Economia - que valorizam contexto, explicação e confiabilidade de dados.

\subsection{ApliCAÇÃo do MODElo EM CONTEXTO DE PRODUÇÃo}

Nesse contexto, no qual convivem infográficos característicos de diversos períodos da evolução do formato, propõe-se a aplicação do modelo de caracterização e avaliação de infográficos (testado na análise de conteúdo) fora do âmbito acadêmico. Com critérios prédeterminados, o modelo é aplicado na forma de atribuição e contagem simples de pontos, o que possibilita a análise rápida e a elaboração de metas.

A utilização do modelo, no entanto, deve ter em vista que a pontuação máxima em todos os critérios nem sempre é necessária. Embora o caráter analítico seja desejável em certos infográficos, as limitações temporais dos produtores - que respondem a prazos de fechamento e precisam noticiar acontecimentos com agilidade - e dos leitores - que também se informam por meio de sumários simples - abrem espaço para infográficos menos elaborados, mas ainda interessantes. 



\section{REFERÊNCIAS BIBLIOGRÁFICAS}

ABBOTT, H. Porter. Unnarratable knowledge: the difficulty of understanding evolution by natural selection. In: HERMAN, David (org.). Narrative theory and the cognitive sciences. Stanford: CSLI Publications, 2003. p. 143-162.

ALBERT, Pierre; TERROU, Fernand. História da imprensa. Tradução de Edison Darci Heldt. $1^{\text {a }}$ ed. São Paulo: Martins Fontes, 1990.

ARBACH, Jorge Mtanios Iskandar. $O$ fato gráfico: o humor gráfico como gênero jornalístico. São Paulo: USP, 2007. 1 vol. Tese (Doutorado em Ciências da Comunicação) - Programa de Pós-Graduação em Ciências da Comunicação, Escola de Comunicações e Artes, Universidade de São Paulo, São Paulo, 2007.

BARTHES, Roland; COMPAGNON, Antoine. Leitura. In: RUGGIERO, Romano (org.). Enciclopédia Einaudi. vol 11. Lisboa: Imprensa Nacional/Casa da Moeda, 1987. P. 184-206.

BERTIN, Jacques. A neográfica e o tratamento gráfico da informação. Tradução de Cecília Maria Westphalen. Curitiba: Editora da UFPR, 1986.

BLAKE, Reed H.; HAROLDSEN, Edwin O. Una taxonomía de conceptos dela comunicación. Tradução de Leticia Halperin Donghi. México: Ediciones Nuevomar, 1977.

BRANDT, Stephan A.; STARK, Lawrence W. Spontaneous eye movements during visual imagery reflect the content of the visual scene. Journal of Cognitive Neuroscience, Cambridge: Massachusetts Institute of Technology, v. 9, n. 1, p. 27-38, jan. 1997.

BRUNER, Jerome. The narrative construction of reality. Critical Inquiry, Chicago: University of Chicago, v. 18, n. 1, p. 1-21, 1991.

CAIRO, Alberto. Infografía 2.0. Visualización interactiva de información en prensa. Madrid: Alamut, 2008.

CALABAÇA, Ricardo. Fisiologia da leitura. Cadernos de tipografia, n. 3, p. 21-23, set. 2007.

CLEVELAND, William S. The Elements of graphing data. Revised edition. New Jersey: ATઐT Bell Laboratories, 1994. 
COMASSETTO, Leandro Ramires. As razões do título e do lead: uma abordagem cognitiva da estrutura da notícia. Concórdia: UnC, 2003.

COSTA, Joan. La Esquemática. Barcelona: Paidós, 1998.

CROWELL, Alfred A. Creative news editing. $2^{\mathrm{a}}$ imp. Dubuque: W.C. Brown Company Publishers, 1962.

DENIS, Rafael Cardoso. Uma introdução à história do design. $1^{\mathrm{a}}$ reimpressão. São Paulo: Edgard Blücher, 2000.

DE PABLOS, José Manuel. Infoperiodismo. El Periodista como Creador de Infografia. Madrid: Editorial Síntesis, 1999.

DERVIN, Brenda. Chaos, order, and Sense-Making: a proposed theory for information design. In: JACOBSON, Robert (org.). Information Design. $1^{\text {a }}$ imp. paperback. Cambridge: MIT Press, 2000. p. 35-57.

DONDIS, Donis A. Sintaxe da Linguagem Visual. Tradução de Jefferson Luiz Camargo. $3^{\mathrm{a}}$ ed. São Paulo: Martins Fontes, 2007.

EDITORA ABRIL. Manual de estilo Editora Abril: como escrever bem para nossas revistas. Rio de Janeiro: Nova Fronteira, 1990

ERBOLATO, Mário L. Técnicas de codificação em jornalismo. $3^{\text {a }}$ ed. Petrópolis: Vozes, 1984 .

ERREA, Javier. The future of graphics. SND Update. January 2004. p. 6-7. North Kingstown.

FINBERG, Howard I.; ITUle, Bruce D. Visual Editing. A graphic guide for journalists. Belmont: Wadsworth Publishing Company, 1990.

FLUSSER, Vilém. O mundo codificado: por uma filosofia do design e da comunicação (organizado por Rafael Cardoso). Tradução de Raquel Abi-Sâmara. $1^{\text {a }}$ reimp. São Paulo: Cosac Naify, 2008.

FOLHA DE S. PAULO. Manual da Redação. $10^{a}$ ed. revista e atualizada. São Paulo: PubliFolha, 2006.

FONTANA, Rubén. On signs and centuries. Tradução de Peggy Jones e Martin Schmoller. 
In: FRASCARA, Jorge (org.). Designing effective communications. Creating contexts for clarity and meaning. $1^{\mathrm{a}}$ ed. New York: Allworth Press, 2006. p. 173-185.

FRIENDLY, Michael. A brief history of data visualization. In: CHEN, Chun-houh; HÄRDLE, Wolfgang; UNWIN, Antony (org.). Handbook of data visualization. Berlin: Springer, 2006. p. $15-56$.

FUSCA, Carla Jeanny. O processo de abreviação em salas de bate-papo: regularidades e fatores que condicionam seu uso. Simelp - Simpósio mundial de estudos de língua portuguesa, 2008, São Paulo.

GARCIA, Luiz. O Globo: manual de redação e estilo. 19ª ed. São Paulo: Globo, 1998

GARCÍA, Mario R. Diseño y remodelación de periódicos. Pamplona: Eunsa, 1984.

GERRIG, Richard J; EGIDI, Giovanna. Cognitive psychological foundations of narrative experiences. In: HERMAN, David (org.). Narrative theory and the cognitive sciences. Stanford: CSLI Publications, 2003.p. 33-55.

GOODY, Jack; WATT, Ian. As conseqüências do letramento. Tradução de Waldemar Ferreira Netto. São Paulo: Editora Paulistana, 2006.

HELLER, Steven. Nigel Holmes on information design. New York: Jorge Pinto Books Inc, 2006.

HERMAN, David. Introduction. In: (org.). Narrative theory and the cognitive sciences. Stanford: CSLI Publications, 2003. p. 1-30.

Stories as tools for thinking. In: (org.). Narrative theory and the cognitive sciences. Stanford: CSLI Publications, 2003. P. 163-192.

HERSCOVITZ, Heloiza Golbspan. Análise de conteúdo em jornalismo. In: LAGO, Cláudia; BENETTI, Marcia (org.). Metodologia de pesquisa em jornalismo. $2^{\mathrm{a}}$ ed. Petrópolis: Vozes, 2008. p.123-142.

HIGOUNET, Charles. História concisa da escrita. Tradução (da $10^{a}$ edição corrigida) de Marcos Marcionilo. São Paulo: Parábola Editorial, 2003.

HOLMES, Nigel. Designer's guide to creating charts \& diagrams. New York: WatsonGuptill Publications, 1984 . 
HORN, Robert E. Information Design: emergence of a new profession. In: JACOBSON, Robert (org.). Information Design. $1^{\mathrm{a}}$ imp. paperback. Cambridge: MIT Press, 2000. p. 15-33.

HUERTA, Robert D. Giants of Delft. Lewisburg: Bucknell University Press, 2003.

JACOBSON, Robert. Introduction: why information design matters. In: , Robert (org.).

Information Design. $1^{\mathrm{a}}$ imp. paperback. Cambridge: MIT Press, 2000. P. 1-10.

KANNO, Mário. Os dois gráficos que eu mais gosto de mostrar em um seminário para jornalistas da Abraji. Disponível em: [www.scribd.com/doc/8405991/SeminarioKannoAbraji]. Acesso em: 11 abr. 2009.

KEEBLE, Richard. The newspapers handbook. (reprint) Routledge, 1995.

KOVACH, Bill; ROSENSTIEL, Tom. Os elementos do jornalismo. Tradução de Wladir Dupont. São Paulo: Geração Editorial, 2003.

KUNCZIK, Michael. Conceitos de jornalismo: Norte e Sul. Manual de Comunicação. Tradução de Rafael Varela Jr. São Paulo: Edusp/Com-Arte, 1997.

LAGE, Nilson. Linguagem jornalística. São Paulo: Ática, 1985.

LIVERSEDGE, Simon P.; FINDLAY, John M. Saccadic eye movements and cognition. Trends in Cognitive Sciences, Londres: Elsevier Ltd, v. 4, n. 1, p. 6-14, jan. 2000.

LUSTOSA, Elcias. O texto da notícia. Brasília: Editora UnB, 1996.

MACY, Sheryl; ANDERSON, Elizabeth; KRYGIER, John. Interactivity and meaning. In: JACOBSON, Robert (org.). Information Design. $1^{\text {a }}$ imp. paperback. Cambridge: MIT Press, 2000. p. 293-299.

MANGUEL, Alberto. Lendo imagens: uma história de amor e ódio. Tradução de Rubens Figueiredo, Rosaura Eichenberg, Cláudia Strauch. São Paulo: Companhia das Letras, 2001.

. Uma história da leitura. Tradução de Pedro Maia Soares. $2^{\mathrm{a}}$ ed. São Paulo: Companhia das Letras, 2002.

MARQUES DE MELO, José. Técnica do Lead. São Paulo: ECA-USP, 1972. . Prefácio. In: LAGO, Cláudia; Benetti, Marcia (org.). Metodologia de pesquisa em 
jornalismo. $2^{\text {a }}$ ed. Petrópolis: Vozes, 2008.

MARTINS FILHO, Eduardo Lopes. Manual de redação e estilo de O Estado de S. Paulo. $3^{\text {a }}$ ed. revista e ampliada. São Paulo: O Estado de S. Paulo, 1997.

McCANDLESS, David. The Visual Miscellaneum: A Colorful Guide to the World's Most Consequential Trivia. $1^{\text {a }}$ ed. Collins Design, 2009.

. Interesting, easy, beautiful, true?. Information is Beautiful. Disponível em: [www. informationisbeautiful.net/2009/interesting-easy-beautiful-true/]. Acesso em: 10 nov. 2009.

MENDEZ, Rosemary B. Pompeu de Sousa: jornalista, professor e político. Congresso Brasileiro de Ciências da Comunicação. São Paulo: Intercom, 2006. Disponível em: [www.intercom. org.br/papers/nacionais/2006/resumos/Ro358-1.pdf]. Acesso em: 20 jul. 2010.

MEYER, Eric K. Designing infographics. Indianapolis: Hayden Books, 1997.

MIJKSENAAR, Paul. Visual Function. An introduction to information design. New York: Princeton Architectural Press, 1997

MÜLLER-BROCKMANN, Josef. História de la comunicación visual. Tradução de Joaquín Chamorro Mielke. $2^{\mathrm{a}}$ ed. Barcelona: Editorial Gustavo Gili, 2001.

NEUENDORF, Kimberly A. The content analysis guidebook. Sage, 2002.

NEURATH, Otto. International Picture language. The first rules of IsotyPE. Londres: Kegan Paul, Trench, Trubner \& Co. Ltd., 1936.

NIELSEN, Jakob. Usability 101: introduction to usability. UseIt.com. Disponível em: [www. useit.com/alertbox/20030825.html]. Acesso em: 21 mar. 2010.

NUNES, Carlos Alberto. Notícia e linguagem. Canoas: Editora daUlbra, 2003.

ONG, Walter. Oralidade e cultura escrita. A Tecnologização da palavra. Tradução de Enid Abreu Dobránszky. Campinas: Papirus, 1998.

PELTZER, Gonzalo. Jornalismo iconográfico. Tradução de Armando Pereira da Silva. Lisboa: Planeta Editora, 1992.

PEREA, Manuel; ACHA, Joana; CARREIRAS, Manuel. Eye movements when reading 
text messaging (txt msgng). Quarterly Journal of Experimental Psychology, Bristol: Experimental Psychology Society, abr. 2009.

PEREIRA, Gustavo Moraes Queirolo. Infojornalismo nos jornais diários: análise de coberturas no jornal Folha de S. Paulo. São Paulo: USP, 2006. 1 vol. Dissertação (Mestrado em Ciências da Comunicação) - Programa de Pós-Graduação em Ciências da Comunicação, Escola de Comunicações e Artes, Universidade de São Paulo, São Paulo, 2006.

PLAYFAIR, William. The commercial and political atlas ( $3^{\mathrm{a}}$ ed.). In: . The commercial and political atlas and statistical breviary. Cambridge: Cambridge University Press, 2005.

POYNTER INSTITUTE. EyeTracko7. A study of print and online news reading (apresentação). Disponível em: [www.poynter.org/resource/120458/Eyetracko7ASNE.pdf]. Acesso em: 3 abr. 2009.

RAMACHANDRAN, V. S.; BLAKESLEE, Sandra. Fantasmas no cérebro: uma investigação dos mistérios da mente humana. Tradução de Antonio Machado. Rio de Janeiro, Record, 2002.

RASKIN, Aza. The linguistic command line. Interactions, Austin: Association for Computing Machinery, v. 15, n. 1, p. 19-22, jan/fev. 2008.

ROAM, Dan. The back of the napkin. New York: Portfolio, 2008.

RODRIGUES, Jacira Werle. Reportagem impressa, estilo e manuais de redação: a construção da autoria nos textos do jornalismo diário. Santa Maria: Facos/UFSM, 2003.

SAENGER, Paul. A separação entre palavras e a fisiologia da leitura. Tradução de Valter Lellis Siqueira. In: OLSON, David R.; TORRANCE, Nancy. Cultura escrita e oralidade. São Paulo: Ática, 1995.

SCHMID, Maria Regina Leoni. Comunicação e informação no design de catálogos técnicos: um estudo comparativo de catálogos de engenharia. São Paulo: USP, 2006. 1 vol. Dissertação (Mestrado em Ciências da Comunicação) - Programa de Pós-Graduação em Ciências da Comunicação, Escola de Comunicações e Artes, Universidade de São Paulo, São Paulo, 2006.

SCHUDSON, Michael. The power of news. $2^{\mathrm{a}}$ imp. Cambridge: Harvard University Press, 1996.

SFEZ, Lucien. Crítica da Comunicação. Tradução de Maria Stela Gonçalves, Adail Ubirajara 
Sobral. Lisboa: Instituto Piaget, 1994.

SIMIONI, Ana Paula Cavalcanti. Di Cavalcanti ilustrador: trajetória de um jovem artista gráfico na imprensa (1914-1922). São Paulo: Editora Sumaré/Fapesp, 2002.

SVENBRO, Jesper. A Grécia arcaica e clássica: a invenção da leitura silenciosa. Tradução de Guacira Marcondes Machado. In: CAVALLO, Gugliemo; CHARTIER, Roger. História da leitura no mundo ocidental, vol. 1. São Paulo: Ática, 1998. p. 41-69.

TEIXEIRA, Tattiana. A presença da infografia no jornalismo brasileiro - proposta de tipologia e classificação como gênero jornalístico a partir de um estudo de caso. Revista Fronteiras Estudos midiáticos, São Leopoldo: Unisinos, v. IX, n. 2, p. 111-120, mai/ago. 2007.

TUFTE, Edward. The visual display of quantitative information. $2^{\mathrm{a}}$ ed. Cheshire, Graphics Press, 2007.

VIGNAUX, Georges. As ciências cognitivas. Tradução de Maria Manuela Guimarães. Lisboa: Instituto Piaget, 1991.

WAINER, Howard; SPENCE, Ian. Introduction. In: PLAYFAIR, William. The commercial and political atlas and statistical breviary. Cambridge: Cambridge University Press, 2005.

WARE, Colin. Visual thinking for design. Elsevier, MK, 2008.

WILDBUR, Peter; BURKE, Michael. Infográfica. Soluciones innovadoras en el diseño contemporáneo. Tradução de Andreu Cabré. Barcelona: Editorial Gustavo Gili, 1998.

WOLF, Maryanne. Proust and the squid. The story of the reading brain. New York: Harper Perennial, 2008.

WOLF, Mauro. Teorias das comunicações de massa. Tradução de Karina Jannini. $3^{\mathrm{a}}$ ed. São Paulo: Martins Fontes, 2008.

WURMAN, Richard Saul. Information anxiety. What to do when information doesn't tell you what you need to know. New York: Bantam Books, 1990. 



\title{
Índice
}

\author{
Abbott, H.P., 35 \\ Abstração, 60, 71-73, 71f5-2 \\ Visão, ponto cego \\ Acha, J., 26n14 \\ Albert, P., 58n56, 59 \\ Ambiguidade \\ combate pela escrita, $26,29-30$ \\ duplo sentido no jornalismo, 42 \\ legendas e rótulos, 30n23, 44, 51 \\ significado de imagens, 30, 44, 51 \\ Analfabetismo, 27-28, 28f2-3, 30, 44, 69. ver \\ também Escrita, democratização \\ Análise de conteúdo \\ corpo de pesquisa, 98 \\ definição, 97 \\ guia e formulário de análise, 99 \\ Anderson, E., 29 \\ Arbach, J.M.I., 29, 43n, 44-45 \\ Barthes, R., 32, 58 \\ Bertin, J. 51-52, 52f4-4 \\ Blake, R.H., 23, 38n29, 38n31 \\ Bliss, Charles. ver Blissymbols \\ Blissymbols, 31-32, 31f2-4, 69 \\ Brandt, S.A., 32-33 \\ Bruner, J., 35, 35n28 \\ Burke, M., 47, 57n53 \\ Cairo, A. \\ atuação profissional, 103 \\ como autor, 19, 19n, 48, 57n50, 58, 60, 73, \\ 73n64, 74, 76-77, 79, 82, 102 \\ Calabaça, R., 32 \\ Carreiras, M., 26n14 \\ Cérebro \\ Áreas especializadas, 33, 33f2-7 \\ Preenchimento, 72 \\ Visão. ver Visão, sistema visual; \\ Cleveland, W.S., 49-50, 50n, 50f4-2, 51, 52, \\ $82 \mathrm{n} 73$

\section{Cognição} \\ ciências cognitivas, 30n24 \\ infográfico e, 60, 73 \\ memória, 42,73 \\ processos cognitivos, 35,60 \\ Comassetto, L.R., 42 \\ Compagnon, A., 32, 58 \\ Comunicação \\ conceitos de, 23 \\ funções da, 23, 23n 3 \\ sentidos e, 23-24, 23n4, 29 \\ teorias da, 37 \\ Costa, J., 30, 47, 73n65 \\ Crowell, A.A., 101 \\ Denis, R.C., $47 \mathrm{n} 42$ \\ De Pablos, J.M., 58-60, 59n60, 73-74, 76n68 \\ Dervin, B., 47 \\ Design da informação \\ autores elementares. ver Bertin, J.; \\ Cleveland, W.S.; Holmes, N.; Playfair, \\ W.; Tufte, E. \\ definição, 47 \\ design e, 82-83 \\ jornalismo e, 54-55, 74. ver também \\ Infográficos \\ sense-making, 47 \\ teorias, 47 \\ visualização, 47-48, 73 \\ Dondis, D.A., 23, 27, 30, 46 \\ Egidi, G., 35 \\ Erbolato, M.L, 38n31, 39n34 \\ Errea, J., 76, 102
}




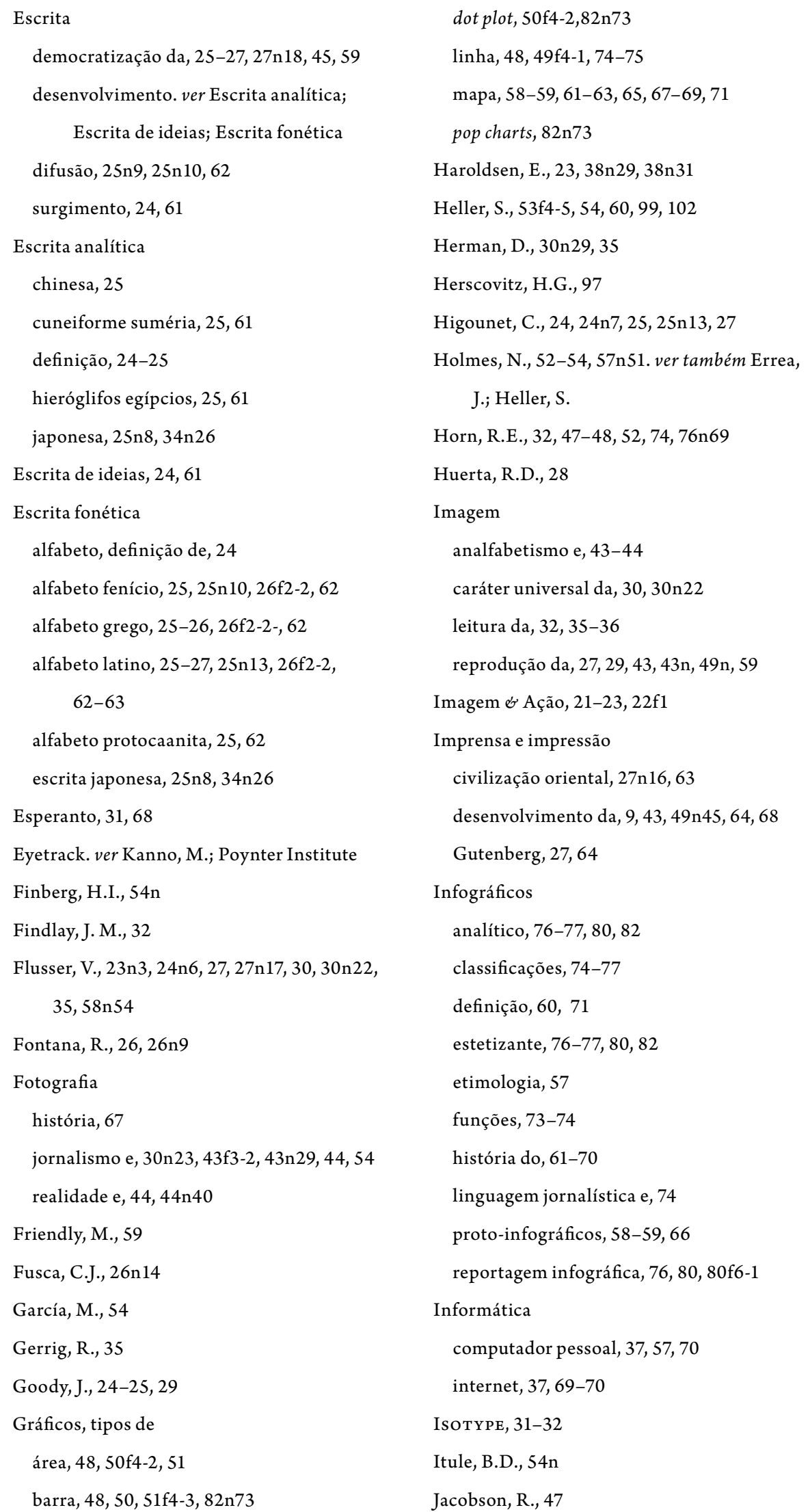




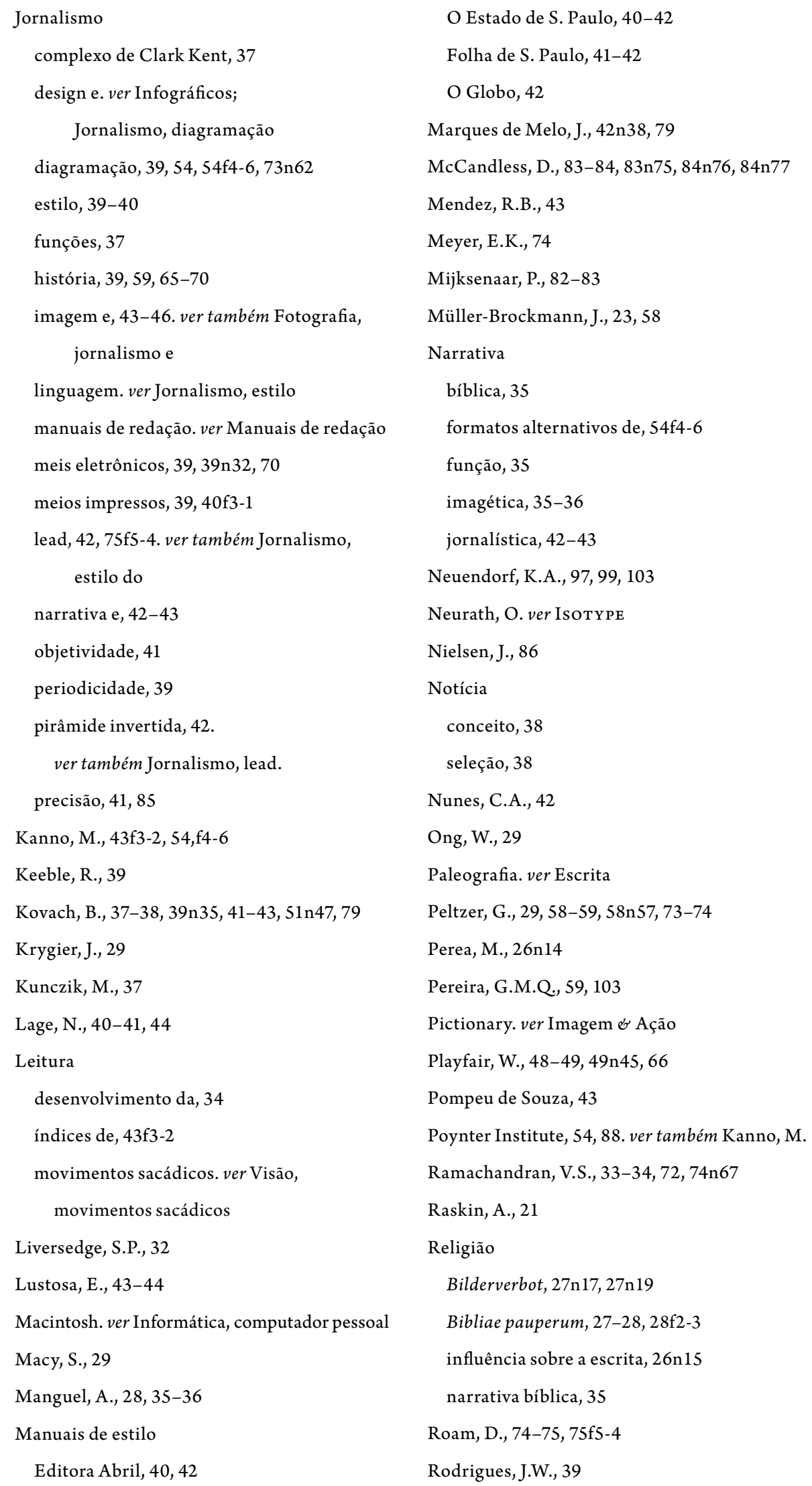


Rosenstiel, T., 37-38, 39n35, 41-43, 51n47, 79

Wurman, R.S., 23, 29, 35, 38-39, 47n43

Saenger, P., 26, 26n15, 34

Schmid, M.R.L., 82n71

Schudson, M., 37

Scriptura continua, 26, 26n 15

Sfez, L., 23

Simioni, A.P.C., 44

SMS, 26n14

Spence, I. ver Playfair, W.

Stark, L.W., 32-33

Svenbro, J., 26

Teixeira, T., 19, 20n2, 76, 76n68, 79-80, $102 \mathrm{n} 88,103$

Terrou, F., 58n56, 59

Tufte, E., 19, 48n44, 50-51, 77, 82n73

Universalidade da comunicação

Códigos, 24n6, 30, 30n22, 60

Linguagens universais. ver Esperanto; Blissymbolics

USA Today, 44f3-2, 55, 57-58, 70

Vignaux, G., 30n24

Visão

comunicação e, 23-24,

modos de ver, $75 \mathrm{f5}-4$

movimentos sacádicos, 32-33, 32f2-6

percepção gráfica, 52

percepção visual, 30, 49-50

ponto cego, 72-73

sistema visual, $33-34,34 \mathfrak{f} 2-8$

Vitruvius, $82-83$

Vogais, 26. ver também Escrita fonética, alfabeto grego; SMS

Visualização. ver Design da informação, visualização

Wainer, H. ver Playfair, W.

Ware, C., 71

Watt, I., 24-25, 29

Wildbur, P., 47, 57n53

Wolf, Maryanne, 34

Wolf, Mauro, 37 
Apêndice 
Agora São Paulo, 19/abr./2009 (1AGR)

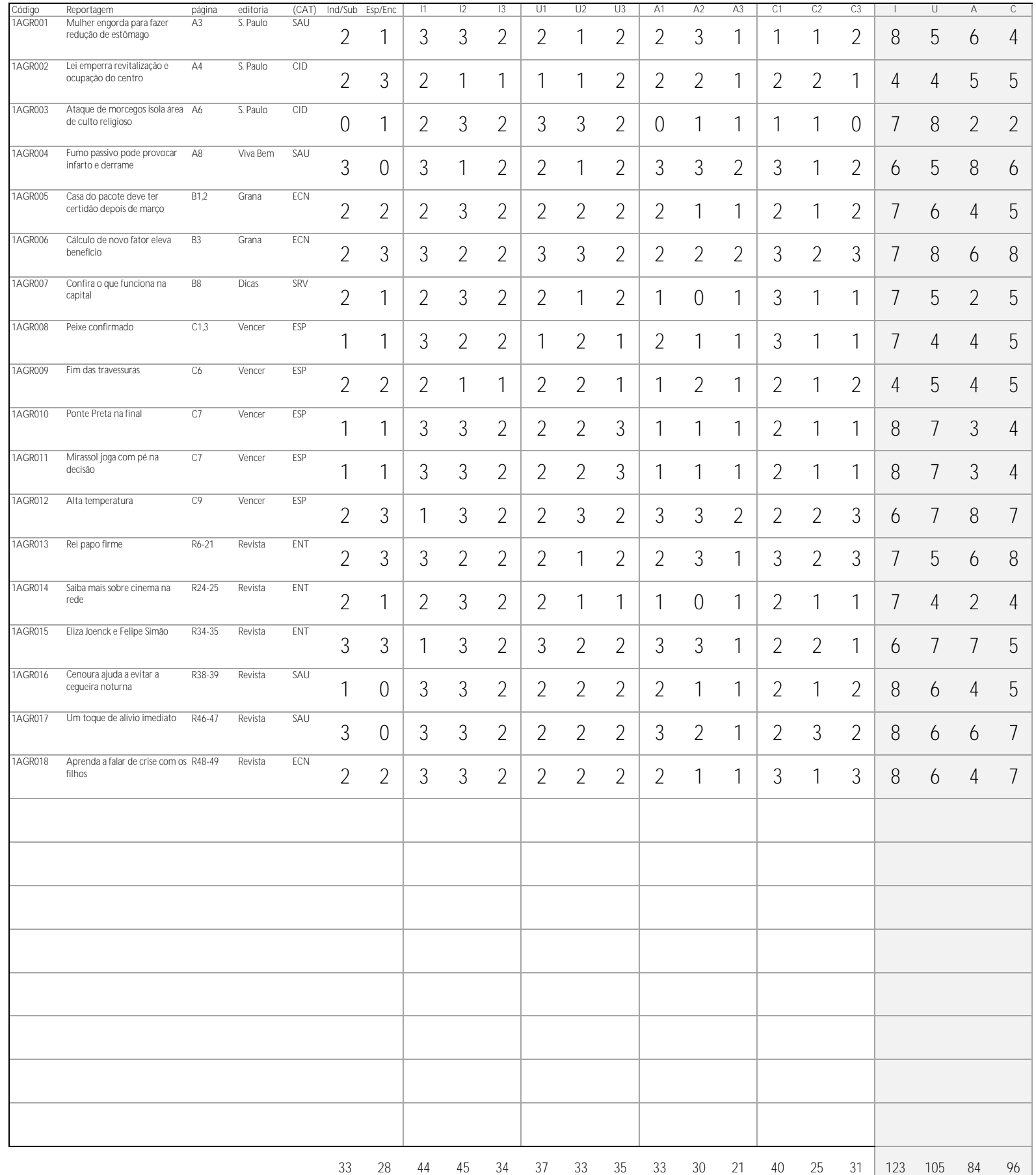

$\begin{array}{llllllllllllllllll}1,833 & 1,556 & 2,444 & 2,5 & 1,889 & 2,056 & 1,833 & 1,944 & 1,833 & 1,667 & 1,167 & 2,222 & 1,389 & 1,722 & 6,833 & 5,833 & 4,667 & 5,333\end{array}$ 


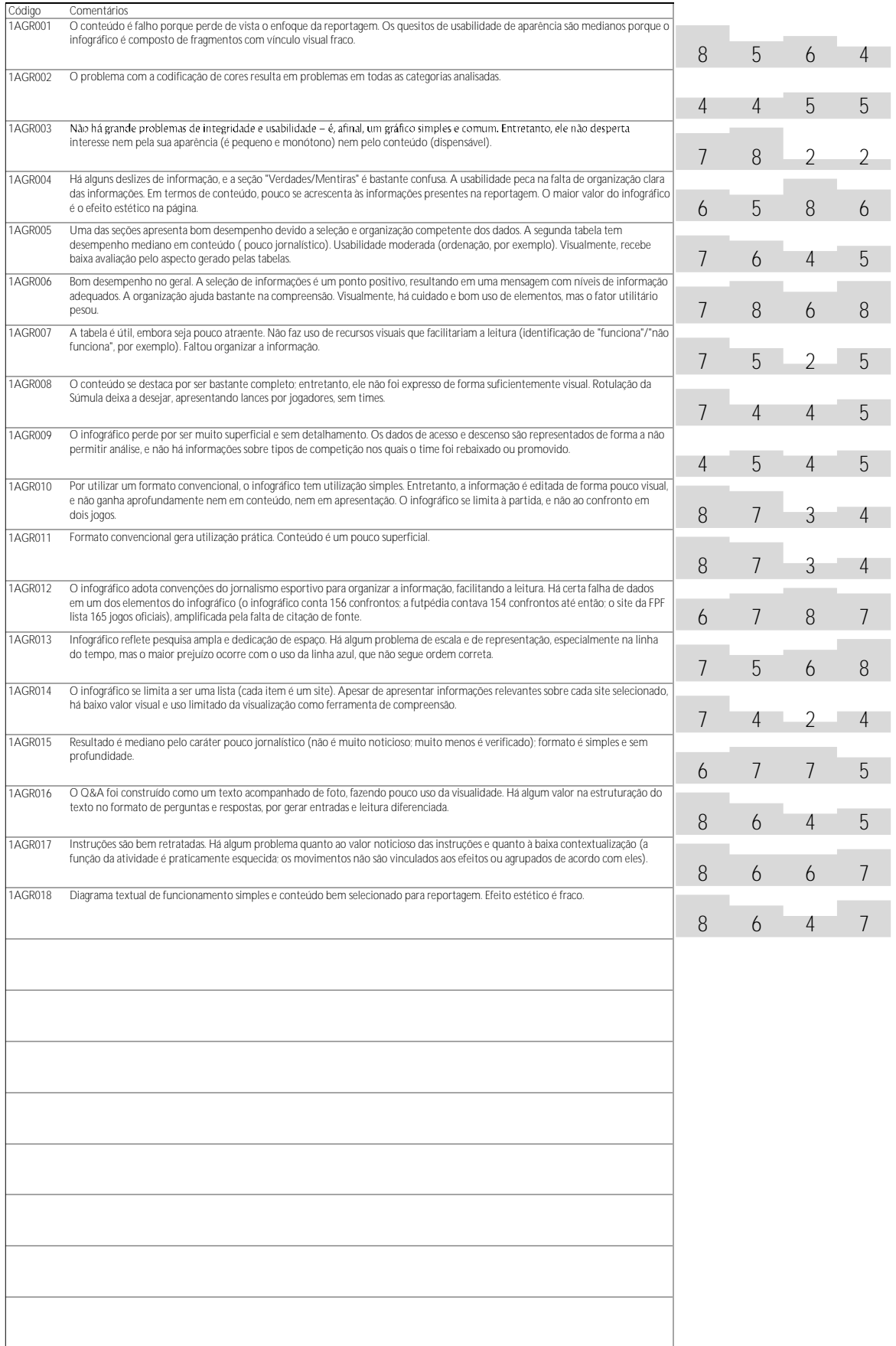


Agora São Paulo, 27/out./2009 (2AGR)

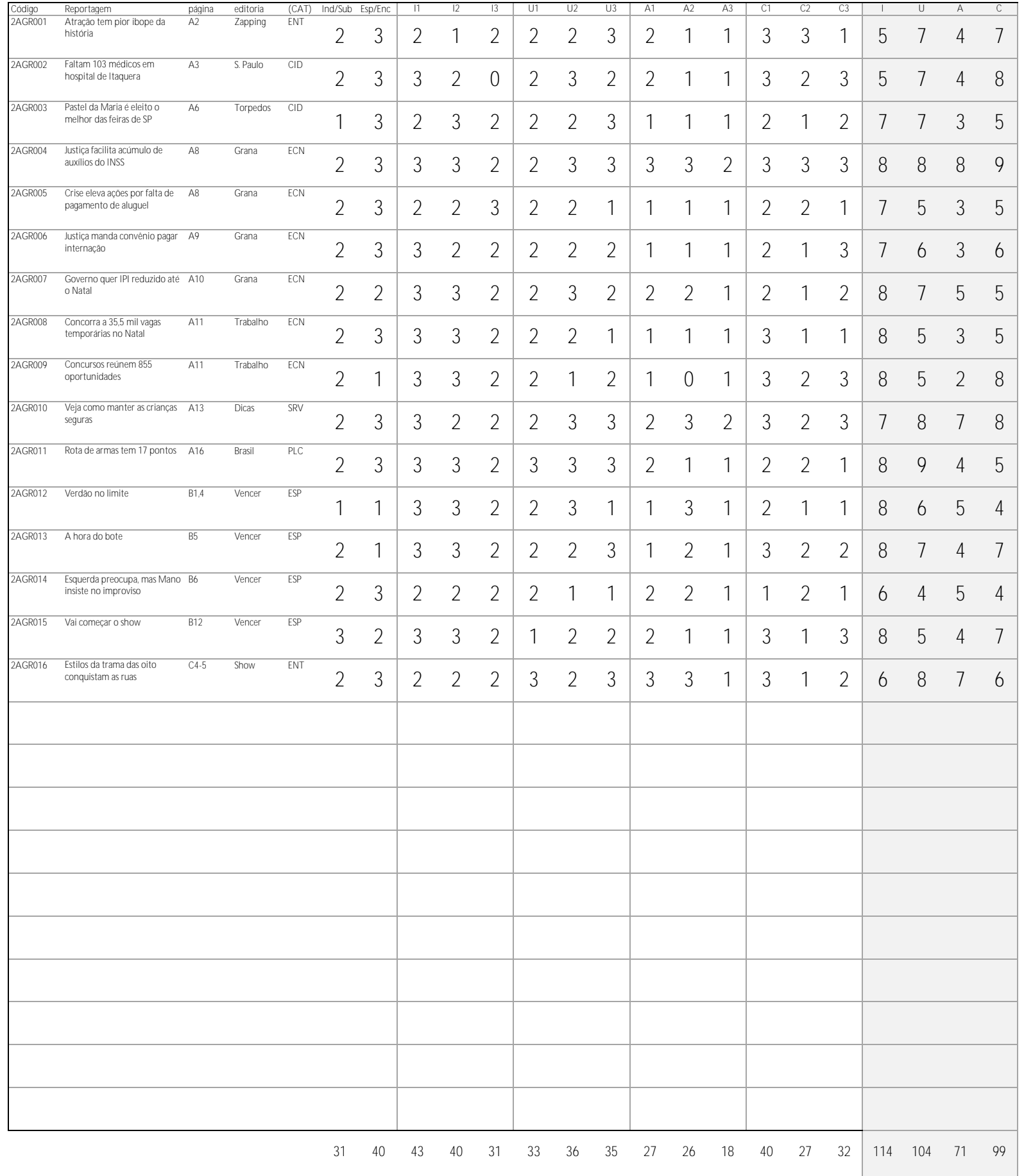

$\begin{array}{llllllllllllllllll}1,938 & 2,5 & 2,688 & 2,5 & 1,938 & 2,063 & 2,25 & 2,188 & 1,688 & 1,625 & 1,125 & 2,5 & 1,688 & 2 & 7,125 & 6,5 & 4,438 & 6,188\end{array}$

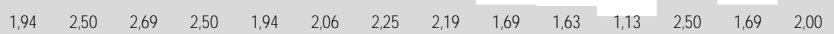




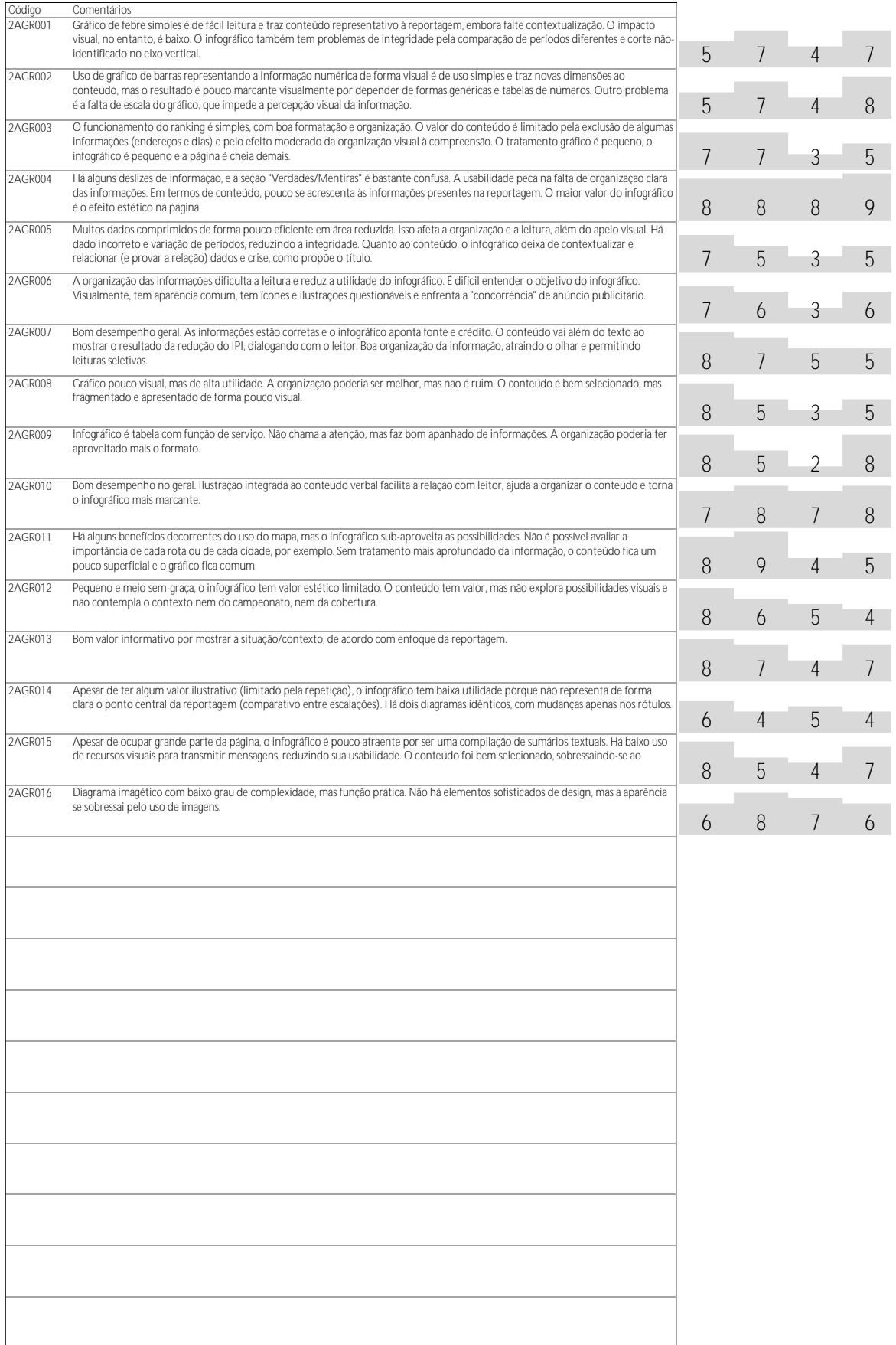


Agora São Paulo, 23/abr./2010 (3AGR)

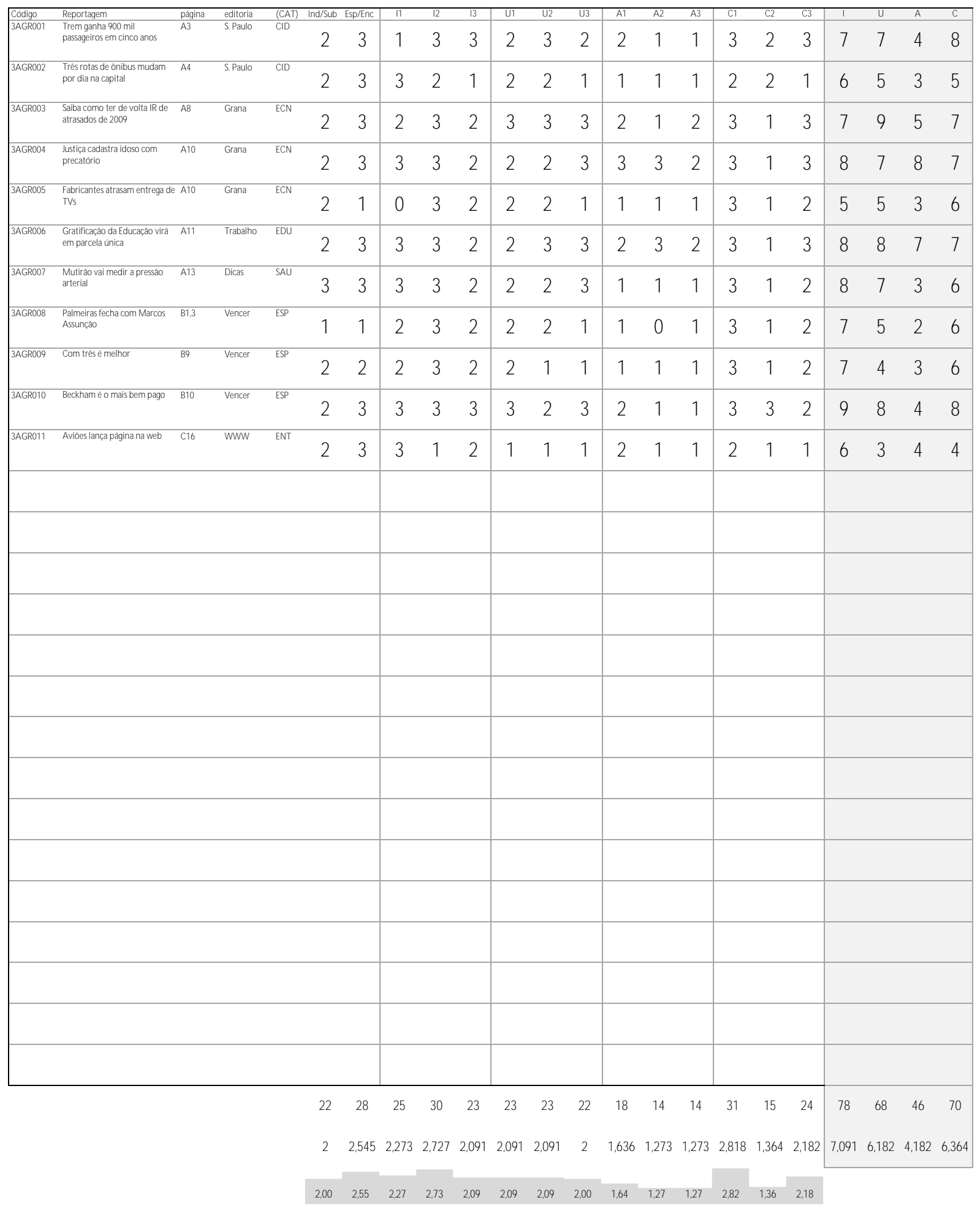




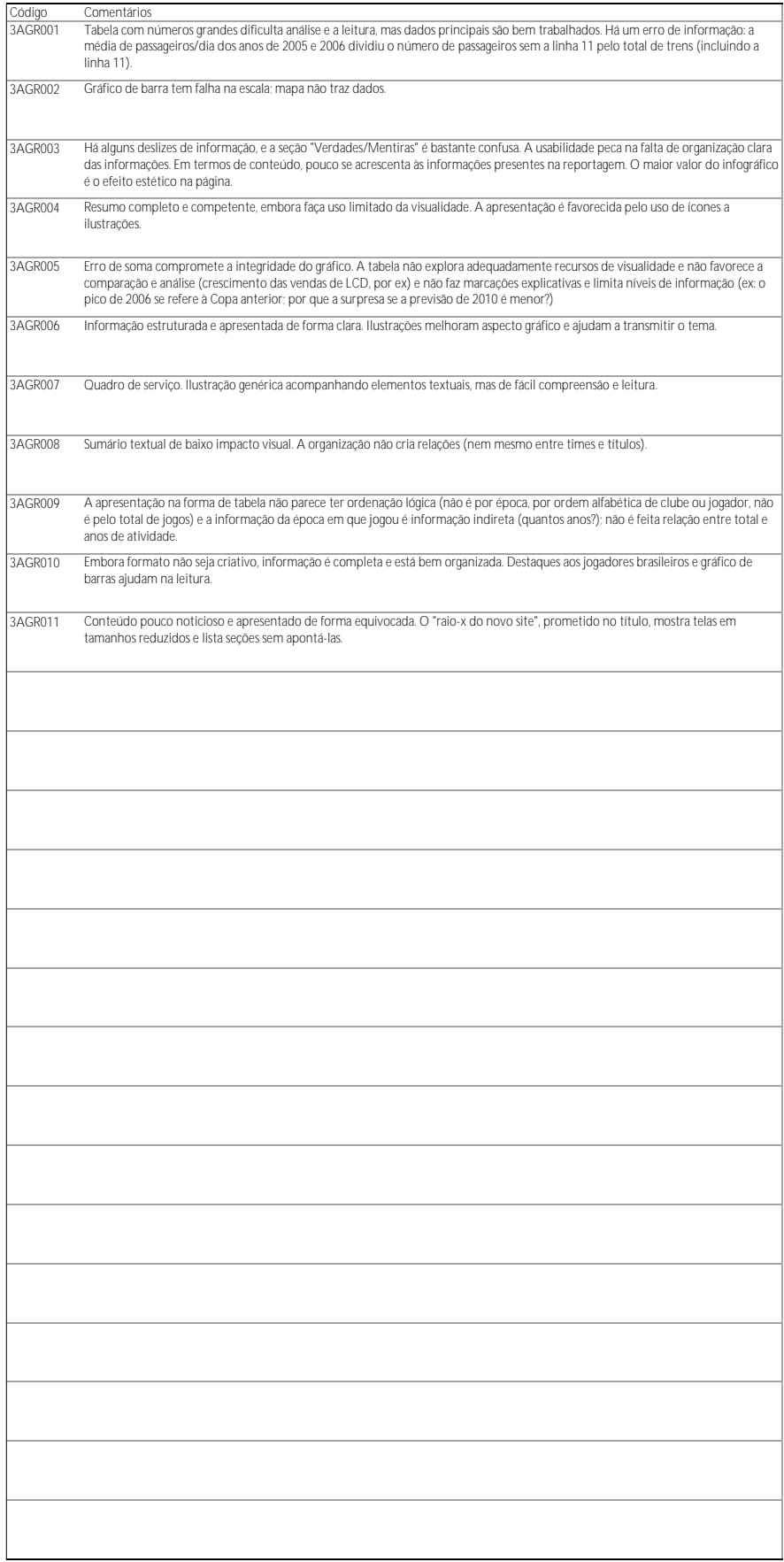

\begin{tabular}{|c|c|c|c|}
\hline 7 & 7 & & 8 \\
\hline 6 & 5 & 3 & 5 \\
\hline 7 & 9 & 5 & 7 \\
\hline 8 & 7 & 8 & 7 \\
\hline 5 & 5 & 3 & 6 \\
\hline 8 & 8 & 7 & 7 \\
\hline 8 & 7 & 3 & 6 \\
\hline 7 & 5 & 2 & 6 \\
\hline 7 & 4 & 3 & 6 \\
\hline 9 & 8 & 4 & 8 \\
\hline 6 & 3 & 4 & 4 \\
\hline
\end{tabular}


Diário de São Paulo, 19/abr./2009 (1DSP)

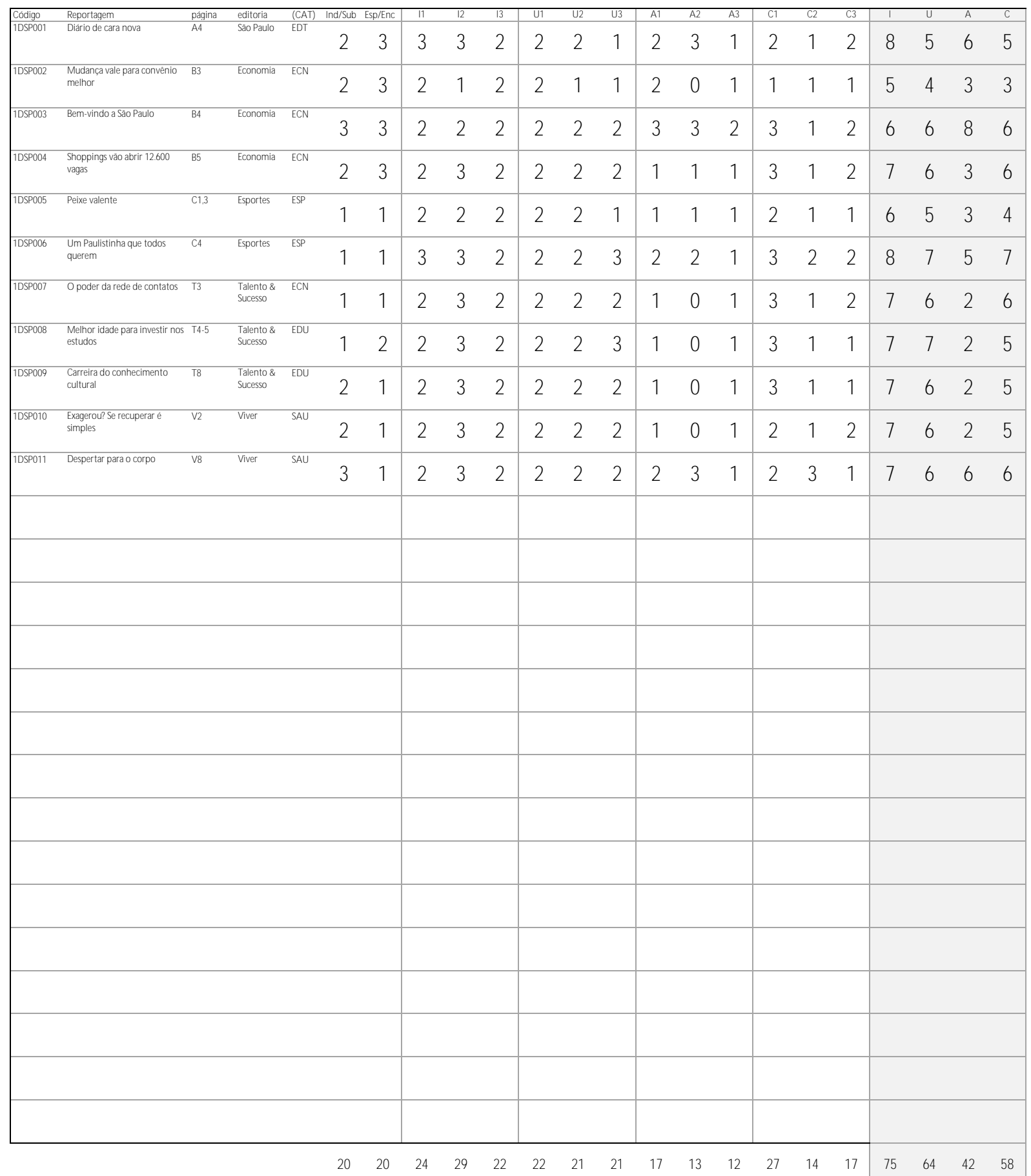

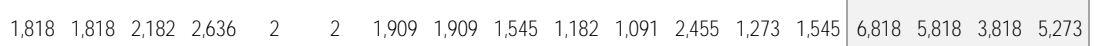




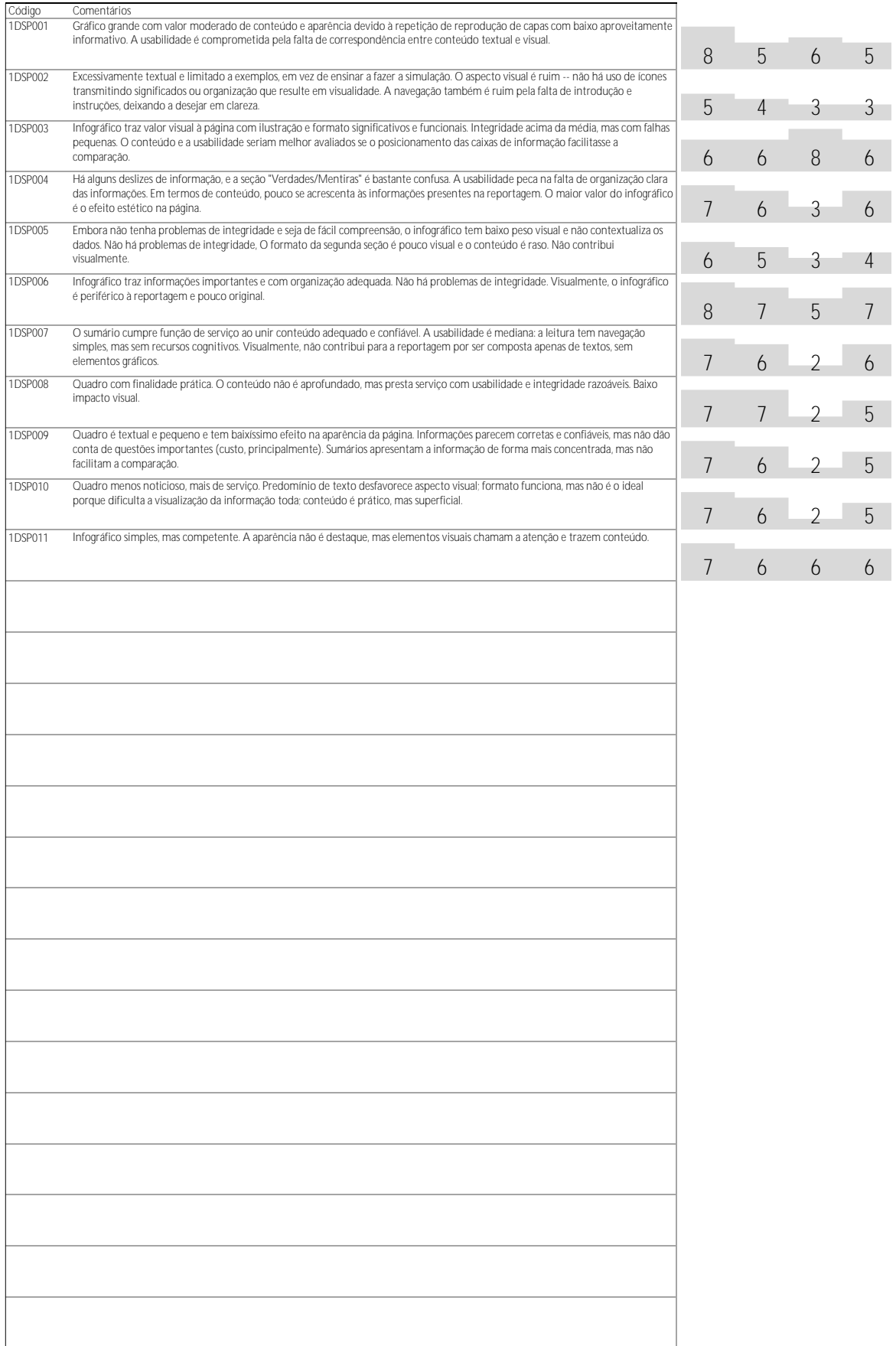


Diário de São Paulo, 27/out./2009 (2DSP)

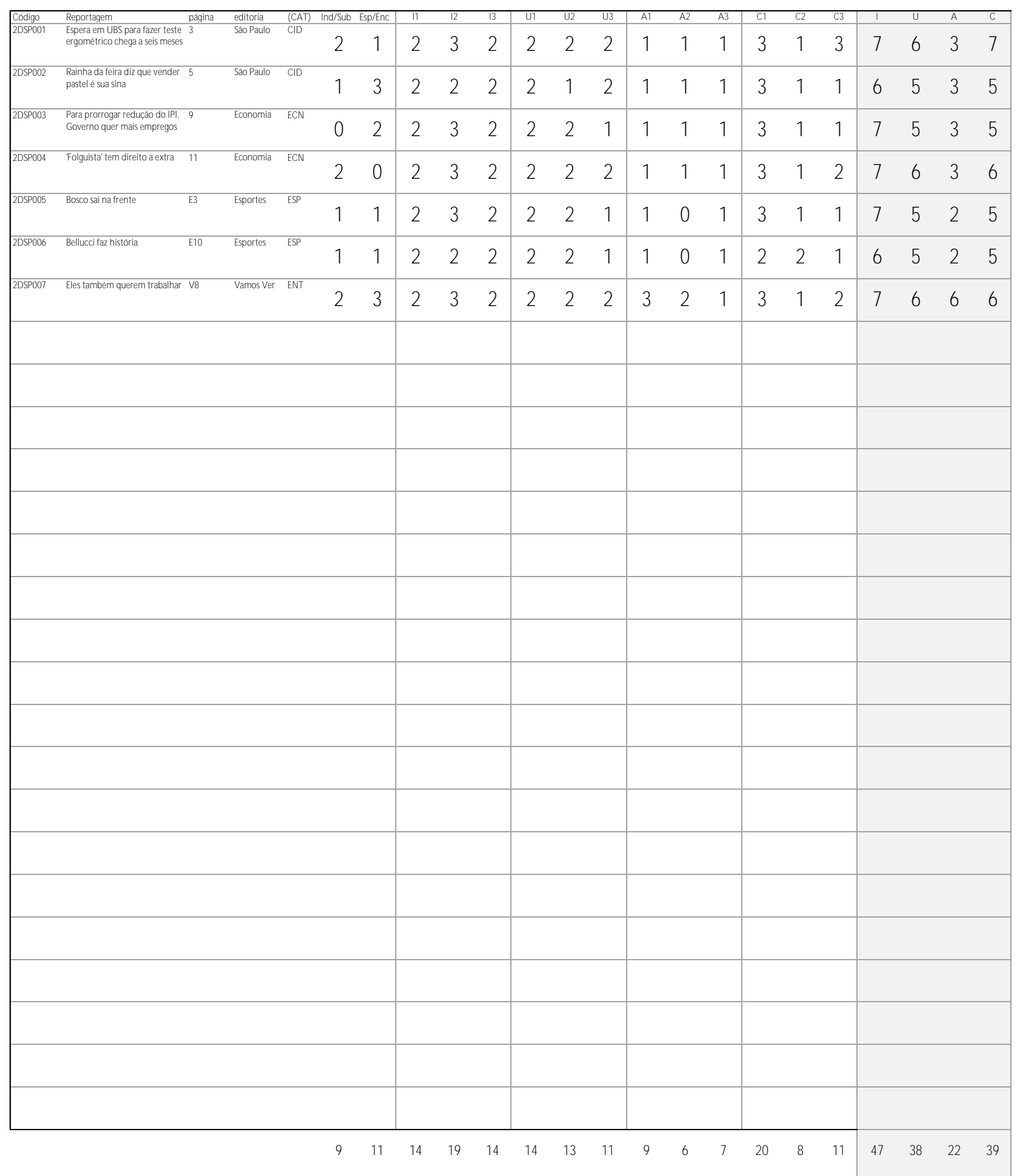

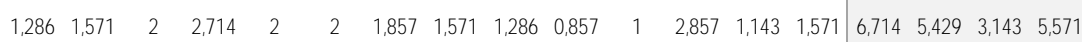




\begin{tabular}{|c|c|}
\hline \multirow[t]{2}{*}{ 2DŚdigo } & 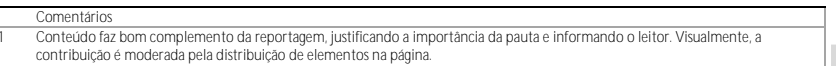 \\
\hline & 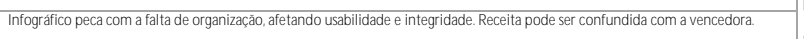 \\
\hline 2055003 & 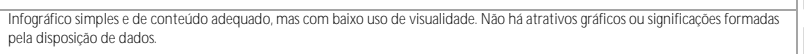 \\
\hline $205 P 004$ & 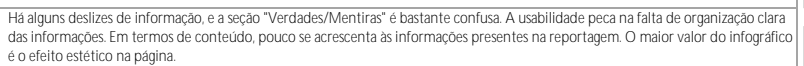 \\
\hline 2DSPP005 & 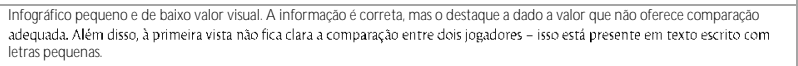 \\
\hline 2DSPP006 & Infográfico textual pequeno. Há valor informativo, mas sem contexto. Falta de explicaçăo atrapalha. \\
\hline 205P007 & 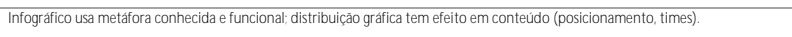 \\
\hline & \\
\hline & \\
\hline & \\
\hline & \\
\hline & \\
\hline & \\
\hline & \\
\hline & \\
\hline & \\
\hline & \\
\hline & \\
\hline & \\
\hline & \\
\hline & \\
\hline & \\
\hline & \\
\hline & \\
\hline & \\
\hline & \\
\hline & \\
\hline
\end{tabular}

\begin{tabular}{|lll|l|}
\hline 7 & 6 & 3 & 7 \\
\hline 6 & 5 & 3 & 5 \\
\hline 7 & 5 & 3 & 5 \\
\hline 7 & 6 & 3 & 6 \\
\hline 7 & 5 & 2 & 5 \\
\hline 6 & 5 & 2 & 5 \\
\hline 7 & 6 & 6 & 6 \\
\hline
\end{tabular}


Diário de São Paulo, 23/abr./2010 (3DSP)

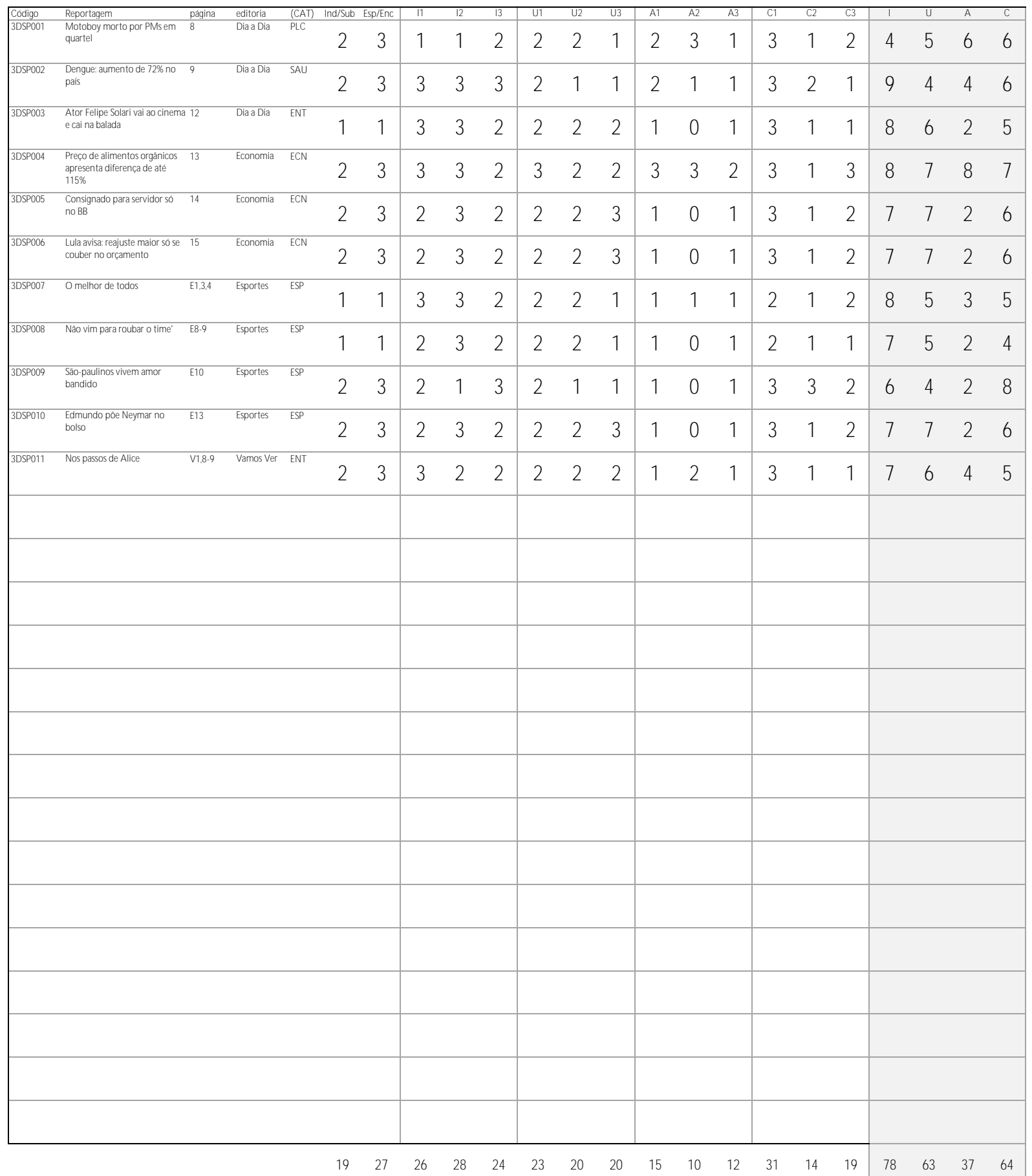

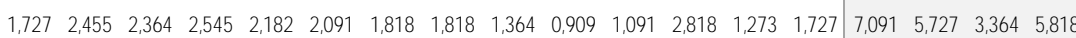




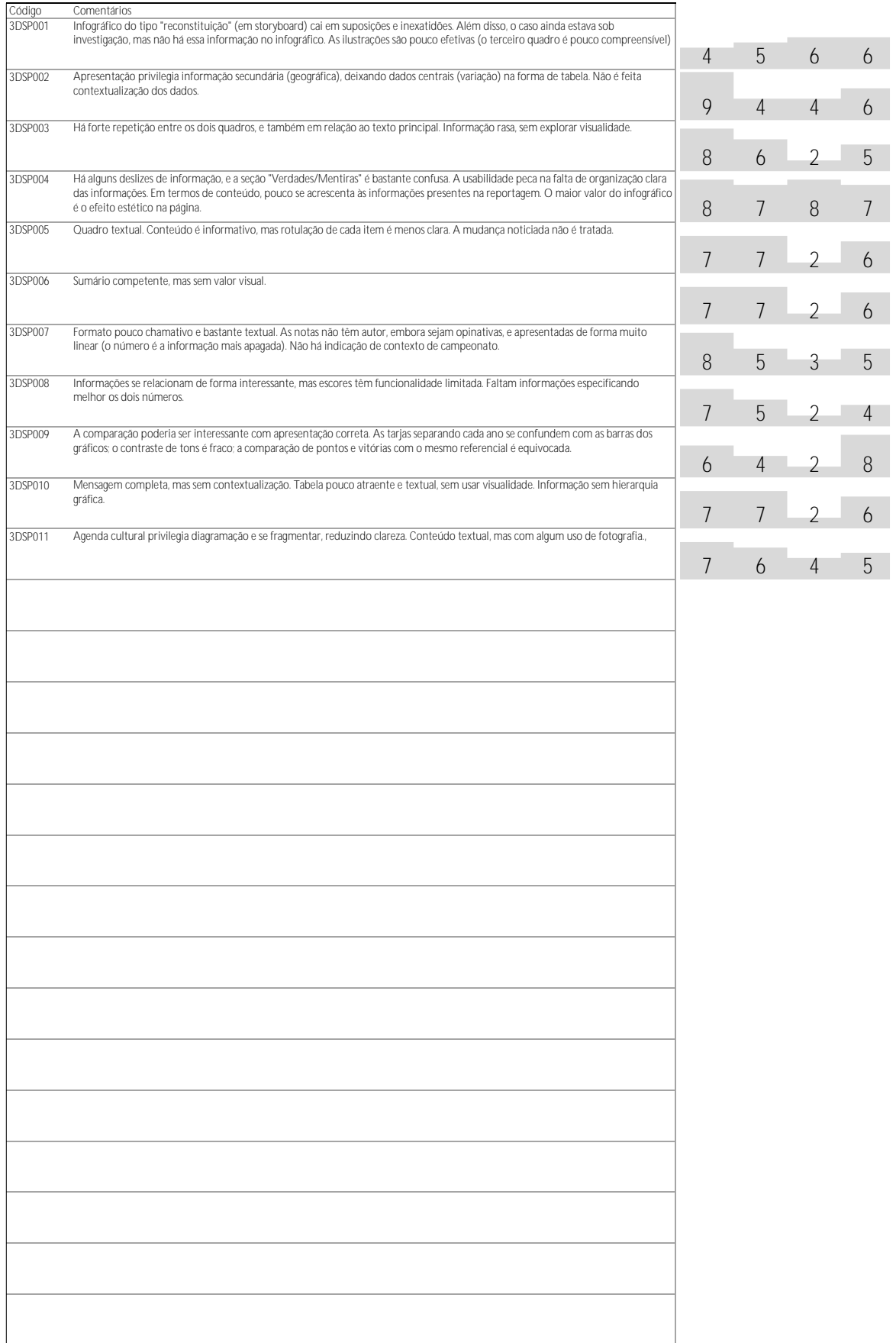


O Estado de S. Paulo, 19/abr./2009 (1ESP)

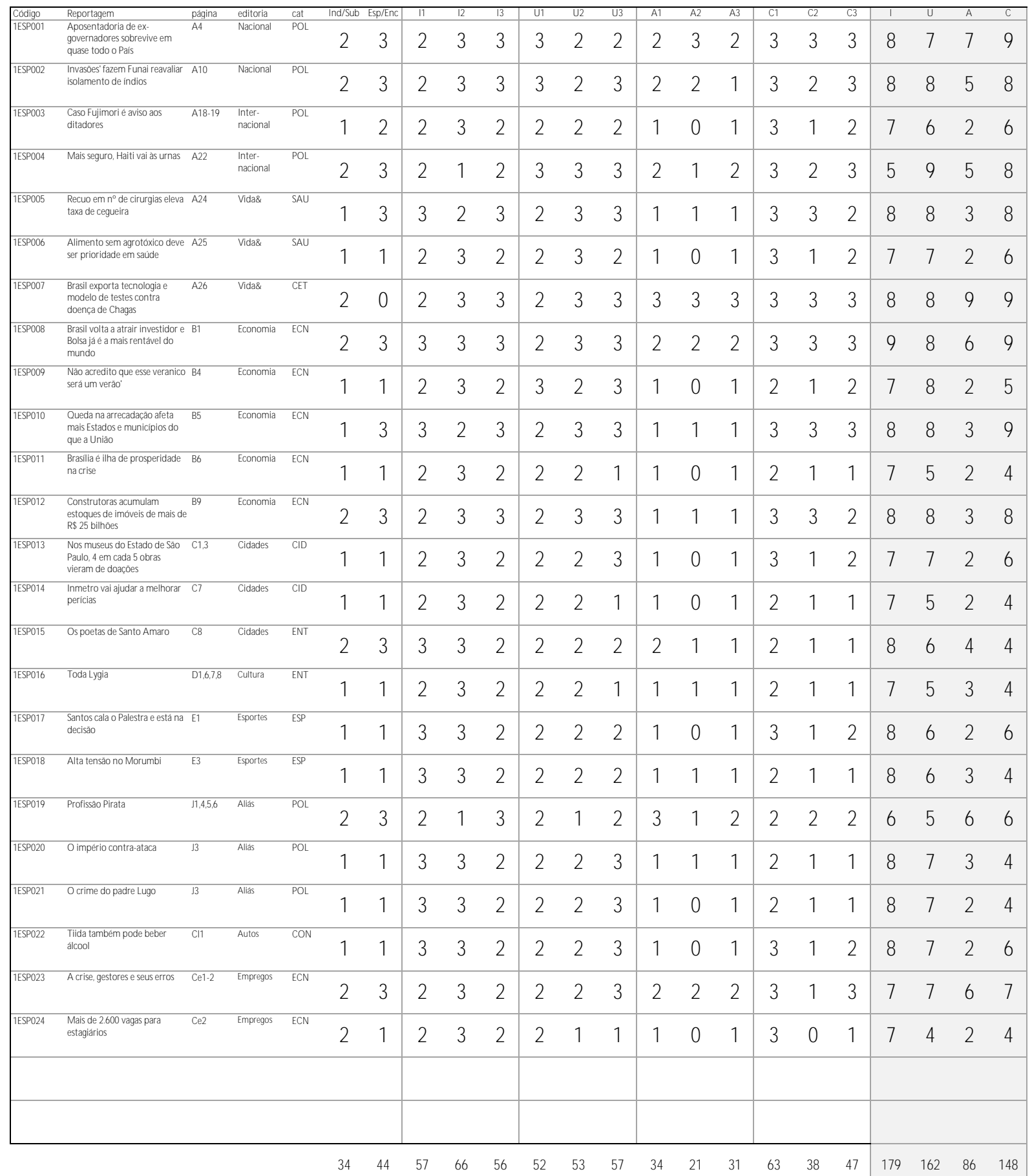

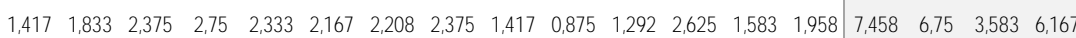
$\begin{array}{llllllllllllll}1,42 & 1,83 & 2,38 & 2,75 & 2,33 & 2,17 & 2,21 & 2,38 & 1,42 & 0,88 & 1,29 & 2,63 & 1,58 & 1,96\end{array}$ 


\begin{tabular}{|c|c|c|c|c|c|}
\hline $\begin{array}{l}\text { Código } \\
\text { 1ESPO01 }\end{array}$ & 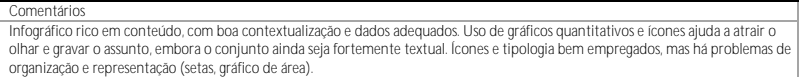 & 8 & 7 & 7 & 9 \\
\hline 1ESPO02 & $\begin{array}{l}\text { O mapa é um ponto positivo, pois faz uso da representaçăo visual para contextualizar e transmitiri informaçōes. Háiconese } \\
\text { marcaçōes que facilitam a leitura do mapa. O sumário, em foto-legenda, causa algum interesse, mas não é marcante. }\end{array}$ & 8 & 8 & 5 & 8 \\
\hline 1ESP003 & 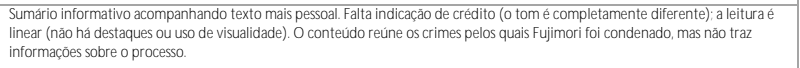 & 7 & 6 & 2 & 6 \\
\hline 1ESPO04 & 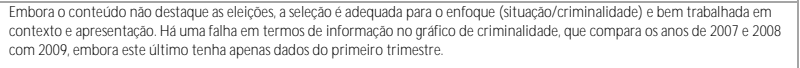 & 5 & 9 & 5 & 8 \\
\hline 1ESP005 & 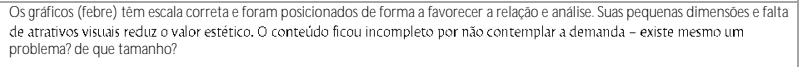 & 8 & 8 & 3 & 8 \\
\hline 1ESPO06 & $\begin{array}{l}\text { Resultado textual pouco atraente, mas conteúdo traz dados importantes que nä̆ foram contemplados na reportagem, destacando } 0 \\
\text { proprive estudo que gerou a reportagem. A leitura se simples, mas linear, sem explorar recursos gráficos ou apontar hierarquia no } \\
\text { conteúdo; }\end{array}$ & 7 & 7 & 2 & 6 \\
\hline 1ESPO07 & 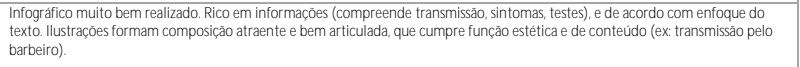 & 8 & 8 & 9 & 9 \\
\hline 1ESP008 & 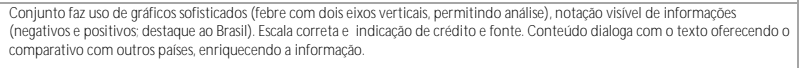 & 9 & 8 & 6 & 9 \\
\hline 1ESP009 & $\begin{array}{l}\text { Perfil de entrevistado. Baixo valor estético e conteúdo paralelo (năo se ap roxima do tema da entrevista). } 0 \text { sumário faz destaques } \\
\text { interessantes. }\end{array}$ & 7 & 8 & 2 & 5 \\
\hline ESPO10 & 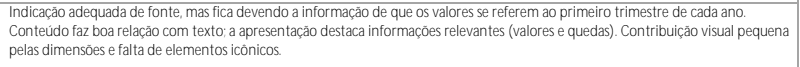 & 8 & 8 & 3 & 9 \\
\hline 1ESP011 & 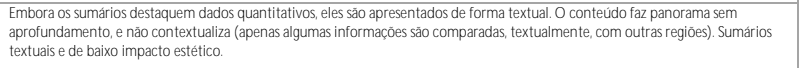 & 7 & 5 & 2 & 4 \\
\hline 1ESP012 & 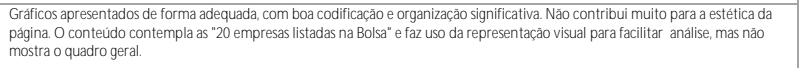 & 8 & 8 & 3 & 8 \\
\hline 1ESP013 & Conteúdo paralelo em sumário discreto. Nắo há componente icônico. & 7 & 7 & 2 & 6 \\
\hline 1ESP014 & 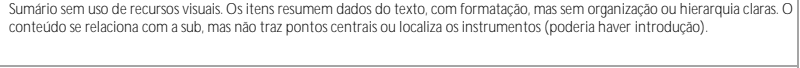 & 7 & 5 & 2 & 4 \\
\hline ESPO15 & 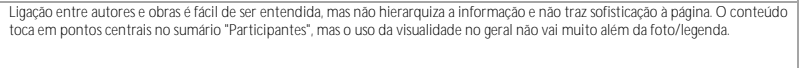 & 8 & 6 & 4 & 4 \\
\hline 1ESP016 & $\begin{array}{l}\text { Conteúdo complementa com dados factuais (titulos, datas) reportagem longa com componentes mais analíticos. Năo há uso de } \\
\text { visualidade ou recursos gráficos. }\end{array}$ & 7 & 5 & 3 & 4 \\
\hline 1ESP017 & $\begin{array}{l}\text { Resumo competente da partida, mas sem contextualizaçăo no campeonatoto. Baixo valor estetitico. A organizaçăo năo favorece a } \\
\text { hierarquia de informaçōes, mas ésimples e conhecida para esse tipo de conteúdo. }\end{array}$ & 8 & 6 & 2 & 6 \\
\hline 1ESP018 & $\begin{array}{l}\text { Ficha atécnica padrão para jogos de futebol. } 0 \text { contexto dos escores traz curiosidades, mas não faz menç̧ăo à disputa em dois jogos no } \\
\text { campeonato. }\end{array}$ & 8 & 6 & 3 & 4 \\
\hline 1ESP019 & 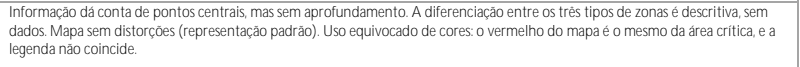 & 6 & 5 & 6 & 6 \\
\hline 1ESPO20 & $\begin{array}{l}\text { Sumário serve para indicar a cobertura que estás sendo comentada. Resumo se limita a pontos-chave e näo faz uso de visualidade. } \\
\text { Resultado é textual ea uunica imagem utilizada é reproduçăo pequena de um jornal. }\end{array}$ & 8 & 7 & 3 & 4 \\
\hline 1ESPO21 & $\begin{array}{l}\text { Sumário serve para indicar a cobertura que estás sendo comentada. Resumo se limita a pontos-chave e não faz uso de visualidade. } \\
\text { Resultado é textual e a única imagem utilizada a a reproduçăo pequena de um jornal. }\end{array}$ & 8 & 7 & 2 & 4 \\
\hline 1ESPO22 & $\begin{array}{l}\text { Dados têm origem indicadae săo organizados de forma clara. Năo há elementos icônicos, seja para ilustração, reforç̧o de conteúdo } \\
\text { ou informaçâo. O conteúdo é abrangente, mas solado. }\end{array}$ & & & & \\
\hline 1ESPO23 & $\begin{array}{l}\text { Uso interessante de ícones, ainda que o conjunto seja fortemente textual. Organizaç̧ão em tópicos facilita a navegaçăo, mas sem } \\
\text { hierarquia clara. } 0 \text { conteúdo é abrangente, mas não faz uso de visualidade. }\end{array}$ & & & & \\
\hline \begin{tabular}{|l|l|l|l|l}
\end{tabular} & $\begin{array}{l}\text { Tabela com vagas de estágio. Cada i item é um fragmento de informação, sem uso de visualidade e sem valor estético. A apresentaçăo } \\
\text { não destaca pontos chave e é excessivamente linear. }\end{array}$ & & & & \\
\hline
\end{tabular}


O Estado de S. Paulo, 27/out./2009 (2ESP)

\begin{tabular}{|c|c|c|c|c|c|c|c|c|c|c|c|c|c|c|c|c|c|c|c|c|c|c|}
\hline digo & $\begin{array}{l}\text { ortagem } \\
\text { trogesming }\end{array}$ & $\begin{array}{l}\text { página } \\
\text { A4 }\end{array}$ & $\begin{array}{l}\text { editoria } \\
\text { Nacional }\end{array}$ & c & Ind/Sub & Esp/Enc & 11 & 12 & 13 & U1 & U2 & U3 & A1 & A2 & A3 & $\mathrm{C1}$ & $\mathrm{C2}$ & $\mathrm{C3}$ & 1 & 0 & A & c \\
\hline & 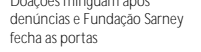 & & & & 2 & 3 & 2 & 3 & 2 & 3 & 3 & 3 & 3 & 3 & 2 & 3 & 3 & 3 & 7 & 9 & 8 & 9 \\
\hline ESPO02 & $\begin{array}{l}\text { Aliançade centro ameaca } \\
\text { vitóríd de Mujica no } 28 \text { turno } \\
\text { uruguauio }\end{array}$ & A10 & $\begin{array}{l}\substack{\text { Inter- } \\
\text { nacional }} \\
\text { nate }\end{array}$ & POL & 2 & 3 & 3 & 3 & 3 & 2 & 3 & 2 & 2 & 1 & 2 & 3 & 3 & 3 & 9 & 7 & 5 & 9 \\
\hline 2ESPO03 & $\begin{array}{l}\text { Quedas de heliçopteros matam } \\
14 \text { americanos }\end{array}$ & & $\begin{array}{l}\text { Inter. } \\
\text { nacional }\end{array}$ & GEC & 1 & 1 & 3 & 3 & 2 & 2 & 3 & 2 & 1 & 1 & 1 & 2 & 2 & 1 & 8 & 7 & 3 & 5 \\
\hline 2ESPO04 & $\begin{array}{l}\text { Sull-coreano écondenado por } \\
\text { frrude }\end{array}$ & A22 & Vidaá & CहT & 1 & 2 & 2 & 3 & 2 & 2 & 2 & 2 & 1 & 0 & 1 & 3 & 1 & 2 & 7 & 6 & 2 & 6 \\
\hline ESPO05 & $\begin{array}{l}\text { Reduçöo do I PI pode ser } \\
\text { permanente }\end{array}$ & B1,3 & Economia & ECN & 1 & 3 & 3 & 1 & 3 & 2 & 2 & 3 & 1 & 1 & 1 & 3 & 3 & 2 & 7 & 7 & 3 & 8 \\
\hline 2ESPO06 & Odolar, nos derivativos & B2 & Economia & ECN & 1 & 1 & 3 & 3 & 3 & 2 & 2 & 3 & 1 & 1 & 1 & 3 & 3 & 2 & 9 & 7 & 3 & 8 \\
\hline 2ESPO07 & $\begin{array}{l}\text { Confiancada indústriáéa } \\
\text { maior desce } 2005\end{array}$ & B3 & Economia & ECN & 1 & 3 & 3 & 2 & 3 & 2 & 3 & 2 & 1 & 1 & 1 & 3 & 3 & 2 & 8 & 7 & 3 & 8 \\
\hline 2ESP008 & $\begin{array}{l}\text { Bolsa descola de NY no final e } \\
\text { sobe }\end{array}$ & B9 & Economia & ECN & 1 & 3 & 3 & 1 & 3 & 2 & 3 & 2 & 1 & 1 & 1 & 2 & 3 & 1 & 7 & 7 & 3 & 6 \\
\hline 2ESPO09 & $\begin{array}{l}\text { ING vaid dividir negociose } \\
\text { vender sua arrea de seguros }\end{array}$ & 112 & Economia & ECN & 0 & 1 & 2 & 3 & 2 & 2 & 2 & 1 & 1 & 0 & 1 & 1 & 1 & 1 & 7 & 5 & 2 & 3 \\
\hline 2ESPO10 & 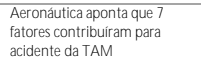 & $\mathrm{Cl}$ & Cidades & GEC & 2 & 3 & 2 & 1 & 1 & 2 & 2 & 3 & 3 & 3 & 2 & 3 & 3 & 3 & 4 & 7 & 8 & 9 \\
\hline 2EsP011 & $\begin{array}{l}\text { O melhor pastel de SP? } \\
\text { Pergunte para M Maria }\end{array}$ & c6 & Cidades & CID & 2 & 1 & 3 & 3 & 2 & 2 & 2 & 1 & 1 & 0 & 1 & 3 & 1 & 1 & 8 & 5 & 2 & 5 \\
\hline 2ESP012 & $\begin{array}{l}\text { concurso } \\
\text { odca }\end{array}$ & C6 & Cidades & CID & 1 & 1 & 3 & 3 & 2 & 2 & 2 & 1 & 1 & 0 & 1 & 2 & 1 & 1 & 8 & 5 & 2 & 4 \\
\hline 2ESP013 & $\begin{array}{l}\begin{array}{l}\text { Brevidade e bom humor à } \\
\text { brasileira }\end{array}\end{array}$ & D12 & Caderno2 & ENT & 1 & 1 & 3 & 2 & 2 & 2 & 2 & 2 & 1 & 1 & 1 & 2 & 1 & 1 & 7 & 6 & 3 & 4 \\
\hline ESP014 & $\begin{array}{l}\text { Uma semarn } \\
\text { nervos }\end{array}$ & $E 1,2$ & Esportes & ESP & 2 & 3 & 3 & 3 & 2 & 2 & 3 & 2 & 2 & 2 & 2 & 3 & 2 & 3 & 8 & 7 & 6 & 8 \\
\hline 2ESP015 & $\begin{array}{l}\text { Equipes mudam por um } \\
\text { objetivo: derrotar os os Lakers }\end{array}$ & E4 & Esportes & ESP & 2 & 3 & 2 & 3 & 3 & 2 & 2 & 3 & 3 & 3 & 2 & 3 & 3 & 3 & 8 & 7 & 8 & 9 \\
\hline 2ESP016 & llhas Virgens & $\mathrm{V} 1,6-10$ & $\begin{array}{l}\text { Viagem \& } \\
\text { Aventura }\end{array}$ & TUR & 2 & 3 & 2 & 2 & 3 & 2 & 3 & 3 & 2 & 2 & 2 & 3 & 2 & 3 & 7 & 8 & 6 & 8 \\
\hline 2ESP017 & Lembranças do paraiso & V45 & $\begin{array}{l}\text { Viagem \& } \\
\text { Aventura }\end{array}$ & TUR & 1 & 1 & 3 & 3 & 2 & 2 & 2 & 2 & 1 & 1 & 1 & 2 & 2 & 1 & 8 & 6 & 3 & 5 \\
\hline 2ESP018 & Muito além do livro didático & $10 \mathrm{E}$ & estadăo. EDU & EDU & 1 & 1 & 2 & 3 & 2 & 2 & 2 & 2 & 1 & 1 & 1 & 2 & 1 & 1 & 7 & 6 & 3 & 4 \\
\hline 2ESP019 & Pensando na escala internet & $12 E$ & estadăo. EDU & EDU & 2 & 2 & 1 & 3 & 3 & 3 & 3 & 3 & 2 & 3 & 3 & 3 & 3 & 3 & 7 & 9 & 8 & 9 \\
\hline 2ESPO2O & 0 maior vestibular do mundo & 14-17e & etadăáa. EDU & EDU & 0 & 1 & 2 & 3 & 2 & 2 & 2 & 1 & 1 & 0 & 1 & 2 & 1 & 1 & 7 & 5 & 2 & 4 \\
\hline 2ESP021 & Prioridade número 1 & $18,20 \mathrm{E}$ & estadăo. EDU & EDU & 0 & 1 & 1 & 3 & 2 & 2 & 2 & 3 & 1 & 0 & 1 & 2 & 1 & 1 & 6 & 7 & 2 & 4 \\
\hline 2ESPO22 & Olho em bilogia e geografia & 22-23E & estadáa. EDU & EDU & 2 & 3 & 3 & 2 & 1 & 2 & 3 & 2 & 2 & 2 & 2 & 3 & 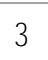 & 2 & 6 & 7 & 6 & 8 \\
\hline 2ESPO23 & Estudo relax & $24 \mathrm{E}$ & etadadó. EDU & EDU & 3 & 1 & 3 & 3 & 2 & 2 & 2 & 3 & 1 & 1 & 1 & 3 & 1 & 3 & 8 & 7 & 3 & 7 \\
\hline 2ESPO24 & Raio $X$ & $26 \mathrm{E}$ & etadadón. EDU & EDU & 2 & 1 & 3 & 3 & 2 & 2 & 2 & 2 & 1 & 0 & 1 & 3 & 1 & 1 & 8 & 6 & 2 & 5 \\
\hline 2ESPO25 & 7 pecadosd & $28,30 \mathrm{E}$ & estadăo. EDU & EDU & 2 & 3 & 3 & 3 & 2 & 2 & 2 & 3 & 3 & 2 & 1 & 3 & 1 & 3 & 8 & 7 & 6 & 7 \\
\hline 2ESPO26 & SOS animal & 32-33E & $\begin{array}{l}\text { estadăo } \\
. E D U\end{array}$ & EDU & 1 & 1 & 2 & 3 & 2 & 2 & 2 & 3 & 3 & 3 & 2 & 2 & 1 & 2 & 7 & 7 & 8 & 5 \\
\hline & & & & & 36 & 30 & & & & & & 29 & & & & & & 50 & 91 & $1 / 4$ & 110 & 67 \\
\hline
\end{tabular}

$\begin{array}{llllllllllllllllll}1,385 & 1,923 & 2,5 & 2,615 & 2,231 & 2,077 & 2,346 & 2,269 & 1,577 & 1,269 & 1,385 & 2,577 & 1,923 & 1,923 & 7,346 & 6,692 & 4,231 & 6,423\end{array}$ 


\begin{tabular}{|c|c|c|c|c|c|}
\hline \multirow{2}{*}{$\begin{array}{l}\text { Código } \\
\text { 2ESP001 }\end{array}$} & \multirow{2}{*}{$\begin{array}{l}\text { Comentários } \\
\text { Conjunto visual marcante, com bom uso de cores e iconografia parat transmitir e gravar informaçōes. } 0 \text { conteúdo é bastante } \\
\text { completo e forma uma narrativa estruturada. }\end{array}$} & & & \multirow[b]{2}{*}{8} & \multirow[b]{2}{*}{9} \\
\hline & & 7 & 9 & & \\
\hline 2ESP002 & $\begin{array}{l}\text { Contéd́do adequado (resultado de eleiçöes) e explorando representaçăo visual de dados quantitativos. Há algumas falhas na } \\
\text { representacăo (uores muito parecidas; o vermelho do partido colorado destaca uma informaçăo menos importante; a organizaçăo de } \\
\text { bolinhas dificulta a comparaçăo). }\end{array}$ & 9 & 7 & 5 & 9 \\
\hline 2ESP003 & $\begin{array}{l}\text { Contéd́do raso, apenas localizando as quedas noticiadas. A notaçäo no mapa é éficaz, indicando fronteiras, a capital e destacando os } \\
\text { locais das quedas. }\end{array}$ & 8 & 7 & J & 5 \\
\hline 2ESP004 & Narrativa pouco visual e essencialmente textual, mas com conteúdo competente (resume eventos que levaram ao fato noticiado). & 7 & 6 & 2 & 6 \\
\hline 2ESP005 & $\begin{array}{l}\text { Gráfico de barras pequeno e de baixo impacto visual, mas com uso adequado da representaçẵo gráfica e boa seleção de dados para a } \\
\text { cobertura. A comparaçăo exige atençấo porque cada categoria teve periodo differente de vigência }\end{array}$ & 7 & 7 & 3 & 8 \\
\hline 2ESP006 & 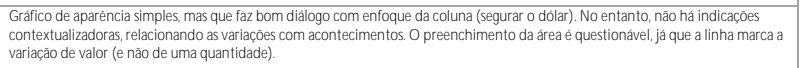 & 9 & 7 & 3 & 8 \\
\hline 2ESP007 & $\begin{array}{l}\text { Bom contéúdo, embora não mostre todo o perído citado no título da reportagem. } 0 \text { uso de cores facilita a leitura e os dados estăo } \\
\text { bem organizados, mas os grráficos de barra lado a lado esconde um pouco a "evoluçâao". }\end{array}$ & 8 & 7 & 3 & 8 \\
\hline 2ESP008 & $\begin{array}{l}\text { Conteúdo bastante especifico, mostrando apenas um ponto da reportagem. Pode haver confusão com o tipo de representaçăo, que } \\
\text { privilegia a comparaça̧o devariaçăo (mas valores bastante diferentes, atée mesmo com moedas difierentes). }\end{array}$ & 7 & 7 & 3 & 6 \\
\hline 2ESP009 & Conteúdo limitado e apresentado de maneira pouco interessante. Os valores năo săo mostrados graficamente ou contextualizados. & 7 & 5 & 2 & 3 \\
\hline 2ESP010 & 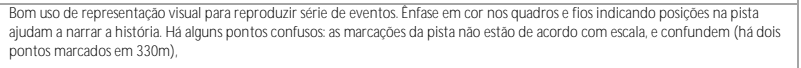 & 4 & 7 & 8 & 9 \\
\hline 2ESP011 & Sumário traz informação prática e de forma textual, sem uso de cores, iconografia ou representaçẵo graf́ica. & 8 & 5 & 2 & 5 \\
\hline 2ESP012 & 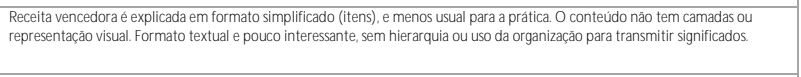 & 8 & 5 & 2 & 4 \\
\hline 2ESP013 & $\begin{array}{l}\text { Excertos do livro complementam a reportagem, mas sem o ângulo didático e analítico. Formato textual com baixo valor estético ou } \\
\text { de representaçăo de informaçấ. }\end{array}$ & 7 & 6 & 3 & 4 \\
\hline 2ESP014 & Quadro rico em informaçöes e com bom aproveitamente de recursoso gráficos. & 8 & 7 & 6 & 8 \\
\hline 2ESP015 & Conteúdo completo (temporada anterior e geral), facilitando comparaçōes e análises tanto dos times como dos jogadores. & 8 & 7 & 8 & 9 \\
\hline 2ESP016 & 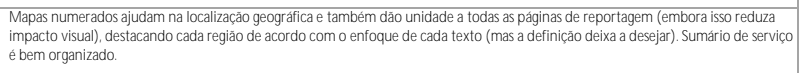 & 7 & 8 & 6 & 8 \\
\hline 2ESP017 & Quadro de serviços, com conteúdo sem aprofundamento. 0 mapa, pequeno, tem notaçōes fracas e confusas. & 8 & 6 & 3 & 5 \\
\hline 2ESP018 & $\begin{array}{l}\text { Pequeno e de importância reduzida; contéúdo falho por não identificar os sites (há apenas a URL, nä̃o os autores ou o tipo de } \\
\text { conteúdo). Organizaçăo simples limita valor de cada seçấo. }\end{array}$ & 7 & 6 & 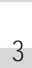 & 4 \\
\hline 2ESP019 & 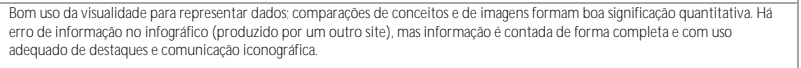 & 7 & 9 & 8 & 9 \\
\hline 2ESP020 & 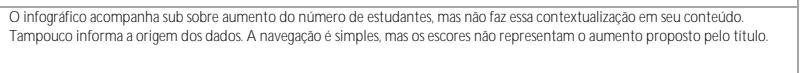 & 7 & 5 & 2 & 4 \\
\hline 2ESP021 & 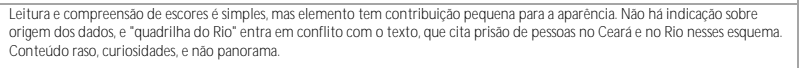 & 6 & 7 & 2 & 4 \\
\hline 2ESP022 & 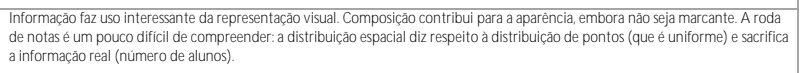 & 6 & 7 & 6 & 8 \\
\hline 2 2ESP023 & $\begin{array}{l}0 \text { contédódo é adequado porque relaciona sinopse e motivo, identificando também a capa a de cada filme. } 0 \text { valor estético ébaixo por } \\
\text { ser muito textual e usar imagens pequenase pouco marcantes. A navegaçăo éfácil, mas sem hierarquuia. }\end{array}$ & 8 & 7 & o & 7 \\
\hline 2ESP024 & $\begin{array}{l}\text { Conteúdo bastante completo e informativo, mas com uso limitado da visualidade. Recursos gráficos fracos. A navegação é simples, } \\
\text { mas sem hierarquia ou destaques. A organização tampouco reforça a questão cronológica. }\end{array}$ & 8 & 6 & 2 & 5 \\
\hline 2ESP025 & $\begin{array}{l}\text { Háindicaçăo de crédito e comentários contextualizando as informaç̧öes. Cada número traz exemplo adequado. Formato cria } \\
\text { interesse, embora seja bastante textual. }\end{array}$ & 8 & 7 & 6 & 7 \\
\hline 2ESP026 & $\begin{array}{l}\text { O contéúdo deixa a desejar porque o elemento mais significativo (ilustraçöes de animais) se distancia da novidade da reportagem. } \\
\text { Mas há grande valor estetico (embora um pouco fragnentada). } 0 \text { passo-apasso do procedimento é organizado e ilustrado de forma } \\
\text { adequada. }\end{array}$ & 7 & 7 & 8 & 5 \\
\hline
\end{tabular}


O Estado de S. Paulo, 23/abr./2010 (3ESP)

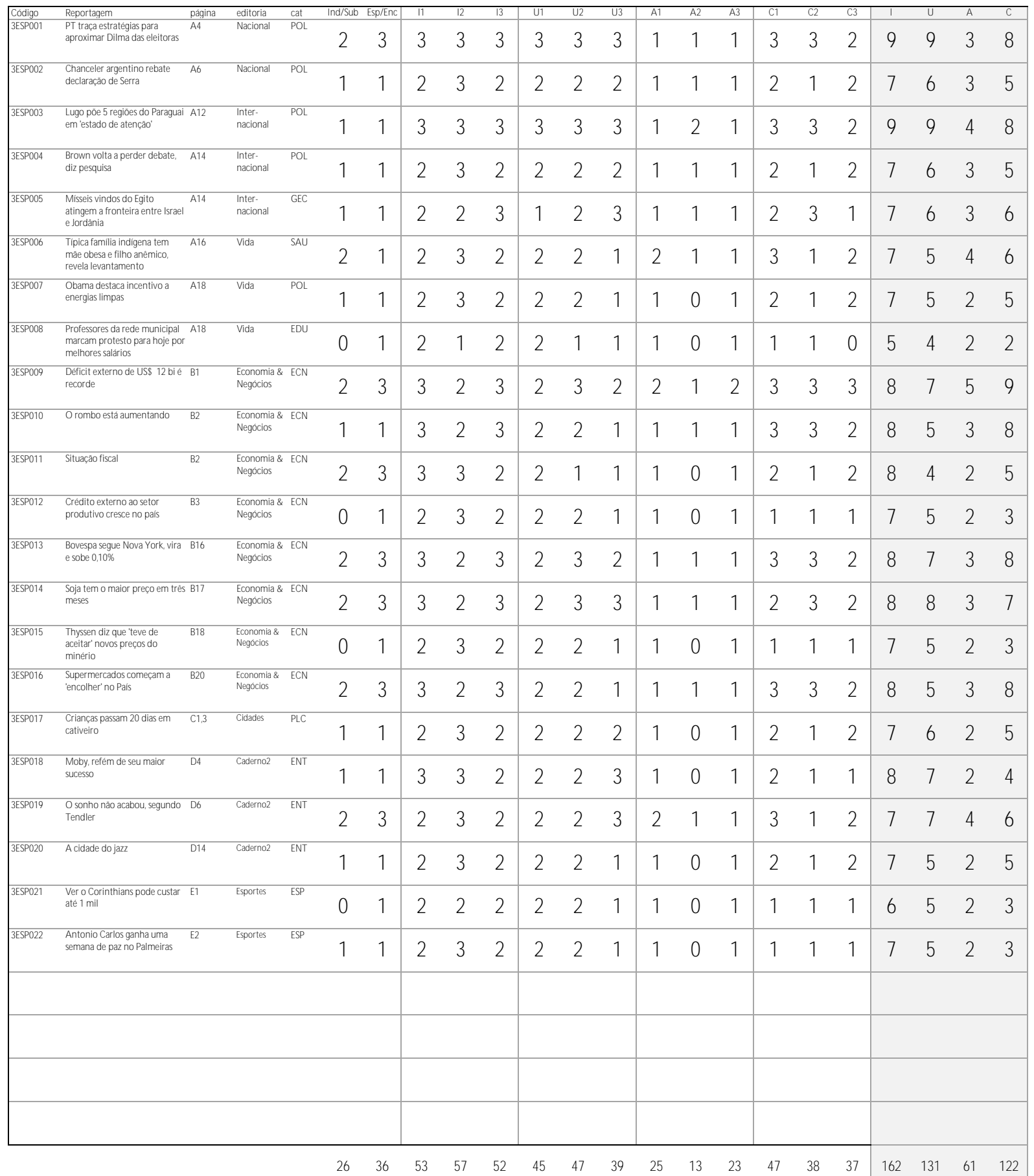

$\begin{array}{llllllllllllllllll}1,182 & 1,636 & 2,409 & 2,591 & 2,364 & 2,045 & 2,136 & 1,773 & 1,136 & 0,591 & 1,045 & 2,136 & 1,727 & 1,682 & 7,364 & 5,955 & 2,773 & 5,545\end{array}$ 


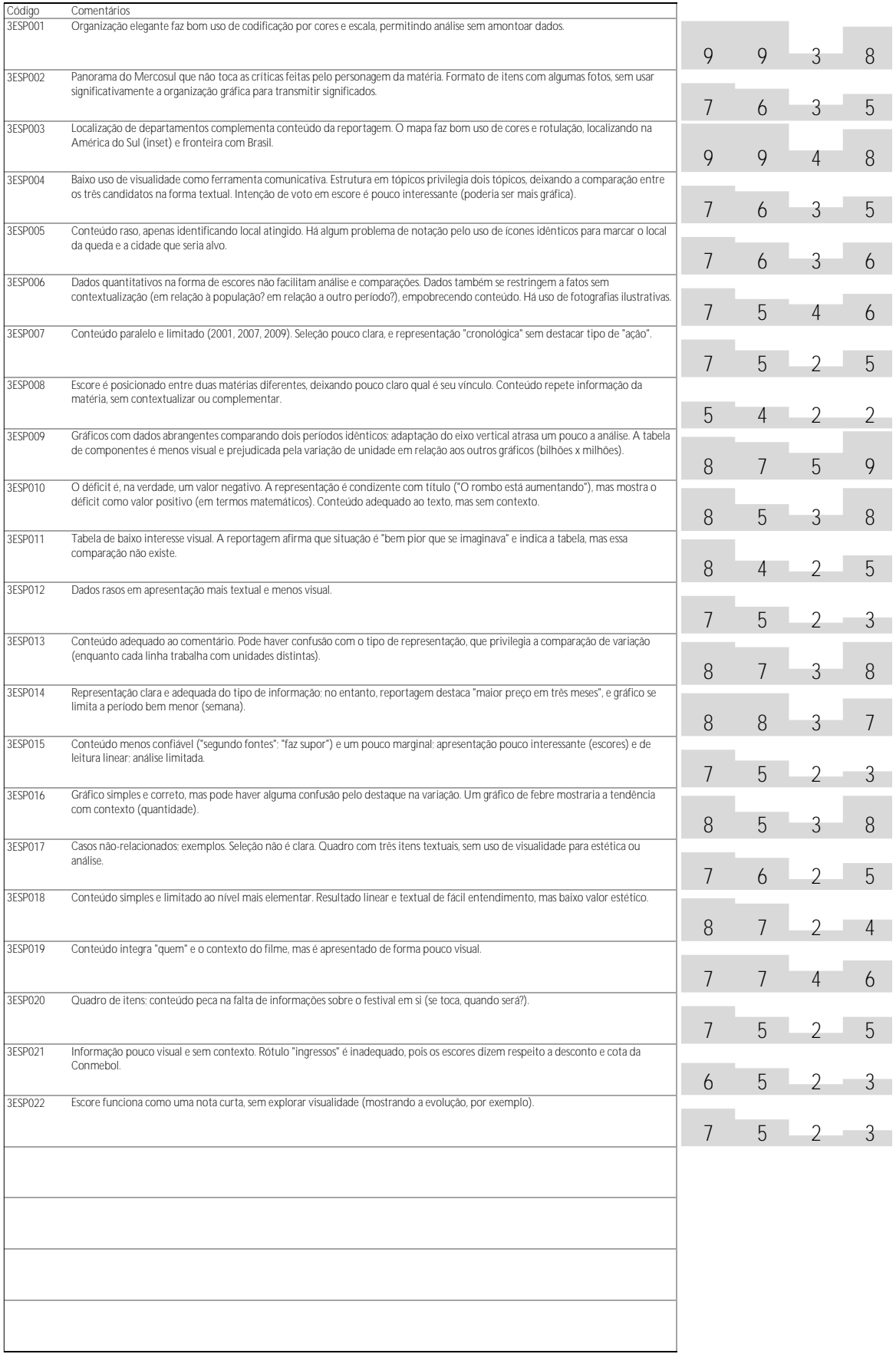


Folha de S. Paulo, 19/abr./2009 (1FSP)

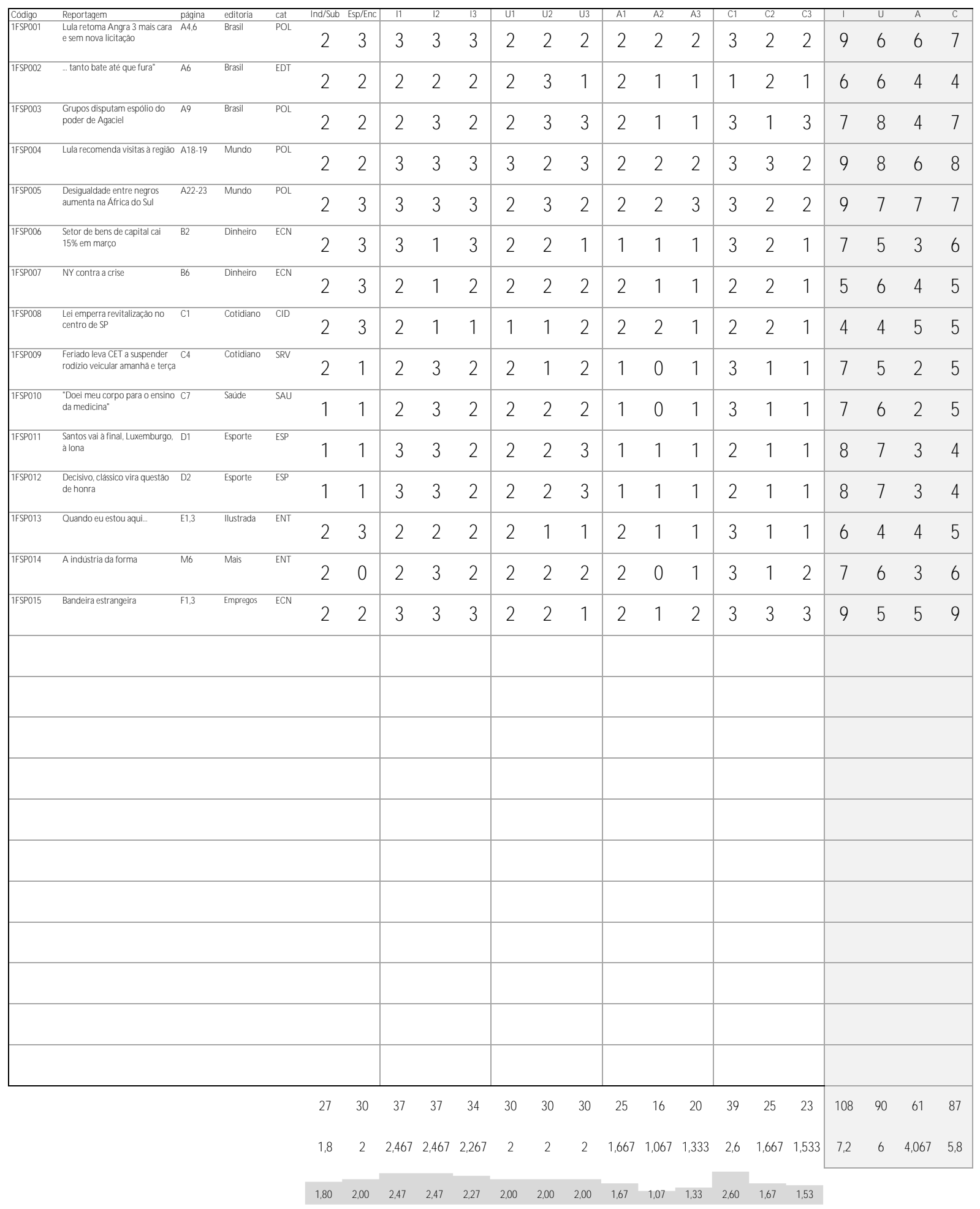




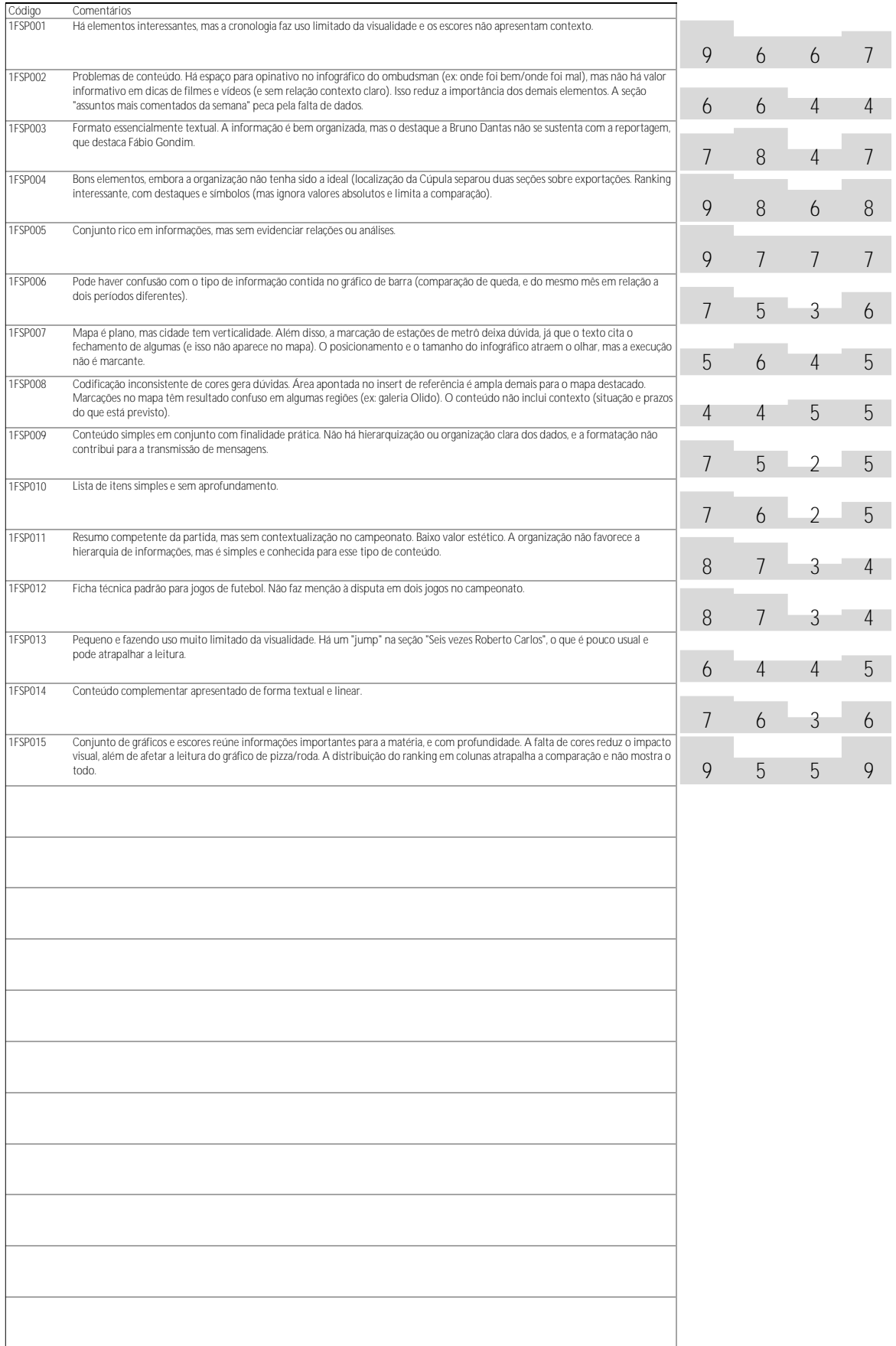


Folha de S. Paulo, 27/out./2009 (2FSP)

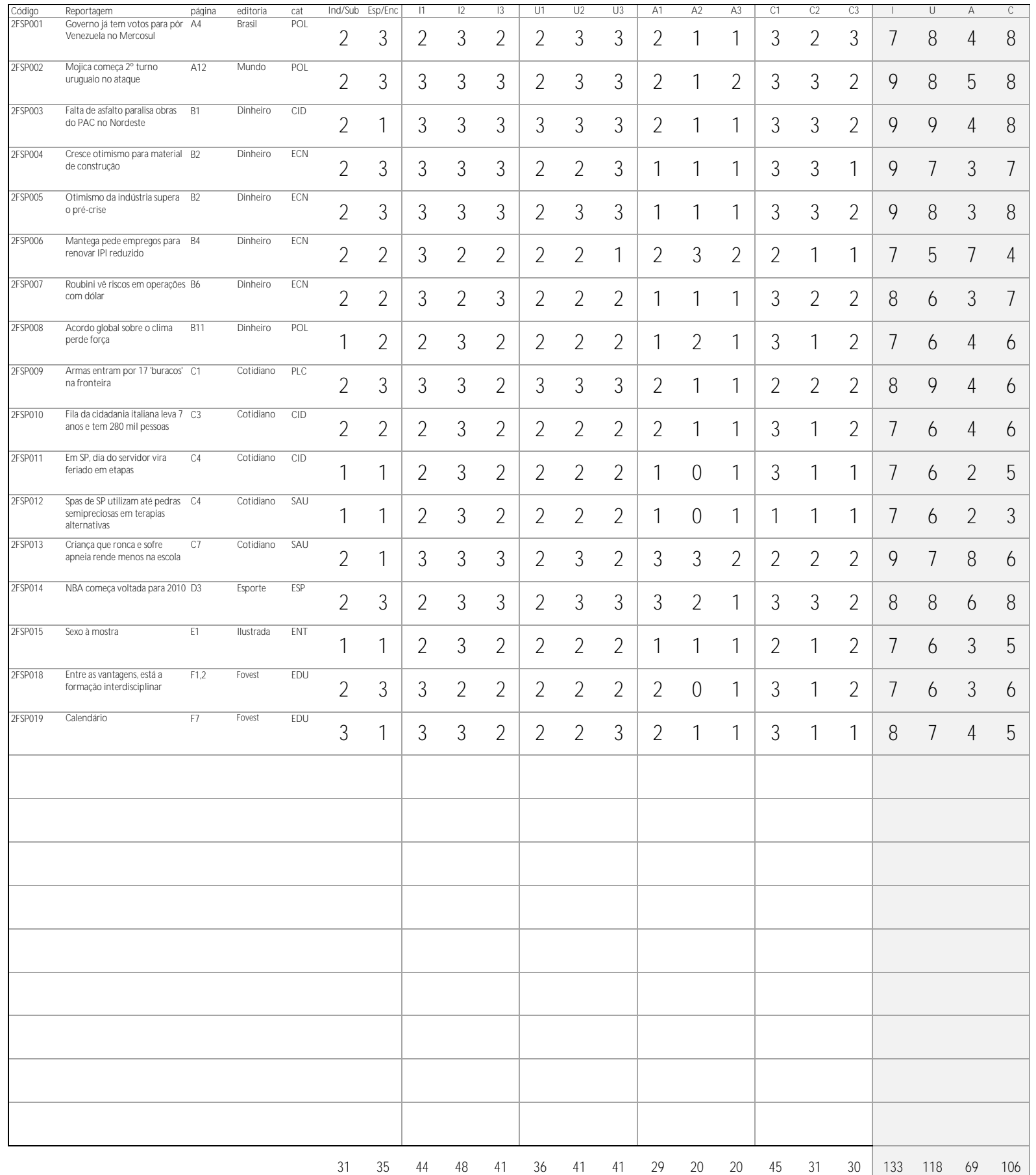

$\begin{array}{llllllllllllllllll}1,632 & 1,842 & 2,316 & 2,526 & 2,158 & 1,895 & 2,158 & 2,158 & 1,526 & 1,053 & 1,053 & 2,368 & 1,632 & 1,579 & 7 & 6,211 & 3,632 & 5,579\end{array}$ 


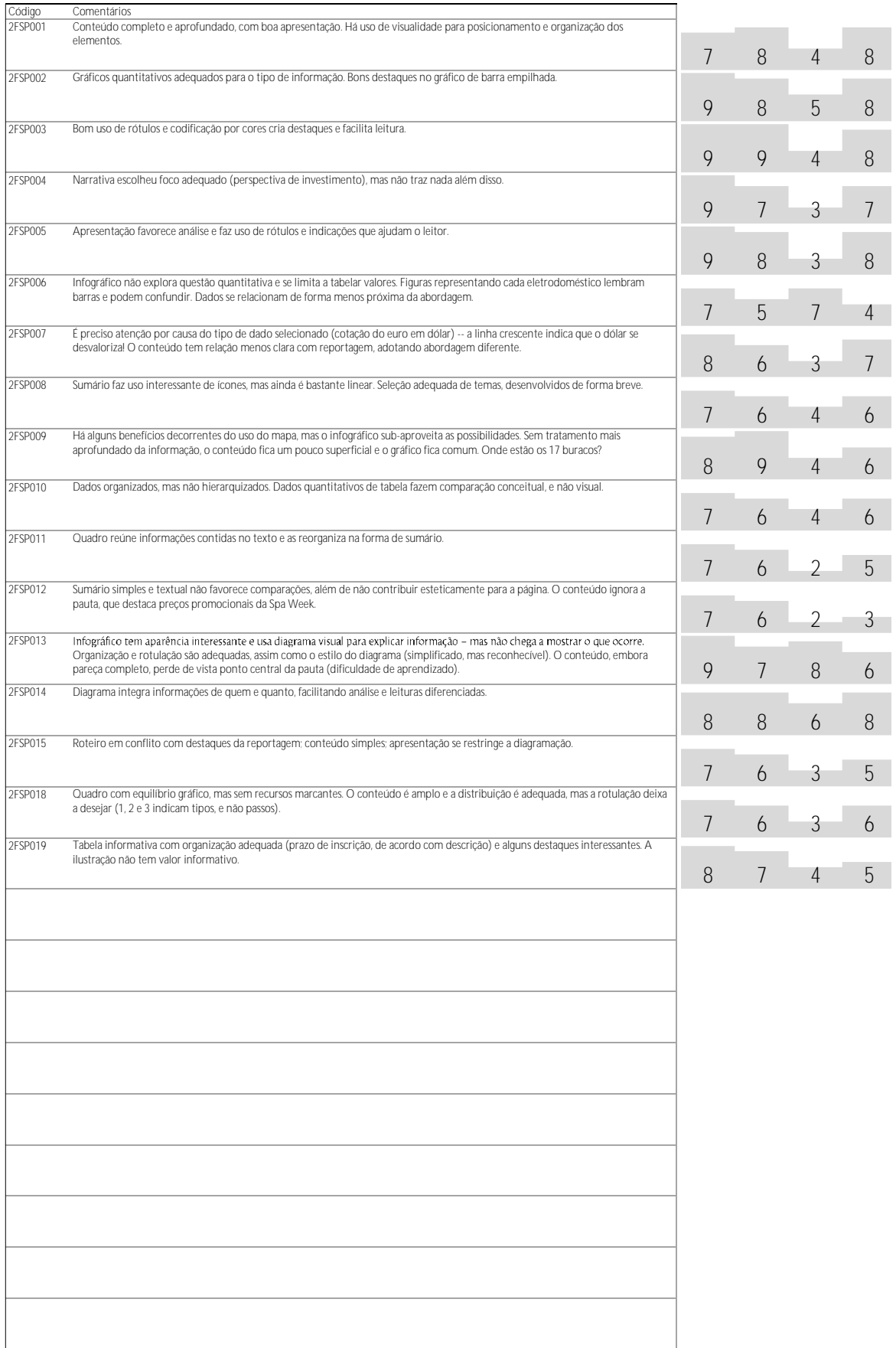


Folha de S. Paulo, 23/abr./2010 (3FSP)

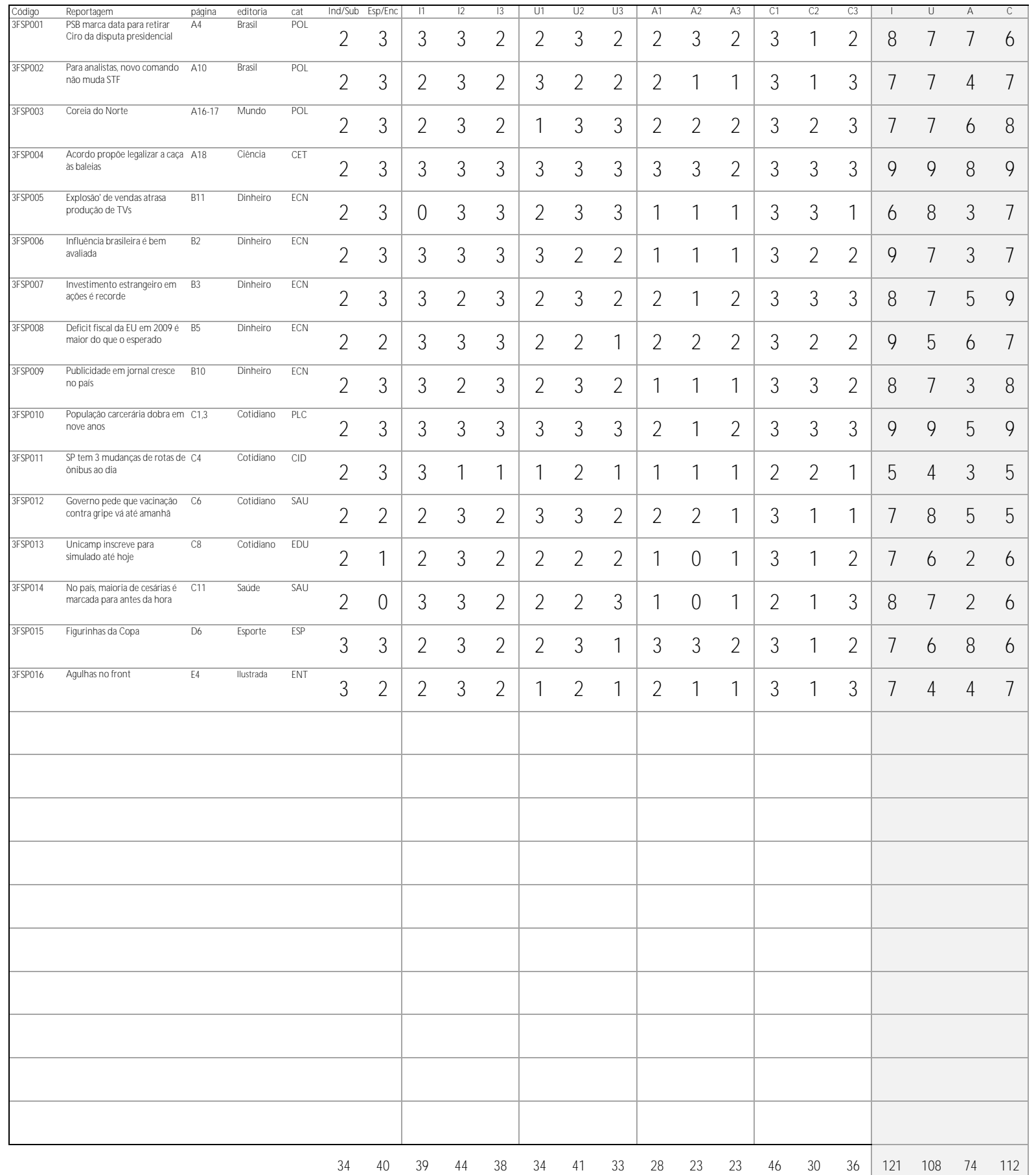

$\begin{array}{llllllllllllllllll}2,125 & 2,5 & 2,438 & 2,75 & 2,375 & 2,125 & 2,563 & 2,063 & 1,75 & 1,438 & 1,438 & 2,875 & 1,875 & 2,25 & 7,563 & 6,75 & 4,625 & 7\end{array}$ 


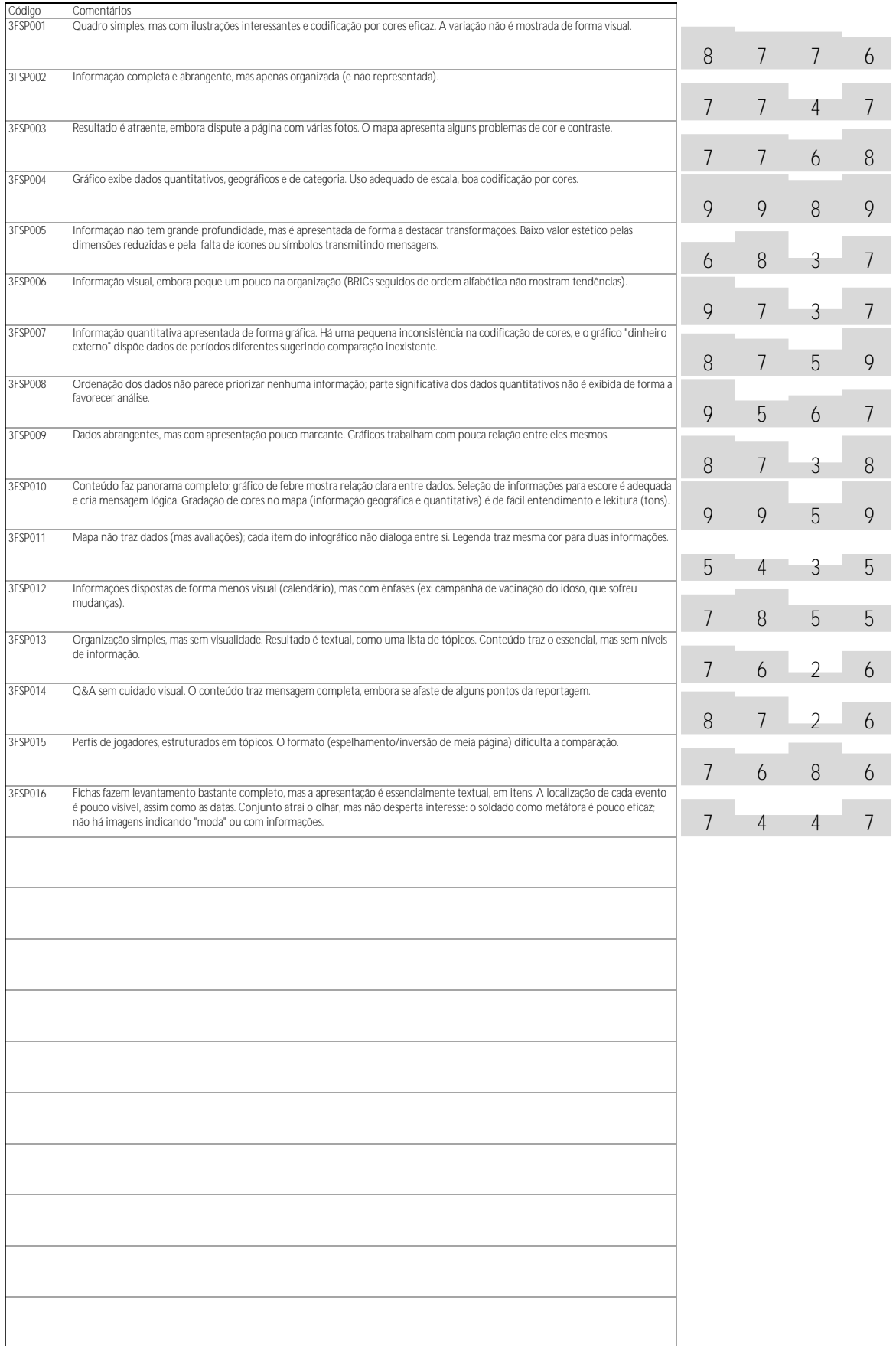


Jornal da Tarde, 19/abr./2009 (1JTD)

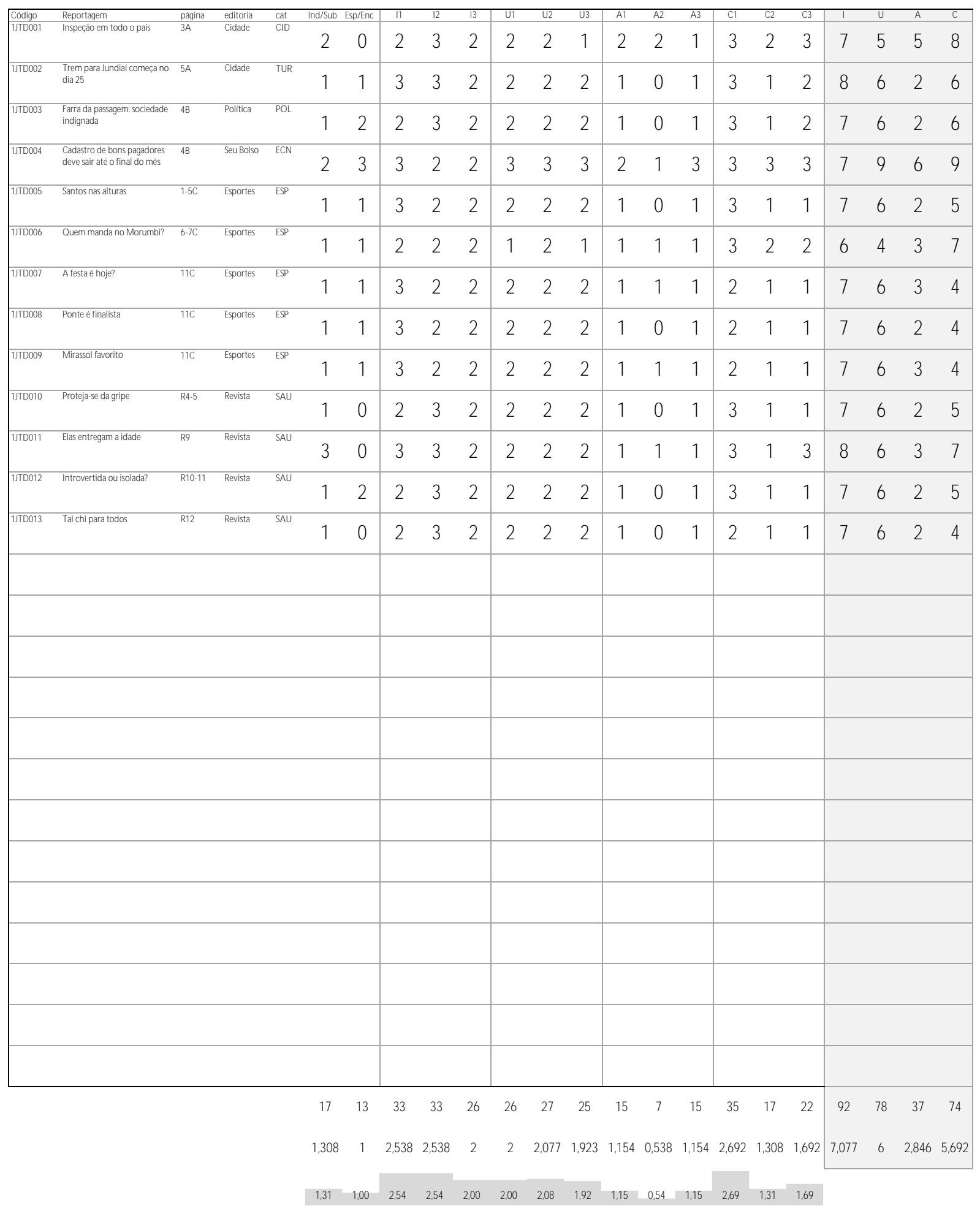




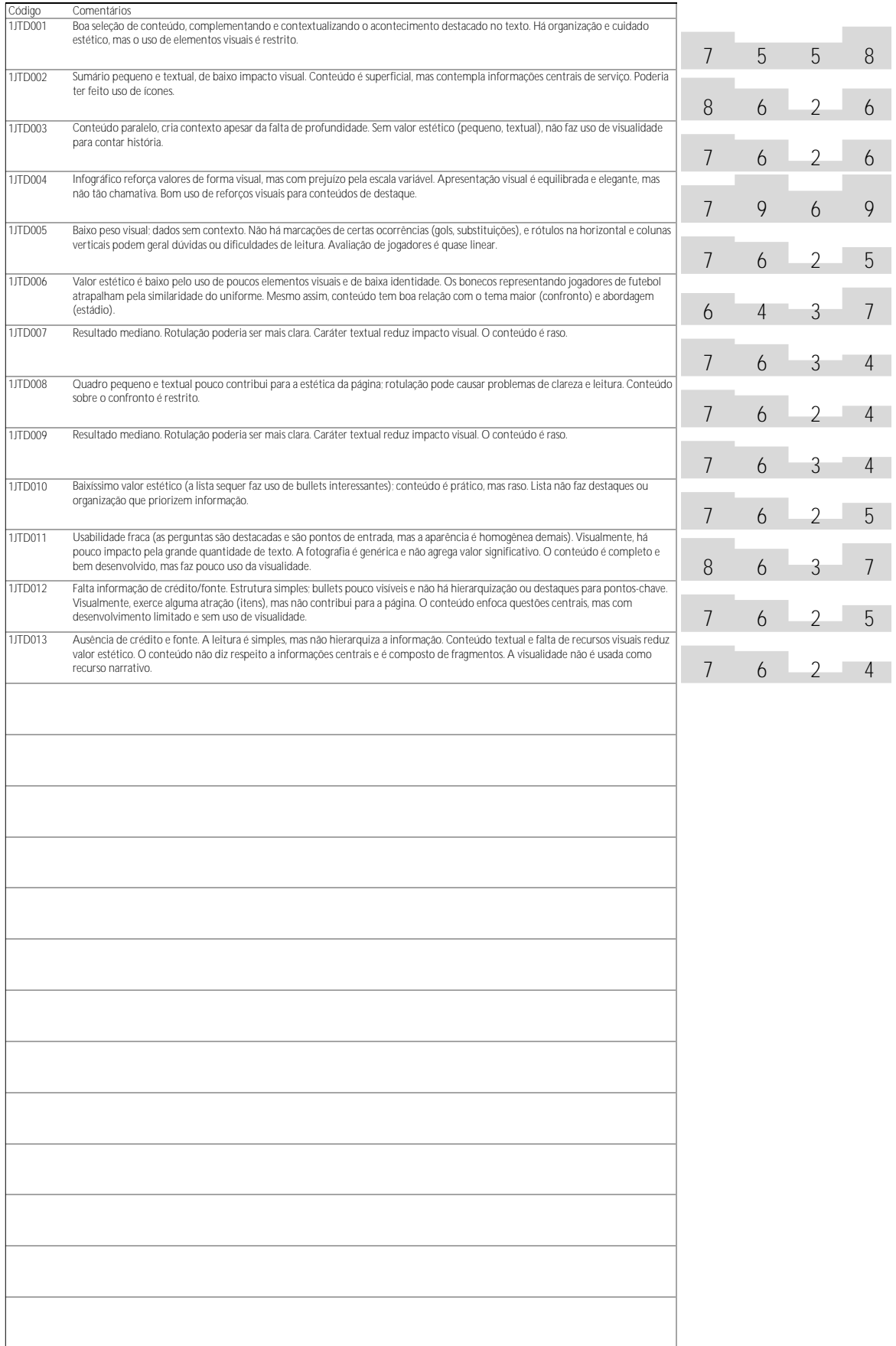


Jornal da Tarde, 27/out./2009 (2JTD)

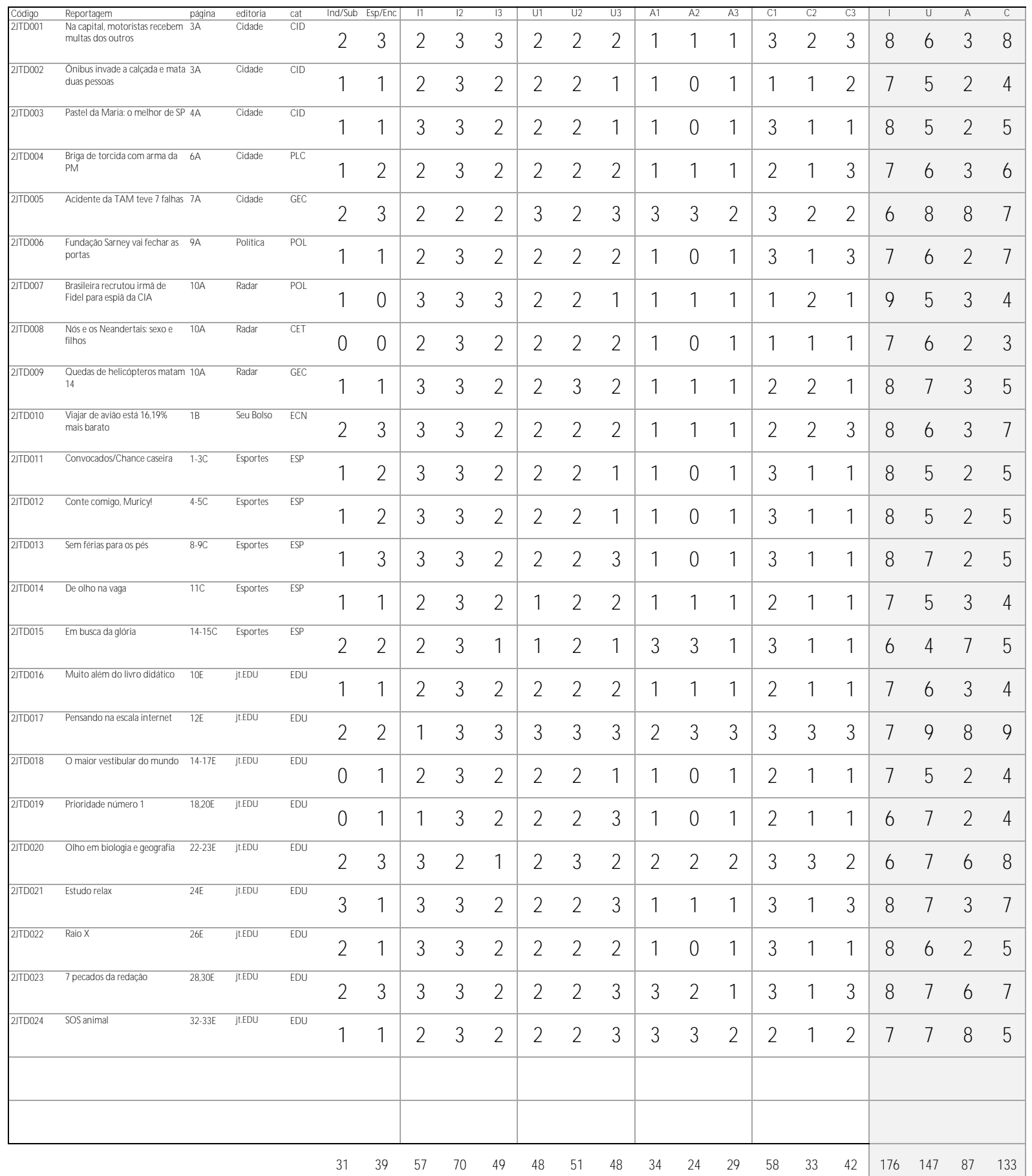

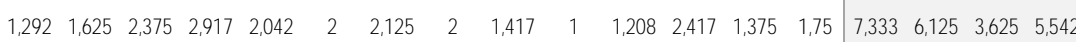




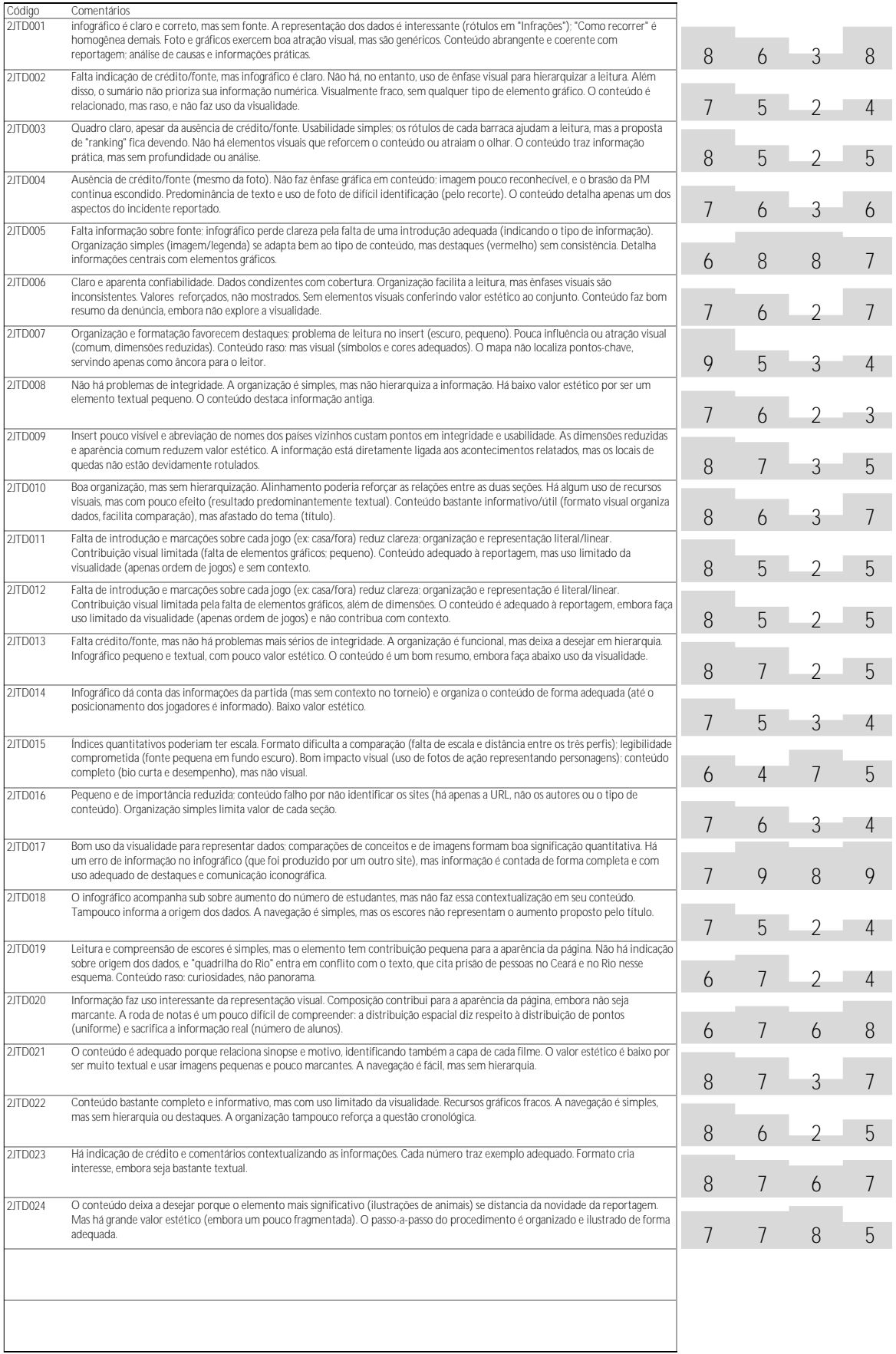


Jornal da Tarde, 23/abr./2010 (3JTD)

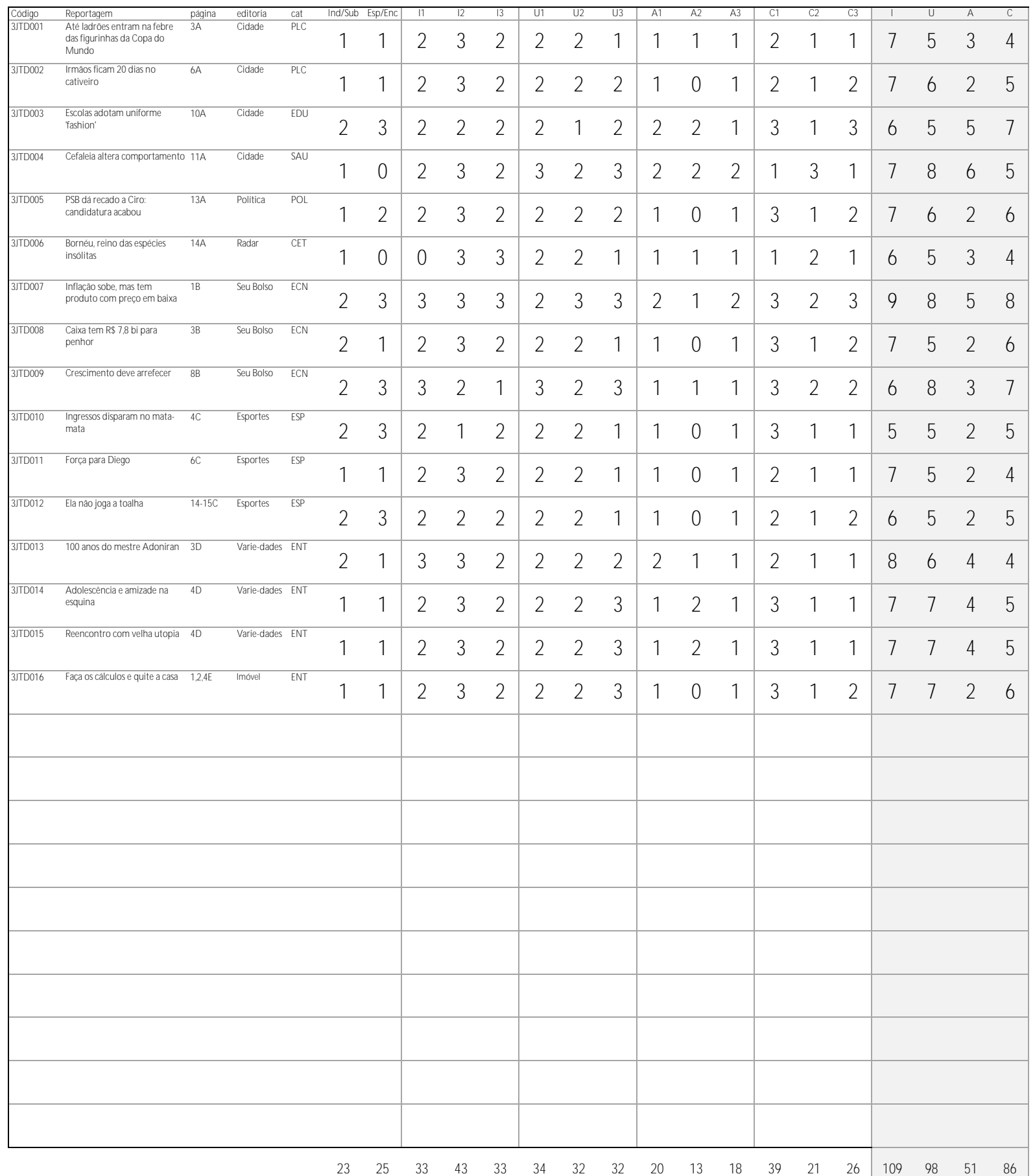

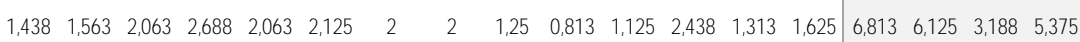




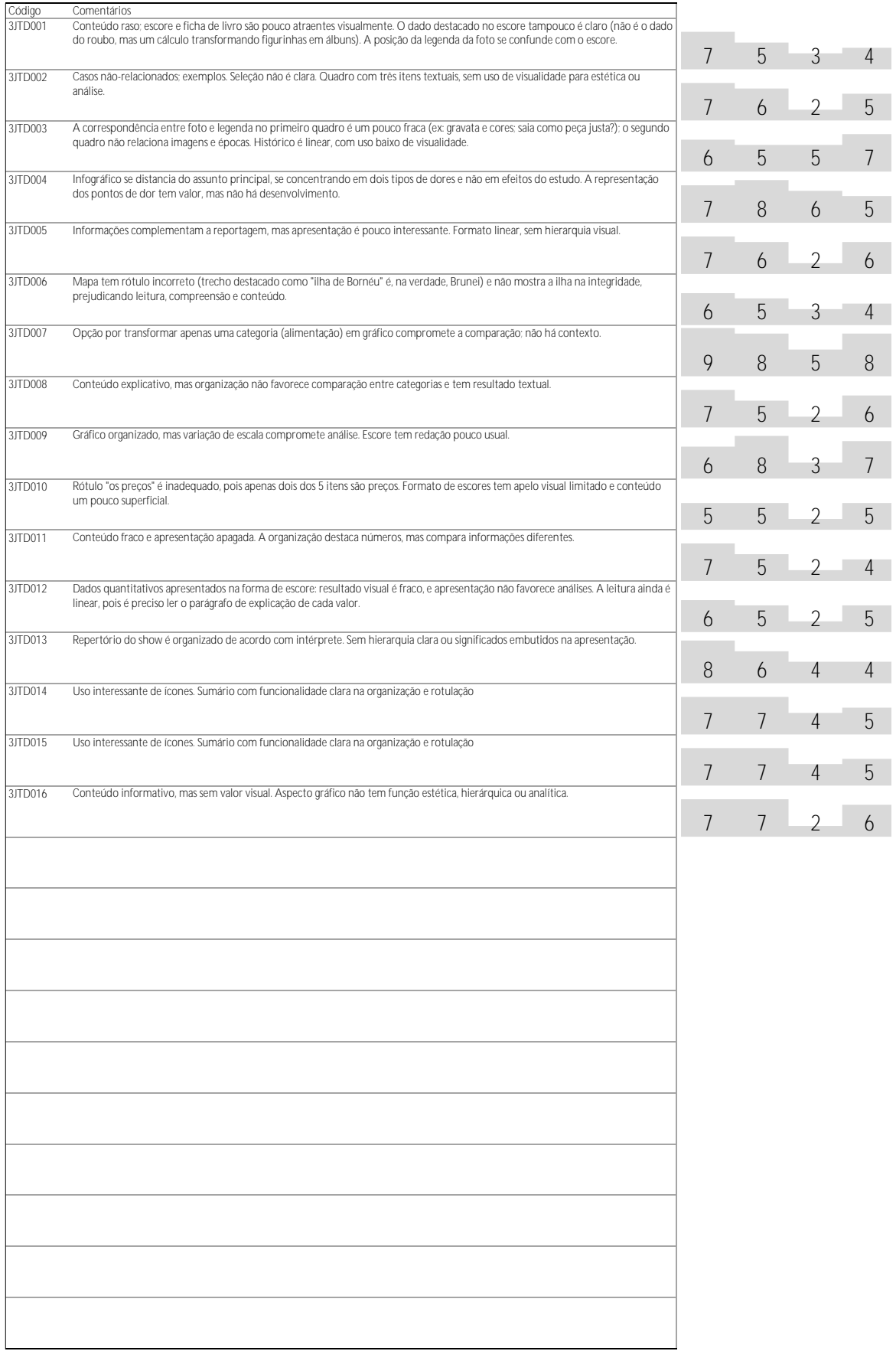


Época, 20/abr./2009 (1EPC)

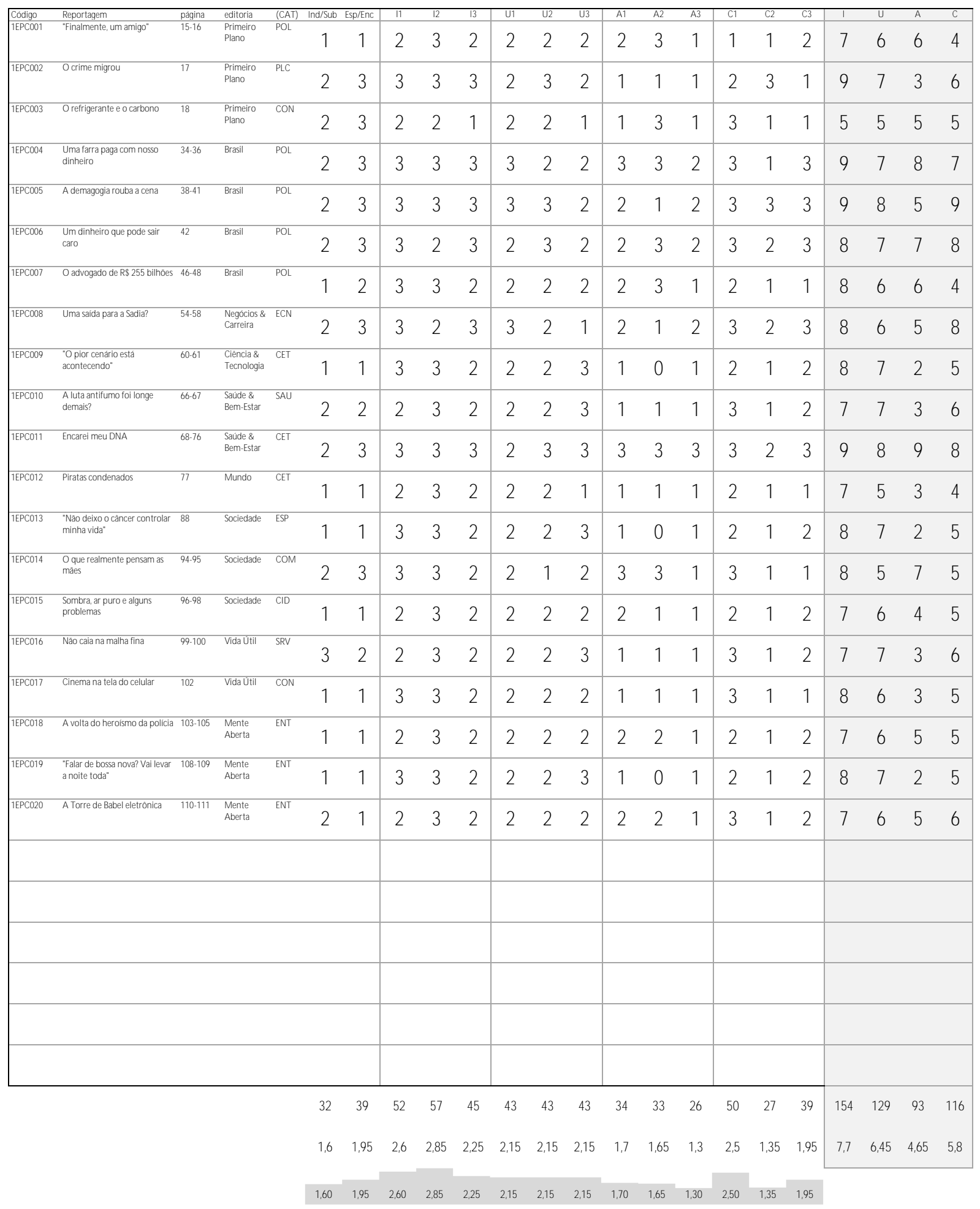




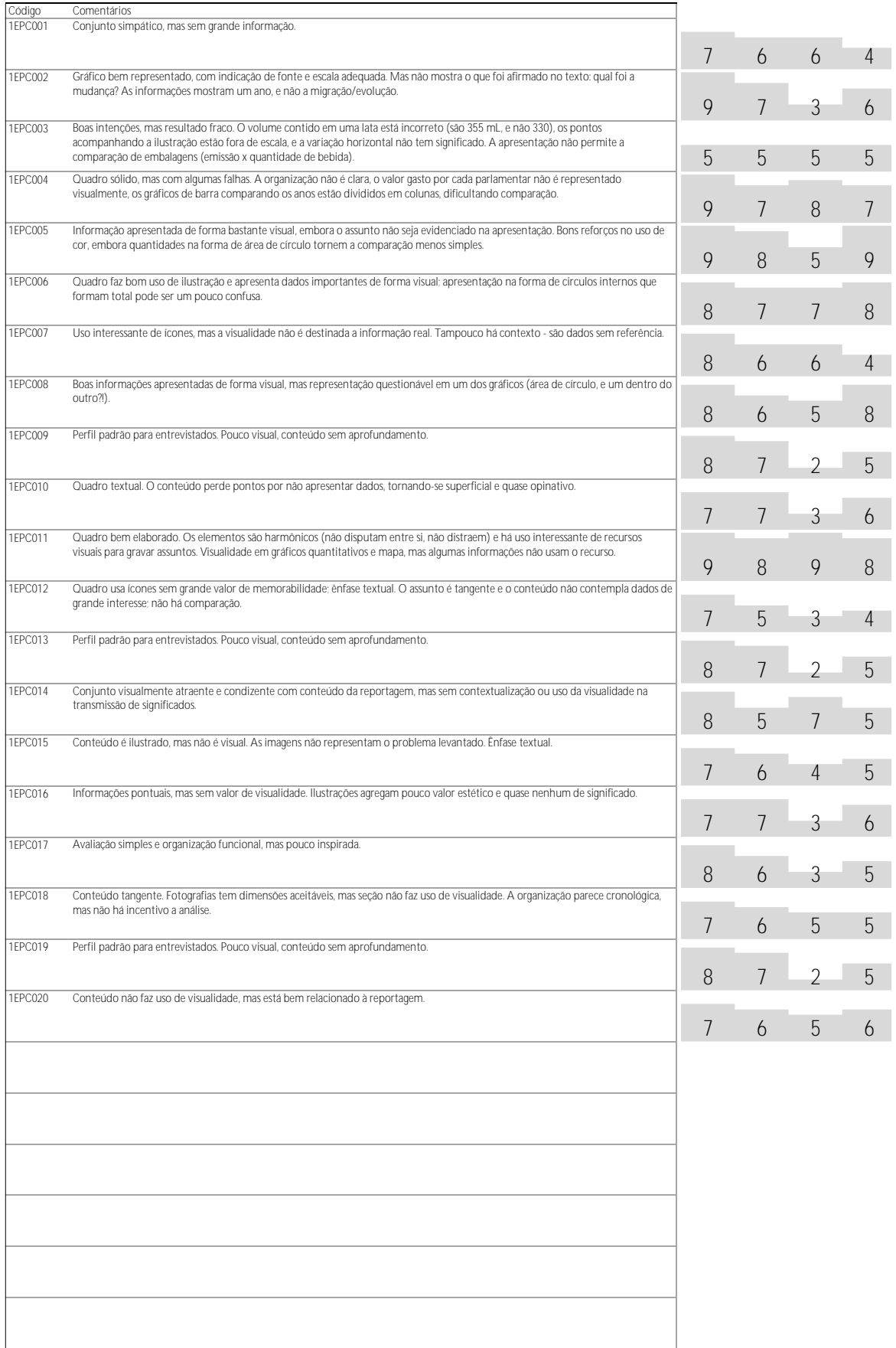


Época, 26/out./2009 (2EPC)

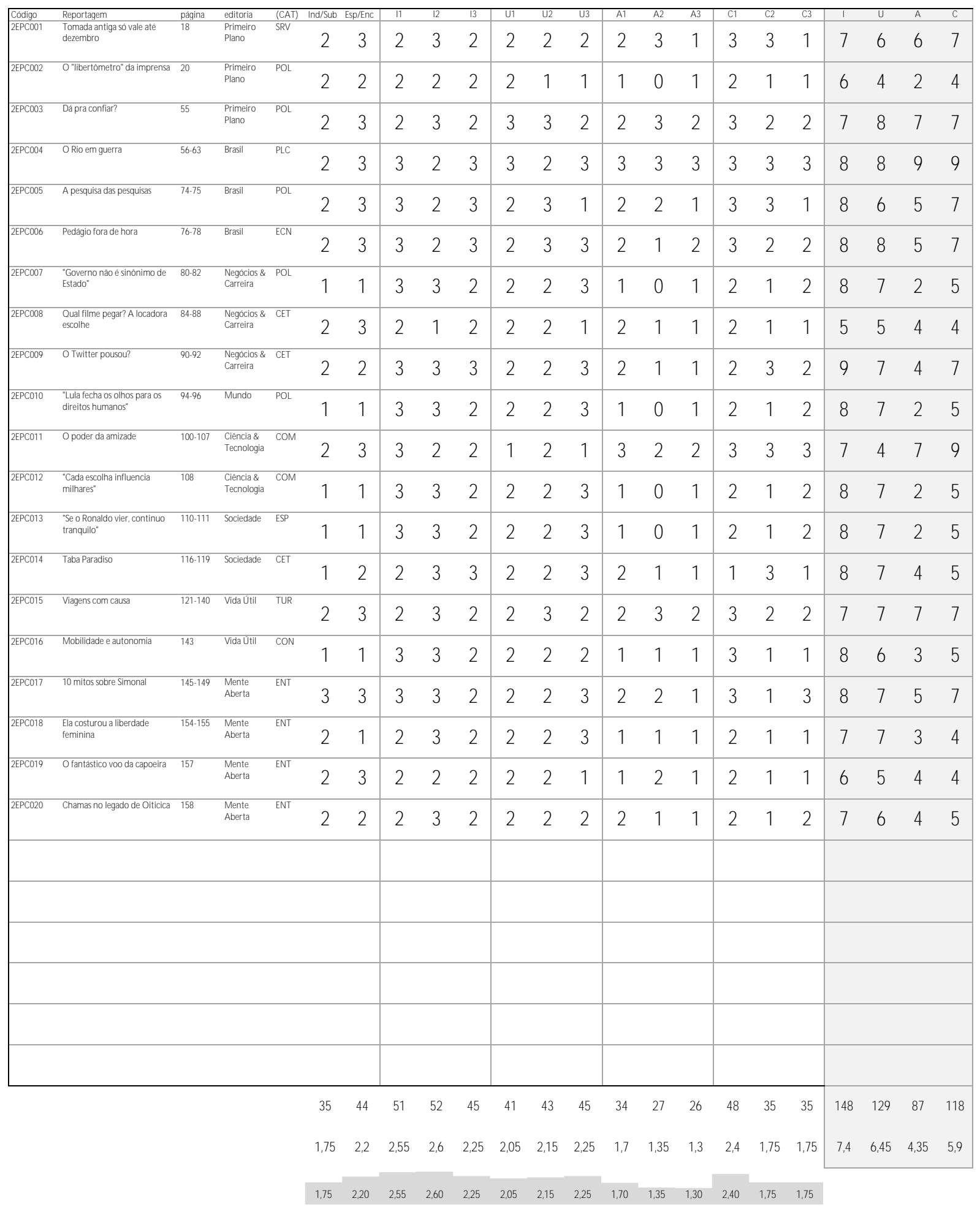




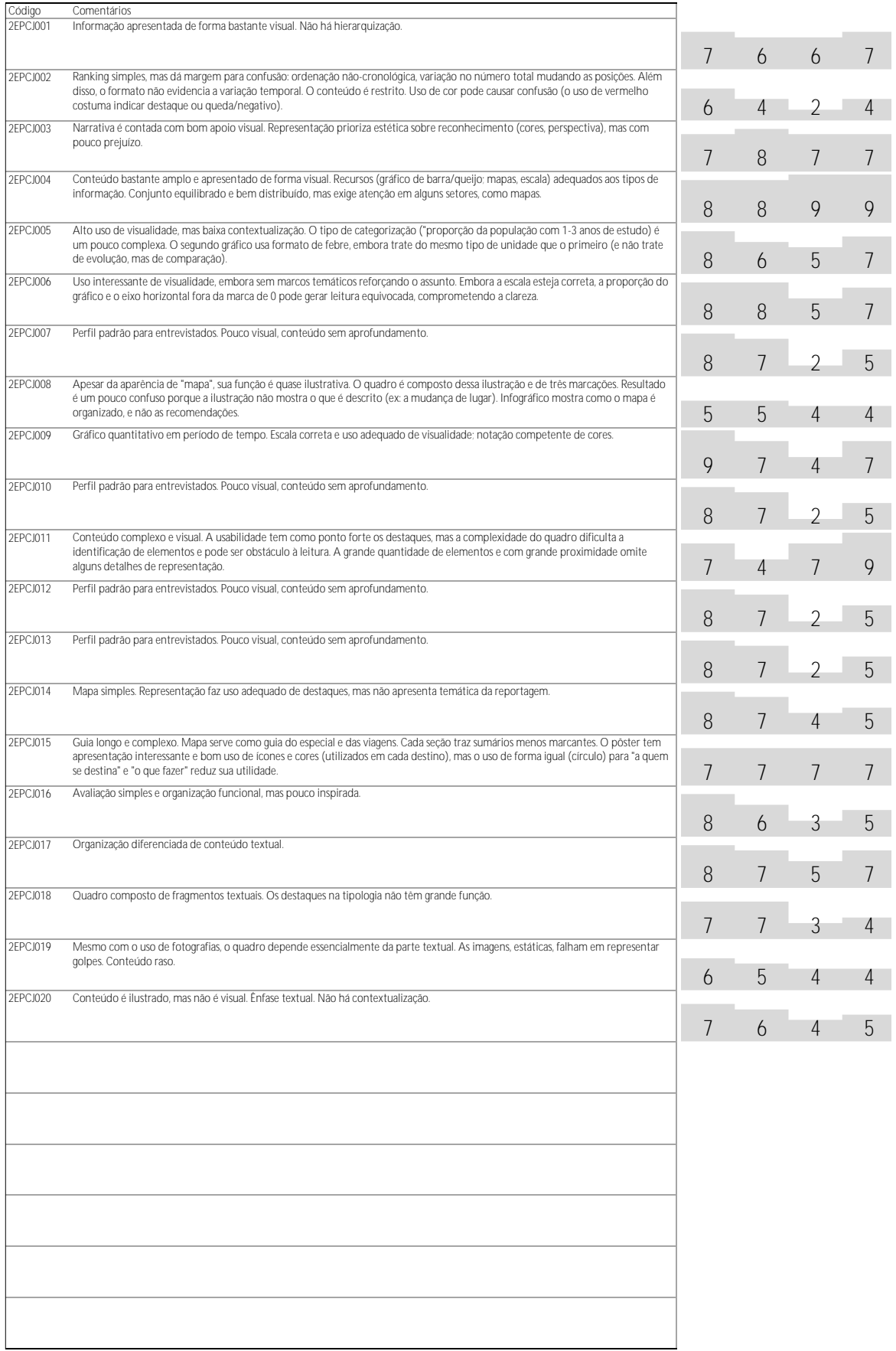


Época, 19/abr./2010 (3EPC)

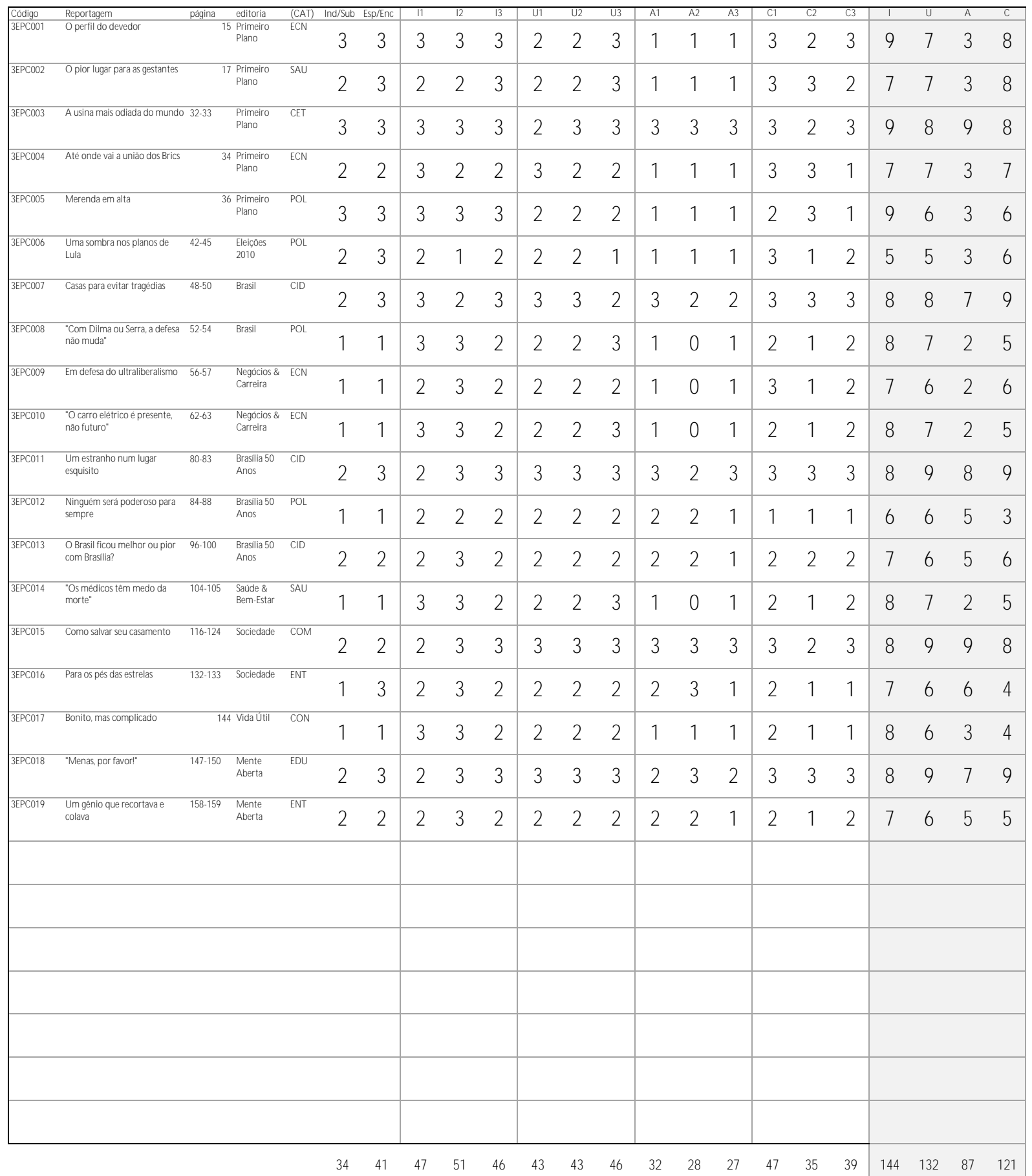

$\begin{array}{llllllllllllllllll}1,789 & 2,158 & 2,474 & 2,684 & 2,421 & 2,263 & 2,263 & 2,421 & 1,684 & 1,474 & 1,421 & 2,474 & 1,842 & 2,053 & 7,579 & 6,947 & 4,579 & 6,368\end{array}$ 


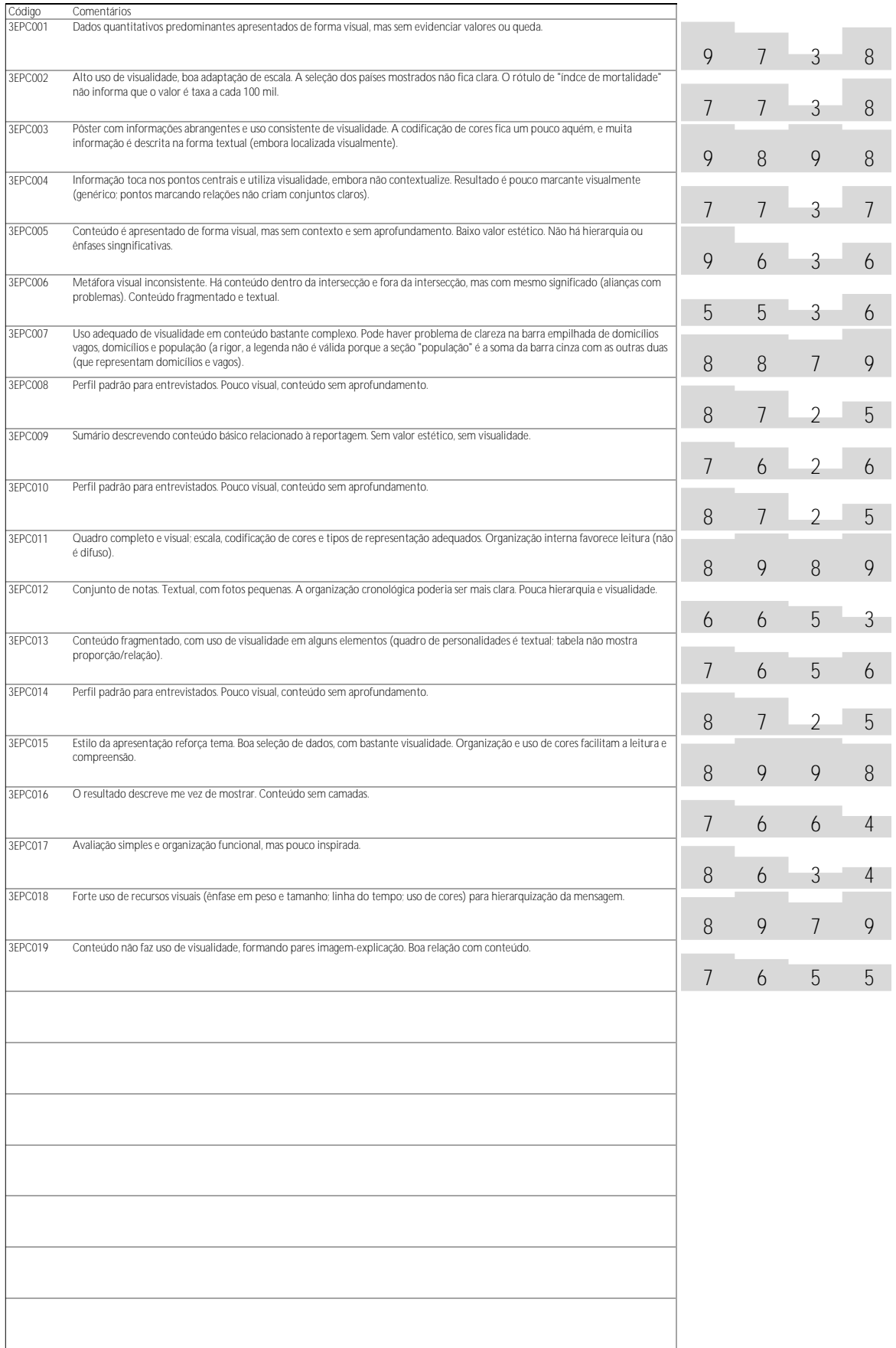


Veja, 22/abr./2009 (1VEJ)

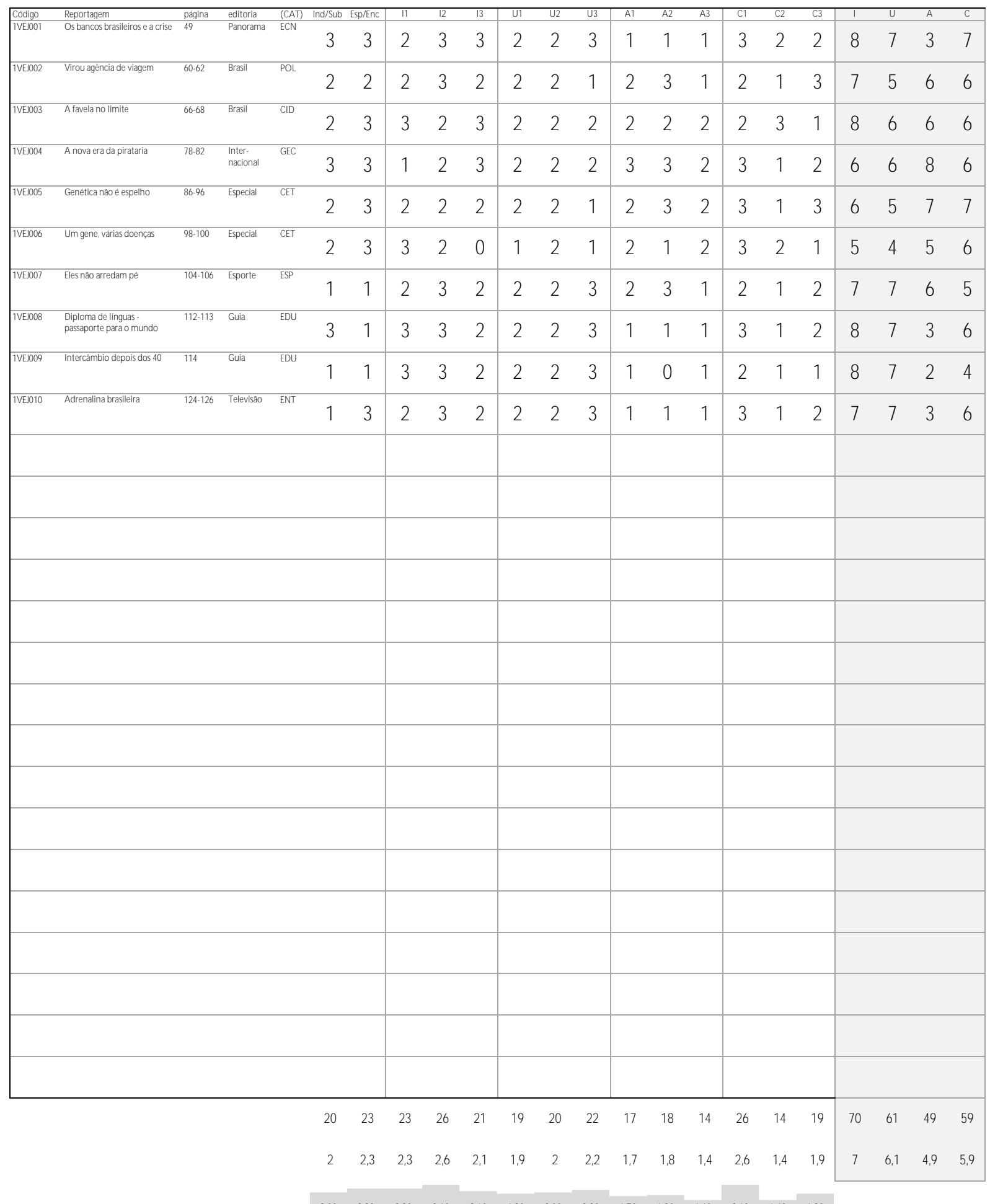




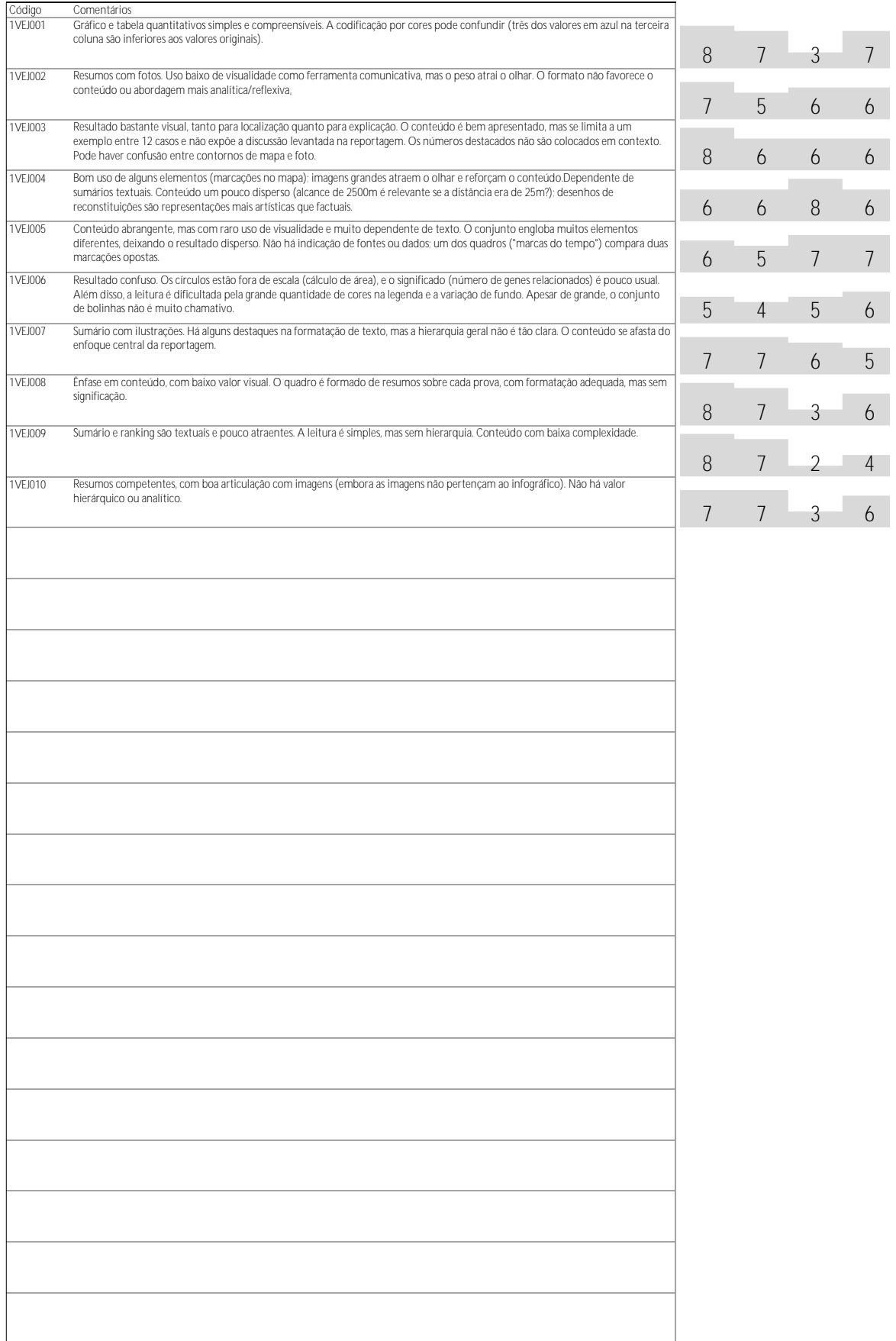


Veja, 28/out./2009 (2VEJ)

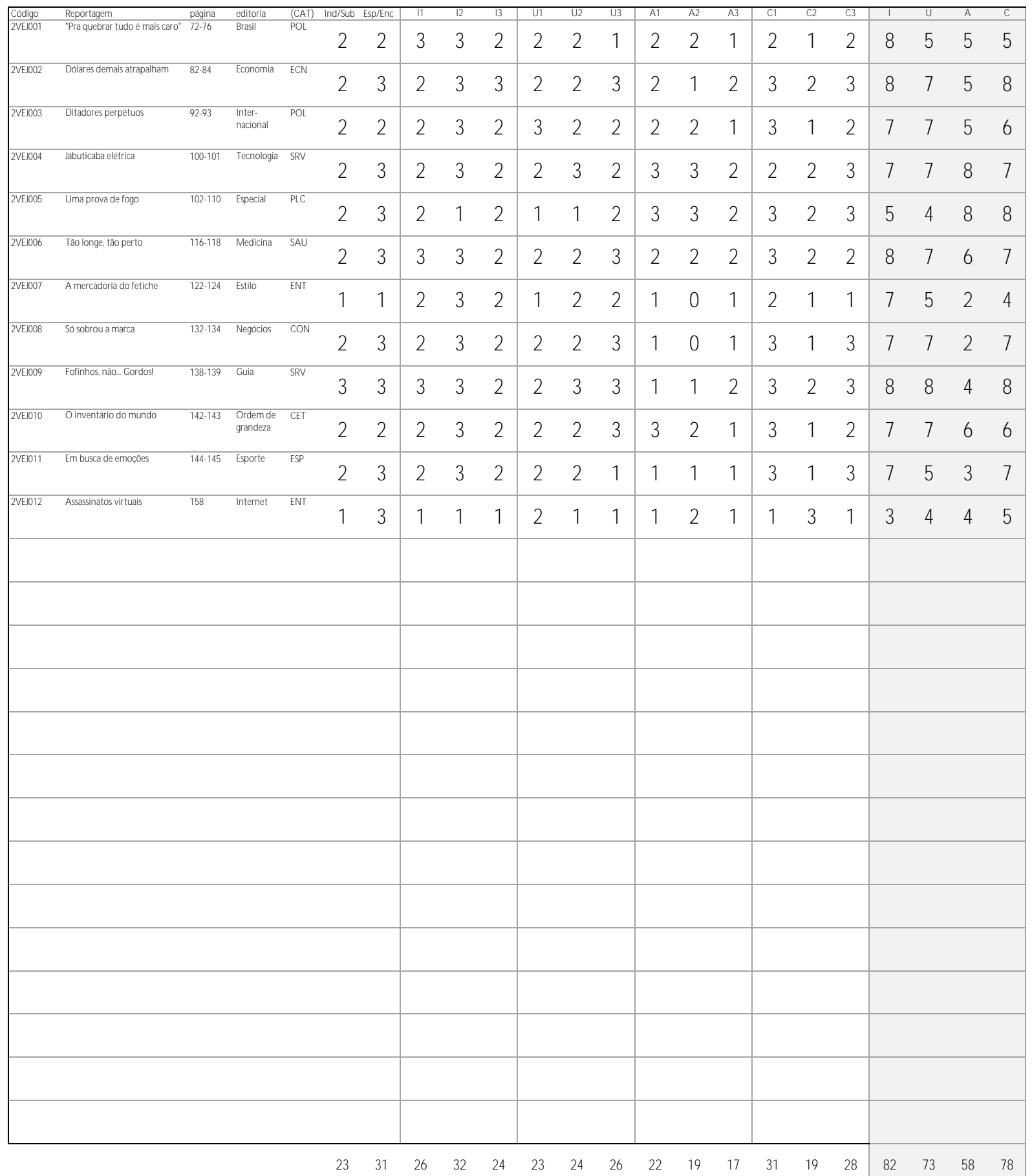

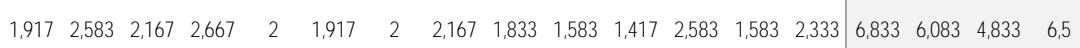

$\begin{array}{llllllllllllll}1,92 & 2,58 & 2,17 & 2,67 & 2,00 & 1,92 & 2,00 & 2,17 & 1,83 & 1,58 & 1,42 & 2,58 & 1,58 & 2,33\end{array}$ 


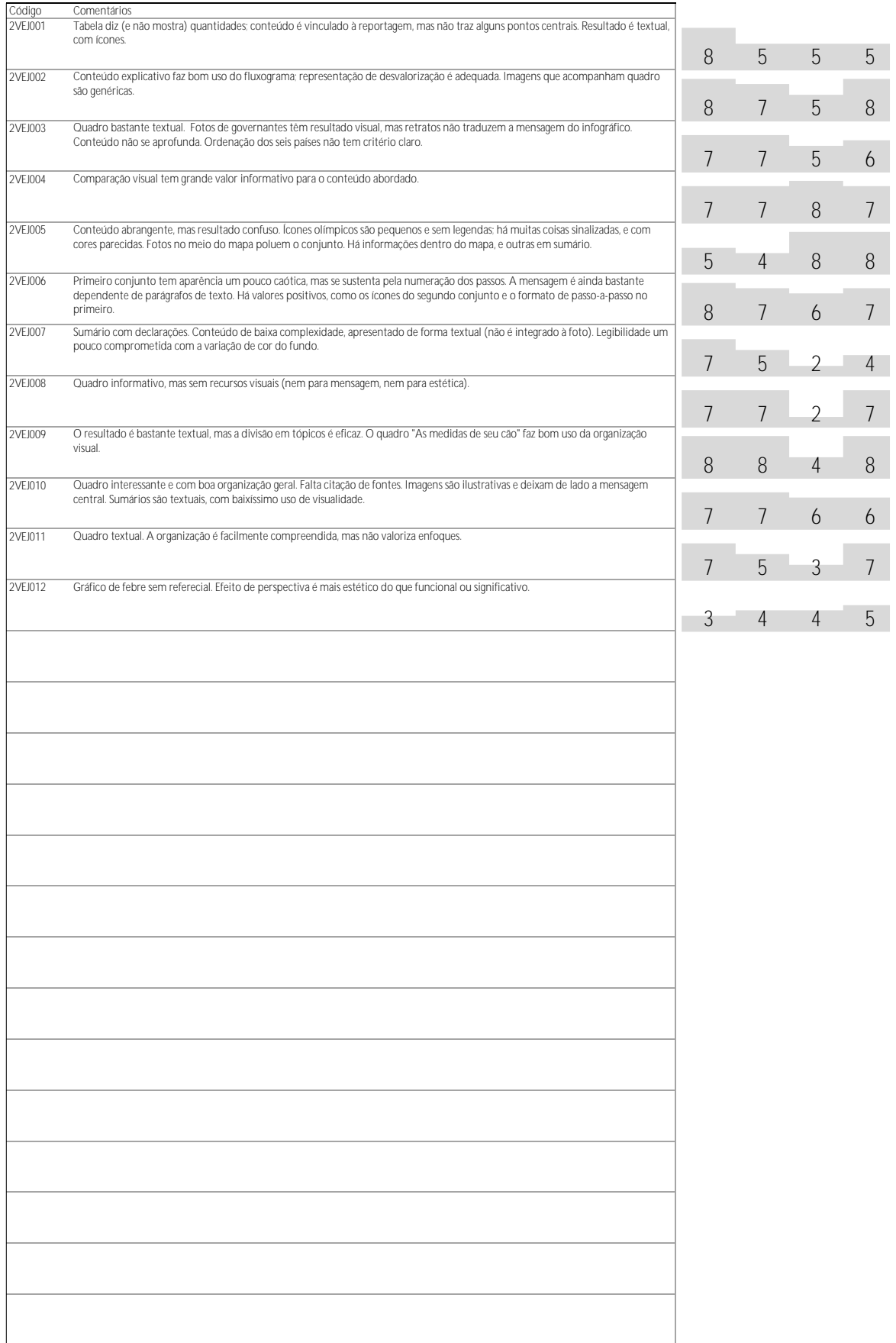


Veja, 21/abr./2010 (3VEJ)

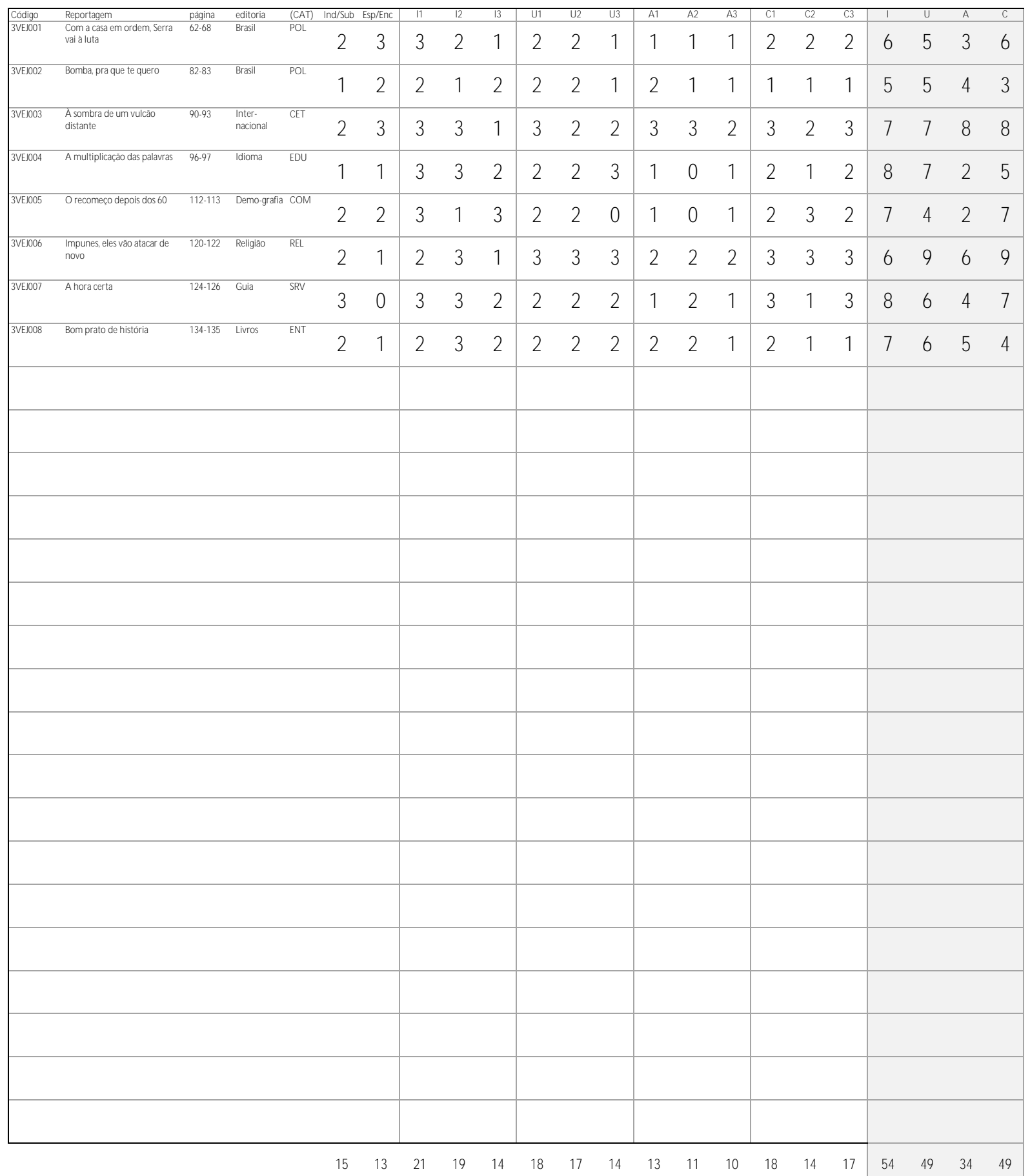

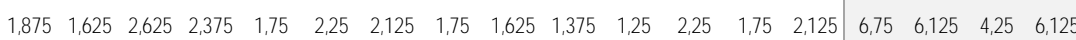




\begin{tabular}{|c|c|}
\hline $\begin{array}{l}\text { Código } \\
\text { उVEfJ001 }\end{array}$ & 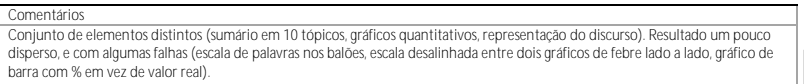 \\
\hline 3VE5002 & Declaraçäese estăo organizadas de forma confusaa (tem uma de 1975 no meio); missil é pouco visivel. \\
\hline 3VE5003 & 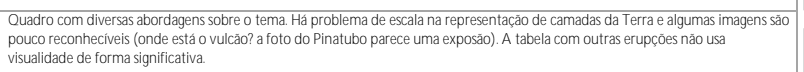 \\
\hline 3VE0004 & Vocabulário em texto, com uso quase nulo de recursos visisais. O conteúdo tem interesse paralelo à reportagem. \\
\hline 3VED005 & 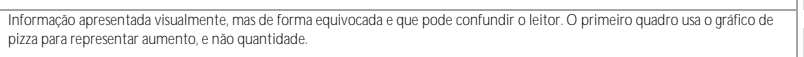 \\
\hline 3VE5006 & Uso interessante de simbolos se cores. \\
\hline 3VE5007 & Conteído composto em itens. As simagens ajudam a representar algumas passogens, maso conjunto é bastante textual. \\
\hline 3VE0008 & Quadro textual com algumasimagens. 0 conteúdo traz a seçăo "iliçāo". \\
\hline & \\
\hline & \\
\hline & \\
\hline & \\
\hline & \\
\hline & \\
\hline & \\
\hline & \\
\hline & \\
\hline & \\
\hline & \\
\hline & \\
\hline & \\
\hline & \\
\hline & \\
\hline & \\
\hline & \\
\hline & \\
\hline & \\
\hline
\end{tabular}

\begin{tabular}{|c|c|c|c|}
\hline 6 & 5 & 3 & 6 \\
\hline 5 & 5 & 4 & 3 \\
\hline 7 & 7 & 8 & 8 \\
\hline 8 & 7 & 2 & 5 \\
\hline 7 & 4 & 2 & 7 \\
\hline 6 & 9 & 6 & 9 \\
\hline 8 & 6 & 4 & 7 \\
\hline 7 & 6 & 5 & 4 \\
\hline
\end{tabular}


